FLAVIA RODRIGUES DE SOUZA

\title{
IMPLEMENTAÇÃO DE MODELO DE GESTÃO PARA EMPRESAS DE PROJETO DE EDIFÍCIOS
}

Dissertação apresentada à Escola Politécnica da Universidade de São Paulo para obtenção do título de Mestre em Engenharia. 
FLAVIA RODRIGUES DE SOUZA

\title{
IMPLEMENTAÇÃO DE MODELO DE GESTÃO PARA EMPRESAS DE PROJETO DE EDIFÍCIOS
}

\author{
Dissertação apresentada à Escola Politécnica \\ da Universidade de São Paulo para obtenção \\ do título de Mestre em Engenharia. \\ Área de Concentração: Engenharia de \\ Construção Civil \\ Orientador:
}

Prof. Livre-Docente Silvio Burrattino Melhado 
Este exemplar foi revisado e alterado em relação à versão original, sob responsabilidade única do autor e com a anuência de seu orientador.

São Paulo, de junho de 2009.

Assinatura do autor

Assinatura do orientador

FICHA CATALOGRÁFICA

Souza, Flavia Rodrigues de

Implementação de modelo de gestão para empresas de pro jeto de edifícios / F.R. de Souza. -- ed.rev. -- São Paulo, 2009.

$202 \mathrm{p}$.

Dissertação (Mestrado) - Escola Politécnica da Universidade de São Paulo. Departamento de Engenharia de Construção Civil.

1. Edifícios (Projeto) 2. Construção civil I. Universidade de São Paulo. Escola Politécnica. Departamento de Engenharia de Construção Civil II. t. 

Dedico esse trabalho à minha mãe Lisete Avelino de Souza e ao meu irmão Marco Antonio Rodrigues de Souza, responsáveis pelas melhores lembranças da minha vida. Certamente nos encontraremos novamente quando o "Segundo Sol Chegar". 


\section{AGRADECIMENTOS}

Agradeço ao Departamento de Engenharia de Construção Civil, em especial ao Professor Silvio Burrattino Melhado pela oportunidade de, através do desenvolvimento desta pesquisa, possibilitar-me inestimável desenvolvimento pessoal, profissional e acadêmico. Muitíssimo obrigada pela paciência, generosidade e amizade, e principalmente pelos exemplos de conduta ética para com seus alunos, pares e todos que o cercam.

Agradeço à minha mãe, onde quer que ela esteja, pois a realização deste trabalho somente foi possível em função da educação, formação e exemplos de vida, força e determinação por ela proporcionados. Agradeço por todo amor dedicado, pela sua franqueza, pelo seu inquestionável apoio às escolhas que fiz durante a minha caminhada, pelos conselhos, por me ensinar a decidir sem temer os resultados, de forma a arcar com as consequências, sendo elas boas ou ruins. Obrigada pelos inúmeros exemplos de honestidade e humildade, e por me mostrar que essa é a única maneira de viver bem, em paz e em harmonia com quem amamos e respeitamos. Mãe, muito obrigada principalmente por ter me ensinado a viver plenamente feliz e em paz, mesmo sem ter você ao meu lado.

Agradeço ao meu irmão Marco, meu grande amigo, protetor e companheiro, pois foi ele o responsável pela minha inscrição no processo de seleção. Tato, foram muitos os exemplos que você me deu ao longo de sua vida, mas o amor incondicional à nossa família e a sua intensa força para viver e lutar são os mais marcantes. Agradeço a você por ter me ensinado que a vida é linda, apesar de não sabermos até onde ela vai chegar, e por ter me ensinado a olhar para o céu todas as manhãs e agradecer a Deus por mais um dia de vida.

À minha irmã Silvana, ao meu irmão Esdras e às minhas lindas Maria Luiza e Gleyce, pela amizade, pela força e pela compreensão nos inúmeros momentos de ausência. Vocês são fonte de inspiração e força! Vana, minha irmã e melhor amiga, obrigada pelas conversas, troca de idéias, por sua visão crítica, pelo seu exemplo de disciplina e organização, tão importantes para um ser confuso como eu. Agradeço pelo seu incondicional apoio nos momentos difíceis, pelas sua broncas e por você gostar tanto de mim, apesar de eu ser, só às vezes, um "pouquinho chata". Eda, você é um exemplo de vida e conduta para as pessoas "perfeitinhas". Quando 
crescer, quero ser determinada e simpática como você, quero conquistar o mundo e todos a minha volta como você faz. Obrigada pelo carinho.

Agradeço ao meu pai por sempre financiar meus estudos e me apoiar nas decisões tomadas. Malu e Gleyce, minhas lindas sobrinhas, agradeço à Deus todos os dias por vocês existirem!

Agradeço ao melhor companheiro que a vida me deu, Abel. Sem a sua força, apoio, paciência e amor, minha vida seria muito sem graça. Você tem me proporcionado o melhor da vida.

Às empresas participantes do Programa de Desenvolvimento Gerencial, muitíssimo obrigada pela oportunidade de trabalharmos juntos, pela confiança e pelo pronto atendimento às nossas diversas solicitações durante a pesquisa.

Às meninas "super poderosas", Mariana e Melissa, agradeço pela constante predisposição em colaborar e contribuir para o trabalho. Obrigada pela alegria, pelos sorrisos, pela coragem; estes foram ingredientes fundamentais para a eficácia do nosso trabalho. Com certeza, a chegada da Fernanda, Marcello, Pamela e Ivanisi é resultado do alto astral do nosso grupo, que acaba contagiando todos à nossa volta. Meninas, obrigada pela amizade e carinho dedicado em momentos especialmente difíceis.

Com muito carinho, agradeço aos colegas da pós-graduação Jamilsito, Ricardito, Renatito, Rodrigo Gaúcho, Karen Maneschi, Leonardo Manzioni, Vivi, Adriana, Claudio, Cristiano Marques, Fernando Montija, Claudino; aos recém-chegados, mas igualmente carinhosos durante o final do percurso, Camila e Felipe, e para não ser injusta, agradeço também à todos aqueles que eu não citei. 


\section{RESUMO}

Sendo o setor da construção civil caracterizado historicamente por períodos de oscilação de demanda produtiva, torna-se essencial às empresas que nele atuam a adequada flexibilidade proporcionada pelo preparo gerencial, visando a perenidade e atuação sustentada. Nesse contexto, as micro e pequenas empresas do setor são normalmente as mais vulneráveis aos períodos de baixa demanda produtiva, em especial as empresas de projeto, que são, em sua grande maioria, despreparadas gerencialmente, além de não serem estruturadas e organizadas estrategicamente para atuarem de forma pro-ativa.

Diante desse quadro, Oliveira (2005) propôs um modelo de gestão específico para as empresas de projeto de edifícios com orientações para a gestão dos seus principais processos e funções. Objetivando a implementação do modelo citado, formaram-se dois grupos consecutivos compostos por empresas de projeto atuantes na cidade de São Paulo. Este trabalho foi denominado Programa de Desenvolvimento Gerencial para Empresas de Projeto, cuja finalidade era, através de pesquisa-ação, facilitar a implementação do modelo de gestão nas empresas de projeto através de atividades dirigidas, visando o desenvolvimento sustentado por meio do autoconhecimento de suas potencialidades e limitações, conduzindo-as à maturidade empresarial e, consequentemente, ao adequado preparo e flexibilidade necessários tanto para os períodos de recessão, quanto para os períodos de alta demanda produtiva setorial.

Frente a esse panorama, desenvolveu-se a pesquisa referente à análise da aplicação do modelo de gestão para empresas de projeto sob dois enfoques: reação das empresas e resultados alcançados em função da implementação. Este trabalho objetiva, ainda, a partir da revisão bibliográfica e experiências vividas durante a implementação do modelo, propor recomendações para facilitar a aplicação dos conceitos de gestão contemplados pelo modelo.

Palavras Chave: gestão de empresas de projeto de edifícios, processo de projeto, construção civil 


\begin{abstract}
As the Brazilian Civil Construction sector has historically been characterized by periods of oscillation productive demand, the flexibility proposed by the management prepare is essential to the companies of the sector, viewing endurable and sustainable acting. In this context, civil construction micro companies are usually the most sensitive to the low productive demand periods, specially the design firms, since most of them are unprepared and, in addition, they are not strategically organized and structured to take preventive actions in their market.

Due to this scenario, Oliveira (2005) proposed a design building firms management model which contains instructions to manage their essential processes and functions. Aiming to implement the above model, two successive work groups were formed, composed by design firms working for the São Paulo civil construction market. This work was named Design Firms Management Developing Program and it viewed, through action research, to facilitate the management model implementation in the design firms through dynamic activities aimed at sustained development by their own potentialities and knowledge limitation, conducting them to a business maturity and consequently to organize them to act in recession periods and also in high productive demand periods.
\end{abstract}

In this context, this research was developed aiming to analyze the design firms reaction along the program and the results attained due to the management model implementation. Through the bibliographic review, this research views to propose recommendations to applicate the model management and its concepts.

Keywords: design building firms management, design process, civil construction 
1. INTRODUCÃO

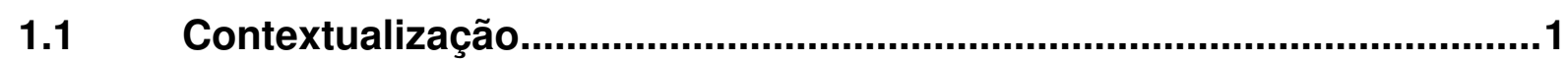

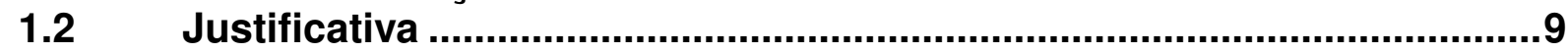

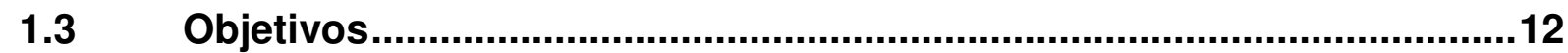

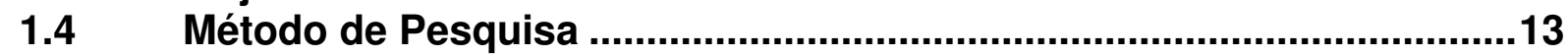

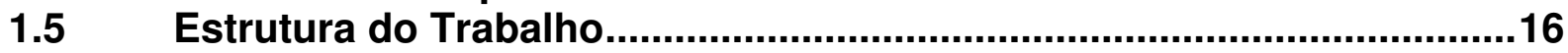

2. SISTEMA DE GESTÃO PARA EMPRESAS DE PROJETOS $\ldots \ldots \ldots \ldots \ldots \ldots \ldots \ldots 18$

2.1 Modelo de Gestão para Pequenas Empresas de Projeto de Edifícios .18

2.1.1 Preparação para Implementação do Modelo de Gestão ......................18

2.1.2 O Modelo de Gestão para Pequenas Empresas de Projeto de

\section{Edifícios 21}

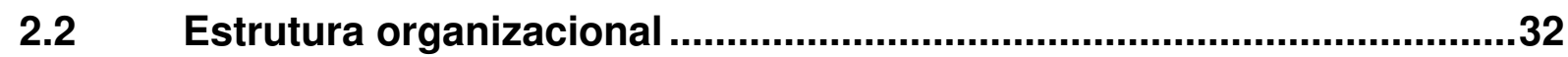

2.2.1 Organização através da estruturação...............................................33

2.2.2 Aspectos relevantes quanto à definição da estrutura organizacional 34

2.2.3 Tipos de Departamentalização...............................................................36

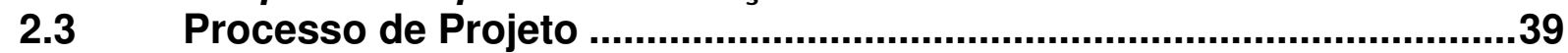

2.3.1 O processo de projeto no contexto da empresa ...............................41

2.3.2 Os princípios da administração de projetos........................................43

2.3.2.1 Plano do Projeto ........................................................................4

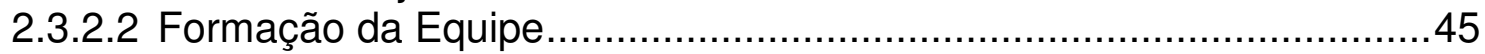

2.3.2.3 Estrutura do Projeto ...............................................................47

2.3.2.4 Planejamento do projeto: composição orçamentária, tempo e alocação de recursos ..................................................................................... 48

2.3.2.5 Planejamento da Comunicação, tratamento da informação, qualidade e controle do processo de projeto .....................................................................50

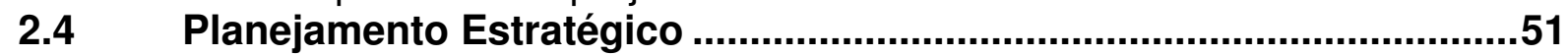

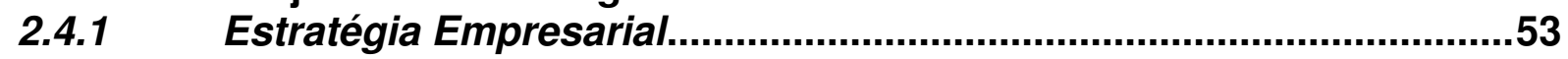

2.4.2 Vantagem competitiva ..............................................................56

2.4.3 Operacionalização do Planejamento Estratégico................................58

2.5 Gestão financeira ...........................................................................61

2.5.1 Organização e Demonstrações Financeiras ......................................62

2.5.2 Processo de Planejamento Financeiro............................................66

2.6 Sistema de informação e gestão do conhecimento.............................67

2.6.1 O papel da informação nas empresas..............................................70

2.7 Gestão Comercial e Marketing...........................................................73

2.7.1 Caracterização do Mercado..............................................................

2.7.2 Estratégia de Produto .......................................................................

2.7.3 Estratégia de Marketing, comunicação e venda pessoal....................79

2.7.4 Planejamento de Marketing ...................................................................

$2.8 \quad$ Gestão de Pessoas .........................................................................

2.8.1 Processo de provisão de pessoas para a organização .......................83

2.8.2 Aplicação, monitoração e manutenção das pessoas na organização 86 


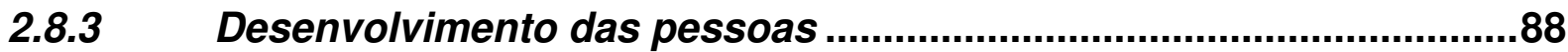

2.8.3.1 Aspectos comportamentais relacionados a gestão de pessoas ...............89

2.9 Gestão por Desempenho....................................................................91

2.9.1 Administração por desempenho como método ...............................92

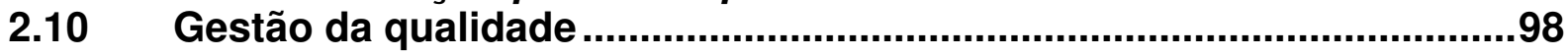

3. PESQUISA- ACÃO JUNTO ÀS EMPRESAS DE PROJETO

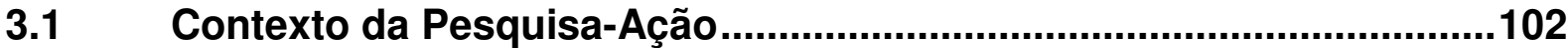

3.2 Sistematização do Trabalho durante a Pesquisa-Ação ......................104

3.3 Programa de Desenvolvimento Gerencial para Empresas de Projeto:

Etapa da Implementação do Modelo de Gestão ................................................107

3.4 Análise da Aplicação do Modelo de Gestão: Reações das empresas na

aplicação do modelo...................................................................................116

3.5 Análise da Aplicação do Modelo de Gestão: Resultados alcançados

pelas empresas em função da implementação do modelo de gestão...............132

4. PROPOSIC̄̃O DE RECOMENDACÕES PARA FACILITAR A APLICACÃO DOS CONCEITOS DE GESTÃO ÁS EMPRESAS DE PROJETO _....................145

4.1 Recomendações para aplicação dos conceitos sobre estrutura organizacional às empresas de projeto de edifícios.

4.2 Recomendações para aplicação dos conceitos de gestão de projetos à gestão do processo de projeto de edifícios......................................................148

4.3 Recomendações para a aplicação dos conceitos sobre planejamento

estratégico às empresas de projeto de edifícios...............................................151

4.4 Recomendações para aplicação dos conceitos sobre gestão financeira às empresas de projeto de edifícios.

4.5 Recomendações para aplicação dos conceitos abordados em sistemas de informação e comunicação às empresas de projeto de edifícios158 4.6 Recomendações para aplicação dos conceitos abordados sobre gestão comercial e marketing às empresas de projeto de edifícios .................160 4.7 Recomendações para aplicação dos conceitos abordados sobre gestão de pessoas às empresas de projeto de edifícios...................................162 4.8 Recomendações para aplicação dos conceitos abordados sobre gestão por desempenho às empresas de projeto de edifícios ..........................165 4.9 Recomendações para aplicação da gestão por desempenho ao processo de projeto ..............................................................................167

4.10 Recomendações para implementação de Sistema e Gestão da Qualidade na empresa de projeto

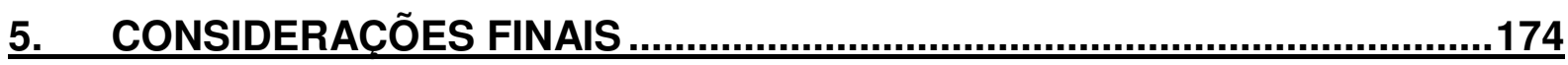

5.1 Quanto aos objetivos e limitações do trabalho..................................174

5.2 Quanto à pesquisa-ação junto às empresas de projeto ......................177

5.3 Quanto ao programa de desenvolvimento gerencial para empresas de projeto, análises sobre a aplicação do modelo de gestão e recomendações para facilitar a sua implementação 


\section{LISTA DE FIGURAS}

Figura 1.1 - Segmentação da Cadeia Produtiva da Construção. Fonte: Proposta de política industrial para a Construção Civil - Edificações, DECONCIC (2008) 2

Figura 1.2 - Participação de cada um dos segmentos da cadeia produtiva da Construção Civil. Fonte: $7^{\circ}$ Seminário da Indústria Brasileira da Construção (2008).

Figura 1.3 - Crescimento do Produto Interno Bruto do setor da Construção Civil, de 1991 até 2007.

Fonte: Proposta de política industrial para Construção Civil - Edificações, DECONCIC (2008)

Figura 1.4 - Encaminhamento genérico das etapas de pesquisa. 14

Figura 2.1 - O papel da estrutura organizacional no sistema de gestão da empresas.

Figura 2.2 - Métodos para elaboração da composição orçamentária de um projeto, segundo Meredith e Mantel Jr. (2003)

Figura 2.4 - Similaridades entre o processo de tomada de decisão e o processo de planejamento, segundo Bateman e Snell (1998)

Figura 2.5 - Esquema adaptado do processo de administração estratégica, de acordo com Thompson, Strickland (2001) e Fischman, Almeida (1991) .

Figura 2.6 - Componentes da Estratégia Empresarial, adaptado de Thompson, Strickland (2001).

Figura 2.7 - Fatores relevantes para análise interna e externa, de acordo com Bateman e Snell (1998)

Figura 2.8 - Visão esquemática de um sistema de informação, adaptado de Turban; McLean; Wetherbe (2004). 68

Figura 2.9 - Processamento de dados em informação e em conhecimento, de acordo com Turban; McLean; Wetherbe (2004) .72

Figura 4.1 - Cadeia de valores genérica para empresas de projeto composta por atividades primárias e atividades de apoio, de acordo com os conceitos estabelecidos por Porter (2004) 152

Figura 4.2 - Macroambiente e ambiente competitivo no qual as empresas de projeto estão imersas 154 


\section{LISTA DE TABELAS}

Tabela 1.1: Artigos publicados no Encontro Nacional de Tecnologia do Ambiente Construído de 1995 até 2006, sobre o tema "Processo de Projeto" ...5

Tabela 1.2: Artigos publicados no Workshop Brasileiro de Gestão do Processo de Projeto de 2001 até 2007

Tabela 1.3: Artigos publicados no Workshop Brasileiro de Gestão do Processo de Projeto de 2001 até 2007.

Tabela 2.1: Modelo de gestão para pequenas empresas de projeto de edifícios

Tabela 2.2: Modelo de gestão para pequenas empresas de projeto de edifícios

Tabela 2.3: Modelo de gestão para pequenas empresas de projeto de edifícios

Tabela 2.4: Modelo de gestão para pequenas empresas de projeto de edifícios

Tabela 2.5: Modelo de gestão para pequenas empresas de projeto de edifícios

Tabela 2.6: Modelo de gestão para pequenas empresas de projeto de edifícios

Tabela 2.7: Modelo de gestão para pequenas empresas de projeto de edifícios

Tabela 2.8: Modelo de gestão para pequenas empresas de projeto de edifícios

Tabela 2.9: Modelo de gestão para pequenas empresas de projeto de edifícios

Tabela 2.10: Fatores contingenciais a serem analisados para definição da estrutura organizacional.

Tabela 2.11: Tipos de departamentalização, segundo Maximiano (2004)

Tabela 2.12 : Características essenciais para o líder de projeto segundo Meredith e MantelJr. (2003), leitz e Rea (2001), Chen r Paitinghton (2006)

Tabela 2.13: Classificação proposta por Oliveira (1991) quanto às possíveis estratégias empresariais

Tabela 2.14: Importância dos demonstrativos financeiros, de acordo com Bodie; Merton (2002) e Longenecker, Moore, Petty (2004). 
Tabela 2.15 Tipos de sistema de informação, de acordo com Turban; McLean; Wetherbe (2004).

Tabela 2.16: Comportamento do comprador organizacional ,de acordo com Kotler e Armstrong (2003)

Tabela 2.17: Os cinco subprocessos básicos na Gestão de Pessoas, segundo Chiavenato (1999).

Tabela 2.18: Etapas do Recrutamento.

Tabela 2.19: Etapas do Método da Administração por Desempenho segundo Stoffel (1997): Planejamento

Tabela 2.20: Etapas do Método da Administração por Desempenho segundo Stoffel (1997): Acompanhamento do Desempenho

Tabela 2.21: Etapas do Método da Administração por Desempenho segundo Stoffel (1997): Avaliação do Desempenho

Tabela 2.22: Princípios a serem utilizados na implementação de um Sistema de Gestão da Qualidade, segundo a NBR ISO 9000:200

Tabela 3.1: Perfil das empresas participantes do PDGEP 1 de Empresas de Projeto

Tabela 3.2: Perfil das empresas participantes do PDGEP 2 de Empresas de Projeto

Tabela 3.3: Práticas de gestão das Empresas antes da participação no PDGEP 1 e PDGEP 2.

Tabela 3.4: Resumo das atividades desenvolvidas durante o PDGEP 1 e PDGEP 2

Tabela 3.5: Resumo do desenvolvimento de atividades de cada uma das empresas durante PDGEP 1

Tabela 3.6: Resumo do desenvolvimento de atividades de cada uma das empresas durante PDGEP 2

Tabela 3.7: Organização adotada pelas empresas durante o PDGEP 1

Tabela 3.8: Sistemática de trabalho adotada pelas empresas durante o PDGEP 2.

Tabela 3.9: Resumo das dificuldades específicas das empresas no desenvolvimento das tarefas referentes a cada um dos módulos durante o PDGEP 1 e PDGEP 2. 
Tabela 3.10 - Continuidade do desenvolvimento gerencial referente a cada um dos elementos do modelo de gestão proposto por Oliveira (2005) - PDGEP 1

Tabela 3.11 - Continuidade do desenvolvimento gerencial referente a cada um dos elementos do modelo de gestão proposto por Oliveira (2005) - PDGEP 2

Tabela 4.1: Recomendações para elaboração de uma plano geral para gestão do processo de projeto.

Tabela 4.2: Recomendações para aplicação da gestão por desempenho em empresas de projeto

Tabela 4.3: Recomendações para análises de desempenho durante o Processo de Projeto segundo Melhado et al (2005) na empresa de projeto

Tabela 4.4: Avaliação de desempenho durante o Processo de Projeto segundo Melhado et al (2005) as quais a empresas de projeto estarão sujeitas 


\section{LISTA DE ABREVIATURAS}

ABAP

ABECE

ABRASIP

ABRASIP

ABRAVA

ABRIESP

AGESC

$A Q C$

AsBEA

COMCIC

CIB

CTE

DECONCIC

EAP

EMBRAESP

ENTAC

FIESP

MERCOSUL

NUTAU

PBQP-H
Associação Brasileira de Paisagismo

Associação Brasileira de Engenharia e Consultoria Estrutural

Associação Brasileira de Engenharia de Sistemas Prediais

Associação Brasileira de Engenharia de Sistemas Prediais

Associação Brasileira de Refrigeração, Ar Condicionado, Ventilação e Aquecimento

Associação Brasileira da Indústria do Esporte

Associação Brasileira dos Gestores e Coordenadores de Projeto

Agence Qualité Construction

Associação Brasileira dos Escritórios de Arquitetura

Comitê da Cadeia Produtiva da Industria da Construção Civil/ FIESP

International Council for Research and Innovation in Building and Construction

Centro de Tecnologia de Edificações

Departamento da Indústria da Construção

Estrutura Analítica de Projeto

Empresa Brasileira de Estudos de Patrimônio

Encontro Nacional de Tecnologias do Ambiente Construído

Federação das Indústrias dos Estado de São Paulo

Mercado Comum do Sul

Núcleo de Pesquisa em Tecnologia da Arquitetura e Urbanismo da Universidade de São Paulo

Programa Brasileiro de Qualidade e Produtividade do Habitat 
PDGEP

PMBOK

SINDUSCON-SP

SWOT

WBS
Programa de Desenvolvimento Gerencial para Empresas de Projeto

Project Management Body of Knowledge

Sindicato da Indústria da Construção Civil do Estado de São

Strengths, Weaknesses, Opportunities and Threats

Work Breakdown Structure 


\section{INTRODUÇÃO}

\section{$1.1 \quad$ Contextualização}

O DECONCIC - Departamento da Indústria da Construção (2008), da Federação das Indústrias do Estado de São Paulo, define a Construção Civil como um setor vasto e heterogêneo, caracterizado pela integração de uma série de atividades com diferentes graus de complexidade, ligadas entre si por uma ampla diversificação de produtos, com processos tecnológicos variados, vinculados a diferentes tipos de demandas. O setor abriga desde indústrias com tecnologia de ponta e capital intensivo, como cimento, siderurgia e química, até milhares de microempresas de serviços, sendo a maior parte com baixo conteúdo tecnológico.

Conforme demonstrado na Figura 1.1, Segmentação da cadeia produtiva da construção, a construção civil é dividida em cadeia produtiva de edificações e cadeia produtiva da construção pesada, que são compostas desde por indústrias de materiais de construção até empresas voltadas à comercialização das unidades edificadas e empresas responsáveis pela operação e manutenção das obras de construção pesada, sendo que as empresas de projeto são agentes que atendem tanto à cadeia de edificações quanto à de construção pesada. 


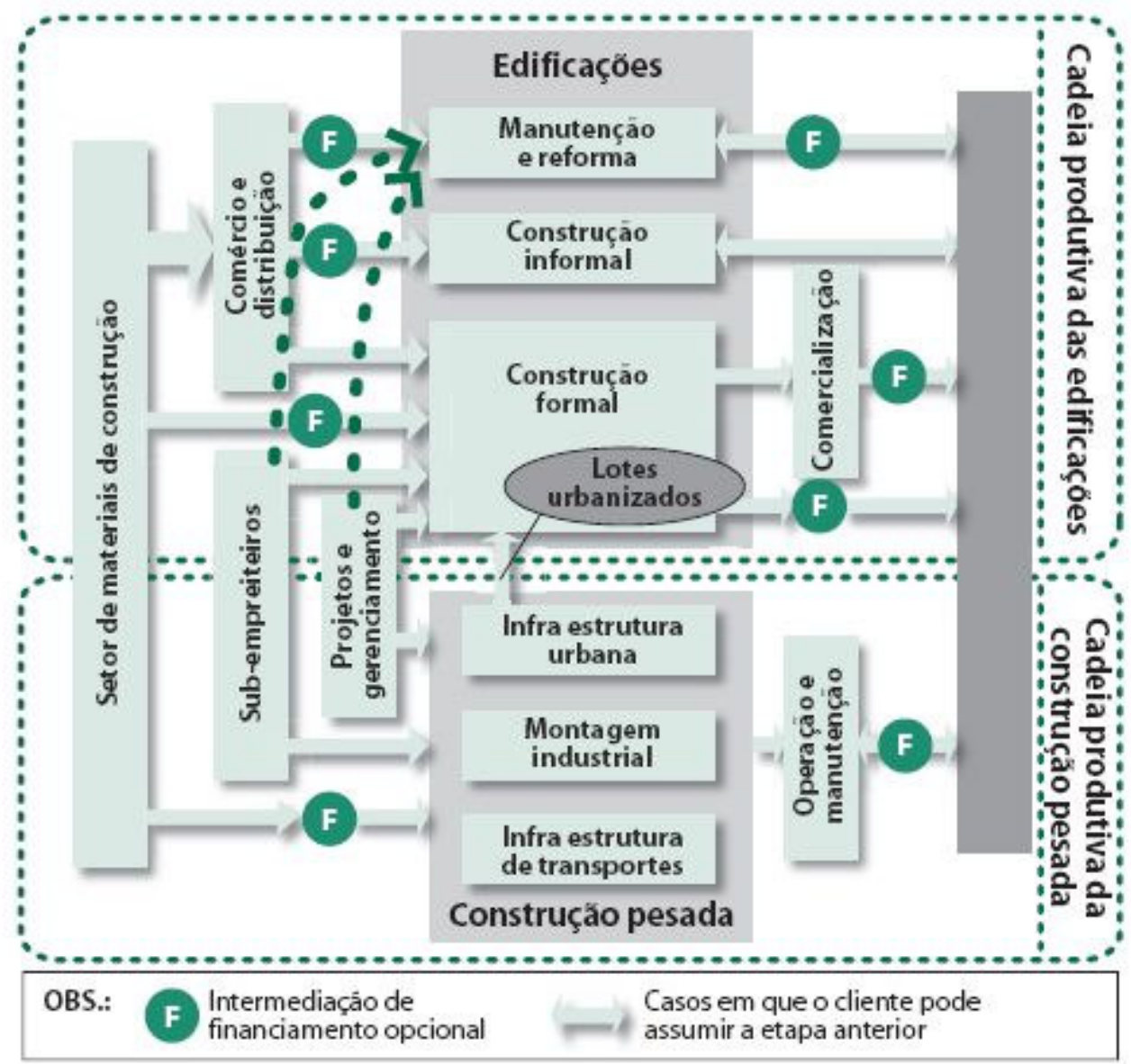

Figura 1.1 - Segmentação da Cadeia Produtiva da Construção. Fonte: Proposta de política industrial para a Construção Civil - Edificações, DECONCIC (2008)

De acordo com o documento, 105.469 empresas de construção civil atuavam no setor no ano de 2005. Dessas empresas, cerca de 93\% eram caracterizadas como micro e pequenas empresas, e 73\% atuavam no segmento de edificações e obras de engenharia civil.

Quanto a sua relevância em relação à produção industrial do país, de acordo com dados publicados pela FIESP (2008), o setor da Construção Civil contribuiu, em 2007, com 11,3\% no PIB brasileiro e, até setembro de 2008, foi responsável pela ocupação de 8,2 milhões de trabalhadores (diretos e indiretos), dos quais cerca de $29 \%$ são formais e $71 \%$ informais.

Verifica-se através da Figura 1.2, Participação de cada um dos segmentos da cadeia produtiva da construção civil, que embora os serviços - incluindo projetos, tenham apenas $0,5 \%$ de participação no PIB, a atividade projetual interfere 
diretamente em todos os segmentos da indústria da construção civil; logo, as discussões referentes ao seu desenvolvimento são estratégicas para o setor.
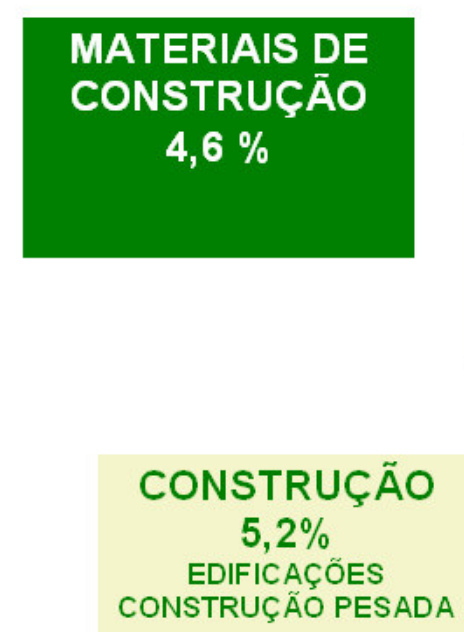

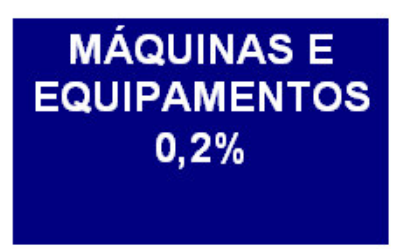

OUTROS

MATERIAIS

$0,8 \%$ 


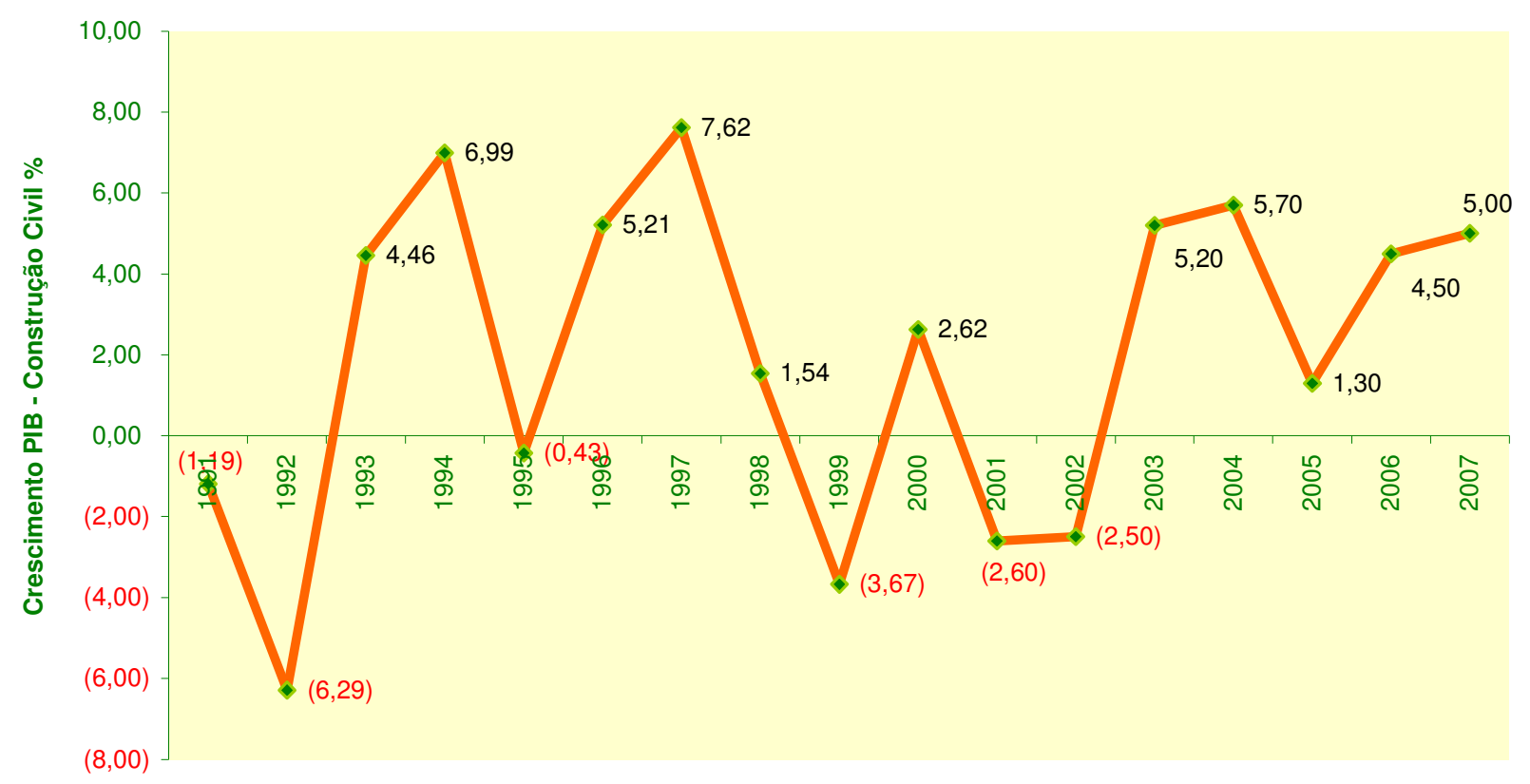

Figura 1.3 - Crescimento do Produto Interno Bruto do setor da Construção Civil, de 1991 até 2007.

Fonte: Proposta de política industrial para Construção Civil - Edificações, DECONCIC (2008) Historicamente, as empresas de projeto colocam-se na posição de "elo fraco" da cadeia produtiva da construção civil, em função da escassez de recursos ocasionada pela baixa remuneração dos projetos. Além disso, no contexto atual, em função das mudanças mencionadas, os contratantes tendem a ser mais exigentes e, portanto, mais seletivos em relação à capacidade técnica, produtiva e gerencial de seus fornecedores. Isso vale, inclusive, para as empresas de projeto, principalmente quanto à flexibilidade na adaptação e resposta aos momentos de baixa demanda.

Nesse sentido, a melhor resposta a ser dada aos "momentos de crise" consiste na busca pela reestruturação gerencial visando o desenvolvimento sustentado através do conhecimento de suas potencialidades, independentemente do tamanho e dos recursos de que dispõem.

Além da contextualização setorial, é importante compreender como o tema "gestão das empresas de projeto" tem sido abordado academicamente no Brasil. Para tanto, foram pesquisados os artigos publicados na linha de pesquisa do Processo de Projetos desde 1995 até 2007 nos eventos nacionais mais representativos para a área: ENTAC - Encontro Nacional de Tecnologia do Ambiente Construído, e Workshop Brasileiro de Gestão do Processo de Projeto. 
A contextualização acadêmica objetiva mostrar, tanto quantitativa quanto qualitativamente, a produção científica voltada para o tema "Gestão de Empresas de Projeto de Edifícios".

Análise quantitativa enfoca a comparação entre o número de artigos publicados sobre o tema "Gestão das Empresas de Projeto" e os demais temas da linha de pesquisa : informações iniciais para o processo de projeto; sustentabilidade voltada para o desenvolvimento de projetos; gestão do processo de projeto; processo de projeto; qualidade do processo de projeto; tecnologia da informação aplicada ao processo de projeto; interface entre projeto e o processo de construção e pósocupação.

Para tanto, Conforme as Tabelas 1.2 e 1.3, e de acordo com Souza e Melhado (2008), diversos artigos têm sido publicados sobre o tema processo de projeto desde 1995. No entanto, em termos quantitativos, se compararmos o número de trabalhos publicados sobre o tema "Gestão das Empresas de Projeto" com relação aos demais, verifica-se que, academicamente, o assunto ainda é pouco explorado.

Tabela 1.1: Artigos publicados no Encontro Nacional de Tecnologia do Ambiente Construído de 1995 até 2006, sobre o tema "Processo de Projeto"

\begin{tabular}{|c|c|c|c|c|c|c|}
\hline Tema & 1995 & 1998 & 2000 & 2002 & 2004 & 2006 \\
\hline $\begin{array}{l}\text { Informações iniciais para o processo } \\
\text { de projeto }\end{array}$ & 2 & 2 & 8 & 9 & 5 & 7 \\
\hline $\begin{array}{l}\text { Sustentabilidade voltada para } \circ \\
\text { desenvolvimento de projetos }\end{array}$ & 0 & 0 & 1 & 1 & 2 & 2 \\
\hline Gestão do processo de projeto & 3 & 0 & 2 & 5 & 7 & 7 \\
\hline Processo de projeto & 1 & 5 & 1 & 3 & 5 & 5 \\
\hline Qualidade do processo de projeto & 3 & 2 & 5 & 1 & 0 & 0 \\
\hline $\begin{array}{l}\text { Tecnologia da informação aplicada ao } \\
\text { processo de projeto }\end{array}$ & 1 & 1 & 1 & 2 & 8 & 7 \\
\hline $\begin{array}{l}\text { Interface entre projeto e processo de } \\
\text { construção }\end{array}$ & 3 & 11 & 3 & 4 & 3 & 3 \\
\hline Pós-ocupação & 8 & 8 & 7 & 5 & 3 & 13 \\
\hline Gestão das empresas de projeto & 0 & 2 & 0 & 1 & 2 & 1 \\
\hline TOTAL & 21 & 31 & 28 & 31 & 35 & 45 \\
\hline
\end{tabular}


Tabela 1.2: Artigos publicados no Workshop Brasileiro de Gestão do Processo de Projeto de 2001 até 2007

\begin{tabular}{|c|c|c|c|c|c|c|}
\hline Tema & 2001 & 2002 & 2003 & 2004 & 2005 & 2007 \\
\hline $\begin{array}{l}\text { Informações iniciais para o processo } \\
\text { de projeto }\end{array}$ & 0 & 5 & 3 & 8 & 5 & 10 \\
\hline $\begin{array}{l}\text { Sustentabilidade voltada para } 0 \\
\text { desenvolvimento de projetos }\end{array}$ & 0 & 1 & 2 & 2 & 2 & 5 \\
\hline Gestão do processo de projeto & 7 & 4 & 6 & 7 & 9 & 8 \\
\hline Processo de projeto & 1 & 5 & 6 & 10 & 7 & 0 \\
\hline Qualidade do processo de projeto & 4 & 2 & 3 & 7 & 4 & 2 \\
\hline $\begin{array}{l}\text { Tecnologia da informação aplicado ao } \\
\text { processo de projeto }\end{array}$ & 4 & 10 & 11 & 8 & 6 & 14 \\
\hline $\begin{array}{l}\text { Interface entre projeto e processo de } \\
\text { construção }\end{array}$ & 12 & 8 & 9 & 9 & 7 & 5 \\
\hline Pós-ocupação & 2 & 0 & 5 & 2 & 2 & 4 \\
\hline Gestão das empresas de projeto & 3 & 1 & 8 & 3 & 8 & 2 \\
\hline TOTAL & 33 & 36 & 53 & 56 & 50 & 50 \\
\hline
\end{tabular}

Quanto à análise qualitativa referente aos artigos publicado na linha de pesquisa do processo de projeto, enfoca somente os trabalhos publicados sobre o tema Gestão das Empresas de Projeto, conforme mostra a Tabela 1.3. De modo geral, de acordo com Souza e Melhado (2008), os artigos sobre esse tema enfocam os seguintes aspectos:

- A organização do "escritório de projeto" através da tecnologia da informação.

- Sistemas de gestão da qualidade nas empresas de projeto.

- Sistema de Informação para a gestão da empresa de projeto.

- Gestão por Desempenho aplicada às empresas e ao processo de projeto.

- Gestão de pessoas. 


\begin{tabular}{|c|c|c|c|}
\hline TÍTULO & AUTOR(ES) & ANO & ENFOQUE \\
\hline $\begin{array}{l}\text { Qualificação das empresas de projeto de } \\
\text { arquitetura }\end{array}$ & S. B. Melhado & 2001 & $\begin{array}{l}\text { Gestão da } \\
\text { Qualidade }\end{array}$ \\
\hline \begin{tabular}{|c|} 
Programas de Gestão da Qualidade em \\
escritórios de projeto: situação no Estado do Rio \\
Grande do Sul
\end{tabular} & M.M. Jobim & 2001 & $\begin{array}{l}\text { Gestão da } \\
\text { Qualidade }\end{array}$ \\
\hline $\begin{array}{c}\text { Análise da situação das empresas de projeto do } \\
\text { Estado do Ceará quanto à implantação de } \\
\text { sistemas da qualidade }\end{array}$ & $\begin{array}{l}\text { J.P. Nobre } \\
\text { J. P. Barros Neto }\end{array}$ & 2001 & $\begin{array}{l}\text { Gestão da } \\
\text { Qualidade }\end{array}$ \\
\hline $\begin{array}{l}\text { Implementação de gestấo da qualidade em } \\
\text { empresas de projeto }\end{array}$ & $\begin{array}{l}\text { Grilo, L. M.; Peña, M. D.; } \\
\text { Santos, L. A.; Filippi, G. }\end{array}$ & 2003 & $\begin{array}{l}\text { Gestão da } \\
\text { Qualidade }\end{array}$ \\
\hline $\begin{array}{c}\text { Certificação de Empresas de Projeto: um estudo } \\
\text { de caso }\end{array}$ & $\begin{array}{l}\text { P. R. P. Andery, } \\
\text { M. P. C. Lana, } \\
\text { G. Borges }\end{array}$ & 2002 & $\begin{array}{l}\text { Gestão da } \\
\text { Qualidade }\end{array}$ \\
\hline $\begin{array}{c}\text { Uma nova solução para a certificação de } \\
\text { sistemas de gestão da qualidade em empresas } \\
\text { de projeto }\end{array}$ & S.B. Melhado & 2003 & $\begin{array}{l}\text { Gestão da } \\
\text { Qualidade }\end{array}$ \\
\hline $\begin{array}{c}\text { A gestão de pessoas e a gestão do } \\
\text { conhecimento adquirindo papel fundamental na } \\
\text { gestão de projetos }\end{array}$ & F. B. M. Quintão & 2003 & $\begin{array}{l}\text { Gestão de } \\
\text { Pessoas }\end{array}$ \\
\hline $\begin{array}{l}\text { Uma metodologia para implantação de sistemas } \\
\text { de gestão da qualidade em escritórios de } \\
\text { projetos }\end{array}$ & $\begin{array}{l}\text { M. Fossatti } \\
\text { R. C. Nazário } \\
\text { H. R. Roman }\end{array}$ & 2003 & $\begin{array}{l}\text { Gestão da } \\
\text { Qualidade }\end{array}$ \\
\hline $\begin{array}{c}\text { Gestão do processo comercial na empresa de } \\
\text { projeto }\end{array}$ & $\begin{array}{l}\text { O. J. Oliveira } \\
\text { S. B. Melhado }\end{array}$ & 2003 & $\begin{array}{l}\text { Gestão } \\
\text { Comercial }\end{array}$ \\
\hline $\begin{array}{c}\text { Melhoria do Processo de Projeto de Escritório de } \\
\text { Arquitetura. Estudo de caso com ênfase na } \\
\text { gestão de recursos humanos. }\end{array}$ & $\begin{array}{l}\text { A. A. C. Menezes } \\
\text { R. A. Lopes } \\
\text { S. R. Leusin de Amorim }\end{array}$ & 2003 & $\begin{array}{l}\text { Gestão de } \\
\text { Pessoas }\end{array}$ \\
\hline $\begin{array}{l}\text { Implantação de Sistema de Gestão da } \\
\text { Qualidade em empresas de elaboração de } \\
\text { projetos }\end{array}$ & $\begin{array}{l}\text { J. L. S. Ribeiro } \\
\text { M. L. S. Costa }\end{array}$ & 2003 & $\begin{array}{l}\text { Gestão da } \\
\text { Qualidade }\end{array}$ \\
\hline $\begin{array}{c}\text { Considerações sobre a prática profissional do } \\
\text { arquiteto }\end{array}$ & F. Segnini & 2004 & $\begin{array}{l}\text { Gestão de } \\
\text { Pessoas }\end{array}$ \\
\hline $\begin{array}{l}\text { Avaliação de desempenho do projeto de } \\
\text { edificações junto às empresas construtoras }\end{array}$ & $\begin{array}{l}\text { O. J. Oliveira } \\
\text { S. B. Melhado }\end{array}$ & 2004 & $\begin{array}{l}\text { Gestão por } \\
\text { Desempenho }\end{array}$ \\
\hline $\begin{array}{l}\text { Um estudo exploratório em empresas baianas } \\
\text { sobre o relacionamento entre construtoras e } \\
\text { projetistas }\end{array}$ & L. C. C. Meira & 2004 & $\begin{array}{l}\text { Gestão } \\
\text { Comercial }\end{array}$ \\
\hline $\begin{array}{l}\text { Peculiaridades do fluxo de informaçóes em } \\
\text { pequenos escritórios de projetos de edificações }\end{array}$ & C. A. Jakoski & 2005 & $\begin{array}{l}\text { Sistema de } \\
\text { Informação }\end{array}$ \\
\hline $\begin{array}{l}\text { Impacto do Sistema de Garantia da Qualidade } \\
\text { em empresas de projeto sobre as suas } \\
\text { tecnologias da informacão }\end{array}$ & $\begin{array}{l}\text { P. R. P. Andery, } \\
\text { E. M. Arantes, } \\
\text { M. P. Vieira }\end{array}$ & 2005 & $\begin{array}{l}\text { Sistema de } \\
\text { Informação }\end{array}$ \\
\hline $\begin{array}{l}\text { Terceirização do escritório de projeto e da } \\
\text { gestão das aquisições na construção civil }\end{array}$ & A. A. Choma & 2005 & $\begin{array}{l}\text { Gestão de } \\
\text { Pessoas }\end{array}$ \\
\hline $\begin{array}{c}\text { Qualidade em serviços - Escritórios de pequeno } \\
\text { porte }\end{array}$ & $\begin{array}{l}\text { A. M. Lyrio Filho } \\
\text { S. R. Leusin de Amorim }\end{array}$ & 2005 & $\begin{array}{l}\text { Gestão da } \\
\text { Qualidade }\end{array}$ \\
\hline $\begin{array}{l}\text { Sistema de avaliação de desempenho para } \\
\text { projetos e empresas de projeto }\end{array}$ & $\begin{array}{l}\text { O. J. Oliveira } \\
\text { S. B. Melhado }\end{array}$ & 2005 & $\begin{array}{l}\text { Gestão por } \\
\text { Desempenho }\end{array}$ \\
\hline $\begin{array}{l}\text { A gestão de escritórios de projetos de } \\
\text { arquitetura na região do Rio de Janeiro } \\
\text { Continua na primeira }\end{array}$ & $\begin{array}{l}\text { R. F. M. Vasconcelos } \\
\text { S. R. Leusin de Amorim }\end{array}$ & 2005 & $\begin{array}{l}\text { Gestão da } \\
\text { Empresa de } \\
\text { Projeto }\end{array}$ \\
\hline
\end{tabular}




\begin{tabular}{|c|c|c|c|}
\hline TIITULO & AUTOR(ES) & ANO & ENFOQUE \\
\hline $\begin{array}{l}\text { O planejamento e custeio de projetos das } \\
\text { edificações e serviços técnicos para formação } \\
\text { de preço em escritório de projetos }\end{array}$ & $\begin{array}{l}\text { F. J. Cararo } \\
\text { S. A. C. Wille }\end{array}$ & 2006 & $\begin{array}{l}\text { Gestão } \\
\text { Comercial }\end{array}$ \\
\hline $\begin{array}{l}\text { Fluxograma de atividades para a formação de } \\
\text { preço de venda de projetos e serviços técnicos } \\
\text { para escritórios de arquitetura }\end{array}$ & $\begin{array}{l}\text { F. J. Cararo } \\
\text { S. A. C. Wille }\end{array}$ & 2006 & $\begin{array}{l}\text { Gestão } \\
\text { Comercial }\end{array}$ \\
\hline Modelos para gestão de empresas de projeto & S. B. Melhado & 2006 & $\begin{array}{l}\text { Gestão da } \\
\text { Empresa de } \\
\text { Projeto }\end{array}$ \\
\hline $\begin{array}{l}\text { A importância do sistema de informação para a } \\
\text { empresa de projeto }\end{array}$ & $\begin{array}{l}\text { F. R. Souza } \\
\text { S. B. Melhado }\end{array}$ & 2007 & $\begin{array}{l}\text { Sistema de } \\
\text { informação }\end{array}$ \\
\hline
\end{tabular}

Assim, se analisada a Tabela 1.3, os artigos publicados entre 2001 e 2007 enfocam, em sua maioria, o sistema de gestão da qualidade. Quanto aos trabalhos relacionados à gestão da empresa de projeto são direcionados, à exemplo dos artigos publicados sobre gestão comercial, gestão de pessoas, sistema de informação e gestão por desempenho.

Outro ponto interessante relacionado aos trabalhos publicados refere-se à especialidade das empresas sobre as quais foram realizadas as pesquisas, uma vez que a maior parte dos estudos de caso foram realizados em empresa de projeto de arquitetura.

O tema "Gestão da Empresa de Projeto" abordado de forma global, à exemplo dessa dissertação e do trabalho de Doutorado de Oliveira (2005), ainda é pouco explorando na linha de pesquisa. Logo, em virtude da escassez de trabalhos publicados e da influência direta do tema sobre as discussões voltadas ao desenvolvimento setorial, pesquisas sobre o assunto são necessárias, além do que, as possibilidades da exploração do tema são muito amplas. 
Tendo em vista a influência direta do setor da construção civil sobre o crescimento econômico do país, os programas voltados ao seu desenvolvimento têm ocupado espaço destacado nas agendas governamentais das últimas duas décadas. Como conseqüência, o mesmo tem ocorrido nas pautas de trabalho de instituições cujas atuações são atreladas ao setor, tais como Federações de Indústria de diversos estados, Sindicatos, Associações Representantes de Profissionais do Setor, Universidades, Instituições de Ensino e Aperfeiçoamento Profissional, entre outros.

Ao longo desse período, as mudanças estruturais, tecnológicas, produtivas e organizacionais ocorridas no setor têm afetado fortemente todos os agentes da cadeia produtiva da construção civil, inclusive as empresas de projeto, indicando a necessidade de disposição quanto à redefinição das formas de trabalho $\mathrm{e}$ relacionamentos vigentes até então.

Portanto, alinhado às iniciativas de desenvolvimento setorial em pauta, este trabalho justifica-se pela necessidade de organização das empresas de projeto, uma vez que as práticas usuais de gestão apontadas por Oliveira (2005), bem como as características gerais dessas empresas e suas deficiências estruturais são fortes indicadores da necessidade de desenvolvimento e aperfeiçoamento gerencial.

Quanto as práticas usuais de gestão listadas pelo autor, destacam-se:

- Estratégia: Falta de planejamento de suas ações e atuações a curto, médio e longo prazo.

- Estrutura Organizacional: Predomina a informalidade no tocante a atribuição de autoridade e responsabilidade, normalmente concentrando essas competências no profissional titular ou nos profissionais mais experientes da empresa.

- Gestão Comercial: Normalmente não são estabelecidos critérios para a determinação de preços dos serviços prestados, usualmente estabelecidos em função dos preços vigentes do mercado, ou até mesmo em função da experiência do profissional titular. 
- Gestão Financeira: Ocorrências rotineiras de desorganização das finanças das empresas de projeto, na maior parte dos casos, em função do baixo conhecimento de ferramentas e rotinas que possibilitem 0 adequado planejamento econômico e financeiro por parte dos seus gestores, bem como dos controles posteriores.

- Sistema de Informação: As empresas de projeto desconhecem ou subutilizam ferramentas que possibilitam a captação, o tratamento e disponibilização da informação, tanto durante o processo de projeto quanto do fluxo de informações inerentes à gestão da empresa.

- Gestão de Pessoas: Adotam rotinas informais e não planejadas na contratação e demissão de colaboradores, além de não estabelecerem planos de aperfeiçoamento profissional e remuneração. Sendo a terceirização prática corriqueira no segmento, as empresas normalmente não estabelecem critérios para seleção e contratação de seus prestadores, ou acompanhamento e recebimento dos serviços prestados.

Sobre as características gerais das empresas de projeto, destaca-se, entre outros, a escassez de recursos financeiros para investimentos em programas empresariais voltados ao aperfeiçoamento administrativo através de consultorias, principalmente para o desenvolvimento ou aquisição de ferramentas gerenciais.

Alinhada à escassez de recursos financeiros, predomina no segmento de projetos a carência de programas específicos para formação gerencial dos profissionais titulares das empresas de projeto (engenheiros, arquitetos e tecnólogos) a serem oferecidos durante a graduação, ou até mesmo como especialização, cujo objetivo seria o de prover conhecimentos e técnicas para melhor organizar e controlar as empresas de projeto, conduzindo-as, dessa forma, à competitividade.

Nesse sentido, Oliveira (2005) propôs o Modelo de Gestão para empresas de projeto, cujas aplicações ocorreram em dois grupos de trabalho consecutivos (Grupo 1: de abril de 2006 até maio de 2007, e Grupo 2: de setembro de 2007 até maio de 2008), formados por dezesseis empresas de projeto, que aceitaram participar dos grupos de forma voluntária. 
Em princípio, o trabalho foi denominado "Programa de Desenvolvimento Gerencial para Empresas de Projeto", passando posteriormente a denominar-se "Soluções para Empresas de Projeto", e teve como objetivo a apresentação do modelo às empresas de projeto participantes, motivando e facilitando sua implementação de forma coletiva.

A escolha para a condução do programa através de grupos de trabalho formados por empresas de projeto visava, além da implementação do modelo de gestão, o desenvolvimento setorial por meio da cooperação e troca de experiências entre as empresas e os pesquisadores.

Para as empresas, o trabalho em grupo possibilitou, além da troca constante de experiências, ampla discussão coletiva de problemas comuns, sistematização de ações para implementação do modelo, além da constante exposição de soluções gerenciais bem sucedidas, as quais poderiam ser utilizadas como referências para análise e solução de problemas individuais das demais empresas dos grupos.

O trabalho de pesquisa através dos grupos ofereceu aos pesquisadores a oportunidade de interação frequente e sistematizada (reuniões coletivas, visitas às empresas) junto ao objeto pesquisado - as empresas de projeto, possibilitando, dessa forma, a coleta mais abrangente de informações e dados que, por sua vez, conduziram à considerações mais precisas.

Outro aspecto positivo sobre a adoção grupos de trabalho ao invés de estudos de caso individualizados, refere-se ao compromisso e postura das empresas em relação à pesquisa.

Já no ato da adesão, as empresas foram alertadas quanto ao atendimento de expectativas mútuas no grupo de trabalho: para as empresas, a possibilidade de aquisição de conhecimento e desenvolvimento gerencial; para os pesquisadores, a obtenção de informações e dados para pesquisas.

Neste contexto, as empresas assumiram o compromisso de cumprir todas as proposições de trabalho do grupo (realização de tarefas, participação em reuniões e eventos), facilitando, dessa forma, a condução das pesquisas e possibilitando maior desempenho do trabalho. 


\section{$1.3 \quad$ Objetivos}

Este trabalho tem por objetivo analisar a aplicação do Modelo de Gestão para Pequenas Empresas de Projeto de Edifícios proposto por Oliveira (2005).

A análise da aplicação do modelo ocorrerá durante a pesquisa-ação sob dois enfoques:

a) reações das empresas quando da aplicação do modelo (comportamento em grupo, estratégias adotadas quanto à sistematização das ações para implementação do modelo e dificuldades no desenvolvimento das tarefas).

b) resultados alcançados pelas empresas em função da implementação do modelo (resultados gerenciais, mudanças de postura, ferramentas desenvolvidas e continuidade quanto ao desenvolvimento gerencial após o término dos programas).

A partir da revisão bibliográfica e das análises realizadas durante a pesquisa-ação, o presente trabalho objetiva, ainda, a proposição de recomendações para facilitar a aplicação dos conceitos de gestão contidos em cada um dos elementos contemplados no modelo de Oliveira (2005).

As recomendações são propostas levando-se em consideração as características gerais das empresas de projeto, do ambiente no qual estão inseridas, das relações estabelecidas no seu cotidiano e das experiências obtidas através da pesquisaação conduzida durante o programa de desenvolvimento gerencial para empresas de projeto. 


\section{$1.4 \quad$ Método de Pesquisa}

O método de pesquisa adotado no desenvolvimento do trabalho foi do tipo qualitativo, realizado através de pesquisa-ação.

Segundo Thiollent ( 2004), pesquisa-ação é um tipo de pesquisa social com base empírica, que é concebida e realizada em estreita associação com uma ação ou com a resolução de um problema coletivo, no qual os pesquisadores e os participantes representativos da situação ou do problema estão envolvidos de modo cooperativo ou participativo.

Este método foi escolhido em função das peculiaridades do programa no qual a pesquisa está inserida:

$\checkmark$ há uma ampla e explícita interação entre pesquisador e as empresas envolvidas no programa de pesquisa e na hipótese que vem sendo testada.

$\checkmark$ o objeto de investigação não é constituído somente pelas empresas, mas pelo contexto onde estão inseridas e pelos problemas de diferente natureza encontrados nesta situação.

$\checkmark$ será realizado um acompanhamento das decisões das ações e de todas as atividades desenvolvidas durante o processo.

O esquema da Figura 1.4 ilustra como a metodologia da pesquisa-ação auxiliou no encaminhamento das ações para o alcance dos objetivos estabelecidos para a dissertação. 


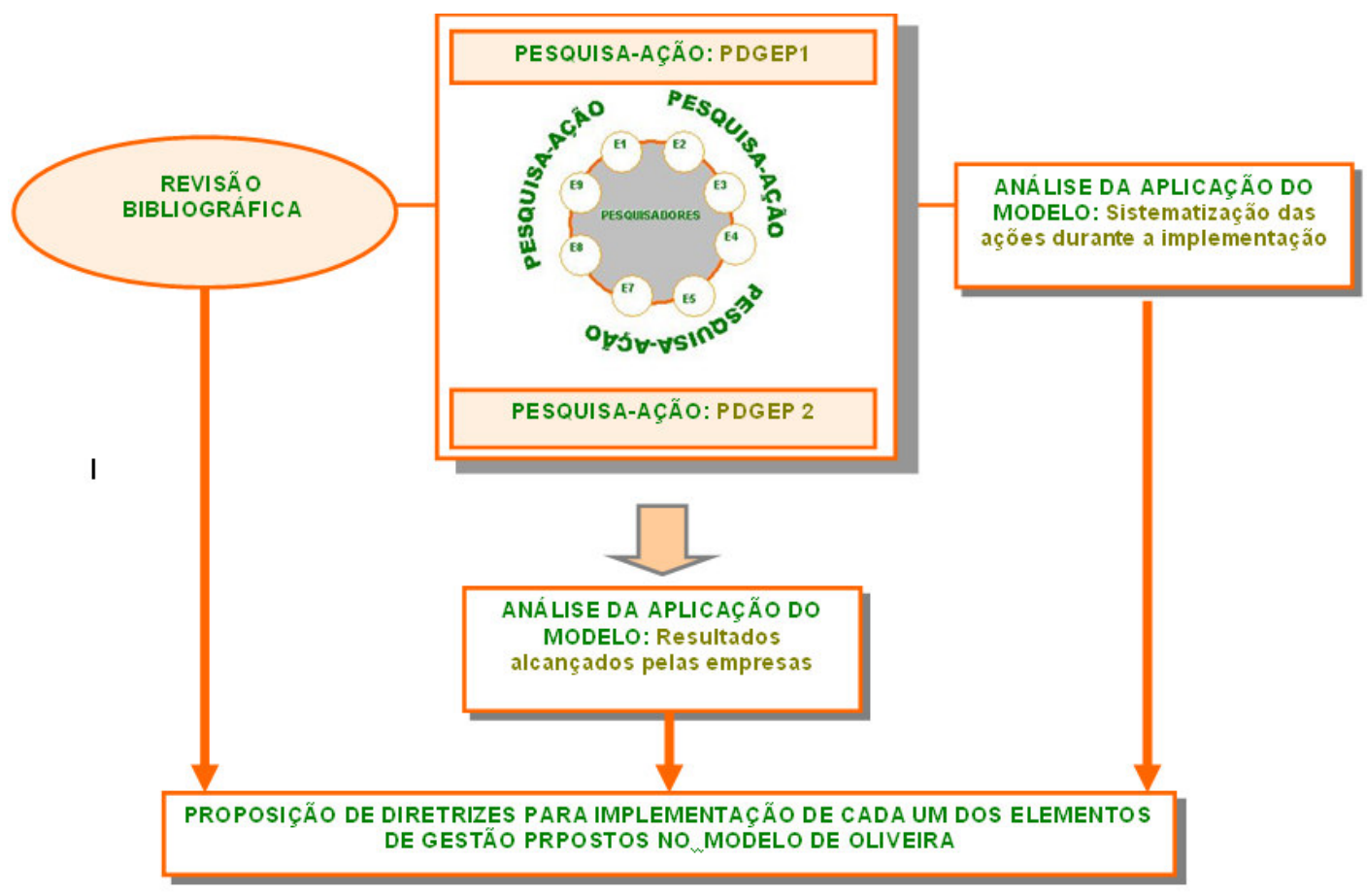

Figura 1.4 - Encaminhamento genérico das etapas de pesquisa

Através desta figura, verifica-se que o trabalho foi encaminhado basicamente através de seis etapas. A pesquisa-ação ocorreu através da formação dos dois grupos de empresas de projeto (Grupo 1 e Grupo 2) que, voluntariamente, aceitaram participar da pesquisa

A pesquisa-ação realizada junto ao Grupo 1 de empresas iniciou-se em maio de 2006. O trabalho foi coordenado pelos Professores Silvio Burrattino Melhado e Otávio José de Oliveira, responsáveis pela coordenação e condução geral do programa. O grupo contou ainda com as participações da Engenheira Flávia Rodrigues de Souza, autora deste trabalho, e da aluna do curso de Graduação em Engenharia Civil da EPUSP, Juliana Setuguti, cujas responsabilidades eram as de auxílio na coordenação e condução do trabalho, além da coleta e organização de dados provenientes da pesquisa-ação.

O Grupo 2 também foi coordenado pelo Professor Silvio Burrattino Melhado, que contou com a colaboração da autora deste trabalho na condução geral do programa, além das pesquisadoras Melissa Hukai, aluna do curso de Graduação em Engenharia Civil da EPUSP e da Arquiteta Mariana Wyse Abaurre, na ocasião, aluna do programa de dupla formação FAU-POLI. 
Tanto no Grupo 1 quanto no Grupo 2, a rotina do programa era sistematizada através dos diagnósticos referentes às práticas usuais de gestão das empresas, reuniões mensais com a participação de todos os participantes do grupo e visitas às empresas.

Todas as empresas participantes do programa deveriam comparecer às reuniões mensais, que tinham por objetivo a apresentação de cada um dos elementos componentes do modelo de gestão separadamente, além da proposição de tarefas a serem desenvolvidas no decorrer do mês por cada uma dessas empresas, baseadas no elemento em discussão na ocasião.

Parte do tempo das reuniões mensais era utilizado para promover interação e troca de experiências entre as empresas e os pesquisadores dos grupos, através de tarefas ou dinâmicas a serem desenvolvidas coletivamente.

As visitas realizadas às empresas participantes eram mensais para o Grupo 1, e bimestrais para o Grupo 2, e objetivavam, em princípio, a coleta de dados para as pesquisas.

Através do trabalho de pesquisa-ação realizado tanto junto ao Grupo 1 quanto junto ao Grupo 2, foi possível realizar a sistematização de ações adotadas durante a implementação do modelo e a análise da sua aplicação. As informações foram complementadas ao final dos programas através do preenchimento de um questionário, cujos objetivos eram, dentre outros, os de obter informações quanto à continuidade ou não do aperfeiçoamento gerencial por parte das empresas, e de compreender quais mudanças ocorreram nas empresas em função de suas participações no PDGEP.

A revisão bibliográfica deu-se ao longo do trabalho de pesquisa-ação (Grupo 1 e Grupo 2, consecutivamente). Para a realização dessa parte do trabalho, foram pesquisadas referências voltadas a cada um dos elementos de gestão componentes do modelo proposto por Oliveira (2005), tanto na área de conhecimento de Administração de Empresas, quanto na área de conhecimento de Engenharia Civil.

A pesquisa referente a cada um dos temas foi conduzida basicamente em três etapas: 
- Revisão Geral do Tema: Nessa etapa, o objetivo era a compreensão geral do tema. Para tanto, foram pesquisados e estudados os autores mais consagrados e referenciados, mesmo que de linhas de pensamento divergentes, já que o conhecimento de diversos pontos de vista sobre mesmo assunto leva à maior compreensão crítica do tema. A maior parte das referências consultadas foram os livros publicados sobre cada um dos assuntos.

- Revisão Específica do Tema: O objetivo dessa etapa era estudar publicações sobre o assunto com foco para pequenas empresas e/ou casos voltados para empresas brasileiras. Foram consultados artigos publicados em periódicos, eventos nacionais e internacionais e os livros disponíveis sobre os assuntos.

- Estruturação: Em função do estudo geral e específico dos assuntos de gestão, as revisões referentes a cada um dos temas (planejamento estratégico, estrutura organizacional, processo de projeto, gestão de recursos humanos, gestão financeira, desempenho, sistema de informação e gestão da qualidade) eram estruturadas de forma a contemplar conceitos aplicáveis às pequenas empresas de projeto de edifícios.

Assim como a revisão bibliográfica, as análises referentes à aplicação do modelo de gestão (sistematização das ações para a sua implementação e resultados alcançados) objetivaram o embasamento para as análises quanto à aplicação do modelo e formulação das diretrizes para a sua implementação.

\section{Estrutura do Trabalho}

Este trabalho foi desenvolvido em cinco capítulos. O Capítulo 1, relativo à introdução, apresenta a contextualização setorial e acadêmica, os objetivos e justificativas para sua realização, e deixa claro o método de pesquisa adotado.

Já o Capítulo 2 contém a análise do modelo de gestão proposto por Oliveira (2005), seguida da revisão bibliográfica pertinente dos elementos de gestão contemplados no modelo citado: estrutura organizacional, gestão do processo de projeto, 
planejamento estratégico, gestão financeira, sistema de informação e comunicação, marketing, recursos humanos, sistema comercial e gestão da qualidade para empresas de projeto.

O Capítulo 3 discorre sobre a pesquisa-ação, contemplando a descrição do contexto da pesquisa, sistematização para a sua condução, relato dos trabalhos coletivos e individuais das empresas e análises quanto a aplicação do modelo no que se refere à reação das empresas na aplicação do modelo e resultados alcançados.

No Capítulo 4 são apresentadas as recomendações para facilitar a aplicação dos conceitos de gestão às empresas de projeto.

Finalmente, o Capítulo 5 pontua as considerações finais do trabalho referentes aos seus objetivos e limitações, a pesquisa-ação junto às empresas de projeto, programa de desenvolvimento gerencial, análises da aplicação do modelo e trabalhos futuros. 


\section{Edifícios}

O objetivo principal do trabalho de Doutoramento de Oliveira (2005) foi o de formular um novo modelo de gestão para pequenas empresas de projeto de edifícios adaptado às suas peculiaridades e com enfoque na gestão da qualidade, proporcionando-Ihes competitividade.

Para tanto, foi necessário que, em função da pesquisa de campo, o autor mapeasse e caracterizasse os principais processos internos das pequenas empresas de projeto de edifícios por meio de estudos de caso e, posteriormente, analisasse holisticamente os sistemas de gestão adotados pelas empresas estudadas e como eles atendem às necessidades dos seus clientes diretos e usuários das edificações por elas projetadas.

O autor divide o modelo em duas etapas: preparação para a implementação e descrição dos elementos de gestão contemplados. Na etapa de preparação, destaca-se principalmente a importância do envolvimento dos colaboradores e da preparação da empresa com relação às mudanças que venham a ocorrer. Quanto à descrição dos elementos, o autor destaca os objetivos e cuidados na implementação.

\subsubsection{Preparação para Implementação do Modelo de Gestão}

Antes da proposição do modelo de gestão, Oliveira (2005) destaca a importância da preparação da pequena empresa de projeto para a implementação propriamente dita. 
O primeiro aspecto destacado pelo autor refere-se ao envolvimento dos colaboradores, pois o sucesso da implementação depende de conhecimentos específicos sobre a realidade dos processos internos da empresa. Sem esses conhecimentos, dificilmente as considerações serão adequadas.

Outro aspecto evidenciado diz respeito ao envolvimento dos colaboradores, ao comprometimento com a implementação do referido modelo, de forma a facilitar a assimilação e adequação dos novos conceitos, práticas e procedimentos. $O$ autor ainda destaca as vantagens do trabalho em grupo, no sentido de favorecer a criatividade e, consequentemente, o desenvolvimento de soluções mais adequadas às especificidades dos diversos processos da empresa.

Por fim, o autor alerta sobre a importância de esclarecer a todos os colaboradores os objetivos da implementação do novo modelo, sua composição, seu desenvolvimento, como ele afetará as atividades de cada um e os resultados que dele se esperam.

Para Oliveira (2005), a decisão referente à estratégia de implementação do modelo deve partir da alta direção com base nas suas necessidades de organização e disponibilidade de recursos financeiros e humanos.

O autor aconselha que, antes do início da implementação do referido modelo, seja realizado um planejamento onde constem prazos, atividades, recursos e responsáveis pelas diversas etapas de implementação. Na seqüência, deve-se estabelecer um plano de treinamento específico para cada um dos elementos que compõem o modelo.

De acordo com Oliveira (2005), é extremamente importante que os dirigentes da empresa de projeto se programem para, além de estudarem minuciosamente a proposta do modelo de gestão a ser implementado, se autocapacitem em noções básicas sobre gestão de empresas através de leitura de livros técnicos da área de administração, participação em seminários, workshops, ou até mesmo por meio de um curso de especialização em administração de empresas.

Ainda com objetivo de preparar a empresa de projeto, Oliveira; Melhado (2003) apresentam algumas diretrizes com o objetivo de viabilizar a implementação e posterior operacionalização do sistema de gestão nas empresas. São elas: 
- Adequação do sistema ao porte da empresa e seus recursos.

- Visualização sistêmica do processo de projeto, considerando suas interações com o ambiente empresarial à sua volta, e os demais subsistemas que compõem a empresa de projeto.

- Adequação da estrutura organizacional da empresa de projeto às características do processo de projeto na construção civil.

- Desenvolvimento e implantação de metodologia para gestão de serviços terceirizados que garantam a qualidade e distribuição de responsabilidades.

- Consideração do nível de empreendedorismo e estilo de liderança existente nas empresas de projeto que, em geral, possuem alto grau de dependência em relação aos seus proprietários.

- Consideração das empresas de projeto tanto como produtoras de produtos, quanto como prestadoras de serviços, reconhecendo que seus profissionais possuem capacidades e características distintas e que, portanto, necessitam de eficazes instrumentos de treinamento e orientação das rotinas de trabalho.

- Clara identificação dos requisitos dos clientes como elemento fundamental para o bom desempenho do processo de projeto.

- Melhoria do sistema de informação da empresa de projeto, utilizando a comunicação entre empreendedor-projetista e projetista-cliente, e a gestão de documentos como indicadores da capacidade da prestação do serviço projeto.

- Implementação da retroalimentação sistemática, de forma a viabilizar o aprimoramento contínuo da atividade de projeto e do sistema de gestão da qualidade como um todo. 


\section{Edifícios}

O modelo de gestão proposto por Oliveira (2005) trata das funções e processos administrativos essenciais às empresas de projeto, sempre procurando privilegiar a simplicidade e flexibilidade dos procedimentos a serem desenvolvidos/controlados.

Está dividido da seguinte forma: Estrutura organizacional; Planejamento estratégico; Planejamento e controle do projeto; Gestão de custos; Gestão comercial; Sistema de informações; Gestão de recursos humanos; Serviços agregados ao projeto e Avaliação de desempenho.

As Tabelas2.1, 2.2, 2.3, 2.4, 2,5, 2.6, 2.7, 2.8 e 2.9 apresentam cada um dos elementos de gestão contemplados no modelo de Oliveira (2005), através do detalhamento dos objetivos de cada um dos elementos, cuidados e seqüência de atividades para a implementação, bem como interface com os demais elementos. 


\begin{tabular}{|c|c|c|}
\hline \multicolumn{3}{|c|}{ Tabela 2.1: Modelo de gestão para pequenas empresas de projeto de edifícios } \\
\hline \multirow{4}{*}{ 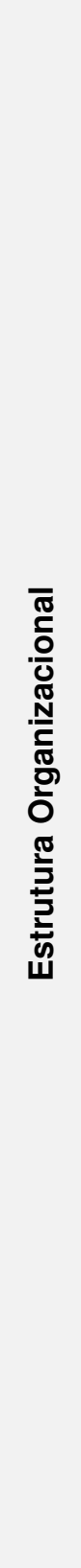 } & 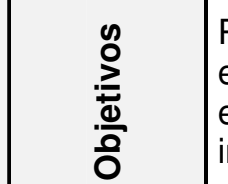 & $\begin{array}{l}\text { Pensar como a nova estrutura permitirá à organização a execução de suas } \\
\text { estratégias e a realização do seu trabalho. Também deve considerar como } \\
\text { ela se harmonizará com os indivíduos que ali trabalham e como será o } \\
\text { impacto sobre as suas atividades. }\end{array}$ \\
\hline & 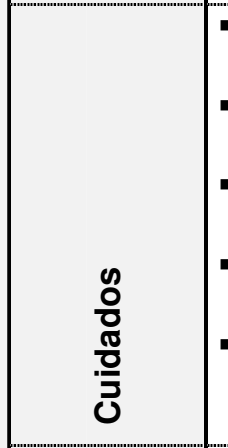 & $\begin{array}{l}\text { - Evitar discrepância dos objetivos e planos principais em relação à } \\
\text { - Evtrutura organizacional. } \\
\text { - exclusivo de um profissional. } \\
\text { - Ao elaborar novos procedimentos (ou remodelar antigos), privilegiar a } \\
\text { clareza como forma de evitar atritos entre colaboradores e sua chefia. } \\
\text { - Evitar, dentro do possível, a múltipla subordinação, ou seja, um } \\
\text { funcionário subordinado a mais de um superior hierárquico. } \\
\text { - Evitar amplitude exagerada de supervisão de tarefas, ou seja, um } \\
\text { mesmo profissional ser responsável por um número de funcionários ou } \\
\text { atividades acima de sua capacidade. }\end{array}$ \\
\hline & 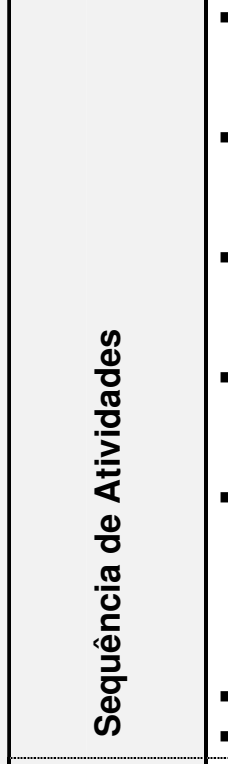 & $\begin{array}{l}\text { - Estabelecer uma estratégia clara: a estrutura de uma organização } \\
\text { deve viabilizar as suas estratégias; para tanto, deve ser coerente com a } \\
\text { forma de trabalho praticada pela empresa. } \\
\text { - Analisar o sistema atual da empresa: devem ser identificadas as } \\
\text { entradas e saídas dos processos da empresa e as possíveis conexões } \\
\text { interrompidas entre as áreas. } \\
\text { - Documentar os processos atuais: mapear e descrever o fluxo atual } \\
\text { dos processos que tenham maior impacto sobre a estratégia da } \\
\text { empresa. } \\
\text { Desenvolver medidas para os processos atuais: criar indicadores } \\
\text { para os principais processos da empresa, de forma a verificar o seu } \\
\text { desempenho. } \\
\text { Projetar o Organograma: partindo da situação desejada em relação } \\
\text { aos processos internos da empresa, determinar os agrupamentos } \\
\text { departamentais e os relacionamentos hierárquicos mais lógicos para a } \\
\text { empresa, de forma a estabelecer fronteiras organizacionais claras e } \\
\text { efetivamente interligadas. } \\
\text { Desenvolver as atribuições para cada setor/departamento. } \\
\text { Desenvolver as atribuicões para cada cargo. }\end{array}$ \\
\hline & 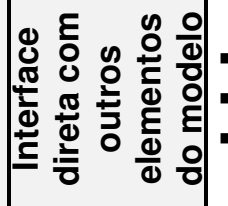 & $\begin{array}{l}\text { - Planejamento Estratégico } \\
\text { - Gestão de Recursos Humanos } \\
\text { - Avaliação de Desempenho }\end{array}$ \\
\hline
\end{tabular}


Tabela 2.2: Modelo de gestão para pequenas empresas de projeto de edifícios

\begin{tabular}{|c|c|c|}
\hline \multirow{4}{*}{ 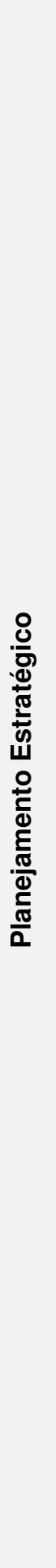 } & $\frac{\stackrel{0}{0}}{\stackrel{0}{0}}$ & $\begin{array}{l}\text { Por meio do planejamento estratégico será possível conhecer e melhor } \\
\text { utilizar os pontos fortes da empresa; conhecer, eliminar ou adequar os seus } \\
\text { pontos fracos; conhecer e aproveitar as oportunidades externas, assim } \\
\text { como evitar as ameaças; criar uma agenda para objetivos e metas da } \\
\text { empresa. }\end{array}$ \\
\hline & 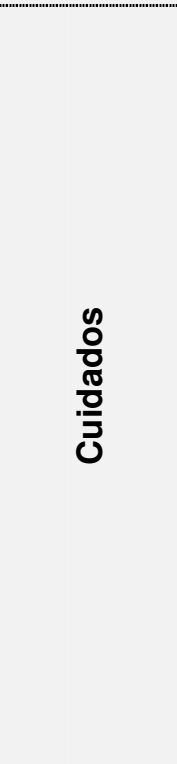 & $\begin{array}{l}\text { - Por se tratar de uma atividade complexa face ao grande número de } \\
\text { condicionantes organizacionais, a eficácia do planejamento estratégico } \\
\text { depende da solidez das informações disponíveis, da definição precisa } \\
\text { dos objetivos, da previsão de alternativas e da predominância da "ação" } \\
\text { na empresa. } \\
\text { - A definição das estratégias deve ser fixada no cliente e nas suas reais } \\
\text { necessidades. } \\
\text { - É fundamental para a empresa a capacidade de estabelecer vantagens } \\
\text { competitivas e de detectar, o mais cedo possível, potenciais } \\
\text { oportunidades de negócios. } \\
\text { O planejamento estratégico deve ser estruturado de forma a permitir a } \\
\text { integração da estrutura organizacional, direcionamento de esforços e } \\
\text { consolidação do entendimento por todos os colaboradores da missão, } \\
\text { propósitos, estratégias, objetivos, metas e políticas da empresa. } \\
\text { Apesar do planejamento estratégico ser de responsabilidade da alta } \\
\text { direção, ele deve estar assessorado por outros colaboradores. } \\
\text { Embora a maioria das empresas de projeto provavelmente tenha um } \\
\text { plano estratégico "implícito", elaborado por meio de tentativa e erro, é } \\
\text { importante dar um caráter formal a esse plano. }\end{array}$ \\
\hline & 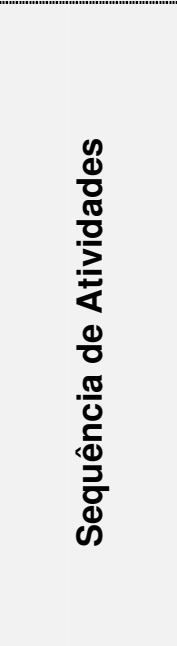 & $\begin{array}{l}\text { - Análise do ambiente externo: tendo em vista que a estratégia procura } \\
\text { adaptar a empresa com sucesso ao seu ambiente externo, a análise } \\
\text { das ameaças e das oportunidades de mercado torna-se elemento } \\
\text { fundamental para o sucesso desse processo. } \\
\text { Análise do ambiente interno: devem ser verificados para todas as } \\
\text { atividades da empresa de projeto, tais como: conhecimento de } \\
\text { mercado, assistência ao cliente, qualidade dos projetos e dos serviços } \\
\text { agregados, marketing, recursos humanos, desenvolvimento do projeto, } \\
\text { controle de documentação, finanças, etc. } \\
\text { Análise da situação estratégica da empresa: para analisar } \\
\text { (diagnosticar) a situação estratégica atual da empresa, é necessário } \\
\text { que se estude a sua missão, seus produtos e serviços e suas vantagens } \\
\text { competitivas. } \\
\text { Definição da missão, objetivos e estratégias: é importante que as } \\
\text { principais características de projeto, bem como seu público alvo, } \\
\text { estejam devidamente identificados e apresentados. }\end{array}$ \\
\hline & 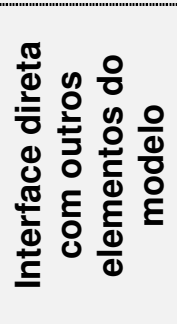 & $\begin{array}{ll}\text { - } & \text { Estrutura Organizacional } \\
\text { - } & \text { Gestão de Recursos Humanos } \\
\text { - } & \text { Marketing e Gestão Comercial } \\
\text { - } & \text { Sistema de Informação } \\
\text { - } & \text { Processo de Projeto } \\
\text { - } & \text { Serviços Agregados } \\
& \text { Avaliação de Desempenho }\end{array}$ \\
\hline
\end{tabular}




\begin{tabular}{|c|c|c|}
\hline \multicolumn{3}{|c|}{ abela 2.3: Modelo de gestão para pequenas empresas de projeto de edifícios } \\
\hline \multirow{4}{*}{ 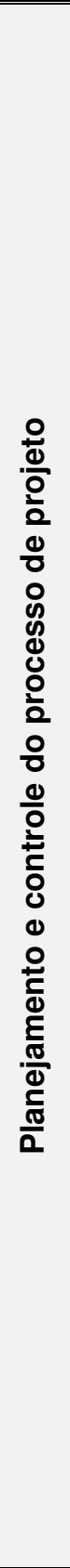 } & 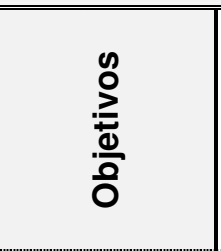 & $\begin{array}{l}\text { A elaboração de instrumentos para planejamento e controle do processo } \\
\text { de projeto traz consideráveis benefícios ao processo de avaliação final do } \\
\text { projeto, tanto em relação aos aspectos técnicos quanto com relação aos } \\
\text { aspectos de gestão, possibilitando que sejam estabelecidas diretrizes para } \\
\text { aprimoramento dos novos projetos, por meio da comparação entre as } \\
\text { atividades previstas e as realmente realizadas. }\end{array}$ \\
\hline & $\begin{array}{l}\mathscr{0} \\
\frac{0}{0} \\
\frac{\pi}{0} \\
: \frac{0}{3} \\
0\end{array}$ & $\begin{array}{l}\text { Para planejamento e controle do andamento das atividades de } \\
\text { desenvolvimento do projeto é necessário entender e identificar as } \\
\text { interações existentes entre elas, sempre tomando como base o } \\
\text { escopo do projeto definido entre a empresa e o cliente. } \\
\text { - É aconselhável que a equipe responsável pelo desenvolvimento dos } \\
\text { trabalhos de projeto participe da confecção dos instrumentos de } \\
\text { planejamento e controle do processo de projeto. } \\
\text { Ressalte-se que as atividades que compõem o desenvolvimento do } \\
\text { projeto variam para tipos diferentes de disciplinas de projeto e, } \\
\text { portanto, cada empresa, em função da sua especialidade, terá uma } \\
\text { sequência distinta de atividades a serem planejadas e controladas. }\end{array}$ \\
\hline & 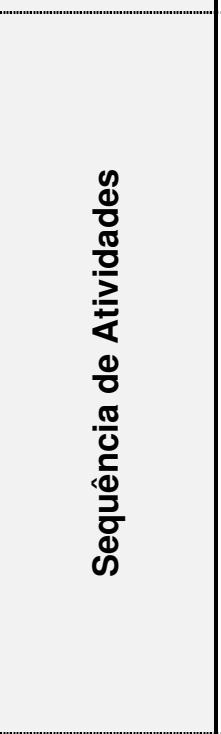 & $\begin{array}{l}\text { Confecção da lista sequencial das atividades que comporão o } \\
\text { processo de projeto: nesta fase, é muito importante a identificação } \\
\text { tanto das atividades independentes quanto das atividades } \\
\text { interdependentes que compõem o processo de projeto. Nesse } \\
\text { momento, ainda não é necessário possuir alto grau de exatidão em } \\
\text { relação a prazos e custos; trata-se apenas de uma tentativa de } \\
\text { visualização do fluxo geral de atividades e suas relações de } \\
\text { dependência para posterior planejamento do processo de projeto. } \\
\text { Detalhamento individual de cada atividade: deve-se avançar no } \\
\text { detalhamento de cada uma das tarefas, pensando sistematicamente } \\
\text { de forma a otimizar principalmente a utilização dos recursos humanos } \\
\text { em função da complexidade e duração das tarefas. } \\
\text { Planejamento de todo o processo: de posse dos parâmetros } \\
\text { (escopo de projeto, fluxo geral de atividades, detalhamento dos } \\
\text { subprocessos, estimativa de mão-de-obra, tempo/custo para cada } \\
\text { uma das atividades), é possível operacionalizar o planejamento do } \\
\text { processo de projeto, bem como estabelecer as ferramentas de } \\
\text { controle. }\end{array}$ \\
\hline & 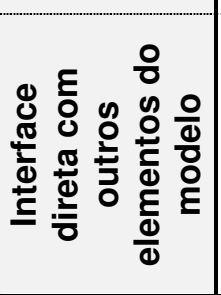 & $\begin{array}{ll}\text { - } & \text { Planejamento Estratégico } \\
\text { - } & \text { Gestão de Recursos Humanceira } \\
\text { - } & \text { Sisteting e Gestão Comercial } \\
\text { - } & \text { Serviços Agregarmação } \\
& \text { Avaãa de Desempenho }\end{array}$ \\
\hline
\end{tabular}


Tabela 2.4: Modelo de gestão para pequenas empresas de projeto de edifícios

\begin{tabular}{|c|c|c|}
\hline \multirow{4}{*}{ 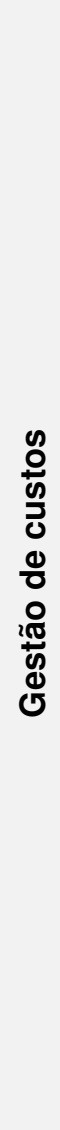 } & 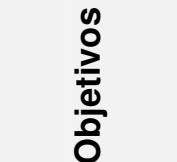 & $\begin{array}{l}\text { Desenvolver instrumentos simplificados para organização e controle das } \\
\text { receitas, dos custos fixos e dos custos diretos da pequena empresa de } \\
\text { projetos de edifícios. }\end{array}$ \\
\hline & 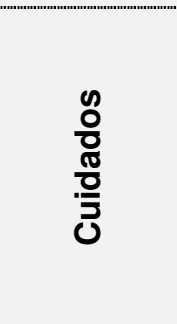 & $\begin{array}{l}\text { - O sistema de gestão financeira deve subsidiar a apuração parcial dos } \\
\text { resultados financeiros dos projetos em andamento e a análise periódica } \\
\text { dos resultados de rentabilidade da empresa. } \\
\text { O custo direto de maior importância e peso no custo total para a } \\
\text { atividade de projeto é a mão-de-obra especializada para sua execução. } \\
\text { Por este motivo, tal custo deve ser criteriosamente previsto no momento } \\
\text { da elaboração do preço do projeto, e acompanhado com rigidez quando } \\
\text { da sua execução. }\end{array}$ \\
\hline & 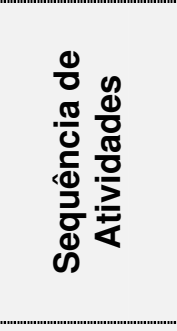 & $\begin{array}{l}\text { - Organizar os custos: fixos ou indiretos e variáveis ou diretos. } \\
\text { - Elaborar uma ferramenta com objetivo de medir as horas } \\
\text { despendidas em cada um dos projetos, de forma a subsidiar o } \\
\text { controle financeiro de cada um dos projetos. } \\
\text { - Para auxiliar o planejamento estratégico o marketing, podem ser } \\
\text { elaborados gráficos simplificados que demonstrem a distribuição } \\
\text { das receitas da empresa por tipo de projeto ou obra, por clientes, } \\
\text { por região, etc. }\end{array}$ \\
\hline & 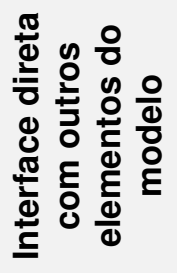 & $\begin{array}{l}\text { - } \quad \text { Planejamento Estratégico } \\
\text { - } \quad \text { Gestão de Recursos Humanos } \\
\text { - } \quad \text { Sistema de Gestão Comercial } \\
\text { - } \quad \text { Avaliação de Desemperão }\end{array}$ \\
\hline
\end{tabular}


Tabela 2.5: Modelo de gestão para pequenas empresas de projeto de edifícios

\begin{tabular}{|c|c|c|}
\hline \multirow{4}{*}{ 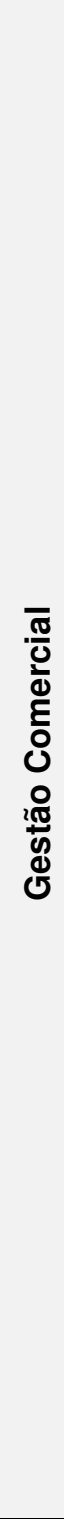 } & $\frac{\stackrel{0}{0}}{\stackrel{0}{0}}$ & $\begin{array}{l}\text { Definir estratégias e ferramentas de marketing com o objetivo de fazer com } \\
\text { que o cliente perceba que o serviço "projeto" é parte indissociável do } \\
\text { produto edifício e, dessa forma, crie a sensação de necessidade desse } \\
\text { serviço, além de estabelecer um método para precificação dos projetos e } \\
\text { elaboração das propostas técnico- comerciais. }\end{array}$ \\
\hline & 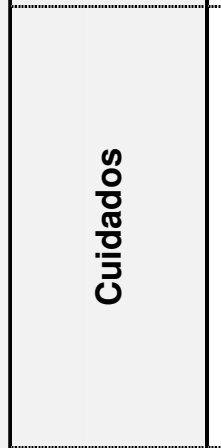 & $\begin{array}{l}\text { Desenvolver estratégias de marketing alinhadas ao nível de percepção } \\
\text { que o cliente possui sobre o serviço projeto. } \\
\text { - Escolher a forma correta de mídia para a perfeita comunicação com } \\
\text { atuais e potenciais clientes. } \\
\text { - Adaptar-se e desenvolver habilidades para lidar de maneira proativa } \\
\text { com o setor da construção civil. } \\
\text { Elaborar as propostas técnico-comerciais como referências que } \\
\text { possibilitem o controle das atividades do desenvolvimento do projeto } \\
\text { propriamente dito. } \\
\text { Entender as reais necessidades dos clientes para a perfeita proposição } \\
\text { das diversas possibilidades do serviço de projeto. }\end{array}$ \\
\hline & 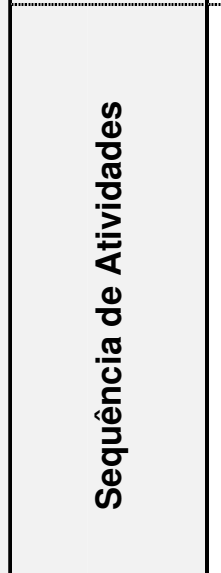 & $\begin{array}{l}\text { - Alinhar as estratégias de marketing da empresa ao planejamento } \\
\text { estratégico. } \\
\text { Formular ferramentas de marketing e gestão comercial que } \\
\text { possibilitem a retroalimentação do planejamento estratégico. } \\
\text { Definir um método para apuração da quantidade de recursos } \\
\text { despendidos na elaboração de projeto por tipologia. } \\
\text { Elaborar um método para desenvolvimento de propostas técnico- } \\
\text { comerciais de modo a: formalizar a intenção do estabelecimento de } \\
\text { uma relação comercial; informar o que a empresa está se } \\
\text { propondo a executar, a que preço, em que prazo e de que forma; } \\
\text { esclarecer as principais obrigações de cada uma das partes; } \\
\text { estabelecer as partes técnicas e gerenciais introdutórias para } \\
\text { nortear os serviços a serem executados e servir como instrumento } \\
\text { de marketing. }\end{array}$ \\
\hline & 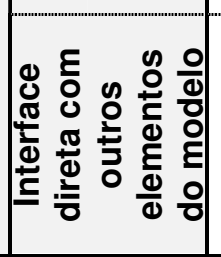 & $\begin{array}{l}\text { - } \quad \text { Planejamento Estratégico } \\
\text { - } \quad \text { Gestão de Recursos Humanos } \\
\text { - } \quad \text { Sistema de Informação } \\
\text { - } \quad \text { Processo de Projeto } \\
\text { - } \quad \text { Avaliação de Desempenho }\end{array}$ \\
\hline
\end{tabular}




\begin{tabular}{|c|c|c|}
\hline \multicolumn{3}{|c|}{ Tabela 2.6: Modelo de gestão para pequenas empresas de projeto de edifícios } \\
\hline \multirow{4}{*}{ 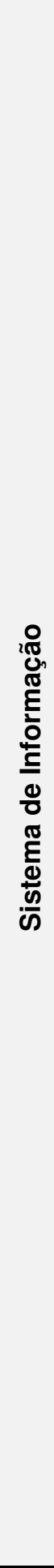 } & 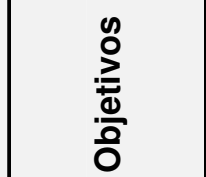 & $\begin{array}{l}\text { Criar mecanismos simples e consistentes para emissão, recebimento e } \\
\text { armazenagem das informações necessárias para o processo de projeto e } \\
\text { para a gestão da empresa de projeto, de forma a facilitar a disponibilidade e } \\
\text { a quantidade da informação no momento certo. }\end{array}$ \\
\hline & 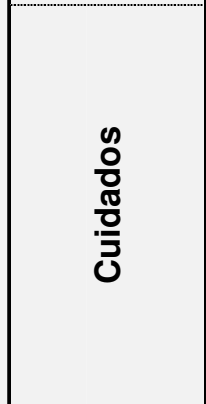 & $\begin{array}{l}\text { Compreender que existem nas empresas de projeto três formas } \\
\text { principais de informações: (a) informações físicas (plantas, folhetos, } \\
\text { croquis, rascunhos e documentos impressos em geral); (b) } \\
\text { informações digitais (arquivos digitais de plantas, documentos } \\
\text { armazenados em depositórios de arquivos, mensagens eletrônicas, } \\
\text { etc.); (c) informações verbais (entrevistas, reuniões, conversas via } \\
\text { telefone, conversas informais). } \\
\text { Delinear o sistema de informações de forma a proporcionar à } \\
\text { empresa maior padronização, segurança, economia de tempo e } \\
\text { produtividade. }\end{array}$ \\
\hline & 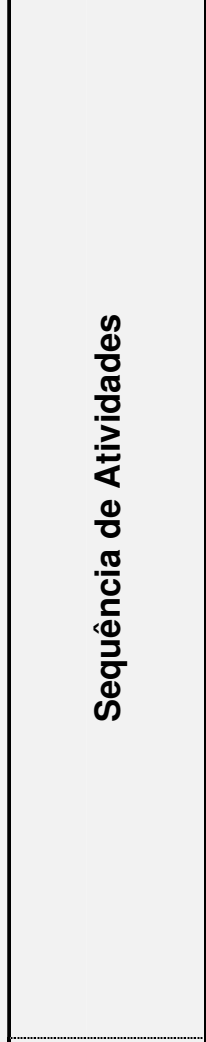 & $\begin{array}{l}\text { Ferramentas sugeridas para a organização do sistema de } \\
\text { informação na relação projetista/contratante: check-list para a } \\
\text { elaboração do briefing de projeto; procedimento para controle das } \\
\text { informações verbais, físicas ou digitais, seu recebimento e envio } \\
\text { durante o processo de projeto; procedimento para garantir a } \\
\text { rastreabilidade das informações; desempenho de procedimento e } \\
\text { ferramenta para acompanhar o desempenho do processo de projeto. } \\
\text { Ferramentas sugeridas para a organização do sistema de } \\
\text { informação na relação projetista/projetista: criação de um banco de } \\
\text { dados contendo informações institucionais e técnicas sobre todas as } \\
\text { empresas de projetos parceiras; definição de ferramentas, tais como: } \\
\text { atas de reunião, programação do trabalho de projeto, programa e } \\
\text { formatação das reuniões, formatação das informaçães de projetos. } \\
\text { Ferramentas sugeridas para a organização do sistema de } \\
\text { informação na relação projetista/obra: formulário para registro de } \\
\text { dados institucionais sobre as construtoras que trabalham com os } \\
\text { projetos e dados institucionais; criação de impresso específico para } \\
\text { comunicação com a obra; criação de metodologia para avaliação de } \\
\text { construtibilidade das soluções propostas em projeto. } \\
\text { Ferramentas sugeridas para a organização do sistema de } \\
\text { informação na relação projetista/usuários: elaboração de um check- } \\
\text { list contendo perguntas-chave para serem aplicadas aos potenciais } \\
\text { usuários do empreendimento, visando a elaboração do programa; } \\
\text { realização da Avaliação Pós-Ocupação (APO), a fim de verificar o } \\
\text { desempenho do projeto junto aos usuários e aos administradores } \\
\text { prediais. }\end{array}$ \\
\hline & 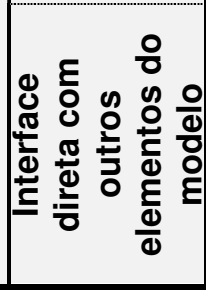 & $\begin{array}{ll}\text { - } & \text { Planejamento Estratégico } \\
\text { - } & \text { Gestão de Recursos Humanos } \\
\text { - } & \text { Marketing e Gestão Comercial } \\
\text { - } & \text { Processo de Projeto } \\
\text { - } & \text { Avaliação de Desempenho } \\
\end{array}$ \\
\hline
\end{tabular}




\begin{tabular}{|c|c|c|}
\hline \multicolumn{3}{|c|}{ Tabela 2.7: Modelo de gestão para pequenas empresas de projeto de edifícios } \\
\hline \multirow{4}{*}{ 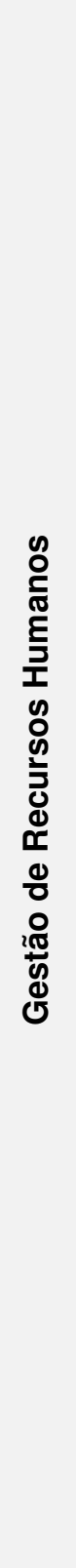 } & 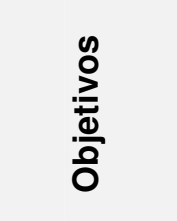 & $\begin{array}{l}\text { Propor procedimentos simples e básicos para a contratação de } \\
\text { colaboradores, educação continuada e treinamento, bem como para a } \\
\text { organização das terceirizações, com enfoque para o aperfeiçoamento } \\
\text { tecnológico dos profissionais, melhoria do clima organizacional e garantia de } \\
\text { melhor qualidade dos projetos realizados pela empresa. }\end{array}$ \\
\hline & 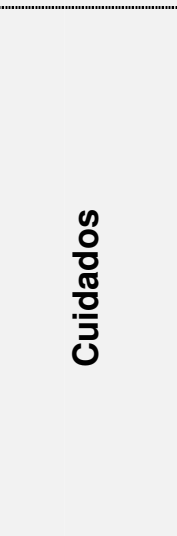 & $\begin{array}{l}\text { Motivação: o responsável pela empresa deve se preocupar em gerar } \\
\text { mecanismos que despertem o interesse dos seus subordinados pelo } \\
\text { trabalho que realizam. } \\
\text { - Organização e clima organizacional: o profissional titular deve estar } \\
\text { ciente de que estilo de comando, salários, políticas de administração de } \\
\text { pessoal e condições físicas de execução das atividades, se bem } \\
\text { administrados, criam um clima psicológico saudável na empresa. } \\
\text { - Formação: priorizar o treinamento e formação continuada dos } \\
\text { profissionais de projeto, tendo em vista que a grande velocidade no } \\
\text { desenvolvimento das inovações tecnológicas é uma realidade com a } \\
\text { qual as empresas de projeto têm que conviver. } \\
\text { Terceirização: tratar como realidade a terceirização de projetos e, } \\
\text { portanto, estabelecer procedimentos para sua contratação e controle. }\end{array}$ \\
\hline & 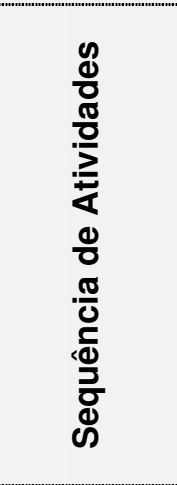 & $\begin{array}{l}\text { - Criar mecanismos para o enriquecimento do trabalho no dia-a-dia, } \\
\text { propondo aos profissionais de projeto a diversidade na execução de } \\
\text { tarefas, (incorporação dos fatores de desafio, decisão e possibilidade de } \\
\text { progresso), possibilidade de autogestão das atividades, criação de } \\
\text { programas de incentivo e instituição de um plano de cargos e salários } \\
\text { coerente com a realidade da empresa. } \\
\text { Elaborar um plano de treinamento, com base na disponibilidade } \\
\text { financeira da empresa, que contemple todo o quadro de funcionários, } \\
\text { priorizando os que atuam diretamente nos processos mais críticos. } \\
\text { Estabelecimento de procedimento para a terceirização de projetos, } \\
\text { com instruções para formulação de contrato, definição de } \\
\text { responsabilidades e possíveis treinamentos. }\end{array}$ \\
\hline & 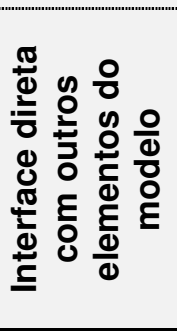 & $\begin{array}{ll} & \text { Planejamento Estratégico } \\
\text { - } & \text { Gestão Financeira } \\
\text { - } & \text { Procesting e Gestão Comercial } \\
\text { - } & \text { Serviços Agregadoto } \\
\text { - } & \text { Avaliação de Desempenho } \\
\text { - } & \text { Estrutura Organizaçonal } \\
\end{array}$ \\
\hline
\end{tabular}


Tabela 2.8: Modelo de gestão para pequenas empresas de projeto de edifícios

\begin{tabular}{|c|c|c|}
\hline \multirow{4}{*}{ 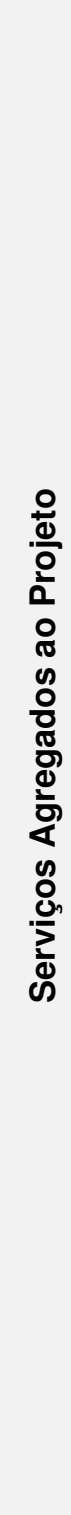 } & $\frac{\stackrel{0}{0}}{\stackrel{2}{\frac{1}{2}}}$ & $\begin{array}{l}\text { Estabelecimento de práticas com objetivo de criar uma linha direta de } \\
\text { comunicação com o cliente e usuários do projeto (contratante, obra e } \\
\text { usuário da edificação) e, dessa forma, aperfeiçoar continuamente o } \\
\text { processo de projeto. }\end{array}$ \\
\hline & $\begin{array}{l}\stackrel{0}{\frac{0}{0}} \\
\frac{\pi}{\pi} \\
\frac{0}{3}\end{array}$ & $\begin{array}{l}\text { - Estabelecer procedimentos que contribuam significativamente com } \\
\text { os relacionamentos comerciais existentes, para a melhoria dos } \\
\text { próximos projetos e, consequentemente, para a geração de futuros } \\
\text { contratos. }\end{array}$ \\
\hline & 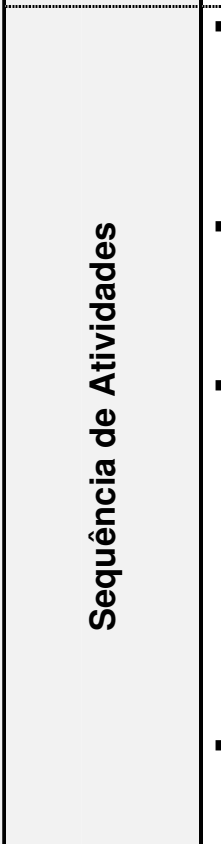 & $\begin{array}{l}\text { Entrega e apresentação do projeto: a entrega e apresentação do } \\
\text { projeto, além de ser um instrumento importante na sua validação, é de } \\
\text { extrema importância para a equipe de execução quanto à compreensão } \\
\text { das soluções projetuais propostas, contribuindo para a diminuição de } \\
\text { solicitações de assistência e eventuais alterações. } \\
\text { Validação do projeto: estabelecer um procedimento de validação do } \\
\text { projeto por parte do contratante. Para o caso de edificações mais } \\
\text { complexas, sugere-se que os projetos sejam entregues em etapas, } \\
\text { validadas individualmente pelo cliente. } \\
\text { Assistência à obra: prever em contrato visitas técnicas à obra, } \\
\text { programadas de acordo com o tempo de duração e complexidade do } \\
\text { projeto, pois esse procedimento gera benefícios para ambas as partes } \\
\text { no relacionamento comercial: o contratante garante melhor } \\
\text { interpretação dos detalhes de projeto e, consequentemente, reduz os } \\
\text { custos com desperdícios na execução da obra; já o projetista pode } \\
\text { identificar o grau de construtibilidade e as principais deficiências do seu } \\
\text { projeto, utilizando-as como elementos para retroalimentação de futuros } \\
\text { projetos. } \\
\text { Assistência técnica: disponibilizar canais de comunicação direta com o } \\
\text { contratante, de forma a resolver, no menor tempo possível, as dúvidas e } \\
\text { solicitações de alterações de projeto. }\end{array}$ \\
\hline & 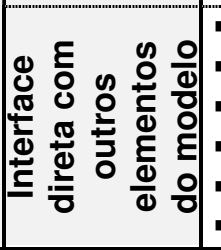 & $\begin{array}{l}\text { - } \quad \text { Planejamento Estratégico } \\
\text { - } \quad \text { Procketing e Gestão Comercial } \\
\text { - } \quad \text { Gestão de Recursos Humanos } \\
\text { - } \quad \text { Avaliação de Desempenho } \\
\text { - Sistema de Informações }\end{array}$ \\
\hline
\end{tabular}




\begin{tabular}{|c|c|c|}
\hline \multicolumn{3}{|c|}{ Tabela 2.9: Modelo de gestão para pequenas empresas de projeto de edifícios } \\
\hline \multirow{4}{*}{ 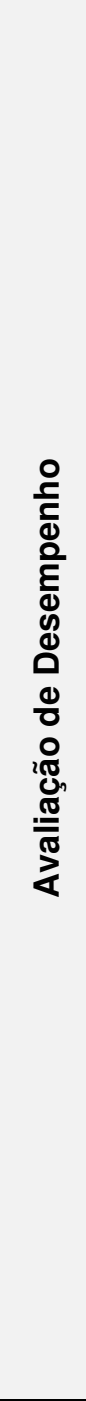 } & 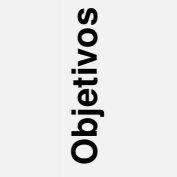 & $\begin{array}{l}\text { Proposição de sistemática para avaliação do desempenho dos projetos } \\
\text { desenvolvidos pela empresa e avaliação do desempenho do sistema de } \\
\text { gestão das empresas de projeto. }\end{array}$ \\
\hline & $\begin{array}{l}\text { o } \\
\frac{0}{0} \\
\frac{\pi}{0} \\
\frac{0}{3}\end{array}$ & $\begin{array}{l}\text { - A avaliação do desempenho dos projetos deve ser pautada no grau } \\
\text { de satisfação do usuário, do construtor e do contratante. } \\
\text { - A investigação deve ser pautada em instrumentos objetivos e diretos, } \\
\text { que verifiquem, além de aspectos técnicos específicos sobre projeto, } \\
\text { itens como prazo, preço, clareza, grau de compatibilização com outras } \\
\text { especialidades, assistência técnica, etc. } \\
\text { - Quanto aos indicadores de desempenho do sistema de gestão da } \\
\text { empresa, deve-se tomar o cuidado para que não se tornem mais } \\
\text { importantes que a execução dos processos em si, subvertendo a } \\
\text { prioridade de funções e processos estabelecidos neste modelo. } \\
\text { - Sistematizar a análise crítica das informações obtidas em função dos } \\
\text { indicadores, bem como as decisões e ações posteriores. }\end{array}$ \\
\hline & 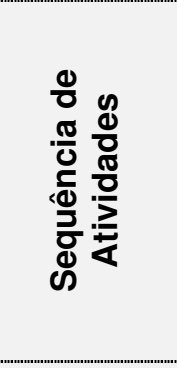 & $\begin{array}{l}\text { - Aplicação de questionário aos contratantes e usuários do projeto. } \\
\text { - Tornar a prática de visita à obra um instrumento de coleta de } \\
\text { informações. } \\
\text { Em relação aos usuários das edificações, lançar mão das técnicas } \\
\text { já conhecidas de Avaliação Pós-Ocupação (APO). } \\
\text { Desenvolver indicadores de desempenho relacionados à } \\
\text { produtividade da mão-de-obra, à quantificação de retrabalhos em } \\
\text { projeto, ao custo de trabalho para cada projeto, à verificação do } \\
\text { clima organizacional, e ao alcance dos objetivos estratégicos. }\end{array}$ \\
\hline & 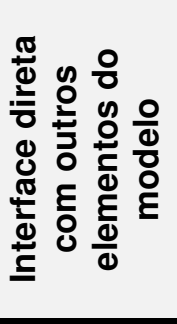 & $\begin{array}{ll}\text { - } & \text { Planejamento Estratégico } \\
\text { - } & \text { Gestão Financeira } \\
\text { - } & \text { Procesesso de Projtajo Comero } \\
\text { - } & \text { Serviços Agregados } \\
\text { - } & \text { Gestão de Recursos Humanos } \\
\text { - } & \text { Estrutura Organizaçónanal } \\
\end{array}$ \\
\hline
\end{tabular}

Embora o autor proponha um modelo de gestão com elementos pré-definidos, verifica-se o cuidado da não apresentação de soluções prontas ou procedimentos padrões. Nesse sentido, são propostas diretrizes para o desenvolvimento de cada um dos elementos de gestão, cabendo à empresa de projeto compreendê-las e aplicá-las à sua realidade através do desenvolvimento de sistemáticas de trabalho e 
de ferramentas que subsidiem o acompanhamento e o controle das atividades de gestão da empresa.

Percebe-se preocupação por parte do autor em motivar o amadurecimento da empresa de projeto do ponto de vista da gestão, pois a etapa que antecede a aplicação dos procedimentos e ferramentas de gestão é de fundamental importância para o crescimento da empresa, para a valorização da gestão na sua rotina de trabalho e, principalmente, para o entendimento de que a gestão é um processo de contínua análise crítica, reavaliação e proposição de ferramentas com um nível de aperfeiçoamento crescente.

Em função do perfil dos profissionais titulares das empresa de projeto e dos próprios projetistas colaboradores atuantes neste segmento, o autor tomou o cuidado de propor o modelo de gestão de forma a não causar a impressão de que a gestão sobrepõe a atividade projetual. O modelo é colocado como elemento que subsidia e facilita a atividade principal dessas empresas, qual seja, a atividade técnica de projetar.

Outro aspecto verificado na proposta do autor é a interdependência entre os diversos elementos de gestão. A discussão de cada um desses elementos não elimina os demais, pois o que torna o modelo aplicável e eficaz como sistema de gestão é justamente o cuidado com relação às interfaces. Nesse sentido, Deming (1990) explica que, em praticamente todos os sistemas existe interdependência entre os seus elementos e, portanto, o adequado gerenciamento de um sistema exige o conhecimento das inter-relações entre os seus diversos componentes.

Nos próximos itens desse capítulo serão discutidos os conceitos ${ }^{1}$ referentes aos elementos de gestão contemplados no modelo de Oliveira (2005): estrutura organizacional, processo de projeto, planejamento estratégico, gestão financeira, sistema de informação, gestão comercial e marketing, gestão de pessoas, gestão por desempenho e gestão da qualidade. 
Oliveira (2006) define estrutura organizacional como um instrumento administrativo resultante da identificação, análise, ordenação e agrupamento das atividades e dos recursos das empresas, incluindo os estabelecimentos dos níveis de alçada e dos processos decisórios, visando o alcance dos objetivos definidos pela empresa.

Para Mintzberg (2003), a estrutura de uma organização consiste na soma total das maneiras pelas quais o trabalho é dividido em tarefas distintas, e como é realizada a coordenação entre as mesmas.

Segundo Maximiano (2004), o trabalho final que resulta na estrutura organizacional consiste em entender a empresa como um sistema de recursos que procura alcançar objetivos, e passa por um processo que este mesmo autor denomina como "processo de organizar", que consiste em definir os objetivos a serem atingidos pela empresa e identificar quais recursos pretende utilizar para atingir tal finalidade, dividir o trabalho, definir responsabilidades e autoridade. Para o autor, é em função do "processo organizar" que são criadas as estruturas organizacionais nas empresas.

Em função das definições de Oliveira (2006), Maximiano (2004) e Mintzberg (2003), conclui-se que a estrutura organizacional é um instrumento de gestão que possui como objetivo maior organizar o trabalho e fazer cumprir os objetivos estratégicos da empresa.

Verifica-se, através da revisão bibliográfica, que os objetivos em torno do instrumento estrutura organizacional evoluíram ao longo do tempo. Partindo de uma visão contemporânea sobre gestão, na qual é estabelecida uma relação bastante íntima entre estrutura e tecnologia, e analisando esses dois aspectos em condições de igualdade do ponto de vista estratégico, Sauer e Willcocks (2003) colocam que os sistemas de informações potencializam a capacidade de coordenação e gestão requerida da estrutura organizacional, provendo recursos para comunicação, estrutura colaborativa e flexibilidade.

\footnotetext{
${ }^{1}$ A revisão bibliográfica referente ao item serviços agregados, parte do modelo de Oliveira (2005), não será realizada nessa dissertação, pois entende-se como parte do processo de projeto e gestão de desempenho, portanto é contemplada contempla em ambos os itens.
} 
Para Mintzberg (2003), toda atividade humana organizada dá origem a duas exigências fundamentais e opostas, que são a divisão do trabalho em várias tarefas, representado através da forma, e a coordenação destas tarefas para a realização da atividade fim, conforme mostra a Figura 2.1.

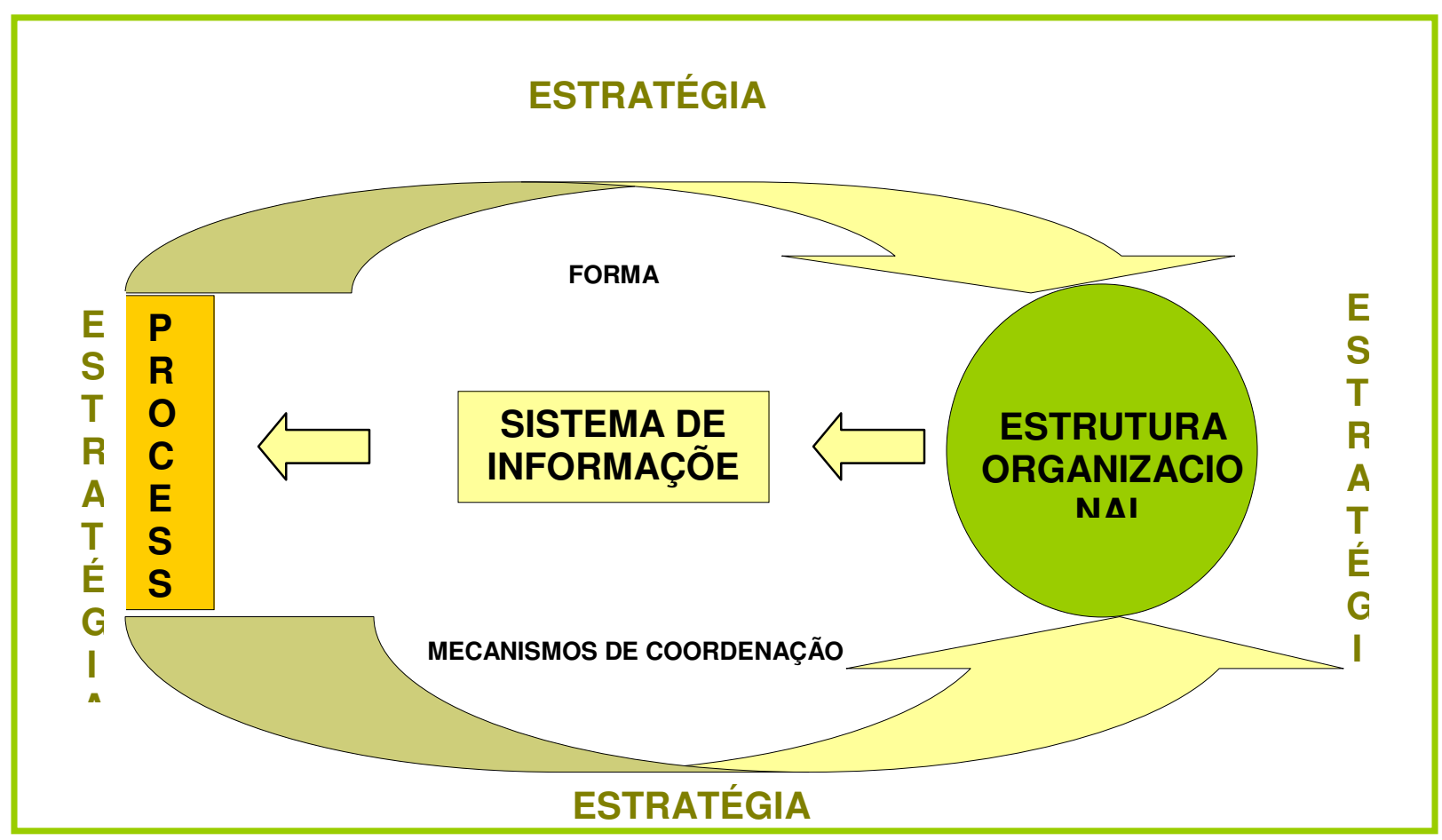

Figura 2.1 - 0 papel da estrutura organizacional no sistema de gestão da empresas

De acordo com esse mesmo autor, os mecanismos de coordenação tendem a mudar e a evoluir na medida do crescimento do número de pessoas, funções e/ou processos. A adoção da padronização do processo, dos outputs e das habilidades, normalmente levam à adoção simultânea do ajuste mútuo, ou seja, a utilização de procedimentos para realização e controle dos processos operacionais da empresa, o estabelecimento de padrões para avaliação dos produtos/serviços e contratação de profissionais especializados, levam à exclusão da supervisão. Para o caso da padronização das habilidades no qual o trabalho é realizado por especialistas que possuem domínio total sobre as operações, a inexistência de autonomia na tomada de decisão inviabiliza o processo produtivo. 
Quanto à forma, Mintzberg (2003) coloca que as empresas são compostas basicamente por cinco partes (núcleo operacional, cúpula estratégica, tecnoestrutura, núcleo de apoio e linha intermediária), independentemente da forma escolhida pela empresa para representar sua estrutura organizacional.

As empresas normalmente nascem do núcleo operacional, parte essa que envolve os membros que executam o trabalho básico relacionado à fabricação dos produtos ou à prestação de serviços. A cúpula estratégica possui responsabilidade global sobre a empresa e assegura que sua missão seja cumprida de forma eficaz, satisfazendo as necessidades dos que controlam ou detêm o poder. Na linha intermediária, situam-se os supervisores que utilizam a supervisão direta como mecanismo de coordenação para cumprir seu papel. A tecnoestrutura é responsável pela padronização do trabalho, dos produtos, pelo recrutamento e treinamento das equipes, pelo planejamento e controle da produção, e a unidade de apoio subsidia a realização do processo principal da empresa. As empresas não possuem, necessariamente, as cinco partes, pois as mesmas são acrescidas à organização conforme o seu crescimento e aumento da complexidade das operações.

\subsubsection{Aspectos relevantes quanto à definição da estrutura organizacional}

Para uma definição de estrutura organizacional coerente com os objetivos estratégicos da empresa, devem ser analisados alguns fatores denominados como contingenciais, segundo Maximiano (2004), Burton e Obel (1995), tais como: estilo de gestão predominante, ambiente, tecnologia, tamanho da empresa e estratégia, conforme ilustra a Tabela 2.10. São considerados fatores contingenciais aqueles que induzem às características da estrutura que retratam a complexidade das organizações. 


\begin{tabular}{|c|c|c|c|c|}
\hline $\begin{array}{c}\text { Tabela 2.10: } \\
\text { Fator } \\
\text { Contingencial } \\
\end{array}$ & Impacto & \multicolumn{3}{|c|}{ Influência quanto a escolha da estrutura } \\
\hline $\begin{array}{llr}\text { O estilo } & \text { de } & \text { gestão } \\
\text { do(s) } & \text { executivo(s) } \\
\text { principal(is) } & \text { da } \\
\text { empresa er percebido } \\
\text { pela } & \text { maneira } & \text { como } \\
\text { são } & \text { tomadas } & \text { as } \\
\text { decisões, } & \text { controladas } \\
\text { as } & \text { informações, } \\
\text { construídos } & \text { os } \\
\text { relacionamentos } & \text { no } \\
\text { ambiente de trabalho. }\end{array}$ & \begin{tabular}{||l|l|} 
Fator bastante relevante em \\
pequenas e e médias \\
empresas, onde ocorre alta \\
concentração de decisão na \\
pessoa do executivo principal.
\end{tabular} & \multicolumn{3}{|c|}{$\begin{array}{l}\text { O estilo de gestão do(s) executivo(s) } \\
\text { direciona }(m) \text { para estruturas com tendências: } \\
\text { Mecanicista ou Orgânicas; } \\
\text { Hierarquizadas, Burocráticas ou } \\
\text { Horizontais; } \\
\text { Flexíveis com Descentralização. }\end{array}$} \\
\hline $\begin{array}{l}\text { Tamanho definido em } \\
\text { função do número de } \\
\text { colaboradores, número } \\
\text { de produtorrou } \\
\text { serviços, total de } \\
\text { vendas, faturamento, } \\
\text { instalações r da } \\
\text { empresa. }\end{array}$ & \begin{tabular}{|lrr} 
Em função do crescimento, a \\
estrutura deve ser ajustada \\
ou até mesmo redesenhada \\
pararaviabilizar r r a \\
operacionalização rros do \\
novos processos & ou de \\
processos de & maior \\
complexidade. &
\end{tabular} & \multicolumn{3}{|c|}{$\begin{array}{l}\text { O crescimento das empresas leva ao } \\
\text { aumento do número de informações a serem } \\
\text { processadas, e este fato cria a necessidade } \\
\text { da descentralização na tomada de } \\
\text { decisão, enquanto que o estabelecimento de } \\
\text { estruturas complexas para organizações } \\
\text { menores acabam por dificultar o fluxo de } \\
\text { informações e o processo de trabalho. }\end{array}$} \\
\hline \multirow{4}{*}{$\begin{array}{|lrr|}\text { A } & \text { estrutura } \\
\text { organizacional } & \text { deve } \\
\text { estar alinhada } & \text { com a } \\
\text { estratégia } & \text { da } \\
\text { empresa para que } \\
\text { possam ser atendidas } \\
\text { as } & \text { demandas, } \\
\text { solicitações } & \text { e } \\
\text { oscilações res re do } \\
\text { ambiente no qual ela } \\
\text { está inserida. }\end{array}$} & \multirow{4}{*}{\begin{tabular}{||l} 
ambiente normalmente \\
influencia a tecnologia, \\
conhecimento e valores das \\
empresas; portanto, para \\
mais bem adequar-se às suas \\
solicitações através da \\
estratégia, é necessária a \\
compreensão em quatro \\
dimensões: \\
Estabilidade; \\
Complexidade; \\
Diversidade \\
Mercado; \\
Hostilidade.
\end{tabular}} & $\begin{array}{l}\text { Característic } \\
\text { a Ambiente do } \\
\text { Ambien }\end{array}$ & $\begin{array}{l}\text { Ambiente: } \\
\text { Segmento } \\
\text { da } \\
\text { Construçã } \\
\text { o Civil de } \\
\text { Edifícios }\end{array}$ & $\begin{array}{l}\text { Características } \\
\text { mais } \\
\text { apropriadas }\end{array}$ \\
\hline & & \begin{tabular}{|l|} 
Estabilidade \\
Complexidad \\
e
\end{tabular} & \begin{tabular}{|l|} 
Dinâmico \\
Alta
\end{tabular} & \begin{tabular}{|l|} 
Orgânica \\
Descentralizad \\
as
\end{tabular} \\
\hline & & Hostilidade & Alta & $\begin{array}{l}\text { Descentralizad } \\
\text { as e Orgânicas }\end{array}$ \\
\hline & & $\begin{array}{l}\text { Diversidade } \\
\text { de Mercado }\end{array}$ & Integrado & $\begin{array}{l}\text { Descentralizad } \\
\text { as e Orgânicas }\end{array}$ \\
\hline $\begin{array}{lr}\text { Sistema técnico, } \\
\text { quando analisado sob } \\
\text { o ponto de vista da } \\
\text { estrutura } & \\
\text { organizacional, } & \text { refere- } \\
\text { se a forma como } & \text { são } \\
\text { processados r os } & \text { os } \\
\text { recursos } & \text { para } \\
\text { transformá-los r em } \\
\text { produtos ou serviços. }\end{array}$ & $\begin{array}{l}\text { A estrutura organizacional } \\
\text { deve viabilizar a } \\
\text { maximização dos recursos } \\
\text { tecnológicos para a produção. }\end{array}$ & \multicolumn{3}{|c|}{$\begin{array}{l}\text { Quanto mais regular o sistema } \\
\text { técnico, mais formalizado o trabalho e mais } \\
\text { burocrática será a estrutura; } \\
\text { A automação do sistema técnico } \\
\text { transforma a estrutura burocrática em } \\
\text { orgânica. }\end{array}$} \\
\hline
\end{tabular}

Verifica-se que, além de analisar os fatores contingenciais apontados na Tabela 2.10 durante o projeto de estrutura organizacional, Vasconcellos e Hemsley (1986) argumentam que é necessário estabelecer os subsistemas de atividades (tipo de 
departamentalização), critérios de comunicação e critérios de autoridade. Para Maximiano (2004), a realização do processo de organização de forma eficaz deve pautar-se na cultura da empresa quando analisados fatores quanto a centralização ou descentralização, na complexidade e número de processos quando analisadas questões referentes à coordenação, formato da estrutura e hierarquia. O resultado da análise destes fatores é o detalhamento da estrutura organizacional.

\subsubsection{Tipos de Departamentalização}

De acordo com Vasconcellos e Hemsley (1986), departamentalização é o processo de agrupar indivíduos em unidades para que possam ser administrados.

Os principais critérios de departamentalização são o funcional, territorial ou geográfico, por produto, cliente, áreas de conhecimento, projeto funcional, projeto autônomo, estrutura matricial, processos e negócios. Na Tabela 2.11 estão relacionadas as características, limitações e aplicações de cada uma das estruturas citadas. 
Tabela 2.11: Tipos de departamentalização, segundo Maximiano (2004)

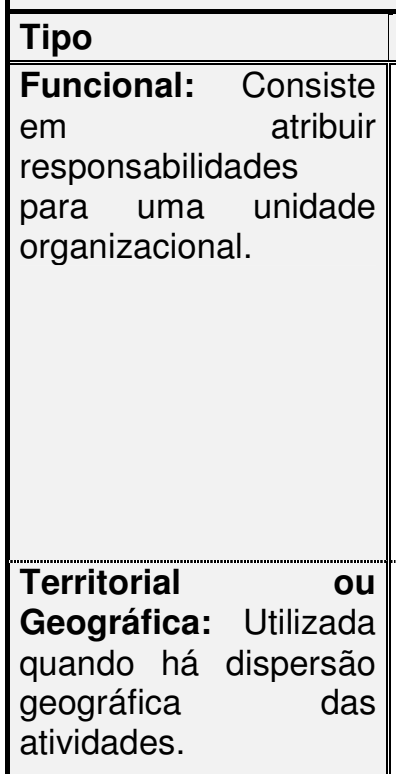

\section{Produto: Aplicada} quando a empresa trabalha com vários produtos/serviços e cada unidade de trabalho possui responsabilidade e autoridade sobre as operações relativas a um produto ou serviço.

Cliente: é apropriado quando a organização atende diferentes tipos de clientes com necessidades distintas.

\section{Areas}

Conhecimento:

consiste em criar departamentos para realizar atividades especializadas.

\section{Características}

Utilizada em empresas de grande ou pequeno porte.

O trabalho da empresa é organizado através de uma divisão sucessiva de atividades, onde é estabelecida a hierarquia da empresa.

O administrador principal tem controle da organização.

É mais apropriado em empresas que atuem na produção ou prestação de serviços de um único produto e em ambiente estáveis.

Caso não esteja bem estruturada, podem ocorrer confusões com relação às responsabilidades.

A excessiva especialização deste tipo de estrutura torna difícil a propagação do conhecimento.

Com o crescimento, a estrutura funcional pode tornar-se complexa, piramidal, feudal, ocasionando o distanciamento dos objetivos estratégicos.

Torna-se mais fácil o acompanhamento do desempenho de cada unidade regional no conjunto.

Os administradores e funcionários tornam-se especialistas em seus respectivos territórios.

Oferece grande potencial de treinamento de mão-de-obra, com a visão de diferentes culturas regionais.

Com a independência das unidades, pode ocorrer redundância de funções, e o conjunto todo torna-se ineficiente.

Se o mesmo produto/serviço for comercializado em diferentes regiões, a empresa pode sentir dificuldade em decidir pela descentralização ou centralização.

Pode ser utilizado em empresas industriais para estruturar linhas de produção, ou comerciais, para especializar o processo de prestação de serviços.

Possibilita a concentração de especialistas dentro da unidade de trabalho, aperfeiçoando a sua produção.

Preocupação com o produto estimula o aperfeiçoamento do seu processo; em contrapartida, pode ocasionar dificuldade para implementação de inovação tecnológica.

As responsabilidades em relação ao cliente são definidas e acompanhadas com maior facilidade.

Aprimoramento da competência dos funcionários no entendimento das necessidades do cliente e das formas de atendê-lo.

A focalização nos assuntos de um único cliente pode dificultar a propagação do aprendizado organizacional e limitar a possibilidade de experiências para os colaboradores.

Concentração de pessoas com mesma competência técnica que favorece o aprimoramento contínuo e o acúmulo de conhecimentos.

Tendência a autonomia, já que neste tipo de estrutura há grande contingente de especialistas; portanto, as empresas que possuem este tipo de estrutura são, geralmente, orgânicas.

A concentração de pessoas de mesma especialidade pode tornar difícil a comunicação e colaboração entre as áreas.

Continua na primeira 
Tabela 2.11: Tipos de departamentalização, segundo Maximiano (2004)

\begin{tabular}{|c|c|}
\hline Tipo & Características \\
\hline $\begin{array}{l}\text { Projeto Funcional: é } \\
\text { realizado dentro de } \\
\text { uma única área } \\
\text { funcional. }\end{array}$ & $\begin{array}{l}\text { Gerente de um projeto funcional monodisciplinar é o responsável direto } \\
\text { pelos resultados do projeto. } \\
\text { Certas organizações, especializadas em determinados tipos de projetos, } \\
\text { são conjuntos de projetos funcionais monodisciplinares. } \\
\text { Todos os recursos necessários à realização do projeto pertencem a uma } \\
\text { única especialidade ou área funcional. }\end{array}$ \\
\hline $\begin{array}{l}\text { Projeto Autônomo: } \\
\text { formado por uma } \\
\text { equipe multidisciplinar } \\
\text { temporária em regime } \\
\text { de dedicação } \\
\text { exclusiva. }\end{array}$ & $\begin{array}{l}\text { Um gerente é designado, as pessoas são escolhidas e a equipe é } \\
\text { separada da organização principal para concentrar-se na realização do } \\
\text { projeto. } \\
\text { O projeto autônomo é apropriado a empreendimentos estratégicos para } \\
\text { a empresa. }\end{array}$ \\
\hline $\begin{array}{l}\text { Matricial: formada por } \\
\text { uma equipe } \\
\text { multidisciplinar } \\
\text { temporária } \\
\text { colaboradores cujos } \\
\text { poderão dedicar-se a } \\
\text { outros projetos. }\end{array}$ & $\begin{array}{l}\text { A equipe é formada por colaboradores das áreas funcionais, } \\
\text { "emprestados" ao projeto por período determinado. } \\
\text { Cada um dos especialistas ligados ao projeto mantém sua ligação e } \\
\text { compromissos com o departamento de origem. } \\
\text { Combina a especialização e concentração de conhecimentos da } \\
\text { estrutura funcional e favorece a orientação para algum tipo de resultado ou } \\
\text { problema a ser resolvido. } \\
\text { A dupla subordinação ocasiona, em alguns casos, a falta de poder } \\
\text { formal. }\end{array}$ \\
\hline $\begin{array}{l}\text { Processos: é uma } \\
\text { cadeia horizontal de } \\
\text { processos orientando } \\
\text { todas as funções para } \\
\text { a solução de um } \\
\text { problema. }\end{array}$ & $\begin{array}{l}\text { As funções trabalham de forma coordenada, por meio de comunicação } \\
\text { entre todos os departamentos envolvidos, para aumentar eficiência ao longo } \\
\text { do processo. }\end{array}$ \\
\hline
\end{tabular}

A seleção de uma estrutura organizacional requer compreensão do trabalho e tipos de atividades necessárias para alcançar o objetivo da empresa. Analisando as empresas de projeto de edifícios de forma geral, verifica-se que o seu surgimento e posterior funcionamento ocorre em função da contratações para desenvolvimento de soluções projetuais. Normalmente são as empresas de pequeno porte que desenvolvem apenas uma especialidade de projeto (arquitetura, estrutura, instalações prediais, etc.) e, na maior parte das vezes, os profissionais técnicos destas empresas são alocados para o desenvolvimento simultâneo de diferentes projetos. As funções administrativas (financeiro, contábil, comercial, recursos humanos, etc.) são responsáveis pelo processamento das atividades de todos os projetos da empresa. 


\subsection{Processo de Projeto}

Melhado (1994) define o projeto a partir de uma visão fundamentada pela qualidade como atividade de concepção de produto ou serviço, e pode ser entendido como um processo que utiliza um conjunto de dados de entrada e, ao final, deve garantir como dados de saída um grupo de soluções que respondem às necessidades dos clientes a quem o edifício se destina.

De acordo com Fabrício, Baía e Melhado (1998), o processo de projeto na construção civil é composto por várias especialidades (arquitetura, estruturas, sistemas prediais, etc.), as quais desenvolvem soluções em nível crescente de detalhamento, cumprindo diferentes etapas de projeto. Esta etapa está inserida no ciclo de vida do empreendimento edificação, que vai desde a concepção do produto edifício, passando pelo desenvolvimento da atividade projetual nas suas diversas especialidades, construção, uso e, finalmente, revitalização ou descarte.

Nesse sentido, Melhado et al. (2005) inserem o projeto no contexto do empreendimento edifício, identificando, durante o seu ciclo de vida, algumas interfaces que envolvem o desenvolvimento da atividade projetual.

A primeira ocorre na fase de concepção do empreendimento, onde é desenvolvido o programa de projeto e onde acontece a colaboração, a concepção do negócio, a especificação das necessidades dos clientes e a criação e desenvolvimento do produto.

A segunda interface ocorre na fase de desenvolvimento dos projetos do produto e envolve todos os projetistas das diversas especialidades. Esta interface, segundo o mesmo autor, se relaciona com a busca de uma efetiva coordenação na atuação dos projetistas.

Já a terceira interface relaciona-se com a construtibilidade dos projetos e com a elaboração dos projetos para produção, de forma a resolver antecipadamente o processo de execução de acordo com as especificações do produto. 
Por fim, a quarta e quinta interfaces, caracterizadas como retroalimentação execução-concepção e retroalimentação uso-concepção. Ambas configuram-se pela retroalimentação do processo de execução e do uso para subsidiar novos projetos, de forma a considerar os resultados e experiências de empreendimentos anteriores.

Segundo Melhado (2004), o agente principal dessa fase do ciclo de vida do produto edificação - o projetista, deve ser capaz de traduzir os objetivos e restrições em alternativas de soluções funcionais e tecnológicas com desempenho equivalente, de selecionar a alternativa que demanda o mínimo de recursos, e de traduzir as opções de projeto em nível de desempenho esperados para o produto final.

Para o autor, os diferentes agentes envolvidos no empreendimento apresentam atuação fragmentada e interesses próprios, às vezes divergentes, quanto às características e objetivos do empreendimento. O processo de projeto é considerado como uma fase estratégica do empreendimento em relação aos gastos de produção e à agregação de valor ao produto e, do ponto de vista organizacional, o projetista não é um agente independente, autônomo - sua atividade só faz sentido no contexto do empreendimento do qual seu projeto faz parte, e em cuja equipe são estabelecidas as relações temporárias com outros agentes, como o empreendedor, o construtor e o usuário.

De acordo com Fabrício (2002), é necessário destacar que o projeto de edifício ocorre em um dado ambiente social e produtivo, e visa atingir um propósito, devendo respeitar uma série de regulamentações e restrições impostas pelas necessidades dos clientes e usuários, pelas capacidades produtivas dos construtores, pela legislação e pelo estado da arte do conhecimento humano. Dessa forma, o autor conclui que o projeto do edifício pode ser considerado um subprocesso industrial circunscrito em um dado ambiente produtivo. 


\subsubsection{O processo de projeto no contexto da empresa}

Com objetivo de organizar o processo de projeto dentro da empresa e torná-lo "manufaturável", Brookfield, Emmit, Hill e Scaysbrook (2005) propõem a utilização dos conceitos do lean design, através da coordenação dos fluxos de trabalho e informações, desenvolvendo o projeto de forma a produzir soluções tecnológicas e de funcionalidade.

Para os autores, o lean design pode ser encarado tanto como um processo de gestão, quanto como processo tecnológico. Para a perfeita operacionalização dos princípios propostos, tanto do ponto de vista de gestão quanto de tecnologia, faz-se necessária a estruturação do sistema comunicação para a condução do processo de projeto. Como processo de gestão, deve ser estruturado partindo das seguintes premissas:

- Compreender os valores intrínsecos e como serão agregados ao projeto.

- Identificar os valores do cliente.

- Estabelecer o trabalho através de fluxos, de forma a reduzir e até remover definitivamente desperdícios e retrabalhos.

- Fazer com que a informação esteja disponível a tempo de ser utilizada.

- Procurar atingir a perfeição, reconhecendo que a melhoria necessita de constante empenho.

Como processo tecnológico, o lean design parte das seguintes premissas:

- Modularidade.

- Facilidade para produção.

- Racionalização e redução do número de componentes.

- Redução dos tempos de produção. 
- Redução da complexidade do produto.

- Redução do número de operações produtivas.

- Qualidade e confiabilidade.

No Brasil, destaca-se como principal iniciativa setorial para o estabelecimento de um fluxo de trabalho estável e padronizado a ser seguido durante a elaboração dos projetos de um empreendimento, a criação dos diversos Manuais de Escopo de Projetos, ${ }^{2}$ trabalho esse conduzido pelas entidades que representam os profissionais de projeto (ABECE, ABRASIP, AsBEA, AGESC e ABRAVA, seguidas da ANP, ABAP e ABRIESP).

Segundo as entidades, o desenvolvimento desses manuais objetiva a implantação de uma política de melhoria contínua da qualidade na cadeia produtiva e de relações éticas entre os seus diversos intervenientes, pois a definição prévia do escopo dos serviços para a elaboração dos diversos projetos que compõem um empreendimento deve preceder o inicio da elaboração de qualquer um dos projetos.

O conceito proposto nos manuais de escopo parte da premissa da complexidade da atividade de projeto, que envolve, além da atividade projetual em si, diversas interfaces com outras especialidades técnicas, além da contínua e crescente exigência por parte da indústria da construção civil em se apresentar projetos coerentes com os princípios de racionalização, planejamento e controle de obras. Os materiais produzidos podem e devem ser utilizados como referência para todos os que se relacionam com o processo de desenvolvimento imobiliário, possibilitando conhecimento pleno das diversas etapas do projeto contratado.

Os manuais (arquitetura, estrutura, instalações elétricas e hidráulicas, arcondicionado, automação, coordenação de projetos, esportes e paisagismo) são estruturados individualmente a partir da seqüência de atividades envolvidas em cada uma das disciplinas. Cada uma das atividades contém os dados necessários para

\footnotetext{
${ }^{2}$ Os Manuais de Escopo de Projetos de arquitetura, estrutura, instalações elétricas e hidráulicas, arcondicionado, automação, coordenação de projetos, esportes e paisagismo estão disponíveis no site: http://www.manuaisdeescopo.com.br
} 
sua realização, definição de responsabilidades e os produtos gerados na etapa, bem como os possíveis documentos produzidos.

Como instrumento de gestão, o manual pode ser utilizado pela empresa de projeto como referencial para a estruturação do fluxo de trabalho em cada uma das contratações, e para o posterior planejamento e definição de ferramentas de controle do processo interno, tais como listas de verificações e ferramentas de controle para os recursos utilizados (tempo, pessoas, tecnologia, investimentos financeiros, etc.).

\subsubsection{Os princípios da administração de projetos}

Os princípios da administração de projetos aqui referenciados, referem-se à metodologia do "Project Management".

Partindo dessa metodologia, Maximiano (2002) define "projeto" como uma sequência de atividades temporárias que tem por objetivo fornecer um produto singular : produto físico (casa, rodovia, veículos, máquinas e equipamentos em geral), conceito ( roteiros de filmes, mapas, sistemas, organogramas, desenhos) e eventos.

Para o autor, em essência projeto é qualquer atividade que se decide administrar como projeto e para que realmente seja caracterizado como tal, as seguintes questões devem ser respondidas:

- A atividade tem começo, meio e fim programados?

- A atividade é diferente das atividades de rotina?

- A solução do problema envolve muitas variáveis?

- A solução do problema é desconhecida?

- A solução do problema deve ser apresentada dentro de um prazo definido?

- A solução do problema requer competências e recursos multidisciplinares? 
- A solução do problema é importante para a organização ?

- A solução do problema ou atividade envolve um cliente importante da organização?

Se feitas tais questões com objetivo de caracterizar o processo de projeto de construção civil como "project", todas as questões terão a resposta positiva. Portanto conclui-se que a aplicação dos conceitos da administração de projetos é adequada para a estruturação e gestão do processo de projeto.

Nesse sentido, no decorrer desse item serão discutidos os conceitos de administração de projetos e baseadas nessa discussão, serão propostas no item 4.2, recomendações para a gestão do processo de projeto com objetivo de estruturar, organizar, controlar e retroalimentar tal processo.

De acordo com Kerzner (2006), a administração de projetos pode ser definida como planejamento, programação e controle de uma série de tarefas integradas de forma a atingir seus objetivos com êxito, para benefício dos participantes do projeto. Para o autor, administrar projetos de forma eficaz exige interação constante entre a equipe, permitindo a melhoria da coordenação e comunicação entre todos os envolvidos.

Para Maximiano (2002), a essência da administração de um projeto é o planejamento e a execução das atividades de seu ciclo de vida (idéia, desenho, desenvolvimento e entrega), para que o produto seja entregue ao final. De acordo com este autor, administrar um projeto compreende planejar, organizar, executar e controlar as fases de seu ciclo de vida.

\subsubsection{Plano do Projeto}

Segundo Leintz e Rea (2001), objetiva-se, com a elaboração do plano de projeto, determinar como acontecerá a gestão da informação, definir os orçamentos e cronogramas iniciais, estabelecer vínculo entre o plano do projeto com outros 
projetos desenvolvidos simultaneamente e envolver a equipe que o conduzirá em todo o seu ciclo de vida.

\subsubsection{Formação da Equipe}

De acordo com Maximiano (2002), o tamanho de uma equipe de projetos pode variar de uma única pessoa até centenas ou milhares de pessoas, para o caso de produtos complexos como aviões ou grandes obras; no entanto, mesmo para os projetos estritamente individuais, sempre há necessidade de trabalho em equipe, que envolve colaboração e entendimento com outros.

Segundo o autor, na administração de projetos, assim como em qualquer outra situação, as virtudes desejáveis de uma equipe, tais como coesão, estado de motivação, organização e comunicação adequada, confrontam-se com as dificuldades que os grupos sempre apresentam, como por exemplo, a coesão excessiva que pode tornar o grupo refratário a idéias externas, ou ainda a falta de coesão, que faz com que cada indivíduo trabalhe isoladamente sem levar em consideração o grupo.

Outro aspecto negativo que pode envolver um grupo de trabalho é a conformidade social, que é o processo pelo qual um integrante do grupo tende a concordar com uma proposição quando percebe que os demais já concordaram. O processo de conformidade social pode ocorrer tanto em função de coesão excessiva, quanto em função da análise superficial de um problema.

O processo de formação de uma equipe inicia-se com a indicação de um líder (coordenador ou gerente do projeto). Segundo Meredith e Mantel Jr. (2003), é este indivíduo que tomará para si a responsabilidade pelo planejamento, implementação e finalização do projeto. Na Tabela 2.12 estão indicadas e comentadas as características essenciais do líder de projeto, tais como: disponibilidade, credibilidade, sensibilidade, liderança e estilo de gestão 


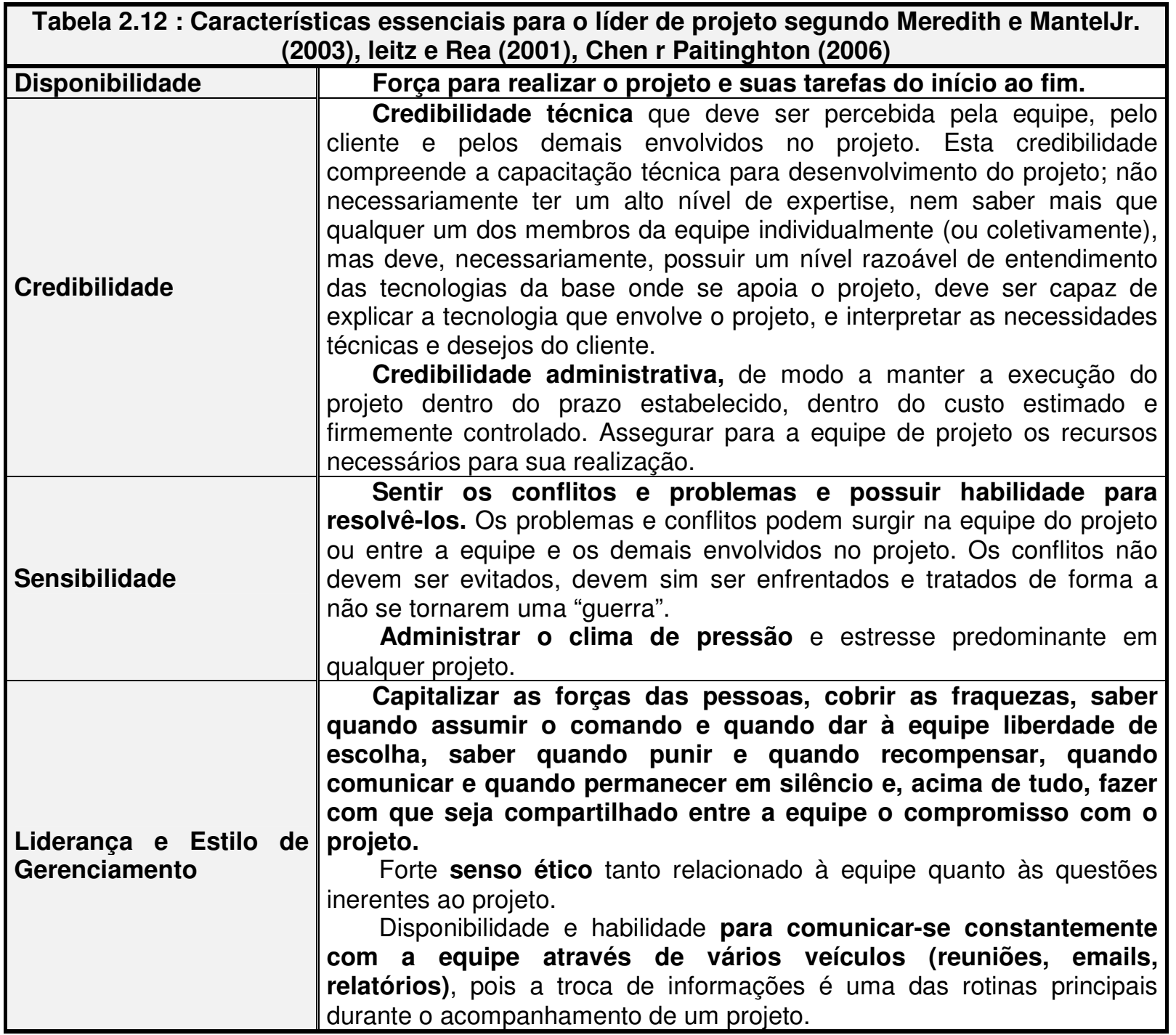

Quanto à indicação dos demais membros que farão parte da equipe, segundo Maximiano (2002), devem ser levadas em consideração não apenas as afinidades, mas as habilidades, competências, a experiência e o potencial de contribuição para os objetivos do projeto, e é fundamental a criação de uma identidade de grupo, clima de abertura intelectual, comunicação com o mundo externo e treinamento.

Para esse autor, o desenvolvimento de uma identidade de grupo está relacionado à interação frequente entre os componentes do grupo, facilitando, assim, os processos de administração, reforçando o sentido do grupo e os atributos do alto desempenho. O clima de abertura intelectual, além de estimular a criatividade, contribui para a participação do grupo nos processos decisórios, e promove a aprendizagem organizacional. A comunicação com o ambiente externo ao projeto, além de evitar refratariedade, como já colocado, contribui para a garantia da qualidade no projeto. 
Com relação à identificação da necessidade de treinamento, esta pode estar relacionada à técnica de gestão de projetos ou à execução do projeto propriamente dito.

O Guia PMBOK (2004) coloca que o processo de gerenciamento da equipe de projeto inclui:

- Planejar os recursos humanos: identificar e documentar as funções, responsabilidades e relações hierárquicas no projeto.

\section{- Contratar ou mobilizar a equipe de projeto.}

\section{- Desenvolver a equipe de projeto.}

- Gerenciar a equipe de projeto: acompanhar o desempenho de membros da equipe e retorno, resolução de problemas e coordenação de mudanças para melhorar o desempenho do projeto.

\subsubsection{Estrutura do Projeto}

De acordo com Tiner (1985), a subdivisão do projeto em categorias de trabalho é extremamente importante, pois confere ao seu gestor a facilidade para planejar e controlar o projeto de forma mais detalhada e ativa.

O nível de detalhamento e subdivisão do projeto depende da atividade que será desenvolvida e da quantidade e nível de detalhamento que o gestor necessita para controlar adequadamente ao projeto. Esta subdivisão é denominada de Estrutura Analítica de Projeto - EAP, e, de acordo com Globerson (1994), o conteúdo de um projeto é identificado através da estrutura analítica de projeto, ou seja, é a "espinha dorsal" do planejamento, execução e controle do projeto. O autor observa que não existe uma estrutura única para cada tipo de projeto, e este detalhamento deve ser realizado o quanto antes, pois o gestor precisa estar consciente de que esta ferramenta estará constantemente exposta a modificações e que contribuirá de forma significativa para o sucesso do projeto. 
2.3.2.4 Planejamento do projeto: composição orçamentária, tempo e alocação de recursos

Segundo Meredith e Mantel Jr. (2003), a composição orçamentária de um projeto deve levar em consideração os tipos de recursos necessários para a sua realização, a quantidade, quando serão utilizados e o custo individualizado de cada um deles, e que a incerteza faz parte de qualquer previsão, embora algumas apresentem-se em menor grau. Assim, cada empresa possui sua regra geral no que se refere à estimativa de custos, as quais normalmente trazem a experiência prática adquirida pelos gestores ao longo do tempo; no entanto, a composição orçamentária de um projeto não pode depender somente da tradição e experiência acumuladas, pois toda empresa possui suas idiossincrasias. Para tanto, conforme observa-se na Figura 2.2, os autores propõem dois métodos para elaboração do orçamento de um projeto: de baixo para cima e de cima para baixo.

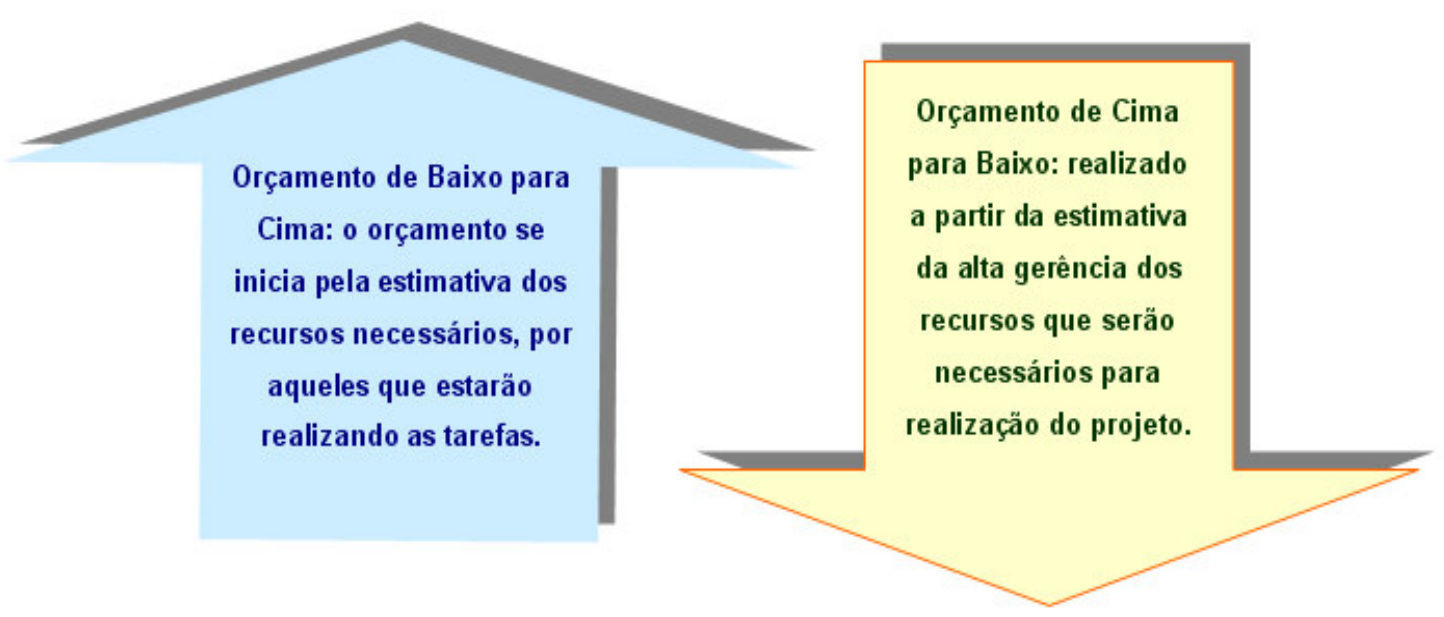

Figura 2.2 - Métodos para elaboração da composição orçamentária de um projeto, segundo Meredith e Mantel Jr. (2003)

A realização do orçamento de um projeto possui ligação direta com a definição dos recursos a serem utilizados na sua execução. De acordo com Maximiano (2002), a primeira etapa na elaboração de um orçamento é a elaboração da relação dos recursos necessários para a realização do projeto, e estes recursos geralmente classificam-se em quatro tipos: 
- Colaboradores: funcionários próprios e serviços eventualmente contratados, e dividem-se em quatro categorias: coordenação, pessoal técnico, pessoal sênior e pessoal administrativo.

- Material permanente: bens, equipamentos e instalações a serem adquiridos, construídos ou alugados.

- Material de consumo: combustível, materiais de escritório, peças de reposição.

- Serviços de terceiros: viagens, hospedagem, alimentação, transporte, contratação de serviços especializados, etc.

O planejamento da realização das tarefas de um projeto ao longo do tempo geralmente é realizado através de um cronograma que, segundo Meredith e Mantel Jr. (2003), significa a conversão de seu plano de ação em uma programação operacional e, como tal, funciona como base para controle das atividades desenvolvidas durante o projeto.

De acordo com o Guia PMBOK (2004), o processo do gerenciamento de um projeto inclui as seguintes atividades: definição das atividades, sequenciamento das atividades, estimativa de recursos das atividades, desenvolvimento do cronograma e controle do cronograma.

A definição das atividades do projeto, o seu sequenciamento com estabelecimento das dependências entre as diversas atividades, a identificação dos recursos necessários para a realização de cada tarefa e a estimativa de duração de cada atividade são passos fundamentais na elaboração do cronograma de projeto e posterior controle. Segundo Meredith e Mantel Jr. (2003), o orçamento e o planejamento do tempo constituem as duas principais ferramentas para 0 gerenciamento do projeto. 
2.3.2.5 Planejamento da Comunicação, tratamento da informação, qualidade e controle do processo de projeto

O Guia PMBOK (2004) trata o gerenciamento das comunicações como a área de conhecimento que emprega os processos necessários para garantir a geração, a coleta, a distribuição, o armazenamento, a recuperação e a destinação final das informações sobre o projeto, de forma oportuna e adequada. Segundo o manual, todos os envolvidos no projeto devem entender como as comunicações afetam o projeto como um todo, e apontam os seguintes aspectos:

- Planejamento das comunicações: determinação das necessidades de informações e comunicações das partes interessadas no projeto. Nesta etapa, é fundamental identificar quem precisa da informação e qual informação precisa, quando precisará, como será fornecida e por quem será fornecida.

- Distribuição das informações: colocação das informações necessárias à disposição das partes interessadas no projeto no momento adequado.

- Relatório de desempenho: coleta e distribuição das informações sobre o desempenho. Isso inclui a elaboração de relatórios de andamento, medição e progresso e previsão do projeto.

- Gerenciar as partes interessadas: gerenciamento das comunicações, a fim de satisfazer os requisitos das partes interessadas no projeto e resolver problemas com elas.

Segundo Maximiano (2002), o planejamento da qualidade consiste na definição das características do produto, com base na análise de necessidades. De acordo com o autor, a qualidade abrange dois tipos de características ou especificações: as especificações funcionais e técnicas. As especificações funcionais traduzem as necessidades e expectativas do cliente em termos de desempenho que o produto deverá alcançar, enquanto que as especificações técnicas nascem das especificações funcionais, e descrevem as características do produto em termos de seus atributos técnicos. 
De acordo com Bateman e Snell (1998), planejamento é o processo consciente e sistemático de tomar decisões sobre objetivos e atividades que uma pessoa, um grupo, uma unidade de trabalho ou uma organização buscarão no futuro. Deve prover aos indivíduos e unidades de trabalho um mapa claro a ser seguido em suas atividades futuras, ao mesmo tempo em que este mapa pode levar a considerações circunstanciais únicas e mutantes.

Os autores colocam que o processo de planejar é similar ao de tomada de decisão empresarial e deve seguir alguns passos como mostra o esquema de Figura 2.4.

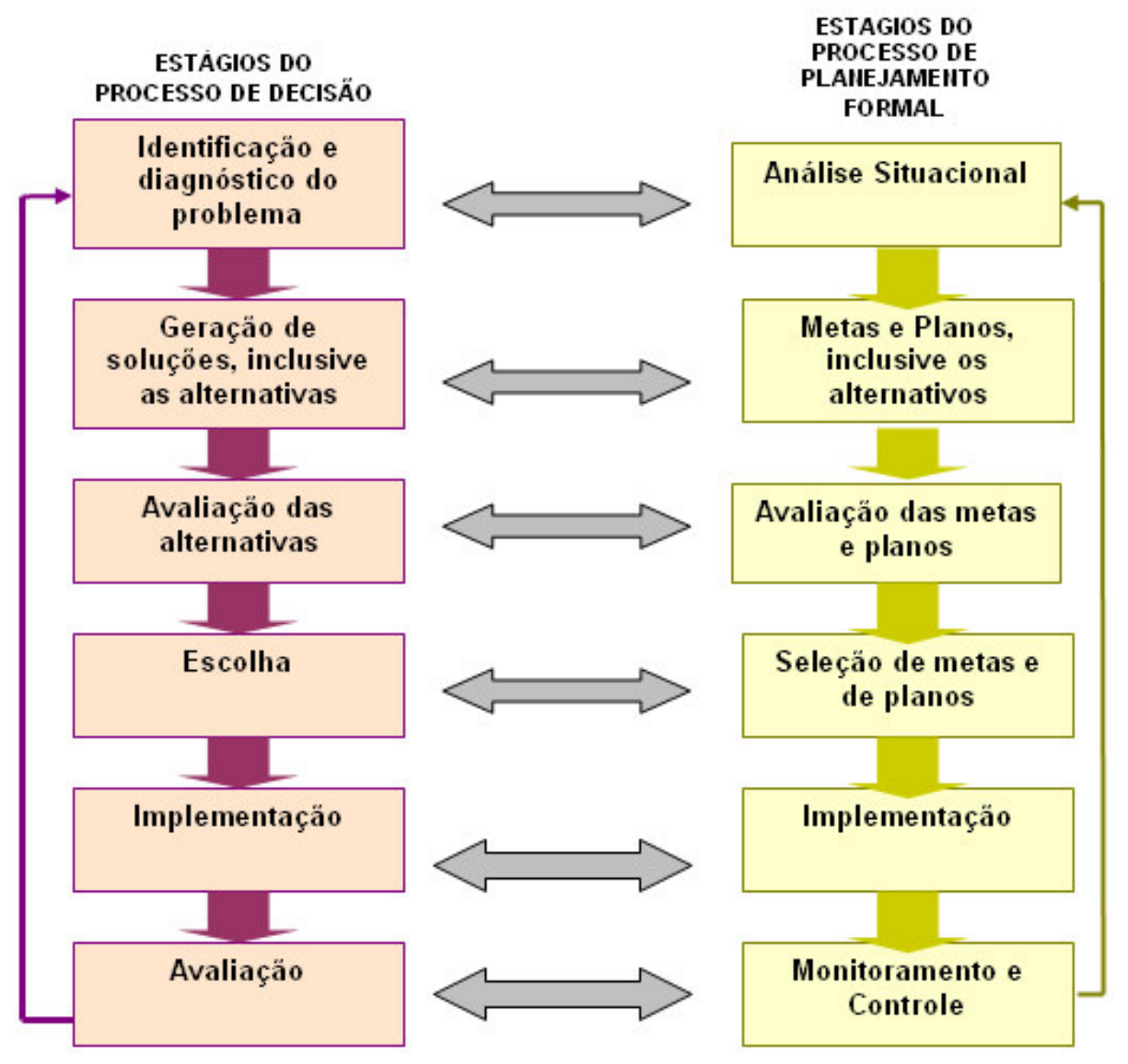

Figura 2.4 - Similaridades entre o processo de tomada de decisão e o processo de planejamento, segundo Bateman e Snell (1998) 
A elaboração do planejamento estratégico envolve a tomada de decisões sobre os objetivos e estratégias de longo prazo, possui uma orientação externa envolvendo as partes principais da organização, e normalmente é desdobrada para o restante da empresa através do planejamento tático e operacional, que envolvem períodos de tempo menores, mas relevantes para uma parte definida da empresa.

Segundo Steiner (1979), a essência do planejamento estratégico está em realizar uma sistemática identificação de oportunidades e ameaças futuras, combinando tais informações com outros dados relevantes procedentes da própria empresa, de forma a subsidiar a tomada de decisões para explorar as oportunidades e superar as barreiras. Para o autor, planejar significa desenhar um futuro desejado e identificar caminhos para alcançá-lo.

O processo do planejamento estratégico evoluiu muito dos anos 60 até a atualidade, pois enfatizava uma abordagem "de cima para baixo", na qual a alta direção da empresa desenvolvia planos para o restante da organização, que tinha a responsabilidade de executá-los.

De acordo com Bateman e Snell (1998), empresas e consultorias inovaram uma série de técnicas analíticas e abordagens de planejamento, muitas das quais se tornaram modismos empresariais e foram utilizadas de forma inadequada, e conduziram a conclusões estratégicas e avaliações simplistas. Verificou-se que a prática de planejar estrategicamente de "cima para baixo" ocasionava no restante da empresa a sensação de alienação, levando ao baixo comprometimento para com o sucesso da organização.

Em função dessa constatação, iniciou-se, na década de 90, um movimento que tinha como objetivo envolver toda a empresa no processo de planejamento estratégico e, em decorrência desta tendência, surgiu um novo termo para o processo de planejamento estratégico : Administração Estratégica.

A administração estratégica, conforme observa-se na Figura 2.5, integra o planejamento estratégico e a administração num único processo, tornando o planejamento estratégico um processo contínuo. 


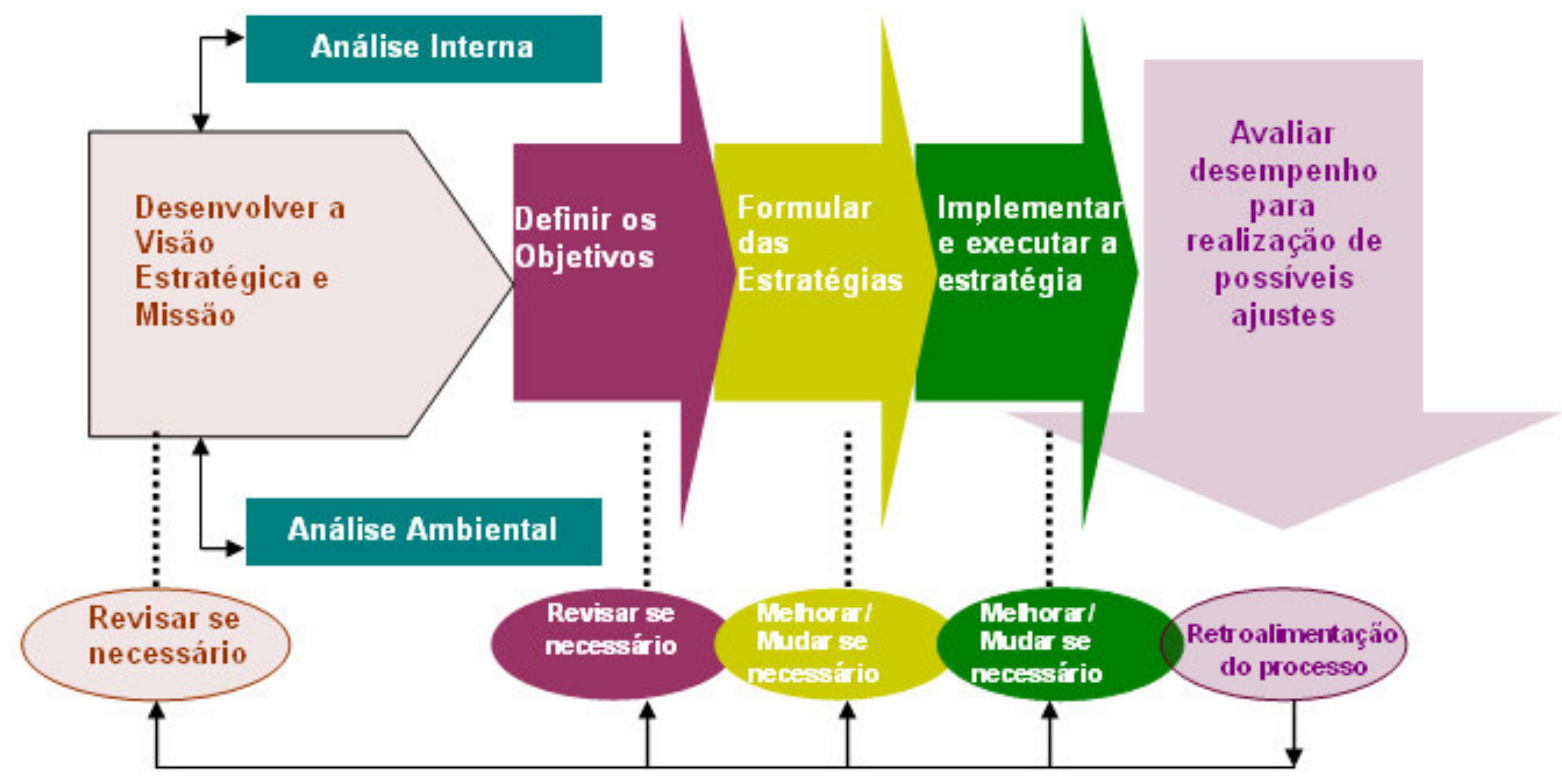

Figura 2.5 - Esquema adaptado do processo de administração estratégica, de acordo com Thompson, Strickland (2001) e Fischman, Almeida (1991)

\subsubsection{Estratégia Empresarial}

Para as empresas, segundo Oliveira (1991), a estratégia está relacionada à arte de utilizar adequadamente os recursos físicos, financeiros e humanos, tendo em vista a minimização dos problemas e a maximização das oportunidades, ajustando-se ao seu ambiente.

A estratégia não é o único fator determinante do sucesso da empresa, pois deve estar alinhada a competência dos gestores e colaboradores da empresa, e a condições ambientais favoráveis. A adoção de estratégias coerentes com ambiente, levando em consideração suas possibilidades e limitações, geram ganhos e maior controle da empresa durante às instabilidades ambientais.

Para o estabelecimento de estratégias empresariais eficazes, é necessário o prévio conhecimento das expectativas dos grupos significativos que cooperam para assegurar a existência contínua da empresa (clientes, administradores, 
investidores), tendências tecnológicas e ações governamentais que poderão influenciar o rumo dos negócios da empresa. O objetivo maior do estabelecimento das estratégias empresariais é proporcionar para a empresa uma posição competitiva de mercado e sustentabilidade para os seus negócios, e não deve ser considerada como um plano fixo ou determinado, mas um esquema orientador dentro de um fluxo de decisões.

Antes de estabelecer sua estratégia de atuação, a empresa deve refletir e registrar a sua visão estratégica e missão. De acordo com Thompson e Strickland (2001), a visão estratégica define as perspectivas futuras da empresa em relação à tecnologia, aos clientes, às vendas de produtos, à localização e ao desenvolvimento de competências, e deve ter como prerrogativa que tipo de organização a atual gestão pretende criar no futuro, dentro de um horizonte estratégico pré-estabelecido, enquanto que a missão é focada no comportamento e na forma de gestão presente na empresa, ou seja, quais os produtos com que a empresa trabalha, qual mercado abrange, quais as competências que possui e quais tecnologias são utilizadas.

Para estes mesmos autores, as estratégias das empresas normalmente são definidas em função de dois componentes: as estratégias planejadas e as estratégias reativas. As estratégias planejadas são aquelas provenientes de pesquisa de expectativas de mercado, geralmente vinculadas às inovações tecnológicas; as estratégias reativas estão relacionadas às imposições de mercado, restrições legais ou até mesmo mobilizações governamentais que possam influenciar nas operações das empresas ou de seus produtos.

Conforme ilustra a Figura 2.6, acrescenta-se a esta linha de pensamento a componente formada pelas estratégias vigentes válidas, ou seja, estratégias que proporcionaram, até o momento, uma posição competitiva no mercado, as quais a empresa considera fundamentais no delineamento final de sua estratégia. 


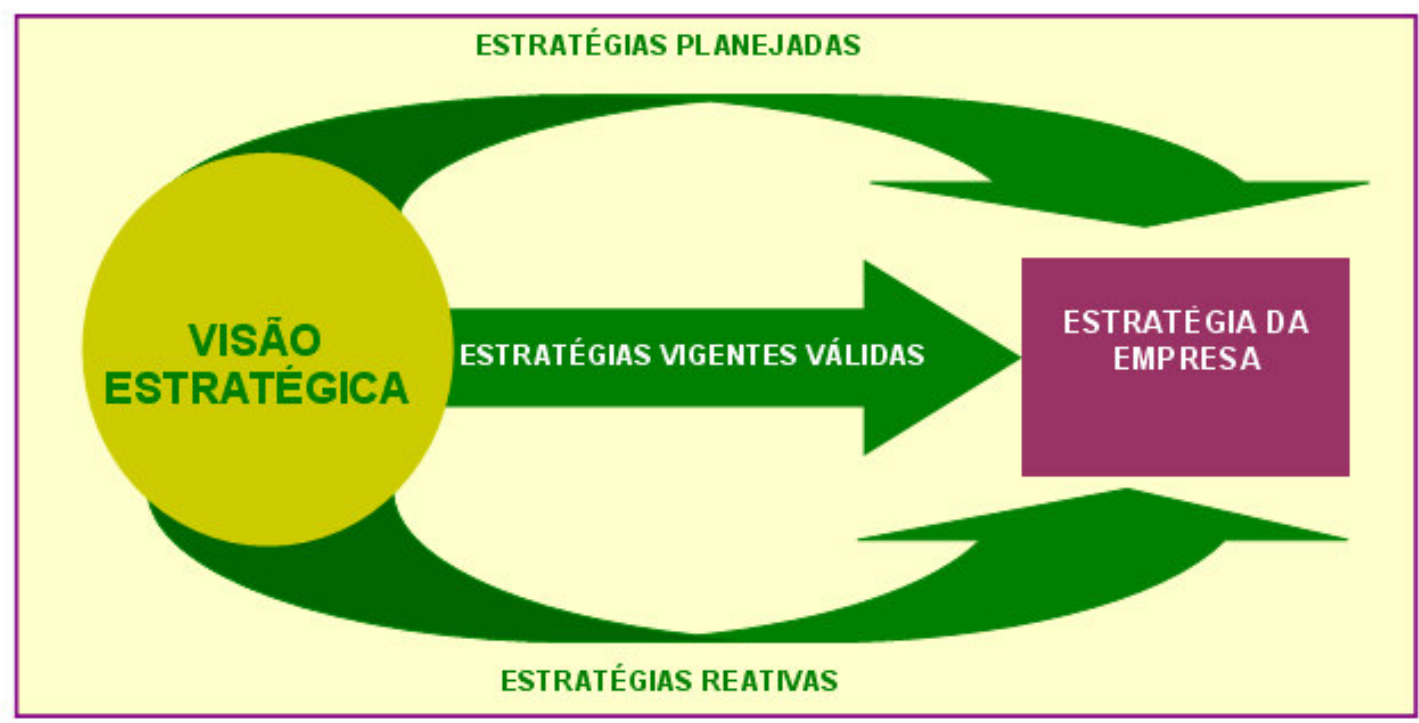

Figura 2.6 - Componentes da Estratégia Empresarial, adaptado de Thompson, Strickland (2001)

A estratégia que situa a empresa numa posição competitiva na indústria ou no setor onde atua é denominada por Porter (1989) como estratégia competitiva, definida pelo autor como a combinação dos fins (metas) que a empresa busca e dos meios (políticas).

Para Oliveira (1991), quando analisados os tipos de estratégia mais adequados para uma empresa, é necessário, antes, que se considerem as formas de classificá-las, conforme demonstrado na Tabela 2.13.

Tabela 2.13: Classificação proposta por Oliveira (1991) quanto às possíveis estratégias empresariais

\section{Quanto à amplitude}

Macroestratégia: Ação que a empresa adotará com relação ao ambiente.

Estratégia Funcional: Relacionada à forma de atuação de uma área funcional da empresa, normalmente relacionada ao nível tático.

Microestratégica : Relacionada à forma de atuação no nível operacional.

\section{Quanto à qualidade dos resultados}

Estratégias fortes: Impactantes para a empresa.

Estratégias fracas: Cujos resultados são mais amenos para empresa.

\section{Quanto ao enfoque}

Estratégias pessoais: Relacionados a valores, proteções contra ambiente hostil, técnicas para lidar com pessoal.

Estratégias empresariais: Representa a ação da empresa com relação ao ambiente. 
Tabela 2.13: Classificação proposta por Oliveira (1991) quanto às possíveis estratégias empresariais

Quanto à postura: estabelecida de acordo com a situação da empresa, ou seja, está voltada para a sobrevivência, manutenção, crescimento ou desenvolvimento, e é limitada pela missão e visão, relação (positiva ou negativa) entre as oportunidades e ameaças, e relação (positiva ou negativa) entre pontos fortes e fracos

Baseada na postura $\checkmark$ Redução de Custos: redução de todos os custos possíveis para que a de sobrevivência: empresa possa subsistir.

esta estratégia $\checkmark$ Desinvestimentos: retirar investimentos de produtos ou serviços menos somente deve se interessantes para a empresa com objetivo de não prejudicar o negócio adotada pela empresa original.

em caso extremo. $\quad \checkmark \checkmark$ Liquidação de negócios: finalização dos negócios da empresa.

Baseada na postura $\checkmark$ Estratégia da estabilidade: a empresa busca o equilíbrio entre receitas de manutenção: e despesas de forma a manter um estado de equilíbrio mercadológico.

postura defensiva $\checkmark$ Estratégia de nicho: a empresa procura dominar o segmento de adequada para mercado onde ela atua concentrando seus esforços para preservar a empresas que estão vantagem competitiva.

enfrentando ou que $\checkmark$ Estratégia de especialização: concentração de esforços em uma única \begin{tabular}{l|l} 
enfrentarão & atividade.
\end{tabular}

dificuldades.

Baseada na postura $\checkmark$ Estratégia de inovação: antecipa-se aos concorrentes através do do crescimento: desenvolvimento tecnológico e do lançamento de novos produtos.

adequada quando a $\checkmark$ Estratégia de internacionalização: estende suas atividades para fora empresa verifica das fronteiras do país.

situações favoráveis $\checkmark$ Estratégia de Joint Venture: entra num novo mercado/negócio que podem se associado a uma outra empresa.

transformar em $\checkmark$ Estratégia de expansão: investimento para aumentar a produção e oportunidades. atuação mercadológica.

$\checkmark$ Estratégia de fusão: junção de duas ou mais empresas no mesmo negócio. Neste caso, as empresas podem ser dissolvidas, os direitos e obrigações são combinados e novas ações são emitidas.

Baseada na postura $\checkmark$ Estratégia de desenvolvimento de mercado: a empresa procura novos de desenvolvimento: mercados para seus produtos.

adequada quando a $\checkmark$ Estratégia de desenvolvimento de produto ou serviço: empresa empresa verifica a busca o aumento das vendas através do desenvolvimento de novos possibilidade de se produtos.

desenvolver através $\checkmark$ Desenvolvimento financeiro: associação de duas empresas quando da procura de novos uma delas possui vulnerabilidade financeira associada a alguma vantagem.

mercados e/ou $\checkmark$ Desenvolvimento de capacidade: associação de duas empresas desenvolvimento de quando uma delas possui como ponto fraco a questão tecnológica, mas um tecnologias.

\subsubsection{Vantagem competitiva}

Porter (1989) afirma que a estratégia deve ser elaborada em função de uma análise interna e externa à empresa. Esta análise possibilita à empresa situar-se no papel que ocupa na indústria ou setor no qual atua, comparada aos demais concorrentes, e deve iniciar-se pela cadeia de valores, ou seja, a seqüência de atividades de 
relevância estratégica das empresas, com objetivo de compreender o comportamento dos custos e as fontes existentes de potenciais diferenciação.

A cadeia de valores de uma empresa é formada por atividades de valor que podem ser divididas em dois tipos gerais: atividades primárias e atividades de apoio. As atividades primárias são aquelas envolvidas na criação física do produto, na sua venda e transferência para o comprador e na assistência pós-venda, enquanto que as atividades de apoio sustentam o desenvolvimento das atividades primárias, fornecendo insumos, tecnologia e recursos humanos.

Oliveira (1991) destaca que o rumo mais adequado para a estratégia empresarial será aquele em que a empresa possa distinguir-se favoravelmente de suas concorrentes através de sua vantagem competitiva. Para este autor, é fundamental que a empresa saiba delinear a vantagem competitiva de forma a possibilitar a identificação dos produtos e os mercados nos quais está realmente capacitada a atuar.

De acordo com Bateman e Snell (1998), o ambiente externo de uma empresa exerce influência sobre a sua competitividade, e pode ser dividido em macroambiente e ambiente competitivo. O macroambiente é formado pelos agentes mais gerais do ambiente externo, quais sejam, o governo, o poder legislativo, os fomentadores e os fornecedores de tecnologia, os agentes da indústria da qual a empresa faz parte, a sociedade, os agentes que interferem na economia do país e, consequentemente, na atratividade da indústria.

O ambiente competitivo é formado por organizações específicas com as quais a organização interage. Porter (2004) estabelece que este ambiente é formado por concorrentes, novos entrantes, possíveis fornecedores de produtos substitutos, fornecedores e clientes. 


\subsubsection{Operacionalização do Planejamento Estratégico}

Conforme já verificado na introdução do tópico Planejamento Estratégico, o processo de administração estratégica é um processo de planejamento e decisão cujos principais componentes são: (1) estabelecimento da missão e visão; (2) análise ambiental; (3) avaliação interna; (4) formulação de estratégias; (5) implementação de estratégias; (6) controle estratégico e, conforme o esquema proposto, a formulação da estratégia é subsidiada pela análise ambiental e pela análise interna, que podem ser realizadas através da análise denominada SWOT (Strenghts, Weaknesses, Opportunities and Threats).

A análise ambiental deve iniciar-se através de um exame setorial que objetive compreender qual posição a empresa ocupa dentro de seu ambiente competitivo, e da análise do público interessado nos serviços ou produtos da empresa, que de alguma forma podem influenciar na missão, nos objetivos e nas estratégias da organização.

Com relação à análise interna, devem ser levantados os pontos fortes e os pontos fracos das principais áreas funcionais da empresa. A análise interna deve fornecer informações pertinentes ao panorama das habilidades e recursos da organização, bem como de seus níveis de desempenho gerais e funcionais. Para Bateman e Snell (1998), uma análise interna eficaz requer clara compreensão das competências essenciais da empresa, pois constituem as bases para o desenvolvimento de vantagem competitiva. Segundo estes mesmos autores, a discussão dos tópicos apresentados na Figura 2.7 é fundamental para análises (externa e interna) eficazes. 


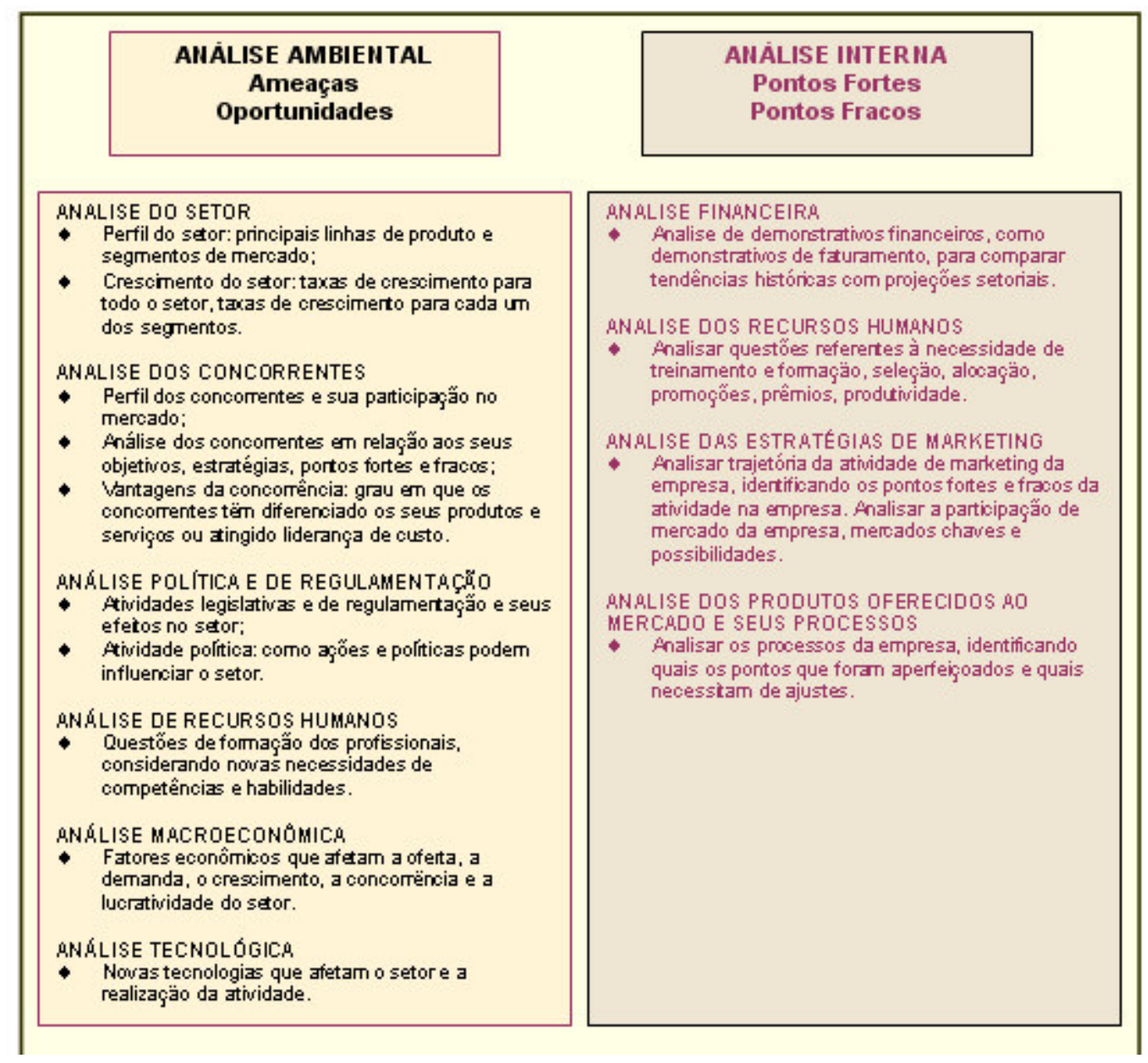

Figura 2.7 - Fatores relevantes para análise interna e externa, de acordo com Bateman e Snell (1998)

Segundo Liedtka (2000), o processo de planejamento estratégico pode ser caracterizado como um processo de aprendizado e de mudança contínua, onde é delineado um cenário atual do setor e a posição competitiva ocupada pela empresa. A partir desse processo, são estabelecidas estratégias para que seja alcançada uma posição ideal dentro deste mercado, que trazem a necessidade do desenvolvimento de competências.

Partindo dessa premissa, a autora desenvolve um modelo que denominou de "Modelo Produtivo", que possui como característica marcante o envolvimento do maior número possível de membros no processo de planejamento estratégico. Para tanto, é necessário o estabelecimento de toda uma rotina de organização para o processo.

O modelo proposto pela autora difere dos processos tradicionais, pois enfatiza o pensamento estratégico coletivo baseado no diálogo e na troca contínua de 
experiências, enquanto que os processos tradicionais focam a coordenação e o controle. O contexto da realização do planejamento estratégico, segundo a proposta da autora, está baseado no senso de urgência e em propostas organizacionais claras para todos os níveis da empresa.

Qualquer que seja a metodologia adotada para a realização do planejamento estratégico, recomenda-se o estabelecimento de objetivos mensuráveis para o seu acompanhamento, definidos dentro de um horizonte estratégico.

Thompson e Strickland (2001) estabelecem que o planejamento estratégico deve ser subsidiado pela quantificação dos objetivos estabelecidos, e tais objetivos devem ser, necessariamente, financeiros e estratégicos. Para os autores, os objetivos financeiros dizem respeito às ações que criaram valor para a empresa e estão relacionados ao acompanhamento das suas receitas, das despesas e do acompanhamento de retorno de investimentos. Já os objetivos estratégicos estão relacionados à posição de vendas e contratações da empresa, análise da posição de competidores no mercado, análise contínua de sua posição no mercado, e análises comparativas entre ofertas e serviços da empresa em relação aos seus competidores.

Complementado as características propostas por Thompson e Strickland (2001) sobre os objetivos estratégicos, Oliveira (1999) estabelece que eles devem:

$\checkmark$ sempre que possível, ser dispostos em escalas hierárquicas, demonstrando quais são secundários, quais são terciários, etc., e quais são determinados.

$\checkmark$ ser quantificáveis e alinhados com um sistema de controle e avaliação.

$\checkmark$ surgir de uma análise de oportunidades e ameaças ambientais, dos pontos fortes e fracos, e dos recursos disponíveis da empresa.

$\checkmark$ ser claros, documentados, comunicados e compreendidos para permitir maior amplitude de controle.

$\checkmark$ ser motivadores, a fim de facilitar o desenvolvimento das estratégias. 


\subsection{Gestão financeira}

De acordo com Atkinson, Banker, Kaplan, Young (2000), a gestão financeira de uma empresa tem como objetivo melhorar continuamente o processo de planejamento e controle, de forma a fornecer informações que orientem a tomada de decisão, a fim de que os objetivos estratégicos, táticos e operacionais sejam atingidos. Para tanto, deve ser subsidiada por um sistema que agregue informações de todas as áreas da empresa: produção, comercial, pessoas, tecnologia e estratégica.

Para Gitman (2004), o porte e a relevância da gestão financeira de uma empresa dependem do seu tamanho. Normalmente nas pequenas empresas essa função é desempenhada por contadores. À medida que a empresa cresce, essa função se transforma num departamento separado e ligado diretamente ao principal executivo da empresa.

As atividades de administração financeira e contabilidade em uma empresa se sobrepõem. A função primordial da contabilidade é produzir e divulgar dados para mensuração do desempenho da empresa, avaliando sua posição financeira, bem como organizar as contas para recolhimento de impostos.

O gestor financeiro dá mais ênfase aos fluxos de caixa, de forma a planejá-los e acompanhá-los com objetivo de que a empresa cumpra suas obrigações e adquira ativos necessários para atingir seus objetivos estratégicos.

Para os autores, a diferença básica entre controle financeiro e contabilidade tem a ver com a tomada de decisões. Os contadores focam seu trabalho na coleta e apresentação de dados financeiros, enquanto que os gestores financeiros avaliam as demonstrações contábeis, produzem dados adicionais e tomam decisões com base na avaliação dos retornos e riscos correspondentes.

De acordo com Paschoal Pinto (2007), o sistema contábil de uma empresa deve ser estruturado de modo que não entre em conflito com normas, legislações e princípios que regem a contabilidade, enquanto que o sistema financeiro deve estruturar-se de forma a gerar informações em conformidade com o modelo de decisão dos gestores, 
não tendo a obrigação de observar normas, legislação e princípios que regulam a contabilidade.

Independentemente do tamanho, de acordo com estes autores, o princípio econômico fundamental utilizado na gestão de custo é denominado de Análise Marginal, e consiste na regra de que uma decisão financeira deve ser tomada somente quando os benefícios adicionais superarem os custos adicionais, ou seja, praticamente todas as decisões financeiras reduzem-se a uma comparação de benefícios marginais a custos marginais.

\subsubsection{Organização e Demonstrações Financeiras}

De acordo com Paschoal Pinto (2007), as informações geradas acerca dos custos das empresas contemplam uma variedade de termos, e cada uma se refere a uma situação específica. Considerando que uma certa confusão quanto a sua utilização e abrangência ocorre com freqüência, a perfeita compreensão e correta aplicação das informações tornam-se fundamentais, facilitando, dessa forma, a comunicação e o seu melhor uso.

Segundo o autor, entendem-se por gastos os sacrifícios financeiros com que a empresa arca para atingir seus objetivos (obtenção de um produto ou realização de um serviço). O gasto implica em desembolso, seja no presente ou no futuro. Os custos são efetuados para obtenção de bens ou serviços. Em empresas prestadoras de serviços, os custos compreendem todos os insumos consumidos na realização do serviço.

As despesas compreendem os gastos realizados para geração da receita e administração da empresa, e os investimentos são os gastos realizados no presente que geram benefícios em períodos futuros.

Para a organização, tão importante quanto a compressão dos termos referentes a sua gestão financeira, é a categorização dos custos e despesas, que podem ser classificados como diretos, indiretos, fixos e variáveis. 
Paschoal Pinto (2007) define que os custos ou despesas diretas são aqueles que podem ser apropriados ao serviço prestado pela empresa ou produto fabricado de maneira objetiva, enquanto que os custos ou despesas indiretas são aquelas comuns a mais de um serviço prestado pela empresa ou produto fabricado. Nesse caso, a apropriação dos objetos de custeio ocorre por intermédio de algum artifício, comumente chamado de rateio.

Os custos ou despesas fixas e variáveis relacionam-se com o volume de atividades com as quais a empresa opera. Os custos ou despesas fixas são aquelas cujos consumos não se alteram de acordo com o aumento ou a redução do volume de atividades, enquanto que os custos ou despesas variáveis oscilam conforme o nível de atividade da empresa.

Além do conhecimento acerca dos termos básicos relacionados à gestão financeira, a devida organização do sistema contábil e financeiro de uma empresa, independentemente de sua sofisticação, passa pela definição dos seus objetivos. De acordo com Longenecker, Moore, Petty (2004) e Bodie, Merton (2002), o sistema contábil e financeiro de uma empresa deve, através dos seus demonstrativos, pelo menos:

produzir um quadro exato e completo dos resultados operacionais.

permitir comparações rápidas de dados correntes com resultados operacionais de anos anteriores e com metas orçamentárias.

$\checkmark$ fornecer demonstrativos para uso de seus administradores, bancos e credores potenciais.

$\checkmark$ facilitar o preenchimento imediato de relatórios e declarações de impostos para órgãos governamentais normativos e de arrecadação de impostos.

$\checkmark$ revelar fraudes, desvios e desperdícios, bem como possíveis erros de lançamentos.

$\checkmark$ fornecer informações para o planejamento financeiro da empresa. 
Paschoal Pinto (2007) ressalta que outro aspecto relevante para a eficácia do sistema de informações contábil e financeiro refere-se à definição do sistema de acumulação de custos da empresa, que está diretamente relacionado ao seu sistema de produção, e podem ser classificados como: sistema de acumulação por ordem de produção ou encomenda, e sistema de acumulação por processo.

O sistema de acumulação por ordem de produção ou encomenda é adequado para empresas que trabalham em função de encomendas e projetos específicos, ou seja, é necessário que seja firmado um contrato com um cliente para que uma ordem de serviço possa ser caracterizada. Nesse sistema, abre-se uma conta para cada novo contrato, na qual são apropriadas todas as suas despesas e custos. Por outro lado, o sistema de acumulação por processo é adequado às empresas que fabricam produtos padronizados em massa sob condições de processamento contínuo.

Em suma, o sistema financeiro deve permitir, através dos demonstrativos, o controle administrativo da empresa, fornecer modelos convenientes para o planejamento financeiro e subsidiar a tomada de decisões. Para tanto, ainda segundo Longenecker, Moore, Petty (2004), o sistema contábil financeiro deve ser alimentado, pelo menos, por registros de contas a receber; contas a pagar; estoque, folha de pagamento e caixa.

De acordo com Bodie e Merton (2002), grande parte das informações disponíveis àqueles que tomam decisões financeiras aparece na forma de demonstrações financeiras básicas, quais sejam, balanço patrimonial, resultado do exercício e fluxo de caixa, conforme ilustra a Tabela 2.14 Para os autores, embora as demonstrações financeiras raramente forneçam informações suficientes para formar julgamentos conclusivos à respeito do desempenho da companhia, podem fornecer indícios importantes sobre aspectos das operações de uma empresa que devem ser reexaminados. 


\begin{tabular}{|c|c|c|}
\hline \multirow{3}{*}{ 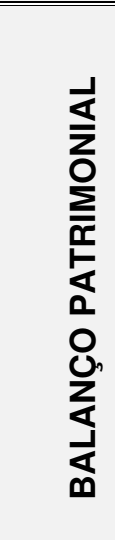 } & Objetivos & $\begin{array}{l}\text { Mostrar os ativos da empresa, num determinado momento. As } \\
\text { diferenças entre os ativos e passivos correspondem ao patrimônio } \\
\text { liquido da empresa. }\end{array}$ \\
\hline & $\begin{array}{l}\text { Definições } \\
\text { Importantes }\end{array}$ & $\begin{array}{l}\text { Ativos: o que é de propriedade da empresa (exemplo: } \\
\text { equipamentos, software, mobiliário, imóveis, ações). } \\
\text { Passivos: o que é da empresa num determinado momento } \\
\text { (exemplo: títulos de contas a pagar e empréstimos). }\end{array}$ \\
\hline & Benefícios & 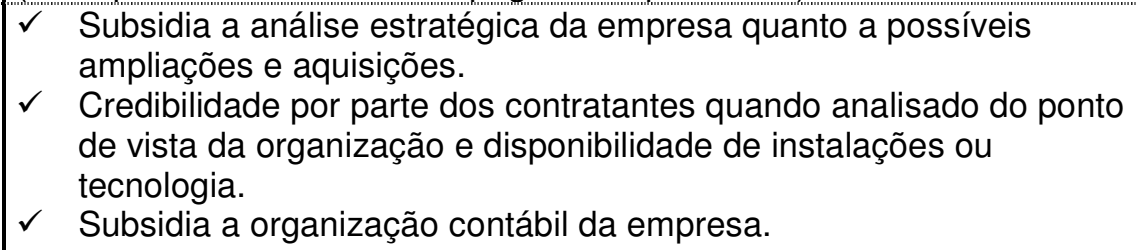 \\
\hline \multirow{3}{*}{ 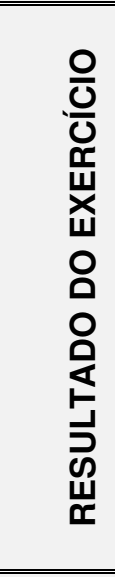 } & Objetivos & $\begin{array}{l}\text { Resume a rentabilidade da empresa durante um determinado } \\
\text { período. Nesse caso, o lucro ou resultados significam a diferença entre } \\
\text { as receitas e despesas. }\end{array}$ \\
\hline & $\begin{array}{l}\text { Definições } \\
\text { Importantes }\end{array}$ & $\begin{array}{l}\text { Margem Bruta: diferença entre receitas e o custo de um } \\
\text { produto ou serviço. } \\
\text { Lucro Operacional: diferença entre margem bruta e } \\
\text { despesas. } \\
\text { Lucro Tributável: receita sujeita ao imposto de renda. }\end{array}$ \\
\hline & Benefícios & 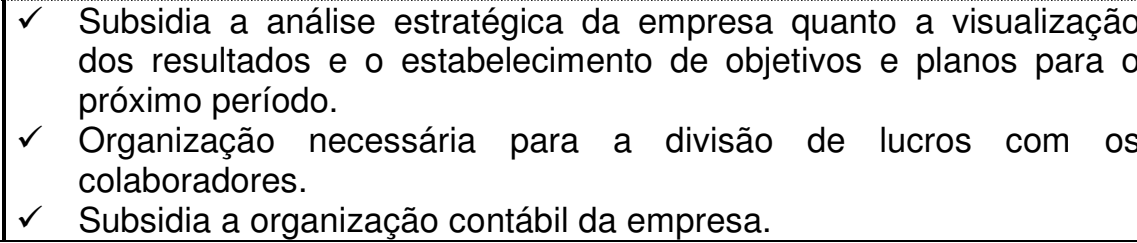 \\
\hline \multirow{3}{*}{ 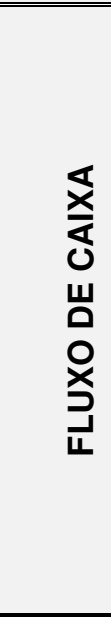 } & Objetivos & $\begin{array}{l}\text { Demonstra todo o dinheiro que entra a sai de uma empresa } \\
\text { num determinado período. }\end{array}$ \\
\hline & $\begin{array}{l}\text { Definições } \\
\text { Importantes }\end{array}$ & $\begin{array}{l}\text { Capital de Giro: soma dos ativos circulantes da empresa } \\
\text { (dinheiro, contas a receber e inventários) com passivos circulantes } \\
\text { (contas a pagar e empréstimos curto prazo). } \\
\text { Fluxo de Capital de Giro: fluxo de recursos através das } \\
\text { contas de capital de giro da empresa. }\end{array}$ \\
\hline & Benefícios & 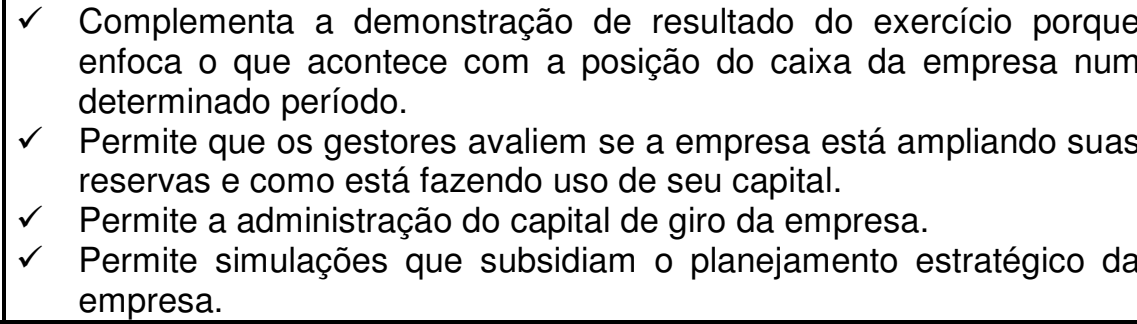 \\
\hline
\end{tabular}

Tão importante quanto a perfeita elaboração dos demonstrativos financeiros é a sua correta interpretação, pois, segundo Gitman (2002), a análise das demonstrações financeiras de uma empresa é o ponto de partida para melhor compreendê-la. Para o autor, os possíveis credores, investidores e partes interessadas em geral de uma empresa, ao analisarem os demonstrativos financeiros, procuram informações que os assegurem de que a empresa encontra-se em situação saudável e que continuará bem sucedida ao longo do tempo. O que se percebe através das análises 
de diversas empresas é que a lucratividade isolada não é sinônimo de saúde financeira.

De acordo com o autor, a análise dos demonstrativos financeiros de uma empresa através de índices setoriais, ao invés de valores monetários absolutos, é uma forma eficaz de comparação da situação da empresa em relação a todo o setor, e até mesmo em relação a concorrentes que, obrigatoriamente, tenham que publicar seus balanços e demonstrações.

A utilização de índices setoriais na interpretação dos demonstrativos financeiros é benéfica para a análise denominada de série-temporal, que fornece informações sobre o desempenho da empresa ao longo do tempo, se está progredindo ou regredindo.

Gitman (2002) alerta que a análise realizada a partir de apenas um índice pode não fornecer informações suficientes para a avaliação do desempenho global de uma empresa. As demonstrações financeiras comparadas devem ser do mesmo mês de encerramento, caso contrário, os efeitos de sazonalidade, dependendo do setor, podem levar conclusões equivocadas.

\subsubsection{Processo de Planejamento Financeiro}

A elaboração e posterior análise dos demonstrativos financeiros de uma empresa devem subsidiar o seu planejamento financeiro.

Segundo Bodie e Merton (2002), o planejamento financeiro de uma empresa é um processo dinâmico que percorre um ciclo de confecção de planos, sua implementação e revisão à luz dos resultados reais. O ponto de partida no desenvolvimento de um plano financeiro é o plano estratégico da empresa, que o orienta ao estabelecer diretrizes gerais de desenvolvimento e metas de crescimento, ou seja, que linhas de negócio a empresa deseja expandir e como o fará.

Para Gitman (2002), o planejamento financeiro de uma empresa deve ser estruturado através de planos financeiros à longo prazo e planos financeiros à curto 
prazo. Tais planos devem ser subsidiados pela previsão de vendas e negócios da empresa, bem como orçamentos de caixa.

Ainda de acordo com este autor, os planos financeiros à longo prazo são ações planejadas vinculadas diretamente às estratégias da empresa, e integradas ao seu plano de marketing. O horizonte deste planejamento depende do nível de incertezas e possíveis sazonalidades às quais o setor no qual a empresa atua pode estar sujeito, bem como o tipo de produto ou serviço que fornece.

Os planos financeiros de curto prazo são ações planejadas para um período menor, e os principais insumos para sua elaboração incluem a previsão de vendas e orçamentos de caixa.

Segundo o mesmo autor, orçamento de caixa é o demonstrativo de fluxo das entradas e saídas das empresa, utilizado para a descrição de todas as despesas da empresa a curto prazo e receitas. Esse demonstrativo possibilita uma visão clara do momento de ocorrência dos fluxos esperados de entrada e saídas de recursos ao longo de um período.

A previsão de vendas define-se como um prognóstico das vendas da empresa projetadas para um determinado período. Com base nessa previsão, é possível estimar os fluxos de caixa mensais, resultantes da projeção dos recebimentos de vendas.

Através do orçamento de caixa é possível analisar a situação real da empresa. Quando inseridas as previsões de vendas, é possível a realização de simulações e análises do fluxo de caixa da empresa, de forma a retroalimentar os processos de marketing e os processos operacionais da empresa.

\subsection{Sistema de informação e gestão do conhecimento}

De acordo com Turban; MacLean; Wetherbe (2004), o sistema de informação coleta, processa, armazena, analisa e dissemina informações com um determinado objetivo dentro de um contexto. Conforme a Figura 2.8, o sistema de informação, como 
qualquer outro sistema, inclui inputs (dados, instruções) e outputs (relatórios, cálculos). Este sistema opera dentro de um ambiente, não necessariamente computadorizado, e processa os inputs, que são enviados para o usuário ou para outros sistemas.

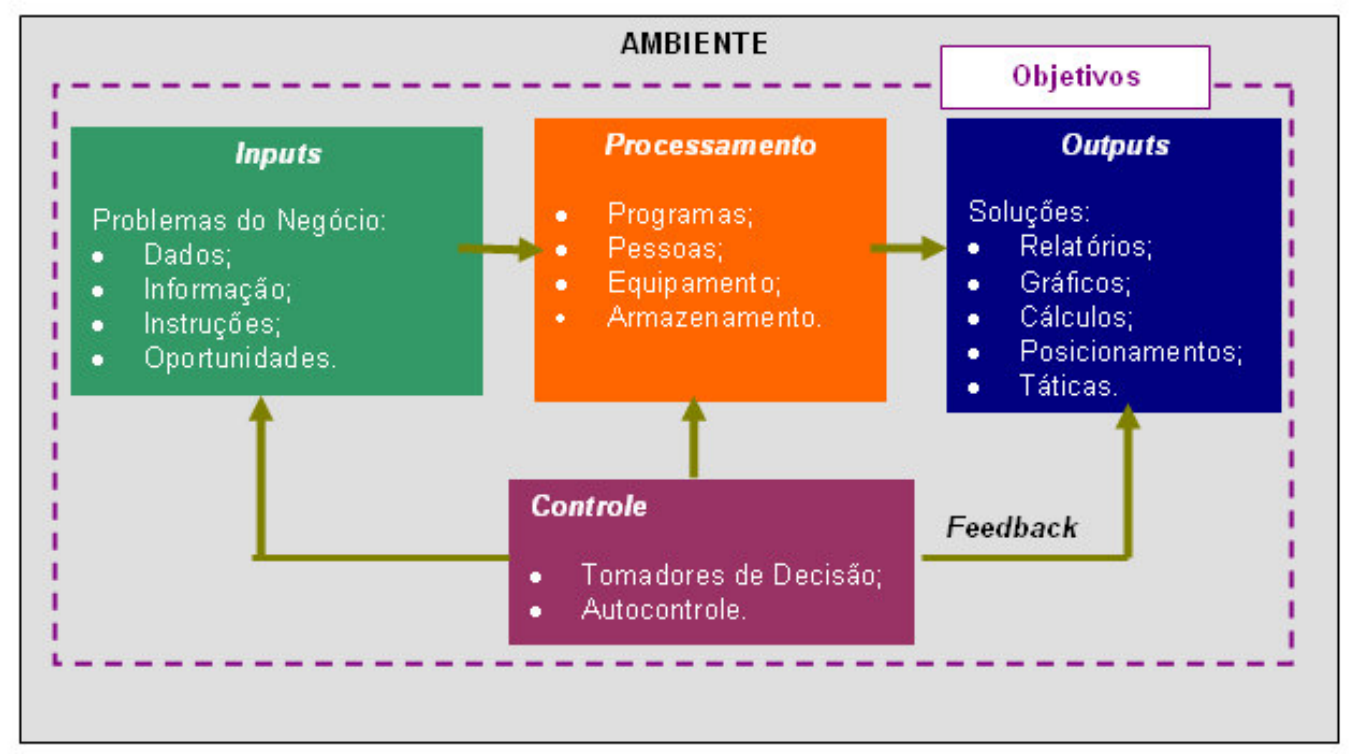

Figura 2.8 - Visão esquemática de um sistema de informação, adaptado de Turban; McLean; Wetherbe (2004)

Para o perfeito entendimento do sistema de informações operando com objetivos pré-definidos, é necessário compreender que as informações surgem a partir de dados organizados e processados de forma a proporcionar valor às atividades da empresa, permitindo aos gestores a tomada de decisões e a realização de seu trabalho. O sistema de informações, se bem projetado, deve permitir aos seus usuários a geração de conhecimento para a organização.

Os sistemas de informações podem ser classificados, em princípio, como formais e informais. Os sistemas de informação formais incluem procedimentos pré-definidos, entradas e saídas padronizadas e definições fixas. Quanto aos informais, estes assumem diversas formas, que vão desde uma "rede de comunicação informal" numa empresa, até um grupo de amigos que troca correspondência eletronicamente. 
Turban; MacLean; Wetherbe (2004) classificam ainda os sistemas de informação por níveis organizacionais, por área funcional e tipo de suporte proporcionado, conforme demonstra a Tabela 2.15 .

\begin{tabular}{|c|c|c|}
\hline$\overline{\text { bela } 2}$ & & \\
\hline $\begin{array}{l}\text { Nível } \\
\text { Organizacional: }\end{array}$ & $\begin{array}{ll}\text { Sistema } & \text { de } \\
\text { informações } & \text { por } \\
\text { departamento } & \end{array}$ & $\begin{array}{l}\text { É desenhado para realizar uma função específica } \\
\text { diretamente para o usuário. Alguns aplicativos podem } \\
\text { ser completamente independentes entre si, enquanto } \\
\text { outros são inter-relacionados. }\end{array}$ \\
\hline $\begin{array}{l}\text { sistemas } \\
\text { tipicamente } \\
\text { afinados com a }\end{array}$ & $\begin{array}{|ll|}\text { Sistemas } & \text { de } \\
\text { informações } & \\
\text { empresariais } & \\
\end{array}$ & $\begin{array}{l}\text { Conjunto de aplicativos departamentais: quando } \\
\text { combinado com outros aplicativos funcionais, forma o } \\
\text { sistema de informaç̃es empresariais. }\end{array}$ \\
\hline organizacional & \begin{tabular}{|l} 
Sistema \\
informações de \\
interorganizacionais
\end{tabular} & $\begin{array}{l}\text { São sistemas comuns de informação entre empresas } \\
\text { parceiras. São fundamentais no comércio eletrônico e } \\
\text { no suporte à cadeia de suprimentos. }\end{array}$ \\
\hline & $\begin{array}{|ll|}\text { Sistema } & \text { de } \\
\text { processamento } & \text { de } \\
\text { transação (SIT) } & \\
\end{array}$ & $\begin{array}{l}\text { Dá suporte às atividades repetitivas vitais e ao pessoal } \\
\text { administrativo. }\end{array}$ \\
\hline & \begin{tabular}{|lr} 
Sistema & de \\
informação & gerencial \\
(SIG) &
\end{tabular} & $\begin{array}{l}\text { Dá suporte às atividades funcionais e aos } \\
\text { administradores. }\end{array}$ \\
\hline & \begin{tabular}{|lr} 
Sistema & de \\
Administração & do \\
Conhecimento (KMS)
\end{tabular} & $\begin{array}{l}\text { Dá suporte a todos os tipos de necessidades de } \\
\text { informações ao pessoal administrativo. }\end{array}$ \\
\hline Tipo de suporte & $\begin{array}{|ll|}\text { Sistema } & \text { de } \\
\text { automação } & \text { de } \\
\text { escritório (SAE) } & \\
\end{array}$ & $\begin{array}{l}\text { Dá suporte ao pessoal administrativo, como, por } \\
\text { exemplo, sistemas de comunicação. }\end{array}$ \\
\hline pr & $\begin{array}{l}\text { Sistema de apoio à } \\
\text { decisão (SAD) }\end{array}$ & $\begin{array}{l}\text { Dá suporte à tomada de decisões pelos } \\
\text { administradores e analistas. }\end{array}$ \\
\hline & $\begin{array}{|ll|}\text { Sistema } & \text { de } \\
\text { informação } & \\
\text { empresarial (EIS) } & \\
\end{array}$ & $\begin{array}{l}\text { Dá suporte à todos os administradores de uma } \\
\text { empresa. }\end{array}$ \\
\hline & $\begin{array}{l}\text { Sistema de apoio aos } \\
\text { grupos (GSS) }\end{array}$ & Dá suporte ao pessoal, trabalhando em grupos. \\
\hline & $\begin{array}{l}\text { Sistema de suporte } \\
\text { inteligente }\end{array}$ & $\begin{array}{l}\text { Dá suporte principalmente aos profissionais do } \\
\text { conhecimento, mas também apoia outros grupos de } \\
\text { funcionários, sendo os sistemas especialistas a sua } \\
\text { principal tecnologia. }\end{array}$ \\
\hline
\end{tabular}

Para Oliveira (1998), os sistemas de informações gerenciais devem levar em consideração a quantidade e a qualidade das informações geradas. Para o autor, alguns cuidados devem ser tomados com relação a esses fatores:

- As informações ficam dispersas dentro da empresa, o que exige grande esforço para localizá-las.

- As informações importantes são retidas com exclusividade. 
- As informações importantes geralmente chegam tarde.

- As informações, muitas vezes, não são confiáveis.

\subsubsection{O papel da informação nas empresas}

Drucker (1995) observa que, atualmente, poucos entendem a informação; sabem como obter dados, mas precisam aprender a usá-los, pois uma base de dados, por maior que seja, não é informação, e para que se transforme em informação precisa ser organizada para uma determinada tarefa, dirigida para desempenho específico aplicada a uma decisão. Para o autor, as empresas, assim como seus colaboradores, precisam conhecer a informação e aprender a perguntar: De que informações necessitamos na empresa? Quando necessitamos dela? De que forma? Onde obtê-las?

De acordo com Evgeniou e Cartwrighit (2005), a empresa inteligente - do ponto de vista da informação, possui habilidade para buscar, organizar, analisar e fazer uso de informações para a tomada de decisões. Os autores ressaltam que esta busca deve ser constante para as organizações qualquer que seja sua área de atuação, pois a detenção e o controle da informação são fundamentais para o sucesso de atividades que vão desde o sequenciamento do genoma humano até a previsão e rastreamento de atentados terroristas.

Evgeniou e Cartwrighit (2005) observam que existem três fatores que podem ser considerados como barreiras para o desenvolvimento desta habilidade:

- Barreiras comportamentais: ocorrem principalmente em função do comportamento dos gestores e tomadores de decisão.

- Barreiras relacionadas ao processo: ocorrem em função das características do processo, relacionadas principalmente à insucessos na definição do problema "sistema de informação". 
- Barreiras organizacionais: ocorrem em função de mudanças repentinas que podem acontecer na organização.

Segundo os autores, os problemas organizacionais decorrentes do desenvolvimento de projetos relacionados ao sistema de informações podem ser minimizados com o alto grau de envolvimento das equipes e com a transparência em todo o processo.

\subsubsection{Sistema de retroalimentação da informação e gestão do conhecimento}

Segundo Drucker (1995), ao longo da história do ocidente, a cada poucos séculos ocorrem transformações agudas que fazem com que toda a sociedade se rearranje em relação a sua visão do mundo, aos seus valores básicos, às suas estruturas sociais e políticas, suas artes, suas instituições básicas. Para o autor, a época em que vivemos atualmente é um desses períodos de transformação, e não está limitada à sociedade ocidental e sua história, pois atualmente não existe mais uma história "ocidental" ou uma "civilização ocidental", mas apenas a história do mundo e a civilização mundial.

O processo pelo qual estamos passando nos transforma na sociedade do conhecimento, na qual o principal recurso para os indivíduos e para a economia em geral é o conhecimento. Drucker (1995) ainda ressalta que, em função dessa transformação, a sociedade precisa estar organizada para a inovação e para o abandono de tudo aquilo que é estabelecido, costumeiro, conhecido e confortável, ou seja, a sociedade precisa estar preparada para transformações constantes e, dentro desse contexto, a função das empresas é colocar todo seu potencial (utilizando-se de ferramentas, produtos e processos) na busca do próprio conhecimento que, por natureza, muda rapidamente.

De acordo com Turban; MacLean; Wetherbe (2004), no contexto de sistema de informações, conhecimento é diferente de informações e dados. A Figura 2.9 ilustra que os dados são uma coleção de fatos, parâmetros e estatísticas; as informações são dados organizados ou processados, precisos e fornecidos no momento oportuno; enquanto que o conhecimento é a informação que possui contexto, é 
relevante e acionável. Possuir conhecimento implica diretamente na resolução de problemas; possuir informação não detém a mesma conotação.

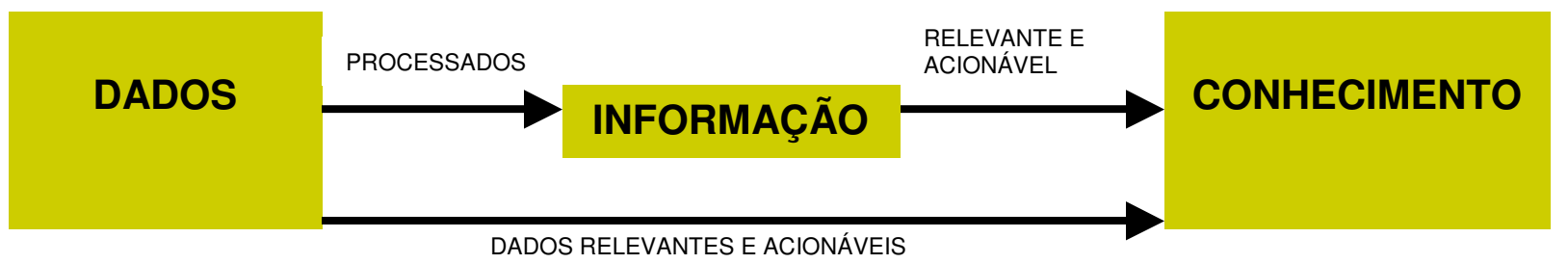

Figura 2.9 - Processamento de dados em informação e em conhecimento, de acordo com Turban; McLean; Wetherbe (2004)

Os processos de disseminação do conhecimento normalmente iniciam-se associados às pessoas, e se esse processo não ocorrer de forma planejada e sistematizada, as pessoas, ao saírem da empresa, levam consigo este conhecimento. Segundo Turban; MacLean; Wetherbe (2004), uma meta vital relacionada à gestão do conhecimento é segurar esse valioso" know-how", pois o conhecimento está associado a retornos crescentes para empresa e a tendência é que, ao ser utilizado, o seu valor aumente. Dessa forma, conhecimento é uma informação em ação; portanto, é necessária a contínua atualização da base de conhecimento da empresa para torná-la competitiva. O valor do conhecimento e do seu compartilhamento é inestimável, pois há um grande número de aspectos intangíveis associados à sua aquisição.

As modernas tecnologias de colaboração podem auxiliar as iniciativas de gestão do conhecimento; no entanto, Turban; MacLean; Wetherbe (2004) observam que o aprendizado das empresas depende menos da tecnologia e mais das questões pessoais e organizacionais de predisposição de aprendizado.

Para os autores, a expressão "empresa que aprende" está associada à gestão do conhecimento e baseia-se nos conceitos de aprendizado organizacional e memória organizacional. A expressão refere-se à capacidade de uma empresa aprender com suas experiências passadas. 
Diversos são os autores que argumentam sobre a importância e as vantagens da utilização das ferramentas de marketing nas empresas. No entanto, verifica-se resistência, por parte das pequenas empresas, na utilização das ferramentas e conhecimentos desenvolvidos nessa área de conhecimento. De acordo com Sarquis (2003), isso se deve principalmente a limitação gerencial por parte dos microempresários, bem como a incertezas relativas à eficácia e validade do marketing e falta de conhecimento sobre o assunto, o que leva a visões equivocadas sobre as ferramentas e suas utilizações, e, finalmente, a limitações de recursos financeiros para investimentos na área.

A função do Marketing dentro das empresas é, essencialmente, lidar com os clientes. Segundo Kotler e Armstrong (2003), entender, criar, comunicar e proporcionar ao cliente valor e satisfação, constituem a essência do pensamento e da prática do marketing moderno. Nesse sentido, os autores definem Marketing como o processo administrativo e social pelo qual indivíduos e grupos obtêm o que necessitam e desejam, por meio da criação, oferta e troca de produtos com os outros.

Ainda de acordo com Kotler e Armstrong (2003), as empresas bem-sucedidas são aquelas que definem o mercado-alvo, identificam as necessidades e expectativas dos clientes, procuram satisfazer as necessidades desses mesmos clientes de forma rápida e eficaz, dedicam atenção à qualidade dos produtos e serviços, e estão decididamente orientadas para os clientes.

Conforme Sarquis (2003), o estudo sobre a prática de marketing na pequena empresa leva a uma questão inicial: comparada com as médias e grandes empresas, a pequena empresa está ou não em desvantagem quanto ás possibilidades de praticar o marketing?

O autor argumenta que boa parte dos profissionais e executivos de marketing acreditam que as pequenas empresas, quando comparadas com as empresas de médio e grande porte, possuem menores possibilidades de utilizar instrumentos de 
marketing; entretanto, entendem que a pequena empresa dispõe de fatores inerentes às suas próprias características que lhe servem de vantagem nesse sentido.

Tais fatores, via de regra de natureza operacional, são facilidades de aproximação com o seu cliente, que possibilita conhecer melhor os seus desejos, necessidades e expectativas; maior rapidez na tomada de decisões; maior versatilidade e flexibilidade para efetuar movimentações estratégicas no mercado; possibilidade de o empresário controlar e dirigir pessoalmente as operações e os contatos com os clientes; maior capacidade de identificação e aproveitamento das oportunidades de mercado; maior uso da capacidade criativa empresarial e facilidade de prestar um atendimento veloz e personalizado; de particularizar a produção por tipo de cliente; e de "encantar" o cliente pela qualidade nos serviços de apoio.

Em síntese, a prática viável do marketing nas pequenas empresas deve ser estabelecida a partir da proximidade com o cliente, agilidade e flexibilidade na tomada de decisões, bem como da facilidade para adaptar-se às exigências do mercado. Nesse sentido, as pequenas empresas devem estabelecer suas estratégias e ações de marketing fazendo uso das vantagens que possui, e não utilizar as suas limitações como argumento para não desenvolvê-las.

\subsubsection{Caracterização do Mercado}

O conhecimento e a perfeita caracterização do mercado consumidor de uma empresa é outro aspecto a ser explorado para o perfeito estabelecimento da estratégia de marketing.

Os projetos de edifícios não são produtos de massa, vendidos em grande escala para uma parcela significativa da sociedade. Normalmente, o contratante do serviço projeto é a empresa que define o produto edifício, o fabrica e disponibiliza para o consumidor final. 
Sendo assim, o mercado das empresas de projeto é definido por Kotler e Armstrong (2003) como empresarial, ou seja, organizações que compram bens e serviços que são vendidos, alugados ou fornecidos a terceiros, sendo que o processo de compra resultante dessa relação denomina-se compra organizacional. Nesse processo, as empresas que vendem para outras organizações devem fazer o máximo para entender o mercado empresarial que atende o comportamento do comprador organizacional.

De acordo com os autores, o mercado empresarial é parecido com o mercado consumidor. Entretanto, as diferenças aparecem quando analisadas a estrutura e a demanda do mercado, a natureza da unidade de compra e o processo de decisão.

Quanto a estrutura e demanda, o mercado empresarial possui menos compradores; no entanto, se comparado ao mercado consumidor, o poder de aquisição e negociação dos compradores é bem maior. Outra diferença é que a demanda do mercado empresarial é derivada da demanda do consumidor final e, em função desse aspecto, pode oscilar em maior proporção e mais rapidamente.

Os parâmetros adotados para embasar a decisão de compra são mais complexos, o processo de compra é, normalmente, profissional e, portanto, mais formal; os compradores e vendedores trabalham de forma mais direta e, como consequência, os relacionamentos estabelecidos podem ser mais duradouros.

Assim como no marketing tradicional, os profissionais que atuam no marketing empresarial precisam conhecer os envolvidos nos processos de compra organizacional, o seu comportamento e como responderão aos seus estímulos.

Na Tabela 2.16, estão contemplados os aspectos referentes ao comportamento do comprador organizacional no que se refere aos principais tipos de compra organizacional, ao perfil dos participantes nesse processo e fatores que influenciam o comprador. 


\begin{tabular}{|c|c|c|}
\hline \multirow{3}{*}{ 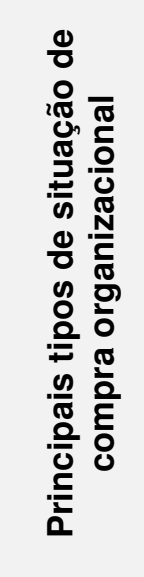 } & Recompra Simples & $\begin{array}{l}\text { O comprador repete a compra sem nenhuma modificação } \\
\text { baseado em referências quanto à qualidade de compras } \\
\text { anteriores. }\end{array}$ \\
\hline & $\begin{array}{l}\text { Recompra } \\
\text { Modificada }\end{array}$ & $\begin{array}{l}\text { O comprador decide modificar as especificações do } \\
\text { produto, os preços, as condições ou os fornecedores e, } \\
\text { normalmente, envolve mais participantes do que na } \\
\text { recompra simples, por exemplo. }\end{array}$ \\
\hline & Nova Compra & $\begin{array}{l}\text { Trata-se da compra de um produto ou serviço pela } \\
\text { primeira vez; a empresa se defronta com a situação de } \\
\text { uma nova compra. Nesses casos, quanto maior o custo ou } \\
\text { o risco, maior será o número de participantes na decisão e } \\
\text { maiores serão os esforços para coletar as diversas } \\
\text { informações referentes à compra. }\end{array}$ \\
\hline \multirow{5}{*}{ 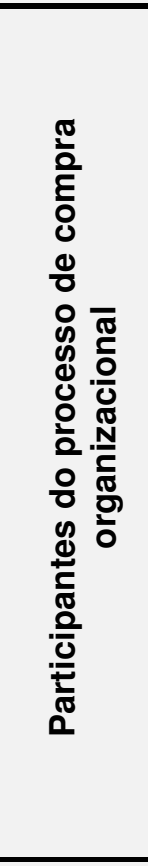 } & Usuários & $\begin{array}{l}\text { São os membros da organização que se utilizarão do } \\
\text { produto ou serviço. Na maior parte dos casos, dão início à } \\
\text { proposta de compra e ajudam a definir as especificações } \\
\text { do produto. }\end{array}$ \\
\hline & Influenciadores & $\begin{array}{l}\text { Geralmente ajudam a definir as especificaçōes para a } \\
\text { avaliação das alternativas. Os profissionais da área } \\
\text { técnica são influenciadores particularmente importantes } \\
\text { no processo de compra organizacional. }\end{array}$ \\
\hline & Compradores & $\begin{array}{l}\text { Possuem autoridade formal para selecionar o fornecedor } \\
\text { ditar as condições de compra. Os compradores podem } \\
\text { ajudar na formulação das especificações do produto, mas } \\
\text { seu principal papel é o de selecionar os fornecedores e } \\
\text { negociar com eles. Em compras mais complexas, podem } \\
\text { solicitar a participação da alta gerência nas negociações. }\end{array}$ \\
\hline & ecisores & $\begin{array}{l}\text { Têm poder formal ou informal para selecionar ou aprovar } \\
\text { os fornecedores finais. }\end{array}$ \\
\hline & Filtr & $\begin{array}{l}\text { Controlam o fluxo de informações no processo de compra. } \\
\text { Normalmente, esses agentes impedem que os } \\
\text { vendedores tenham acesso, por exemplo, aos usuários } \\
\text { e/ou decisores. }\end{array}$ \\
\hline \multirow{4}{*}{ 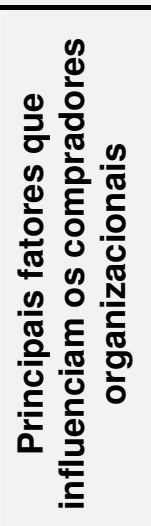 } & Fatores Ambientais & $\begin{array}{l}\text { Conjuntura econômica; Condições de fornecimento; } \\
\text { Mudanças tecnológicas; Desenvolvimento político e de } \\
\text { leis; Desenvolvimento da concorrência; Cultura e } \\
\text { costumes. }\end{array}$ \\
\hline & $\begin{array}{r}\text { Fator } \\
\text { Organiza }\end{array}$ & $\begin{array}{l}\text { Objetivos; } \quad \text { Políticas; } \\
\text { organizacional; Sistemas. }\end{array}$ \\
\hline & $\begin{array}{c}\text { Fatores } \\
\text { Interpessoais }\end{array}$ & Autoridade; Status; Empatia; Poder de Persuasão. \\
\hline & Fatores Individuais & $\begin{array}{l}\text { Idade; Nível de instrução; Cargo; Personalidade; Atitude } \\
\text { em relação ao risco. }\end{array}$ \\
\hline
\end{tabular}


Conforme a Tabela 2.16, existem três tipos principais de situação de compra. Num extremo está a recompra simples, que trata de decisões rotineiras numa empresa. No outro extremo, está a nova compra, que normalmente está vinculada ao envolvimento de um número maior de profissionais e pode exigir pesquisas mais detalhadas. No meio está a recompra modificada, que requer alguma pesquisa e pode envolver mais profissionais do que a recompra simples, por exemplo. Outro aspecto que deve ser levado em consideração no estabelecimento das estratégias de marketing são os participantes que conduzem o processo de compra organizacional e tomam as decisões inerentes à aquisição.

Tão importante para o estabelecimento de estratégias de marketing quanto conhecer os possíveis tipos de compra do mercado organizacional no qual atua a empresa e o perfil dos envolvidos no processo de aquisição, é conhecer quais fatores podem influenciar positiva ou negativamente na decisão de compra empresarial. Segundo Kotler e Armstrong (2003), tais fatores podem ser externos à empresa, tal como conjuntura, até questões pessoais relacionadas ao perfil de quem participa do processo e decide a compra.

\subsubsection{Estratégia de Produto}

De acordo com Kotler e Armstrong (2003), produto é definido como algo que pode ser oferecido a um mercado para apreciação, aquisição, uso ou consumo, e para satisfazer um desejo ou uma necessidade. A definição de produto proposta pelos autores inclui bens físicos, serviços, eventos, pessoas, lugares, organizações, idéias, ou um misto de todas essas entidades.

O produto "projetos de edifícios" pode ser entendido como um processo composto por uma série de decisões e ações, tomadas em função de um conjunto de necessidades pré-estabelecidas pelo cliente ou contratante, tendo como resultado um conjunto de especificações para a construção da edificação, produto esse tangível e facilmente avaliado quanto a qualidade final e desempenho. Por outro lado, o processo de projeto ocorre basicamente em função da relação e troca de 
informações entre contratante, contratado e demais componentes da equipe multidisciplinar de projeto, ou seja, trata-se de um processo com alto grau de intangibilidade, perecibilidade, variabilidade e inseparabilidade, caracterizando-o, dessa forma, como um serviço.

De acordo com Lovelock e Wright (1999), para que a empresa possa se estabelecer com eficácia no mercado em que atua, é necessário que seus serviços sejam delineados a partir da necessidades reais de seus clientes. Para tanto, segundo os autores, os seguintes passos devem ser seguidos: definir os atributos mais importantes dos serviços que devem ir ao encontro das necessidades reais dos clientes; em função do conhecimento dos seus atributos, investigar em quais aspectos os concorrentes são vulneráveis ou possuem excelência; ser consciente das reais e potenciais capacidades da empresa para atendimento adequado do serviço proposto; e, finalmente, desenvolver uma estratégia eficaz de introdução do serviço no mercado.

Levando em consideração a sua complexidade e números de variáveis envolvidas na sua execução, os autores sugerem como ferramenta para a visualização de um serviço o método denominado "Blueprint". Trata-se de um fluxo de atividades inerentes ao serviço, com o objetivo principal de demonstrar cada atividade necessária para a sua realização, desde a contratação até a finalização, bem como os recursos envolvidos e interações com o cliente em todas as suas fases.

Para que o método seja eficaz, é necessário que haja cuidado com relação aos seguintes aspetos:

- "Blueprint" deve ser representado como um diagrama, de forma que fiquem visíveis a sequência de atividades empreendidas para realização do serviço, o tempo despendido e os recursos utilizados em cada uma das etapas.

- Devem ser identificados os dados de entrada, pontos críticos e processos relacionados.

- Devem ser identificados no fluxo os critérios para perfeito atendimento do cliente quanto a qualidade e desempenho. 
Kotler e Armstrong (2003) salientam que uma estratégia eficaz de marketing para introdução de um serviço no mercado deve levar em consideração, além dos requisitos dos clientes, um trabalho de marketing interno, de forma a envolver $\mathrm{e}$ motivar os colaboradores, desenvolvendo continuamente as capacidades de atendimento dos serviços que prestam.

\subsubsection{Estratégia de Marketing, comunicação e venda pessoal}

De acordo com Kotler e Armstrong (2003), o mix de comunicação de marketing de uma empresa consiste na composição de instrumentos de comunicação, tais como propaganda, venda pessoal, promoções de venda, relações públicas e marketing direto.

A propaganda é qualquer forma paga de apresentação e promoção não pessoal de idéias, bens ou serviços, por um patrocinador identificado. A venda pessoal consiste na apresentação feita pela equipe comercial da empresa com o propósito de efetuar vendas e desenvolver relacionamentos com os clientes. A promoção de vendas está relacionada aos incentivos de curto prazo, com o objetivo de estimular a compra ou a venda de um produto ou serviço. As relações públicas consistem no desenvolvimento de boas relações com os diversos públicos da empresa, com objetivo de efetuar a construção de uma boa imagem. Finalizando, o marketing direto está relacionado ao contato próximo com clientes cuidadosamente classificados, com o objetivo de obter resposta direta de vendas, fazendo uso de ferramentas adequadas ao porte da empresa e dos serviços ofertados, de forma a construir relacionamentos duradouros.

Verifica-se que a eficácia do sistema de comunicação escolhido pela empresa com o objetivo de operacionalizar sua estratégia de marketing depende, em primeira instância, do tipo de produto ofertado, do objetivo da comunicação e, principalmente, do amplo conhecimento das características do público-alvo a ser atingido.

Para o caso de uma empresa de projeto, observa-se que o canal de comunicação mais adequado para a operacionalização da estratégia de vendas é o marketing direto e a venda pessoal, pois o serviço oferecido por essas empresas não é vendido em grande escala, e consiste basicamente na proposição de soluções técnicas a serem transformadas em especificações do produto edifício e o número 
de clientes é bastante reduzido, se comparado a empresas de serviços de outros segmentos, como hotelaria e educação, por exemplo.

Nesse sentido, é fundamental para a eficácia do marketing direto o tratamento adequado das informações relacionadas aos clientes e ao mercado. De acordo com Sarquis (2003), não há estratégia de marketing eficiente com precariedade de informações. Para o autor, é básico que a pequena empresa disponha de um conjunto de dados e informações relacionados ao perfil, necessidades e grau de satisfação de seus clientes; às ações dos concorrentes; à evolução do mercado; ao comportamento das variáveis ambientais que influenciam a empresa; às capacitações da empresa; à sua participação no mercado por produto; à participação de cada um dos produtos no faturamento da empresa; e à participação de cada um dos clientes no faturamento da empresa.

\subsubsection{Planejamento de Marketing}

De acordo com Sarquis (2003), a utilização dos planejamentos de marketing é uma prática recomendada; no entanto, as pequenas empresas não o fazem. O plano de marketing deve tratar basicamente da operacionalização da estratégia de marketing da empresa, estabelecida em função de um portfólio de produtos, de informações referentes ao ambiente onde a empresa está inserida, dos clientes atuais e potenciais e da estratégia de comunicação.

Para o autor, a eficácia do plano de marketing depende do envolvimento do principal executivo da empresa em todas as suas etapas, pois é esse o profissional responsável pelas decisões técnicas e estratégicas. O planejamento de marketing deve estar adequado à realidade da empresa, pois nenhum plano ou estratégia resiste à falta de recursos. A compreensão da filosofia do marketing deve ser internalizada e compreendida claramente e, na medida do possível, os colaboradores devem estar envolvidos nesse processo. Enfim, o plano de marketing deve ser amplamente disseminado na empresa e contar com um acompanhamento constante. 
Dessa forma, Sarquis (2003) propõe um modelo simplificado de planos de marketing para pequenas empresas, que deve iniciar-se com a realização de um diagnóstico sobre a posição que a empresa ocupa no mercado, passando pela análise das possíveis barreiras e oportunidades que o mercado oferece, pelo estabelecimento de objetivos e definição de estratégias para atingi-los, pela definição das ações necessárias, pessoal responsável e recursos envolvidos, pela definição de um cronograma de implementação das ações e, finalmente, pelo estabelecimento de indicadores para acompanhamento do plano traçado.

De acordo com esse mesmo autor, o plano de marketing para a pequena empresa deve focar principalmente os resultados e ações mercadológicas que a auxiliem no alcance de seus objetivos; deve ser realista, converter objetivos em ações concretas, produtivas e estar direcionado para melhorar o desempenho e lucratividade da empresa. À princípio, as exigências metodológicas e operacionais do planejamento podem representar alguma preocupação para a pequena empresa; no entanto, é provável que, depois da segunda ou terceira experiência, a empresa apresente maior desenvoltura, segurança e rapidez na sua realização.

O planejamento de marketing não substitui o planejamento estratégico da pequena empresa, e deve ser elaborado em função das diretrizes e objetivos estabelecidos pela sua alta direção. O acompanhamento das diretrizes de marketing da pequena empresa, junto com os acompanhamentos técnico, financeiro e de recursos humanos, devem ser utilizados como fonte de informação para a retroalimentação do planejamento estratégico.

\section{$2.8 \quad$ Gestão de Pessoas}

Toda e qualquer organização depende do empenho de indivíduos - em princípio, para o seu estabelecimento enquanto negócio ou empreendimento; posteriormente, para a sua operacionalização. Sendo assim, as pessoas e suas competências são elementos estratégicos e essenciais para o alcance da competitividade de uma organização e sua manutenção. 
A importância das pessoas no contexto das empresas e a competitividade fizeram com que a preocupação com a sua gestão ganhasse um espaço cada vez maior na teoria organizacional, desencadeando, dessa forma, o conceito de modelo de gestão de pessoas.

Segundo Fischer (2002), gestão de pessoas é a maneira pela qual as empresas se organizam para gerenciar e orientar o comportamento humano no trabalho. Para isso, estruturam-se definindo princípios, estratégias, políticas e práticas ou processos de gestão e, através desses mecanismos, implementam diretrizes e orientam o estilo de atuação dos gestores em sua relação com aqueles que nelas trabalham.

O modelo de gestão de pessoas adotado pelas empresas é influenciado tanto por fatores internos como por fatores externos, e para os diferentes contextos históricos e setoriais existem diferentes modalidades de gestão. Tudo que interfere de alguma maneira nas relações organizacionais pode ser considerado um componente do modelo de gestão de pessoas, e o comportamento organizacional não é produto direto de um processo de gestão, mas o resultado das relações pessoais, interpessoais e sociais que ocorrem na empresa.

Para Chiavenato (1999), de acordo com a Tabela 2.17, o processo básico da gestão de pessoas é constituído por quatro subprocessos interdependentes: provisão; aplicação; manutenção; desenvolvimento; monitoração.

\begin{tabular}{|c|l|}
\hline \multicolumn{2}{|c|}{ Tabela 2.17: Os cinco subprocessos básicos na Gestão de Pessoas, segundo Chiavenato } \\
\hline \hline PROVISÃO) & Quem trabalhará na organização \\
\hline APLICAÇÃO & O que as pessoas farão na organização \\
\hline \hline MANUTENÇÃO & Como manter as pessoas trabalhando na organização \\
\hline \hline DESENVOLVIMENTO & Como preparar e manter pessoas \\
\hline \hline MONITORAÇÃO & Como saber quem são e o que fazem as pessoas \\
\hline
\end{tabular}




\subsubsection{Processo de provisão de pessoas para a organização}

De acordo com Chiavenato (1999), a provisão é a primeira etapa do processo de gestão de pessoas, onde são realizados o planejamento de pessoal, o recrutamento e a seleção. O planejamento de pessoal cuida da necessidade de pessoas para que os objetivos organizacionais sejam atingidos, dentro de determinado período de tempo. Trata-se de antecipar qual a força de trabalho e quais as competências necessárias para a realização da ação organizacional.

Aspectos como a rotatividade de pessoal e o absenteísmo devem ser levados em consideração durante o planejamento da provisão de pessoas. Rotatividade de pessoal é o termo utilizado para definir a flutuação de pessoas na organização, e pode ocorrer em consequência de fatores internos ou externos à empresa.

O autor cita como fatores externos que podem influenciar a rotatividade de pessoal a oferta de postos de trabalho no mercado e a conjuntura econômica. Quanto aos fatores internos, estes podem estar relacionados à política salarial da organização, política de benefícios, política de recrutamento ou até mesmo a falta de políticas referentes a esses aspectos, tipo de supervisão, oportunidades de crescimento profissional oferecidas pela organização, condições físicas e ambientais de trabalho, cultura organizacional, critérios e programas de treinamento e critérios de avaliação de desempenho.

Utiliza-se a expressão absenteísmo para designar as faltas ou ausências dos colaboradores. Num sentido mais amplo, é a soma dos períodos de ausência dos empregados, seja por falta, atraso ou algum motivo interveniente.

A etapa posterior ao planejamento de pessoal, dentro do subprocesso de provisão, é o recrutamento. Ainda segundo Chiavenato (2000), o recrutamento tem como objetivo atrair os candidatos potencialmente qualificados e capazes de ocupar os cargos disponíveis na empresa.

De acordo com Faissal et al. (2005), a empresa, ao delinear sua estratégia de atração, deve partir de informações relativas a oferta de profissionais no mercado de trabalho, bem como de propostas oferecidas pelos concorrentes. Para estes autores, 
as empresas que desejam atrair profissionais competentes devem cuidar de suas imagens, precisam definir claramente suas demandas, requisitos básicos e perfis de competências, além de terem políticas que valorizem o capital humano, oferecendo aos colaboradores oportunidades de desenvolvimento e crescimento em suas carreiras.

Conforme a Tabela 2.18, Etapas do recrutamento, inicia-se o processo em função do planejamento de provisão de pessoas, que tem como objetivo apontar a necessidade de contratação ou realocação de pessoas na empresa, passando pela captação de candidatos, divulgação das vagas, definição do conteúdo de recrutamento, recepção dos candidatos e, finalmente, triagem e encaminhamento para seleção.

\begin{tabular}{|c|c|}
\hline \multicolumn{2}{|r|}{ Tabela 2.18: Etapas do Recrutamento } \\
\hline ETAPA & PROCEDIMENTO \\
\hline Definição das vagas & $\begin{array}{l}\text { Em função do planejamento de provisão de pessoas, devem ser } \\
\text { definidas as vagas de trabalho, remuneração, tempo de } \\
\text { preenchimento da vaga e requisitos quanto à formação, } \\
\text { competências e habilidades dos possíveis candidatos. }\end{array}$ \\
\hline $\begin{array}{l}\text { Análise das fontes de } \\
\text { recrutamento e meios de } \\
\text { atração }\end{array}$ & $\begin{array}{l}\text { São denominados meios de atração todos os veículos utilizados } \\
\text { pela organização para divulgar as vagas, tanto interna quanto } \\
\text { externamente. Algumas variáveis devem ser levadas em } \\
\text { consideração para a adequada escolha das fontes de } \\
\text { recrutamento e meios de atração. São elas: natureza das } \\
\text { atribuições dos candidatos potenciais; relação oferta e demanda } \\
\text { do mercado; recursos disponíveis na organização (financeiro, } \\
\text { pessoal, tecnologia), tempo previsto para preenchimento da vaga. }\end{array}$ \\
\hline $\begin{array}{c}\text { Comunicação inicial com os } \\
\text { candidatos e estabelecimento } \\
\text { de estratégia para atrair } \\
\text { candidatos }\end{array}$ & $\begin{array}{l}\text { Devem ser definidas as informações a serem inseridas na } \\
\text { comunicação inicial com os possíveis candidatos, de forma a } \\
\text { atraí-los e interessá-los para a vaga existente. }\end{array}$ \\
\hline $\begin{array}{l}\text { Recepção dos candidatos e } \\
\text { informações pertinentes }\end{array}$ & $\begin{array}{l}\text { Deve ser definida a forma de recepção das informações dos } \\
\text { candidatos potenciais e ferramentas pertinentes (Curriculum Vitae, } \\
\text { ficha padrão da organização, etc.). }\end{array}$ \\
\hline Triagem inicial dos candidatos & $\begin{array}{l}\text { Recebidas as informações iniciais dos candidatos potenciais, } \\
\text { devem ser estabelecidos os critérios para triagem e definição ou } \\
\text { não do encaminhamento para a etapa de seleção. }\end{array}$ \\
\hline
\end{tabular}

Após o recrutamento, inicia-se a etapa de seleção. Segundo Chiavenatto (2000), a seleção de pessoal é um processo de comparação entre as qualificações de cada um dos candidatos e as exigências do cargo, resultando na escolha do candidato mais apto para exercer a função proposta. 
As técnicas de seleção auxiliam os responsáveis pela condução desse processo, para que a tomada de decisão final tenha qualidade. De acordo com Faissal; Passos; Mendonça e Almeida (2005), destacam-se como técnicas de seleção de pessoal os testes, as dinâmicas de grupo e entrevistas. A vantagem observada para aplicação de testes é que oferecem a garantia de objetividade para a seleção, e podem ser agrupados em duas categorias: os testes psicológicos e os de conhecimento.

Outra técnica também utilizada na seleção de candidatos é a dinâmica de grupo, que consiste em propor a um grupo de candidatos um conjunto de atividades, tais como: vivência de jogos, simulações, testes situacionais, estudos de caso ou debates sobre temas específicos. De maneira geral, as dinâmicas de grupo são indicadas para avaliar habilidades interpessoais e atitudes, pois atuam como estímulo para deflagrar a interação entre os participantes e promover uma dinâmica de funcionamento que possibilite a observação direta do comportamento dos candidatos.

Para os autores, alguns cuidados devem ser tomados na condução de uma dinâmica de grupo, a saber:

$\checkmark$ As dinâmicas devem iniciar-se com uma atividade de apresentação e integração do grupo.

$\checkmark$ Devem incluir atividades lúdicas.

$\checkmark$ Recomenda-se no mínimo oito e no máximo doze candidatos para participação na dinâmica.

$\checkmark$ Recomenda-se no mínimo dois observadores participando da dinâmica, sendo que um deve ser, de preferência, o chefe imediato para a posição.

A terceira técnica utilizada para seleção é a entrevista. Segundo Chiavenatto (1999), esta é a técnica mais empregada nas grandes e médias empresas e, de acordo com Faissal; Passos; Mendonça e Almeida (2005), consiste na proposição de perguntas aos candidatos que objetivam avaliar as suas competências. Podem ser classificadas quanto ao grau de estruturação (estruturadas ou não-estruturadas), 
quanto ao tipo de informação que se deseja obter (técnicas ou psicológicas), e quanto a forma de realização (tradicional ou situacional).

Tão importante quanto o processo de contratação de um novo colaborador para uma organização é o processo de desligamento, que pode ocorrer em função de aposentadoria, de pedido (por parte do colaborador) ou de demissão (partindo da própria empresa). Essa é uma das tarefas mais ingratas dos gestores, especialmente quando se trata de bons profissionais demitidos por motivos fora do seu controle, e deve ser conduzida de forma tão séria e planejada quanto a admissão.

Segundo Lacombe (2005), a decisão relacionada a demissão de um colaborador não deve ficar à critério de uma só pessoa, embora o chefe imediato tenha uma parcela significativa nesse processo. Para o autor, as atitudes dos demitidos tendem a ser fortemente influenciadas pela emoção; para tanto, é importante evitar armadilhas no processo que possam levá-los a problemas pessoais posteriores.

\subsubsection{Aplicação, monitoração e manutenção das pessoas na organização}

Partindo do modelo de gestão de pessoas estabelecido por Chiavenatto (1999), verifica-se que os subprocessos aplicação, manutenção e monitoração estão intimamente relacionados. A aplicação e monitoração diz respeito à análise e desenho de cargos, bem como à definição de remuneração e método de avaliação, enquanto que a manutenção diz respeito aos fatores motivacionais, que referem-se, entre outros, à organização da gestão de pessoas e a remuneração.

De acordo com Lacombe (2005), a descrição de cargos deve ser genérica, e deve abranger as diversas funções nele incluídas. Descreve-se o que fazem os ocupantes do cargo, e os requisitos básicos exigidos (competências, formação, tempo de experiência). Devem ser estabelecidos um título para o cargo, de preferência com base em denominações predominantes no mercado, e os critérios para avaliação dos profissionais, bem como as faixas de remuneração. 
A remuneração é um dos aspectos mais motivadores numa organização. Em contrapartida, um dos fatores mais desmotivantes para um profissional é considerarse injustiçado em sua remuneração, pois ela afeta não somente sua vida material, mas o bem-estar psicológico. Dessa forma, a coerência entre as remunerações concedidas ao pessoal de uma empresa é fator fundamental.

Após a definição dos cargos e faixas de remuneração, devem ser definidos os critérios de avaliação. De acordo com Hipólito e Reis (2002), as avaliações fazem parte do cotidiano de qualquer empresa e são necessárias para averiguar as correções das ações organizacionais e identificar as necessidades de revisão e melhoria. A vantagem de estruturar o processo de avaliação e introduzi-lo como prática formal nas organizações está em produzir ferramentas comuns aos diversos gestores e profissionais vinculados aos objetivos e estratégias das organizações.

Ao abordarem os cuidados na implementação de um processo de avaliação, os autores destacam que o campo de avaliação de pessoas é repleto de nuances e subjetividade. Isso significa que um dos principais problemas associados ao sistema de avaliação refere-se às diferenças de percepção dos envolvidos, o que pode comprometer a precisão das avaliações. Para tanto, devem ser tomados os seguintes cuidados: utilização de critérios claros, negociados e legitimados; ampla comunicação dos objetivos, etapas e impactos do processo; capacitação dos avaliadores e avaliados quanto às ferramentas utilizadas; apresentação da avaliação como elemento de apoio ao desenvolvimento organizacional; e adoção de uma sistemática que transcenda a dimensão unidirecional chefe-subordinado, estimulando a autoavaliação e avaliação com múltiplas fontes.

A manutenção das pessoas na organização passa por critérios pessoais que estão intimamente ligados à motivação. Segundo Casado (2002), a motivação tem sido um dos temas mais estudados em Gestão de Pessoas e, mesmo assim, permanece como um dos aspectos mais preocupantes no cotidiano das organizações. De acordo com Pieron (1964) apud Casado (2002), num sentido mais amplo, na psicologia, motivação corresponde a uma modificação do organismo que o faz mover-se, até que se reduza essa modificação. 
Como explica Casado (2002), a motivação tem sido vista como uma saída para melhorar o desempenho profissional no que diz respeito tanto à produtividade quanto à saúde organizacional e à satisfação dos trabalhadores. Nesse sentido, é fundamental que a empresa e os indivíduos que nela atuam estejam conscientes dos fatores que levam à motivação.

Para o autor, o papel do gestor nesse contexto é o de identificar os norteadores de comportamento dos colaboradores e definir as estratégias motivacionais compatíveis com os objetivos da organização e com o crescimento de cada integrante de seu grupo de trabalho.

Segundo Vergara (2000), cabe ao colaborador refletir sobre as formas de reconhecimento que interferem positivamente no seu trabalho e que, consequentemente, o motivarão, pois as pessoas e suas motivações diferem umas das outras. Existem indivíduos que sentem-se motivados por fatores econômicofinanceiros, enquanto que outros motivam-se através do reconhecimento, por serem chamados a participar de decisões ou tarefas desafiadoras.

\subsubsection{Desenvolvimento das pessoas}

De acordo com Lacombe (2005), a responsabilidade pelo desenvolvimento de cada pessoa é dela própria; as organizações devem agir como facilitadoras e apoiadoras do desenvolvimento de cada um, e tomar iniciativa em casos que sejam de seu interesse, pois precisam dispor de pessoas competentes e motivadas.

Atualmente, as empresas não podem se dar ao luxo de escolher se treinam ou não os seus colaboradores, porque, normalmente, as pessoas são admitidas com qualificações genéricas e todas as empresas possuem peculiaridades que as diferenciam umas das outras. A principal razão que leva as empresas a adotarem o treinamento é proporcionar ao colaborador novas habilitações ou melhorar as que ele já possui. Outros aspectos que motivam as empresas a adotarem a prática do contínuo aperfeiçoamento de seus colaboradores são: os bons profissionais gostam 
de aprender e evoluir; o treinamento contribui para atrair e reter bons profissionais; atualmente, as exigências do mercado avançam velozmente e, sendo assim, a empresa deve estar apta para adaptar-se às constantes mudanças.

Ainda citando Lacombe (2005), os treinamentos classificam-se basicamente quanto a sua forma de execução (no trabalho, formal interno, formal externo ou à distância) e quanto ao público-alvo (integração de novos colaboradores, formação de trainees, capacitação técnico-profissional, estágios e desenvolvimento de executivos).

O autor destaca como riscos de investimento em treinamento a saída das pessoas treinadas e a dificuldade de calcular o retorno dos investimentos. Para que os riscos sejam minimizados, é necessário que os programas de treinamento estejam alinhados aos planos estratégicos da empresa.

Apesar da importância da formação e sua constante reciclagem, atualmente verificase nas organizações que o desenvolvimento pessoal alinhado aos objetivos e estratégias da empresa ultrapassam a formação técnica formal.

Nesse sentido, segundo Fleury et al. (2002), a partir da década de 1970, o termo "competência" tem sido intensamente debatido tanto no meio corporativo quanto no meio acadêmico, e nasceu do questionamento do conceito de qualificação e do processo de formação profissional, principalmente técnica. De acordo a autora, o termo competência é definido como um saber agir responsável e reconhecido, que implica em mobilizar, integrar, transferir conhecimentos, recursos e habilidades que agreguem valor econômico à organização e valor social ao indivíduo.

2.8.3.1 Aspectos comportamentais relacionados a gestão de pessoas

Neste trabalho, a análise dos aspectos comportamentais relacionados a gestão de pessoas nas organizações terá início a partir da relação que se estabelece entre o indivíduo e seu grupo de trabalho.

De acordo com Casado (2002), as organizações contemporâneas entenderam a necessidade de conhecer o ser humano e as interações que empreende para 
reafirmar-se como ser produtivo, bem como a influência que os grupos e organizações exercem sobre as condutas individuais dos colaboradores. Ainda segundo a autora, as pessoas que compõem a organização trazem para o ambiente de trabalho todo o seu jeito de ser, sentir e viver. São motivações diferentes, habilidades, aptidões diversas e competências distintas que precisam conviver e produzir. Esse dilema entre a individualidade e a participação no coletivo necessita de atenção e cuidados por parte dos gestores.

Como consequência da interação social que naturalmente ocorre nas empresas, surgem as lideranças que, segundo Fleury et al. (2002), consistem num processo social onde se estabelecem relações de influências entre as pessoas. O núcleo desse processo de interação humana é composto do líder ou líderes, seus liderados, um fato e um momento social.

Conforme as autoras, de forma geral, o cenário atual no qual se encontram a maior parte das organizações é caracterizado pela descentralização do poder, influência de diversos atores sobre as organizações, aumento da qualificação e do nível de informação do trabalhador, além de turbulências ambientais e, nesse contexto, a atuação dos líderes nas empresas tem se tornado cada vez mais importante. Tornase necessário que o líder deixe de ser um controlador para ser um facilitador. Esse indivíduo deve atuar como o profissional que busca soluções estratégicas não só a curto prazo e, ao invés de disciplinar seus subordinados, deve cultivar o comprometimento.

Outro aspecto decorrente da interação social que acontece nas empresas está relacionado à ética, pois, segundo Lacombe (2005), nenhum grupo pode sobreviver sem um conjunto de princípios e normas que definam o tipo de comportamento socialmente aceito. De acordo com o autor, a empresa que possui conduta ética atrai e retém colaboradores, clientes e fornecedores éticos responsáveis.

As diferenças entre as pessoas é também um aspecto comportamental relevante na gestão das pessoas. Segundo Vergara (2000), as diferenças podem estar fundamentadas nos valores e nas crenças das pessoas, no mundo e nas motivações que as conduzem, bem como nos diversos tipos de inteligência (musical, lógicomatemática, linguística, interpessoal), habilidades e competências. 
Dessa maneira, todos os indivíduos possuem os tipos de inteligência apontados; no entanto, uma predomina sobre a outra. A diversidade nos grupos, tanto do ponto de vista das inteligências quanto dos valores, crenças, habilidades e competências, se bem aproveitada e gerida, pode transformar-se numa vantagem competitiva para a empresa.

\subsection{Gestão por Desempenho}

De acordo com Maximiniano (2002), todas as organizações são sistemas de recursos que perseguem objetivos. Portanto, 0 desempenho de qualquer organização pode ser avaliado pela medida com que os objetivos são realizados e pela forma com que os recursos são utilizados. Nesse sentido, o autor afirma que os critérios básicos para mensurar a avaliação de desempenho das organizações são: eficiência, eficácia e competitividade.

A eficiência é um princípio da administração de recursos e está relacionada à forma como são utilizados os recursos na organização, e significa realizar atividades ou tarefas da maneira certa, econômica e racional, com o mínimo de esforço e o maior aproveitamento possível dos recursos.

A eficácia é o conceito de desempenho que envolve a comparação entre objetivos (desempenho esperado) e resultados (desempenho realizado).

A competitividade é uma tradução particular da idéia de eficácia que se aplica particularmente a empresas. Empresa competitiva é aquela que consegue transformar grande número de pessoas em clientes, obter lucro e sobreviver com isso, ou ainda quando possui alguma vantagem sobre seus concorrentes, o que a faz ser preferida pelo cliente, ser mais competente em alguma forma de relacionamento com o ambiente, ou dispor de algum recurso singular.

De acordo com Bateman e Snell (1998), a gestão por desempenho é uma abordagem contemporânea no pensamento da administração resultante das abordagens clássicas (administração sistemática, científica, burocracia, gestão 
administrativa, relações humanas), baseada em princípios de aprendizado contínuo, flexibilidade e administração participativa.

Para Souza, Mattos, Sardinha e Alves (2005), gerir o desempenho significa avaliar a extensão da discrepância, identificar os fatos geradores dessa situação e, em seguida, intervir tomando decisões para eliminar as variáveis constituídas em fontes de problemas.

Nesse sentido, Stoffel (1997) define a administração do desempenho como uma metodologia gerencial que visa promover o alcance de metas organizacionais e o desenvolvimento dos recursos humanos, através de um processo participativo, dinâmico, contínuo e sistematizado de planejamento, acompanhamento, avaliação e melhoria do desempenho.

\subsubsection{Administração por desempenho como método}

Conforme já citado anteriormente, a administração por desempenho é uma abordagem baseada nos princípios do aprendizado contínuo, entre outros. Bateman e Snell (1998) definem organizações que aprendem como proativas, ou seja, empresas que são flexíveis e possuem habilidade para mudar e aprender continuamente. Nesse sentido, os autores definem como organizações de aprendizagem aquelas que possuem habilidade para criar, adquirir e transferir conhecimento, de modificar seu comportamento para refletir sobre novos conhecimentos.

Outro aspecto relevante está relacionado à administração participativa. Nas organizações de alto envolvimento, a alta administração deve garantir a existência de consenso entre todos os níveis e áreas sobre a direção para a qual caminha a empresa. Forças-tarefa, grupos de estudo e outras técnicas são utilizadas para promover a participação em decisões que afetam toda a organização. Dentro dessa sistemática de trabalho, é fundamental oferecer um retorno contínuo quanto ao desempenho e quanto à medida de eficácia com que estão cumprindo o programa estratégico. 
De acordo com Souza et al. (2005), a trajetória da administração por desempenho consiste em estabelecer um processo com o objetivo de agregar valor e propiciar retornos e informações de forma sistemática. Nesse sentido, Stoffel (1997) aponta que o ciclo da administração por desempenho é composto por três etapas: planejamento, acompanhamento e avaliação.

Para o autor, trata-se de um processo sistematizado por apresentar uma metodologia com características próprias e diferenciadas, que agrega etapas e sequências bem definidas, com a finalidade de atingir resultados previamente estabelecidos. Este método possui como objetivos gerais: possibilitar o alcance de metas organizacionais e promover o desenvolvimento das pessoas. Como objetivos específicos, procura estimular os gerentes e colaboradores a negociarem metas, criando um compromisso mútuo com os resultados, definirem padrões esperados de desempenho, promoverem as condições necessárias para alcançar o padrão de desempenho pré-estabelecido e promoverem melhorias constantes do trabalho e do desenvolvimento profissional.

Nas Tabelas 2.19, 2.20 e 2.21 estão detalhadas as etapas do método da gestão por desempenho: planejamento, acompanhamento e avaliação do desempenho. 
Tabela 2.19: Etapas do Método da Administração por Desempenho segundo Stoffel (1997): Planejamento

\begin{tabular}{|c|c|c|}
\hline OBJETIVO & & DETALHAMENTO \\
\hline \multirow[t]{2}{*}{$\begin{array}{l}\text { Planejamento do Desempenho: A administração } \\
\text { por desempenho é um método que permite } \\
\text { expressar o planejamento empresarial ao nível } \\
\text { de competência de cada indivíduo, dirigindo } \\
\text { seus esforços para o atingimento das metas } \\
\text { estabelecidas. Por outro lado, para que se } \\
\text { obtenha o máximo de rendimento da } \\
\text { administração por desempenho é necessário } \\
\text { que se tenha um planejamento empresarial } \\
\text { suficiente para ultrapassar os limites de metas de } \\
\text { continuidade e melhoria, e impulsionar a } \\
\text { organização com metas de inovação. }\end{array}$} & 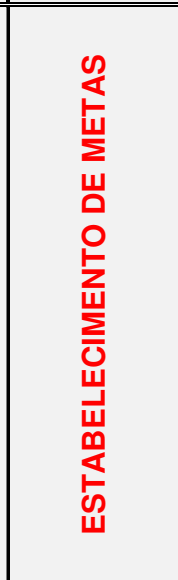 & $\begin{array}{l}\text { As metas são resultados a serem atingidos, que } \\
\text { contribuem para o sucesso da organização } \\
\text { Nesse sentido, é importante que cada unidade } \\
\text { defina suas metas específicas de acordo com o } \\
\text { estabelecido no planejamento empresarial. Ao } \\
\text { definirem as metas, gerente e colaborador devem } \\
\text { atender os seguintes critérios: } \\
\text { Devem expressar as metas empresariais. } \\
\text { Devem ater-se ao nível de competência } \\
\text { do colaborador. } \\
\text { Devem ser específicas, ou seja, bem } \\
\text { delimitadas e sem ambigüidades. } \\
\text { Devem representar resultados e não } \\
\text { atividades ou processos. } \\
\text { Devem ser redigidas de forma objetiva, } \\
\text { direta e simples. }\end{array}$ \\
\hline & \multirow{5}{*}{ 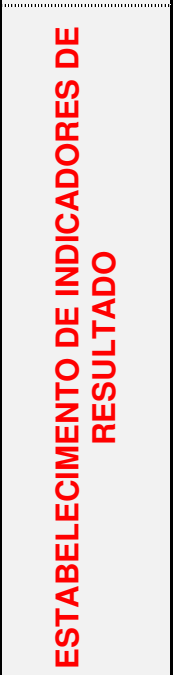 } & \multirow{5}{*}{$\begin{array}{l}\text { Para cada meta, são estabelecidos indicadores } \\
\text { dos resultados esperados, que vão orientar o } \\
\text { desempenho do colaborador ao longo do ciclo, } \\
\text { permitir o acompanhamento por parte do gerente } \\
\text { e, ao final, medir o desempenho (resultados } \\
\text { esperados x resultados realizados). Os } \\
\text { indicadores devem ser descritos de modo: } \\
\text { a) Preciso: exato e objetivo. } \\
\text { b) Mensurável: que permita o confronto entre o } \\
\text { esperado e o realizado. } \\
\text { c) Gerenciável: que esteja no âmbito de } \\
\text { competência do gerente e do colaborador. } \\
\text { Os indicadores podem ser representados por: } \\
\text { Índices qualitativos; } \\
\text { Prazo; } \\
\text { Índices quantitativos; } \\
\text { Custo. }\end{array}$} \\
\hline & & \\
\hline \multirow[t]{3}{*}{ DIRETRIZES/ METAS EMPRESARIAIS } & & \\
\hline & & \\
\hline & & \\
\hline & \multirow{3}{*}{ 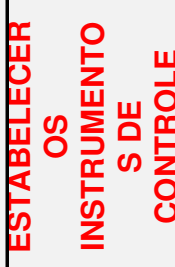 } & \multirow{3}{*}{$\begin{array}{l}\text { Para cada um dos indicadores ou para seu } \\
\text { conjunto de metas, deve ser definido um } \\
\text { instrumento de controle que registre os } \\
\text { resultados realizados e que possa servir como } \\
\text { base de comparação. Podem ser demonstrativos, } \\
\text { relatórios, índices absolutos ou percentuais, } \\
\text { cronogramas, controles diversos, etc. }\end{array}$} \\
\hline \multirow[t]{3}{*}{ PLANO INDIVIDUAL DE TRABALHO } & & \\
\hline & & \\
\hline & 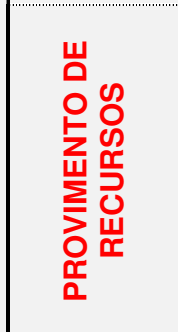 & $\begin{array}{l}\text { À empresa cabe não apenas a iniciativa de } \\
\text { negociar as metas, mas também de gerar as } \\
\text { condições necessárias à sua consecução. Com o } \\
\text { objetivo de proporcionar os recursos adequados } \\
\text { para a operacionalização das metas, devem se } \\
\text { observados os obstáculos relacionados à falta de } \\
\text { orientação, à situação de trabalho, à falta de } \\
\text { estímulo, à condições de ordem pessoal e } \\
\text { relacionados à qualificação. }\end{array}$ \\
\hline
\end{tabular}


Tabela 2.20: Etapas do Método da Administração por Desempenho segundo Stoffel (1997): Acompanhamento do Desempenho

\begin{tabular}{|c|c|c|}
\hline OBJETIVO & & DETALHAMENTO \\
\hline $\begin{array}{l}\text { Atuando proativamente, com vistas a atingir } \\
\text { um desempenho pleno ou superior, o } \\
\text { acompanhamento do desempenho possui } \\
\text { como objetivos: } \\
\text { a) revisar as metas e os respectivos } \\
\text { indicadores, dando ênfase especial às } \\
\text { metas de maior relevância, que são as } \\
\text { que trazem maior retorno e merecem } \\
\text { maior investimento; } \\
\text { b) alterar metas e/ou indicadores, } \\
\text { ajustando-os à dinâmica da organização } \\
\text { e/ou à capacidade de realizá-las do } \\
\text { colaborador ou da empresa; } \\
\text { c) identificar desvios de desempenho e agir } \\
\text { sobre as suas causas, estabelecendo um } \\
\text { plano de recuperação e apoio; } \\
\text { d) avaliar as metas já atingidas; } \\
\text { e) estabelecer novas metas. }\end{array}$ & 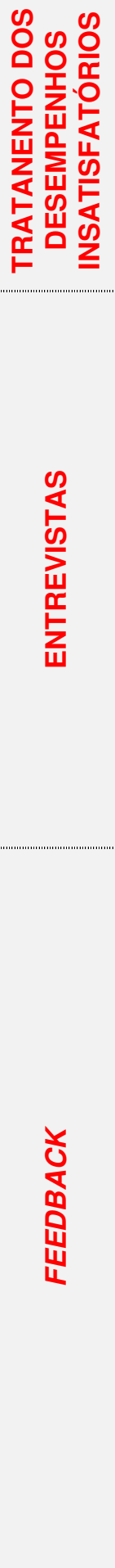 & $\begin{array}{l}\text { As entrevistas de acompanhamento ou } \\
\text { avaliação do desempenho não devem ser } \\
\text { razão de preocupação, pois são, antes de } \\
\text { mais nada, um encontro profissional, } \\
\text { portanto, de pessoas adultas e capacitadas } \\
\text { quanto ao relacionamento interpessoal. } \\
\text { Para que as reuniões ocorram de forma } \\
\text { adequada, devem ser tomados os seguintes } \\
\text { cuidados: } \\
\text { a As metas da organização devem ser } \\
\text { conhecidas por todos. } \\
\text { Devem ser desenvolvidas as habilidades } \\
\text { de negociação. } \\
\text { Os envolvidos devem saber ouvir e } \\
\text { respeitar as opiniões alheias. } \\
\text { Os gestores devem assumir uma posição } \\
\text { de apoio e orientação. } \\
\text { a) Os indicadores de desempenho permitem } \\
\text { o autofeedback e possibilitam correções } \\
\text { imediatas, tornando a avaliação mais } \\
\text { objetiva. } \\
\text { b) O feedback deve ater-se à descrição de } \\
\text { desempenhos que possam ser ser } \\
\text { comprovados. Emitir julgamento de } \\
\text { desempenho ou da pessoa produz } \\
\text { reações defensivas. Comportamentos só } \\
\text { devem ser considerados quando forem } \\
\text { críticos à realização do desempenho. } \\
\text { c) O feedback deve ser específico, deve } \\
\text { descrever um desempenho ou fato em } \\
\text { particular de forma que seja útil às ações } \\
\text { preventivas ou corretivas. } \\
\text { d) O feedback deve ser oportuno, isto é, } \\
\text { ocorre imediatamente após o fato. } \\
\text { e) O feedback deve ser mensurável. O } \\
\text { registro dos resultados (desempenho } \\
\text { realizado) deve favorecer a comparação } \\
\text { com desempenho esperado (indicadores } \\
\text { pré-estabelecidos). }\end{array}$ \\
\hline
\end{tabular}


Tabela 2.21: Etapas do Método da Administração por Desempenho segundo Stoffel (1997): Avaliação do Desempenho

\begin{tabular}{|c|c|c|}
\hline OBJETIVO & & DETALHAMENTO \\
\hline $\begin{array}{l}\text { A avaliação é o resultado da análise } \\
\text { comparativa entre o desempenho } \\
\text { esperado (indicadores de resultado) e o } \\
\text { desempenho realizado (resultado efetivo), } \\
\text { que permite atribuir os seguintes conceitos: } \\
\text { O resultado realizado supera o resultado } \\
\text { esperado. } \\
\text { O resultado realizado iguala o resultado } \\
\text { esperado. } \\
\text { O resultado realizado é inferior ao } \\
\text { resultado esperado. } \\
\text { O resultado esperado inexiste. }\end{array}$ & 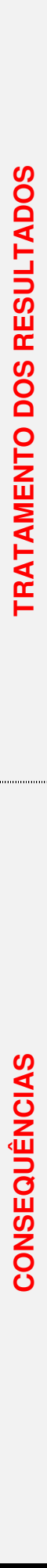 & 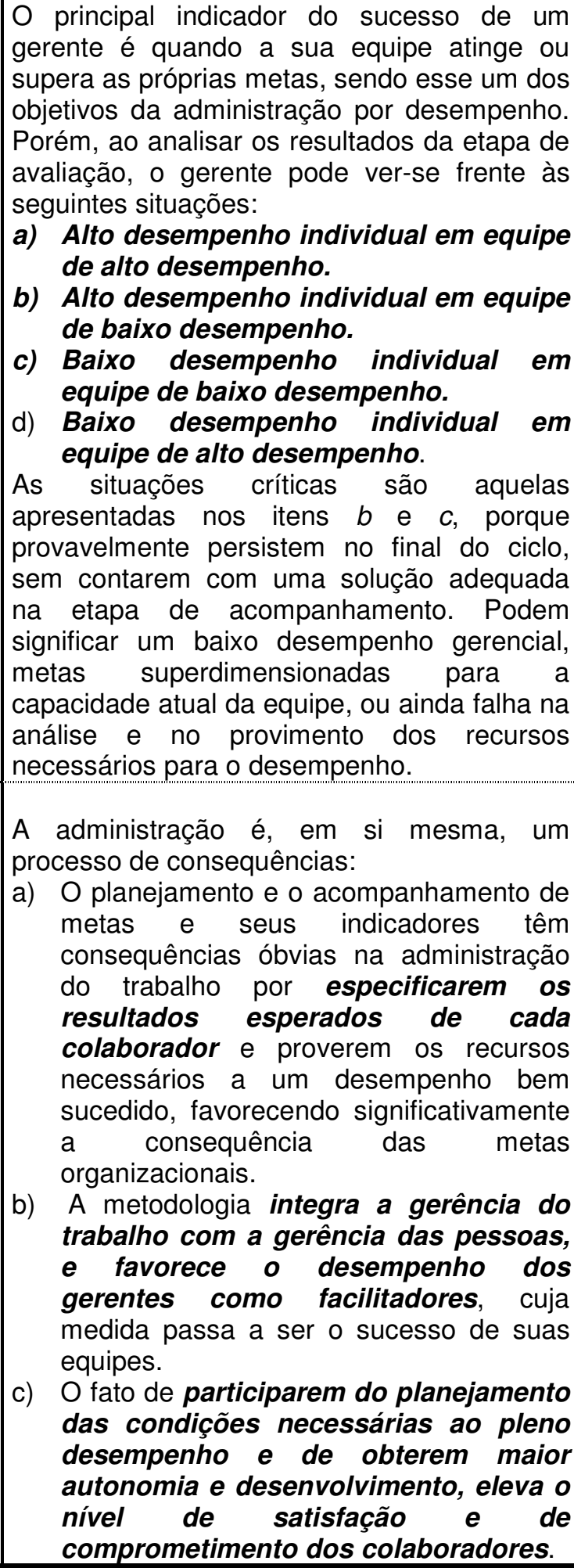 \\
\hline
\end{tabular}


Conforme o método proposto nas Tabelas 2.19, 2.20 e 2.21, Stoffel (1997) aborda dois pontos considerados fundamentais para a implementação da administração por desempenho: a existência do planejamento empresarial e de um corpo gerencial preparado. A fase de implementação trará, principalmente para todos os gestores, uma sobreposição com a metodologia gerencial vigente, ou, na ausência de uma, com a forma empírica com que se tem conduzido o desempenho dos colaboradores. A transição se fará com maior ou menor dificuldade, dependendo do grau de empenho e constância da equipe.

Outro aspecto destacado pelo autor refere-se aos cuidados no uso de resultados da avaliação do desempenho como subsídio para promoções salariais, pois trata-se de uma questão polêmica, já que o atrelamento da questão salarial à avaliação do desempenho tem limitado os demais objetivos do sistema; por outro lado, como recompensar quem o merece sem considerar o desempenho, ou ainda, se o objetivo é favorecer a coesão de equipes, como identificar, diferenciar e premiar desempenhos individuais?

De acordo com Souza et al. (2005), a administração por desempenho possibilita mensurar o que agrega valor ao sistema de gestão e, se realizado da forma adequada, favorece a concretização da estratégia e faz a diferença entre as iniciativas organizacionais bem intencionadas, porém aleatórias e acidentais, cujo destino é lugar algum. Sistemas de desempenho devem ser delineados para o atendimento da satisfação do cliente, acarretando a necessidade da interação com os demais instrumentos gerenciais para comunicar necessidades de melhoria nos níveis organizacionais.

Ainda segundo os autores, sistemas dessa natureza não devem ser confundidos com simples ferramentas. Antes, são bases de informação consistentes que agregam valor aos processos produtivos, enquanto apoiam a tomada de decisão e estimulam o fortalecimento da cultura, devido à valorização de posturas desejadas. 
De acordo com a NBR ISO 9000:2000, o sistema de gestão da qualidade representa a parte do sistema de gestão da organização, cujo enfoque é alcançar resultados com relação aos objetivos da qualidade para satisfazer às necessidades, expectativas e requisitos das partes interessadas, conforme apropriado. Os objetivos da qualidade complementam outros objetivos da organização, tais como aqueles relacionados ao crescimento, à captação de recursos financeiros, à lucratividade, ao meio ambiente, à segurança e à saúde ocupacional.

Os sistemas de gestão da qualidade propostos pela série de normas NBR ISO 9000:2000 devem ser estruturados por processos e baseados em princípios a serem utilizados pela Alta Direção da Empresa para conduzir a organização à melhoria de seu desempenho, conforme destacado na Tabela 2.22. 
Tabela 2.22: Princípios a serem utilizados na implementação de um Sistema de Gestão da Qualidade, segundo a NBR ISO 9000:200

\begin{tabular}{|c|c|}
\hline $\begin{array}{l}\text { Controle } \\
\text { Enfoque }\end{array}$ & Descrição \\
\hline Foco no Cliente & $\begin{array}{l}\text { Organizações dependem de seus clientes e, portanto, é recomendável que } \\
\text { atendam às suas atuais e futuras necessidades, aos seus requisitos e procurem } \\
\text { exceder as suas expectativas. }\end{array}$ \\
\hline Liderança & $\begin{array}{l}\text { Os líderes devem estabelecer a unidade de propósito e o rumo da organização. } \\
\text { É conveniente que eles criem e mantenham um ambiente interno no qual as } \\
\text { pessoas possam estar totalmente envolvidas no propósito de atingir os objetivos } \\
\text { da organização. }\end{array}$ \\
\hline $\begin{array}{l}\text { Envolvimento de } \\
\text { Pessoas }\end{array}$ & $\begin{array}{l}\text { As pessoas de todos os níveis são a essência de uma organização, e seu total } \\
\text { envolvimento possibilita que suas habilidades sejam usadas para o benefício da } \\
\text { organização. }\end{array}$ \\
\hline $\begin{array}{l}\text { Abordagem de } \\
\text { Processo }\end{array}$ & $\begin{array}{l}\text { Um resultado desejado é alcançado de forma mais eficiente quando as } \\
\text { atividades e os recursos relacionados são gerenciados como um processo. }\end{array}$ \\
\hline $\begin{array}{l}\text { Abordagem } \\
\text { Sistêmica para a } \\
\text { Gestão }\end{array}$ & $\begin{array}{l}\text { Identificar, entender e gerenciar os processos inter-relacionados como um } \\
\text { sistema contribui para a eficácia e eficiência da organização no sentido de atingir } \\
\text { os seus objetivos. }\end{array}$ \\
\hline Melhoria Contínua & $\begin{array}{l}\text { Convém que a melhoria contínua do desempenho global da organização seja } \\
\text { seu objetivo permanente. }\end{array}$ \\
\hline $\begin{array}{l}\text { Abordagem } \\
\text { Factual para } \\
\text { Tomada de } \\
\text { Decisão }\end{array}$ & Decisões eficazes são baseadas na análise de dados e informações. \\
\hline $\begin{array}{l}\text { Benefícios } \\
\text { Mútuos nas } \\
\text { Relações com os } \\
\text { Fornecedores }\end{array}$ & $\begin{array}{l}\text { Uma organização e seus fornecedores são interdependentes, e uma relação de } \\
\text { benefícios mútuos aumenta a capacidade de ambos para agregar valor. }\end{array}$ \\
\hline
\end{tabular}

Segundo Carvalho e Paladini (2005), os conceitos de qualidade sofreram mudanças consideráveis ao longo do tempo. De simples conjuntos de ações operacionais, centradas e localizadas em pequenas melhorias do processo produtivo, a qualidade passou a ser vista como um dos elementos fundamentais do gerenciamento das organizações, tornando-se fator crítico para a sobrevivência não só das empresas, mas também de produtos, processos e pessoas. Tal perspectiva decorre diretamente da crescente concorrência que envolve os ambientes em que atuam pessoas e organizações, e a perspectiva estratégica da qualidade não apenas cria uma visão ampla da questão, mas, principalmente, atribui a ela um papel de extrema relevância no processo gerencial das organizações. 
Quanto à estratégia de aplicação, a NBR - IS0 9001:2000 promove a adoção de uma "abordagem de processo" para o desenvolvimento, implementação de um sistema de gestão da qualidade. Esta norma define que qualquer atividade, ou conjunto de atividades que usa recursos para transformar insumos (entradas) em produtos (saídas) pode ser considerada um processo .Afirma ainda que, para as organizações funcionarem de forma eficaz, elas devem identificar e gerenciar processos interrelacionados e interativos .

No requisito 4.1 da NBR - IS0 9001:2000 é colocado que é fundamental que a empresa que deseja implementar sistema de gestão da qualidade a partir desta norma, identifique os processos necessários para o sistema de gestão da qualidade, determine a seqüência e interação destes processos, determine os critérios para o seu controle e operação de forma eficaz, assegure que os recursos e informações sejam disponibilizados para a sua perfeita operação e realize o monitoramento , medição análise destes processos com objetivo de implementar ações de forma a promover a melhoria contínua dos processos.

Quanto à implementação, entende-se que a sua eficácia está diretamente relacionada à três fatores: aplicabilidade do programa para as empresas, método de implementação do programa e conscientização e empenho por parte das empresas na implementação.

Segundo Kerzner (2001), uma metodologia de implementação de programas e projetos deve ser flexível para sua fácil adaptação e customização, deve ser compatível com a cultura organizacional da empresa e não a empresa adaptar-se e metodologia e levar-se em consideração que a metodologia consiste em um conjunto de diretrizes e o que converte essas diretrizes em sucesso é maneira como a empresa processa, suporta e executa a metodologia. Segundo este mesmo autor, uma boa metodologia de implementação de programas e projetos deve levar em consideração os trabalhos e projetos paralelos que estão em desenvolvimento na empresa.

Para Charvat (2003), o trabalho inicial de metodologia para implementação de programas e projetos acarreta no consumo de recursos, portanto não pode ser considerada como uma solução rápida e provisória, não é um método para solução 
de todos os problemas que surgem ao longo do processo e não é uma garantia para o sucesso do programa, mas ajuda a diminuir a probabilidade de insucesso.

Carvallho e Paladini(2005), recomendam para implementação de Programas de Gestão da Qualidade a metodologia denominada como Gestão de Diretrizes, que consiste em um processo de gerenciamento cuja finalidade é articular uma diretriz e um objetivo associado em :área de atuação; modos de atuação; responsabilidades e recursos e tempos.

Sobre a metodologia proposta pelos autores, é oportuno destacar qual o significado d o termo " Gestão de Diretrizes":

- Direção ( o que deseja-se conquistar e para onde caminhar);

- Objetivo ( tanto quantitativo, quanto ao longo do tempo);

- Condições de Contorno;

- Linhas Mestras (indicação das estratégias de ação).

O próximo capítulo trata do relato da pesquisa-ação realizada junto às empresa de projeto durante o PDGEP 1 e 2, com objetivo de contextualizar a pesquisa, descrição da sistematização do trabalho e dos programas propriamente ditos e análises quanto à aplicação do modelo de gestão proposto por Oliveira (2005). 


\section{PESQUISA- AÇÃO JUNTO ÀS EMPRESAS DE PROJETO}

\section{1}

\section{Contexto da Pesquisa-Ação}

Como já destacado no item 1.2 - Objetivos, a pesquisa-ação ocorreu durante o Programa de Desenvolvimento Gerencial para Empresas de Projeto, em dois grupos consecutivos de empresas de projeto (Grupo 1: de março de 2006 até abril de 2007, e Grupo 2: de setembro de 2007 até maio de 2008).

Sobre as características das empresas, tanto o Grupo 1 quanto o Grupo 2 enquadram-se nos parâmetros estabelecidos pela Resolução n GMC 59/98, do MERCOSUL, e nos parâmetros fixados pelo Estatuto da Microempresa e Empresa de Pequeno Porte, através da Lei o 9.841/99 (microempresas ou empresas de pequeno porte, ou seja, tratam-se de empresas fornecedoras dos serviços de projeto, contando com até 30 colaboradores, com faturamento anual inferior a $U \$ 1,5$ milhão).

Conforme as Tabelas 3.1 e 3.2, verifica-se que tanto o Grupo 1 quanto o Grupo 2 são bastante heterogêneos se analisadas as especialidades de projeto, tempo de atuação, número de colaboradores, perfil dos titulares (formação, faixa etária, estilo de comando) e tipologias de projetos oferecidos pela empresas. 


\begin{tabular}{|c|c|c|c|c|c|}
\hline Empresa & \begin{tabular}{||c||} 
Formação \\
do(s) \\
Titulares \\
(s) \\
\end{tabular} & \begin{tabular}{|c|} 
Número \\
de \\
Colaborad \\
ores Fixos
\end{tabular} & Tipologia de projetos desenvolvidos & $\begin{array}{l}\text { Tempo de } \\
\text { Existência }\end{array}$ & $\begin{array}{l}\text { Número de } \\
\text { Colaboradores } \\
\text { Especialistas }\end{array}$ \\
\hline A & Arquitetura & 12 & $\begin{array}{c}\text { Projetos de Arquitetura, compatibilização, } \\
\text { coordenação e consultoria sobre } \\
\text { legislação na área de Arquitetura }\end{array}$ & 15 anos & 10 \\
\hline B & Arquitetura & 4 & $\begin{array}{c}\text { Projetos de Arquitetura, compatibilização, } \\
\text { coordenação e detalhamento } \\
\text { arquitetônico }\end{array}$ & 5 anos & 4 \\
\hline C & Arquitetura & 4 & Projetos de Arquitetura & 8 anos & 4 \\
\hline $\mathrm{D}$ & Arquitetura & 2 & $\begin{array}{l}\text { Projetos de Arquitetura para Empresas, } \\
\text { Condomínios Residenciais, Arquitetura } \\
\text { de Interiores para apartamentos } \\
\text { residenciais }\end{array}$ & 3 anos & 2 \\
\hline E & $\begin{array}{c}\text { Engenharia } \\
\text { Elétrica e } \\
\text { Engenharia } \\
\text { Civil }\end{array}$ & 18 & $\begin{array}{l}\text { Projetos de instalações elétricas, } \\
\text { hidráulicas e de proteção contra } \\
\text { incêndios para empreendimentos } \\
\text { residenciais, comerciais e industriais }\end{array}$ & 4 anos & 16 \\
\hline $\mathrm{F}$ & Arquitetura & 8 & $\begin{array}{l}\text { Projetos de Arquitetura de diversas } \\
\text { tipologias, com ênfase em Edifícios de } \\
\text { Escritório }\end{array}$ & 27 anos & 7 \\
\hline G & Arquitetura & 5 & $\begin{array}{c}\text { Projetos de Arquitetura, compatibilização, } \\
\text { coordenação, projetos para produção }\end{array}$ & 1 ano & 3 \\
\hline $\mathrm{H}$ & $\begin{array}{c}\text { Engenharia } \\
\text { Elétrica e } \\
\text { Civil }\end{array}$ & 28 & $\begin{array}{l}\text { Projetos de Sistemas elétricos e } \\
\text { hidráulicos }\end{array}$ & 19 anos & 24 \\
\hline I & Arquitetura & 3 & Projetos de Arquitetura & 19 anos & 3 \\
\hline
\end{tabular}

\begin{tabular}{|c|c|c|c|c|c|}
\hline Empresa & \begin{tabular}{|c|}
$\begin{array}{c}\text { Formação } \\
\text { do(s) } \\
\text { Titulares (s) }\end{array}$ \\
\end{tabular} & \begin{tabular}{|c|}
$\begin{array}{c}\text { Número de } \\
\text { Colaboradore } \\
\text { s Fixos }\end{array}$ \\
\end{tabular} & $\begin{array}{l}\text { Tipologia de projetos } \\
\text { desenvolvidos }\end{array}$ & $\begin{array}{l}\text { Tempo de } \\
\text { Existência }\end{array}$ & $\begin{array}{c}\text { Número de } \\
\text { Colaboradores } \\
\text { Especialistas } \\
\end{array}$ \\
\hline$J$ & $\begin{array}{c}\text { Engenharia e } \\
\text { Arquitetura }\end{array}$ & 4 & $\begin{array}{c}\text { Projetos, consultoria, assessoria em } \\
\text { esquadrias de alumínio }\end{array}$ & 5 anos & 4 \\
\hline K & $\begin{array}{l}\text { Engenharia } \\
\text { Civil e } \\
\text { Elétrica }\end{array}$ & 6 & $\begin{array}{c}\text { Projetos de instalações prediais e } \\
\text { estruturais }\end{array}$ & 3 anos & 3 \\
\hline L & $\begin{array}{c}\text { Engenharia } \\
\text { Civil }\end{array}$ & 5 & $\begin{array}{l}\text { Projetos estruturais em concreto } \\
\text { armado e protendido, pré-moldados } \\
\text { e alvenaria estrutural }\end{array}$ & 10 anos & 4 \\
\hline M & $\begin{array}{l}\text { Engenharia } \\
\text { Elétrica, } \\
\text { Mecânica e } \\
\text { Civil, } \\
\text { Arquitetura }\end{array}$ & 13 & $\begin{array}{l}\text { Projetos de tratamento acústico, } \\
\text { assessoria, consultoria, laudos, } \\
\text { medições de nível de ruído e } \\
\text { vibratório }\end{array}$ & 35 anos & 10 \\
\hline$N$ & Arquitetura & 2 & $\begin{array}{l}\text { Projetos de arquitetura para } \\
\text { edificações residenciais, comerciais } \\
\text { e industriais, coordenação de } \\
\text { projetos e projetos para interiores }\end{array}$ & 3 meses & 2 \\
\hline 0 & Arquitetura & 3 & $\begin{array}{l}\text { Projetos de arquitetura e } \\
\text { acompanhamento de obras }\end{array}$ & 15 anos & 3 \\
\hline$P$ & Arquitetura & 6 & $\begin{array}{l}\text { Projetos de arquitetura, incluindo } \\
\text { fiscalização de obras, quando de } \\
\text { autoria do escritório }\end{array}$ & 7 anos & 6 \\
\hline
\end{tabular}


Quanto à continuidade no programa, as empresas "C","F","H","l"," "L" e "P" não permaneceram até a sua conclusão. Os motivos das saídas são divergentes. As Empresas "I" e "F", embora tenham participado de praticamente todas as reuniões, não realizaram as atividades solicitadas e receberam em suas empresas os pesquisadores no máximo duas vezes, impossibilitando, dessa forma, o acompanhamento dos trabalhos.

A Empresa "H" deixou o programa logo após o desenvolvimento do primeiro módulo (planejamento estratégico e estrutura organizacional), sob a alegação de carga excessiva de trabalho, o que a impossibilitaria na continuidade de sua participação. Já a Empresa "C" desistiu do programa porque fundiu-se a uma outra empresa de projeto de arquitetura, que não participava do grupo, inviabilizando, dessa forma, a continuidade do trabalho. Quanto as Empresas "L" e "P", participantes do segundo grupo, assim como a Empresa " $\mathrm{H}$ ", alegaram indisponibilidade de tempo para continuidade no programa, em função da alta demanda de trabalho na ocasião.

Quando questionadas sobre os motivos que as levaram a participar do programa, de forma geral, as empresas apontaram, dentre os diversos fatores, a necessidade de melhor atender seus clientes, de ampliar a empresa organizadamente, reorganizar e otimizar a atividade projetual e obter conhecimentos para aplicação de práticas de gestão eficazes e eficientes.

\subsection{Sistematização do Trabalho durante a Pesquisa-Ação}

Tanto no PDGEP 1 quanto no PDEGEP 2, a rotina do programa era sistematizada através da realização de um diagnóstico com o objetivo de conhecer as práticas usuais de gestão das empresas, reuniões mensais com a participação de todos os participantes do grupo e visitas às empresas.

Conforme a Figura 3.1, a implementação do modelo deu-se na seguinte seqüência: Planejamento Estratégico e Estrutura Organizacional; Processo de Projeto; Gestão Financeira; Recursos Humanos; Comercial e Marketing; Sistema de Informação; 
Serviços Agregados ao Projeto e Gestão da Qualidade. A partir do módulo Planejamento Estratégico e Estrutura Organizacional, a escolha da ordem de implementação dos módulos aconteceu de forma coletiva, ou seja, através de consenso entre os pesquisadores.

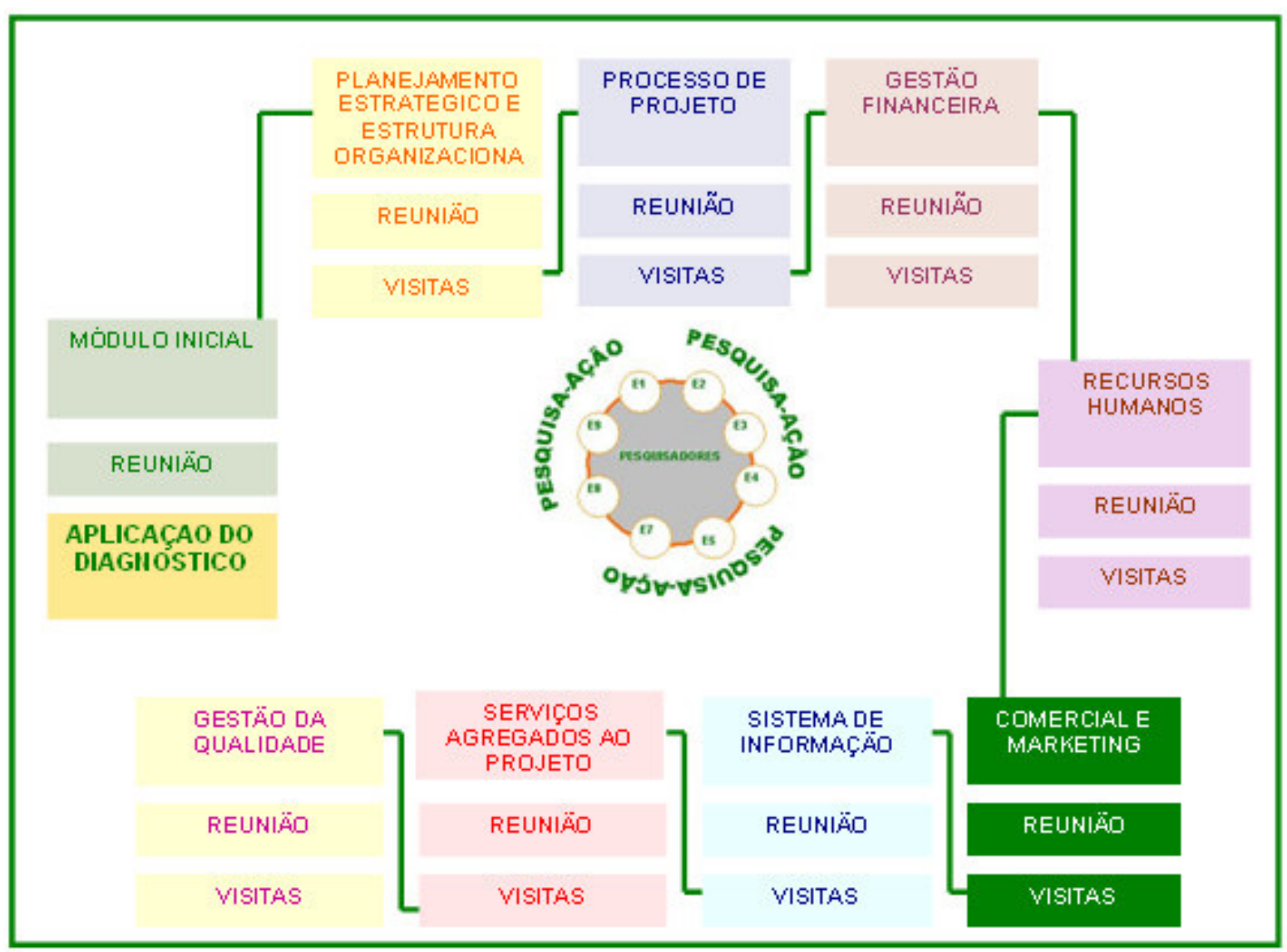

Figura 3.1 - Sequência da trabalho de trabalho do PDGEP 1

Comparando as Figuras 3.1 e 3.2, fica claro que a diferença entre os métodos de trabalho do PDGEP 1 e PDGEP 2 ocorreu na realização dos diagnósticos e na sequência de implementação dos módulos. Diferentemente do PDGEP 1, durante o PDGEP 2 os diagnósticos foram aplicados por módulo de trabalho, ou seja, antes de cada reunião mensal. As empresas recebiam um questionário contendo questões específicas relacionadas ao elemento de gestão a ser trabalhado no período e, após a reunião, tinham a oportunidade de avaliar as suas respostas e, se fosse o caso, respondê-las novamente.

A aplicação dos questionários para realização do diagnóstico de uma só vez e no início do programa, extensivo a todos os elementos de gestão do modelo, conforme realizado no PDGEP 1, dificultou a análise por parte dos pesquisadores quanto às 
reais práticas de gestão das empresas. As respostas obtidas, em sua maior parte, demonstravam total desconhecimento em relação aos tópicos questionados e, portanto, as respostas não conduziam ao real diagnóstico da situação das empresas. A mudança quanto à sistematização da aplicação dos diagnósticos permitiu aos pesquisadores a obtenção de respostas mais precisas, as quais possibilitaram, de fato, maior conhecimento das características gerais das empresas e de suas práticas gerenciais, antes da implementação do referido modelo.

Ainda sobre a diferença do método de trabalho empregado no PDGEP 1 e no PDGEP 2, a mudança na seqüência de implementação dos módulos ocorreu porque as seqüências de trabalhos, tanto no primeiro quanto no segundo grupo, eram decididas coletivamente (pesquisadores e empresas), sendo que as decisões eram baseadas nas expectativas e na necessidade de organização das empresas.

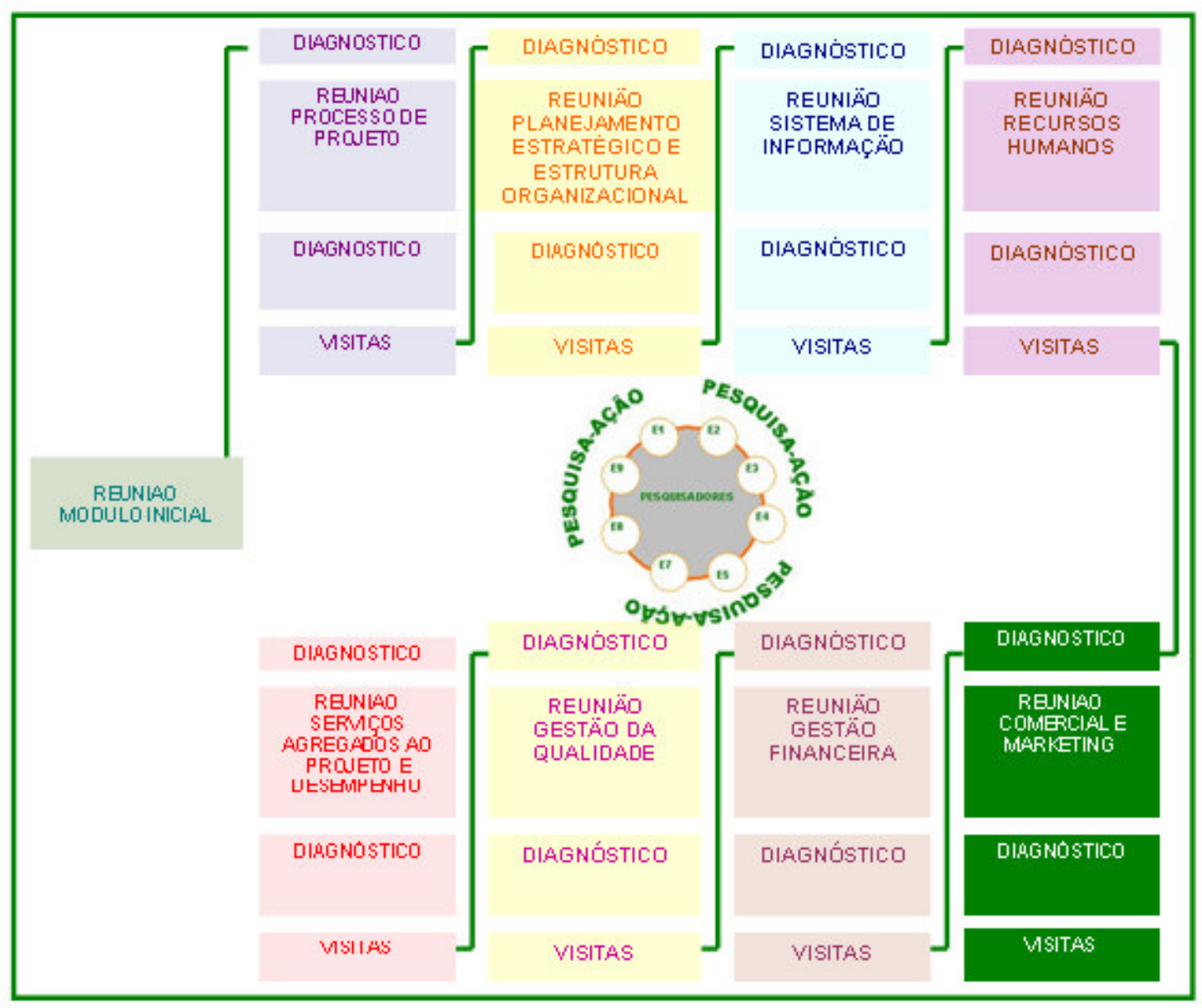

Figura 3.2 - Sequência da trabalho de trabalho do PDGEP 2 
As reuniões coletivas tinham como objetivo a apresentação de cada um dos elementos componentes do modelo de gestão separadamente, além da proposição de tarefas referentes ao elemento em discussão na ocasião, tarefas essas a serem desenvolvidas no decorrer do mês pelas empresas, de maneira individual. Assim, parte do tempo das reuniões mensais era utilizado para promover a interação e a troca de experiências entre as empresas e os pesquisadores dos grupos, através de tarefas, discussões ou dinâmicas a serem desenvolvidas coletivamente.

Como já apresentado no item 1.3 - Método de Pesquisa, as visitas às empresas do Grupo 1 eram realizadas mensalmente, enquanto que no Grupo 2 eram bimestrais, e objetivavam, em principio, a coleta de dados para as pesquisas. Contudo, no decorrer do programa, verificou-se que as visitas passaram a ser também elemento de motivação para as empresas no desenvolvimento das tarefas e das atividades inerentes à implementação do modelo.

Com base no método de pesquisa-ação crítica como um processo de reflexão-ação coletivo, conforme mencionado no item 1.3 - Método de Pesquisa, durante o trabalho do PDGEP, houve diversos momentos de reflexão com o objetivo de reformular as estratégias de atuação e ações dos pesquisadores junto aos grupos de empresas, dentre as quais destacam-se: a forma de aplicação dos diagnósticos; a ordem de implementação dos módulos; a sistematização das visitas às empresas quanto ao uso de ferramentas para a coleta de dados; e as mudanças quanto à estrutura das reuniões mensais, no sentido de propor, de fato, a interação e troca de experiências entre as empresas.

\subsection{Programa de Desenvolvimento Gerencial para Empresas de Projeto: Etapa da Implementação do Modelo de Gestão}

O trabalho de pesquisa foi dividido em oito módulos (inicial, planejamento estratégico, processo de projeto, sistema de informação, gestão de recursos humanos, gestão comercial e marketing, gestão financeira, serviços agregados ao projeto, desempenho e gestão da qualidade), e a implementação do modelo deu-se 
através da realização de diagnóstico inicial, reuniões coletivas para apresentação de cada um dos elementos de gestão e visitas às empresas.

Como já colocado anteriormente, o diagnóstico preliminar para o PDGEP 1 foi realizado no início dos trabalhos e extensivo a todos os elementos do modelo, enquanto que no PDGEP 2 o diagnóstico deu-se gradualmente ao longo do programa, através da aplicação de um questionário com questões relacionadas basicamente aos pontos a serem trabalhados durante o módulo, e outros que poderiam dar suporte ao seu desenvolvimento.

No entanto, verificou-se, ao longo de programa, que o conhecimento prévio das práticas de gestão das empresas antes do PDGEP 1 e PDGEP 2 não se restringiram à análise dos diagnósticos iniciais, uma vez que as discussões durante as reuniões coletivas e visitas às empresas possibilitavam aos pesquisadores a confirmação ou não das respostas colocadas nos questionários, e a ampliação do conhecimento das reais práticas gerenciais das empresas, bem como de suas dificuldades e limitações no desenvolvimento das tarefas e implementação efetiva do programa.

Nesse sentido, as impressões coletadas durante as reuniões e visitas às empresas, tanto durante O PDGEP 1 quanto durante O PDGEP 2, complementaram as informações para formulação de um real diagnóstico das empresas, ilustradas na Tabela 3.3, as quais forneceram, de fato, um "retrato" mais preciso e fiel das empresas, contribuindo para o direcionamento das ações tanto durante o PDGEP 1 quanto durante o PDGEP 2. 


\begin{tabular}{|c|c|}
\hline $\begin{array}{c}\text { Elemento } \\
\text { de } \\
\text { Gestão }\end{array}$ & Práticas de gestão: diagnóstico inicial + impressões coletadas nas reuniões e visitas \\
\hline 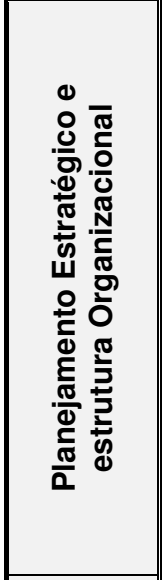 & $\begin{array}{l}\text { - A prática do planejamento estratégico não é sistemática. } \\
\text { - Não realizam autoanálise quanto aos seus pontos fracos e fortes, nem análises } \\
\text { - As empresadosicas. } \\
\text { seus clientes, dificultando, dessa forma, o estabelecimento de estratégias quanto a } \\
\text { identificação de novos clientes, potencialização do relacionamento com os atuais, } \\
\text { precificação, definição do corpo técnico da empresa, vendas e contratações. } \\
\text { O organograma de algumas empresas normalmente não condizem com a sua } \\
\text { realidade, nem representam a real disposição de responsabilidades e de autoridade. } \\
\text { - Não entendem a real importância para a definição de uma estrutura organizacional } \\
\text { compatível com a estratégia da empresa e suas características gerais. } \\
\text { Em decorrência do desconhecimento do montante de atividades que desenvolvem, e } \\
\text { por não estarem detalhadas de forma adequada, verifica-se nas empresas a } \\
\text { centralização de responsabilidades. }\end{array}$ \\
\hline 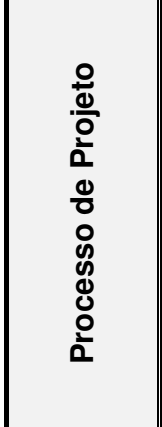 & $\begin{array}{l}\text { - Não possuem o fluxo de trabalho estabelecido para os diversos processos da empresa, } \\
\text { - Nanto os técnicos quanto os administrativos. } \\
\text { - Não possuem ferramentas para o planejamento e o controle do processo de projeto. } \\
\text { analisam as interfaces com os trabalhos em desenvolvimento na empresa. } \\
\text { - Não praticam a retroalimentação do processo de projeto (tecnologia empregada, } \\
\text { eficácia das soluções projetuais, produtividade, retorno financeiro do projeto) através } \\
\text { de indicadores. } \\
\text { - Não costumam analisar criticamente os processos e as ferramentas utilizadas e, a } \\
\text { partir daí, estabelecer a rotina de retroalimentação e aperfeiçoamento contínuo. }\end{array}$ \\
\hline 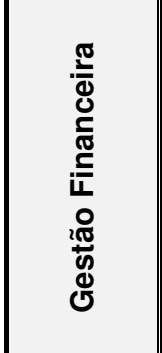 & $\begin{array}{l}\text { - Desconhecimento dos métodos eficazes para a gestão financeira de uma pequena } \\
\text { - } \text { - Desconpresa. } \\
\text { financeira que levem à obtenção de informações relevantes para empresa. } \\
\text { - Algumas empresas dispunham de ferramentas ineficazes ou até mesmo impróprias } \\
\text { para a gestão financeira. } \\
\text { - Desorganização das despesas e receitas das empresas. } \\
\text { - Descontrole sobre os resultados financeiros de cada um dos projetos. }\end{array}$ \\
\hline 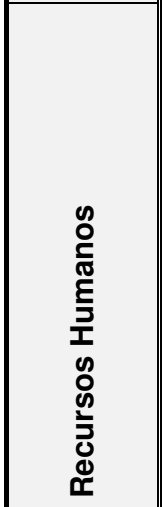 & $\begin{array}{l}\text { - As empresas não possuem processo de contratação de novos colaboradores } \\
\text { sistematizado (seleção, recrutamento e contratação). } \\
\text { - As empresas não têm organizadas as funções, seus cargos e salários. } \\
\text { - Não são estabelecidos os perfis (competências e habilidades) dos profissionais } \\
\text { técnicos e administrativos das empresas. } \\
\text { A análise e planejamento que direcionam a necessidade de contratação e/ou } \\
\text { aperfeiçoamento de colaboradores não é sistematizada. } \\
\text { As empresas entendem as gratificações financeiras como única forma de } \\
\text { reconhecimento e apreço sobre as realizações profissionais. } \\
\text { - Não existe nas empresas nenhuma política relativa a remuneração. } \\
\text { - Não existe metodologia estabelecida para a avaliação dos colaboradores, e nem plano } \\
\text { de desenvolvimento profissional. }\end{array}$ \\
\hline & \\
\hline
\end{tabular}


Tabela 3.3: Práticas de gestão das Empresas antes da participação no PDGEP 1 e PDGEP

\begin{tabular}{|c|c|}
\hline $\begin{array}{c}\text { Elemento } \\
\text { de }\end{array}$ & Práticas de gestão: diagnóstico inicial + impressões coletadas nas reuniões e visitas \\
\hline 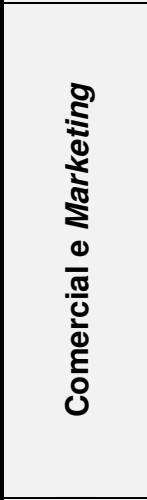 & $\begin{array}{l}\text { - Negligência nas análises necessárias para a elaboração das propostas técnico- } \\
\text { - Nemerciais. } \\
\text { dos seus clientes não são organizadas. } \\
\text { - O escopo de trabalho não é definido adequadamente nas propostas técnicas. } \\
\text { - Trabalham de forma reativa, ou seja, sob demanda. Não realizam análises e não } \\
\text { sistematizam ações que os levem a novos mercados e clientes. } \\
\text { - Normalmente, mesmo em projetos de maior porte ou complexidade, não fazem uso de } \\
\text { instrumento jurídico que Ihes assegure direitos, deveres e limites do trabalho } \\
\text { contratado. } \\
\text { Não fazem uso de controles e indicadores que indiquem para a empresa a adequada } \\
\text { precificação. }\end{array}$ \\
\hline 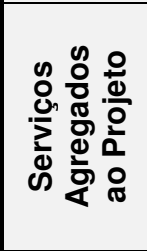 & $\begin{array}{l}\text { - Falta sistematização quanto à entrega de seus projetos, visitas à obra durante a } \\
\text { execução e avaliação pós-ocupação. } \\
\text { - Organização das informações provenientes da comunicação junto ao cliente e/ou } \\
\text { usuários do projeto. } \\
\text { Desconhecem os benefícios da adoção de indicadores como ferramenta para } \\
\text { retroalimentação do processo de projeto. }\end{array}$ \\
\hline 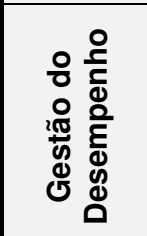 & $\begin{array}{l}\text { - A maior parte das empresas não faz uso de indicadores para acompanhamento do } \\
\text { processo de projeto, nem das rotinas gerenciais da empresa como um todo. } \\
\text { As empresas que fazem uso de indicadores para acompanhamento do processo de } \\
\text { projeto e gestão da empresa, não utilizam adequadamente as informações } \\
\text { provenientes desses indicadores para a tomada de decisão. }\end{array}$ \\
\hline 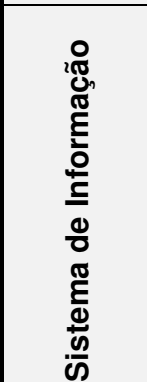 & $\begin{array}{l}\text { - Desconhecem o fluxo de informações referentes aos diversos processos da empresa } \\
\text { (técnicos e administrativos). } \\
\text { Desconhecem métodos e ferramentas para sistematização da captação, organização e } \\
\text { disponibilização da informação, tanto para o processo de projeto quanto para os } \\
\text { processos gerenciais. } \\
\text { - Não têm sistematizada a transformação da comunicação, principalmente a verbal, em } \\
\text { dados para o projeto. } \\
\text { Subutilização de ferramentas para a gestão da informação durante o processo de } \\
\text { projeto. }\end{array}$ \\
\hline
\end{tabular}

A Tabela 3.3 sintetiza as práticas de gestão das empresas de projeto participantes do PDGEP 1 e PDGEP 2 antes da implementação do modelo de gestão. Tais impressões foram coletadas através da aplicação de questionários, durante as reuniões coletivas e nas visitas às empresas.

Quanto à generalização das impressões contidas na Tabela 3.3, quando analisados os questionários e a postura das empresas, verificou-se semelhança entre as deficiências e práticas relacionadas à gestão. Nesse sentido, entendeu-se que não havia necessidade de desatacar na tabela as empresas e nem os grupos dos quais participaram. 
Apesar de a Tabela 3.3 mostrar apenas as deficiências, nem todas as empresas participantes dos programas eram deficientes do ponto de vista da gestão. As boas práticas, apesar de escassas, não foram destacadas porque, para o trabalho de desenvolvimento gerencial, são consideradas como elementos que agregam valor, possibilitando, dessa forma, maior desempenho para as empresas. Por outro lado, do ponto de vista da pesquisa e dos objetivos deste trabalho, são as deficiências que remetem às análises e considerações.

De forma geral, as principais deficiências diagnosticadas nas empresas referem-se principalmente à concentração de responsabilidades na figura do profissional titular da empresa e ao desconhecimento das práticas e técnicas de gerenciamento e dos benefícios trazidos pela sua aplicação.

Outro aspecto interessante diz respeito a falta de visão sistêmica dos titulares e colaboradores em relação às pequenas empresas de projeto. Essa foi uma deficiência diagnosticada logo no início de ambos os programas em praticamente todas as empresas e, ao longo do PDGEP 1 e PDGEP 2, foi um dos principais fatores causadores de dificuldades para as empresas na implementação do modelo e posterior desenvolvimento das tarefas.

Não foi realizado diagnóstico referente ao elemento gestão da qualidade porque nenhuma das empresas participantes do PDGEP 1 e 2 tinham sistema de gestão da qualidade implementado. Apesar de algumas empresas utilizarem ferramentas para controle do processo de projeto, a sua aplicação não configurava em sistema de gestão da qualidade em funcionamento.

A Tabela 3.4 demonstra as atividades desenvolvidas durante o PDGEP 1 e PDGEP 2 na implementação do modelo de gestão proposto por Oliveira (2005). Cada uma das reuniões foi estruturada de forma a conduzir a discussão do elemento de gestão a ser implementado, levando-se em consideração as características gerais das empresas de projeto e suas necessidades gerenciais. As tarefas foram propostas com objetivo de facilitar e direcionar o trabalho de implementação de cada um dos elementos de gestão do referido modelo. 
Tabela 3.4: Resumo das atividades desenvolvidas durante o PDGEP 1 e PDGEP 2

\begin{tabular}{|c|c|c|}
\hline Tópico & Tópicos discutidos nas reuniões & Tarefas solicitadas \\
\hline 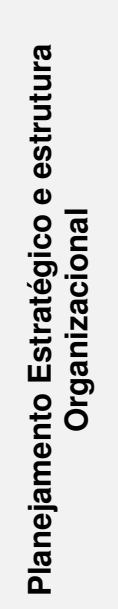 & $\begin{array}{l}\text { - Conceitos relacionados a gestão } \\
\text { empresarial. } \\
\text { O papel da empresa de projeto no } \\
\text { setor da construção civil. } \\
\text { A importância da organização da } \\
\text { empresa na definição de } \\
\text { responsabilidades e de autoridade. }\end{array}$ & $\begin{array}{l}\text { 1) A definição da missão da empresa (PDGEP 1). } \\
\text { 2) Piloto para o planejamento estratégico (análise } \\
\text { interna, análise externa, estabelecimento de } \\
\text { objetivos, metas e indicadores) (PDGEP } 1 \text { e } \\
\text { PDGEP 2). } \\
\text { 3) Esboço do organograma da empresa levando } \\
\text { em consideração a divisão de } \\
\text { responsabilidades e autoridade (PDGEP } 1 \text { e } \\
\text { PDGEP 2). } \\
\text { Definição e delineamento dos } \\
\text { produtos/serviços oferecidos pelas } \\
\text { empresas aos seus clientes (características } \\
\text { técnicas, perfil dos profissionais responsáveis, } \\
\text { mercado, preço e participação no faturamento) } \\
\text { (PDGEP 2). }\end{array}$ \\
\hline \multirow[t]{2}{*}{ 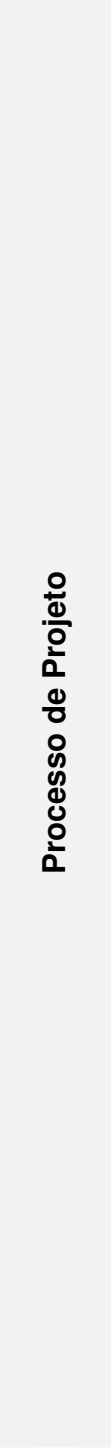 } & $\begin{array}{l}\text { - } \begin{array}{l}\text { Expectativas dos clientes quanto ao } \\
\text { desenvolvimento de projetos. }\end{array} \\
\text { Importância do processo de projeto } \\
\text { para a empresa do ponto de vista } \\
\text { estratégico. } \\
\text { - Gestão da qualidade do processo } \\
\text { de projeto. } \\
\text { Importância da gestão do processo } \\
\text { de projeto, análise da complexidade } \\
\text { do projeto, planejamento (tempo, } \\
\text { pessoas, tecnologia, finanças), } \\
\text { controle (tempo, produtividade, } \\
\text { retrabalho, finanças) } \\
\text { retroalimentação (tecnologia } \\
\text { empregada, eficácia das soluções } \\
\text { projetuais, produtividade, retorno } \\
\text { financeiro do projeto). } \\
\text { Técnicas e Inovações associadas } \\
\text { ao processo de projeto: engenharia } \\
\text { simultânea; projeto para produção; } \\
\text { banco de tecnologia construtiva e } \\
\text { avaliação pós-ocupação. }\end{array}$ & $\begin{array}{l}\text { - Oesenho de um dos processos da empresa } \\
\text { (administrativo ou técnico) através de um } \\
\text { macrofluxo e a identificação das ferramentas } \\
\text { utilizadas (PDGEP 1 e PDGEP 2). } \\
\text { 2) Planejamento de um dos projetos da empresa } \\
\text { em fase inicial, abrangendo os seguintes } \\
\text { aspectos (PDGEP 2): } \\
\text { - Tempo para realização de cada uma das } \\
\text { etapas. } \\
\text { Emprego dos recursos. } \\
\text { - Comunicação. } \\
\text { - Contramento das informações. } \\
\text { - Controle do planejamento. } \\
\text { - Definição de Indicadores de desempenho. }\end{array}$ \\
\hline & Con & \\
\hline
\end{tabular}


Tabela 3.4: Resumo das atividades desenvolvidas durante o PDGEP 1 e PDGEP 2

\begin{tabular}{|c|c|c|}
\hline Tópico & Tópicos discutidos nas reuniões & Tarefas solicitadas \\
\hline 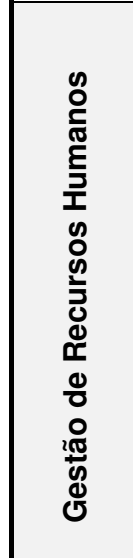 & 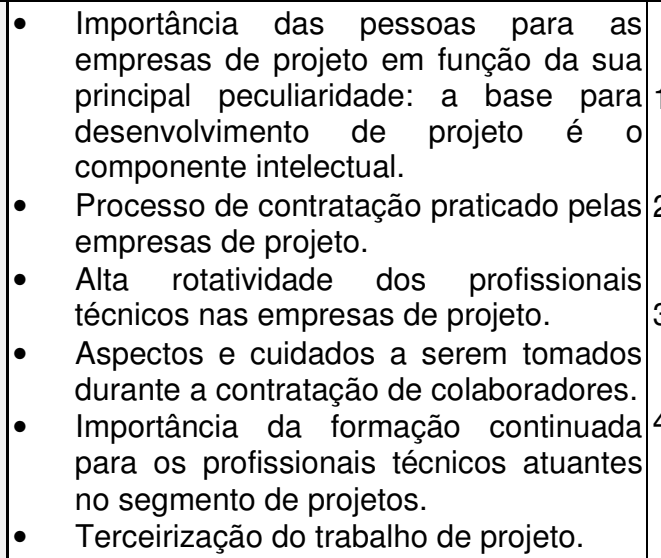 & $\begin{array}{l}\text { 1) Plano de treinamento para cada um dos cargos da } \\
\text { empresa no horizonte de um ano (PDGEP } 1 \text { e } \\
\text { PDGEP 2). } \\
\text { 2) Elaboração de um roteiro para a contratação de } \\
\text { colaboradores para três cargos, pelo menos. } \\
\text { (PDGEP } 1 \text { e PDGEP 2). } \\
\text { 3) A elaboração de diretrizes (regras) para a empresa } \\
\text { que assume a posição de contratante na } \\
\text { terceirização (PDGEP } 1 \text { e PDGEP 2). } \\
\text { 4) A elaboração de diretrizes para o caso de a } \\
\text { empresa assumir o papel de contratada na } \\
\text { terceirização (PDGEP } 1 \text { e PDGEP 2). }\end{array}$ \\
\hline 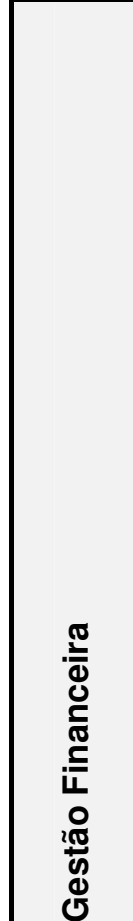 & $\begin{array}{l}\text { - Parâmetros para a tomada de } \\
\text { decisão na formação dos preços de } \\
\text { projeto. } \\
\text { Características gerais que deve } \\
\text { possuir um sistema de gestão } \\
\text { financeira: fornecimento de } \\
\text { informações sobre os resultados } \\
\text { obtidos e apresentação de relatórios } \\
\text { de forma a subsidiar o controle e o } \\
\text { planejamento da empresa. } \\
\text { Classificação das despesas e } \\
\text { receitas e sua importância para a } \\
\text { estruturação do sistema financeiro e } \\
\text { posterior controle. } \\
\text { Controles básicos que uma empresa } \\
\text { de projeto deve possuir: controle de } \\
\text { caixa; controle de bancos; controle } \\
\text { de contas a receber e controle de } \\
\text { contas a pagar. } \\
\text { A importância do controle referente } \\
\text { às despesas e receitas referentes } \\
\text { aos projetos individualmente }\end{array}$ & $\begin{array}{l}\text { 1) Elaboração de uma planilha contendo a } \\
\text { classificação de todas as possíveis } \\
\text { despesas e receitas da empresa (PDGEP } 1 \text { e } \\
\text { PDGEP 2). } \\
\text { 2) Também foi solicitado para que as empresas } \\
\text { analisassem se a melhor forma de controlar } \\
\text { despesas e receitas dos projetos seria o } \\
\text { controle por cliente ou por empreendimento, } \\
\text { elaborando uma planilha demonstrando } \\
\text { essa classificação (PDGEP 1 e PDGEP 2). }\end{array}$ \\
\hline
\end{tabular}


Tabela 3.4: Resumo das atividades desenvolvidas durante o PDGEP 1 e PDGEP 2

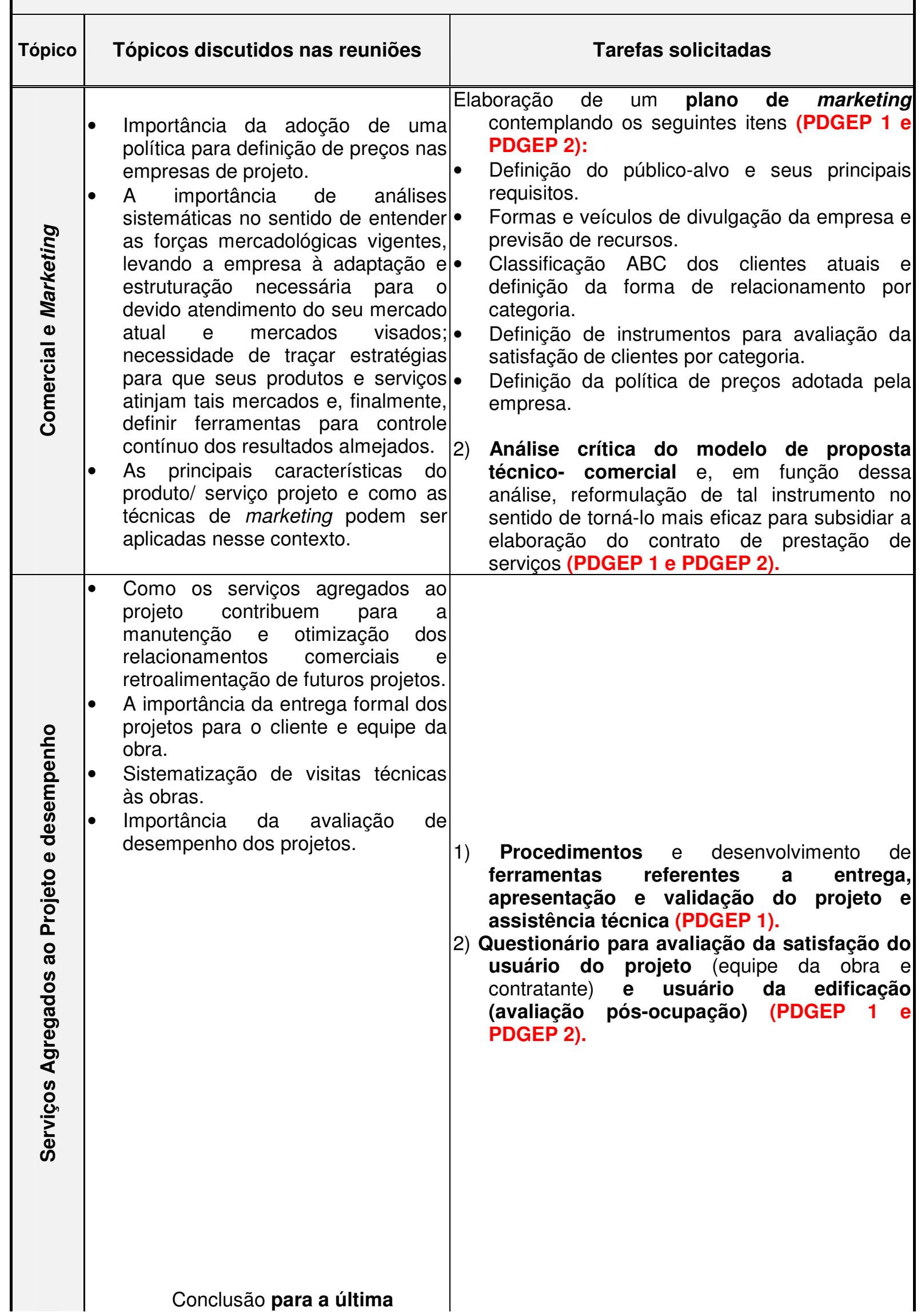


Tabela 3.4: Resumo das atividades desenvolvidas durante o PDGEP 1 e PDGEP 2

\begin{tabular}{|c|c|c|}
\hline Tópico & Tópicos discutidos nas reuniões & Tarefas solicitadas \\
\hline 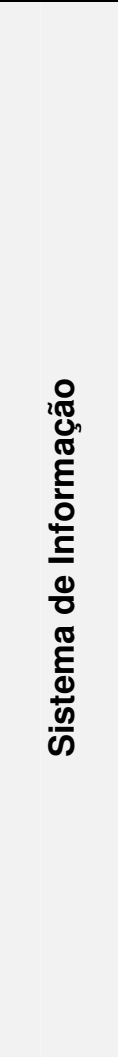 & $\begin{array}{l}\text { - Papel e importância do sistema de } \\
\text { informação como conector entre } \\
\text { todos os outros subsistemas de } \\
\text { gestão empresarial. } \\
\text { - Predominância da comunicação } \\
\text { informal nas empresas de projeto. } \\
\text { - aumento da complexidade da } \\
\text { gestão da informação na empresa } \\
\text { de projeto é proporcional ao seu } \\
\text { número de projetos em } \\
\text { desenvolvimento. } \\
\text { - Escassez de sistemas de gestão da } \\
\text { informação para pequenas } \\
\text { empresas de projeto. } \\
\text { Vantagens sobre o uso da } \\
\text { tecnologia da informação durante o } \\
\text { processo de projeto. }\end{array}$ & $\begin{array}{l}\text { 1) Desenvolvimento de ferramentas para controle } \\
\text { da informação durante o processo de projeto } \\
\text { (PDGEP 1): } \\
\text { - Listas de verificação do processo de projeto. } \\
\text { - Ferramentas para captação, organização e } \\
\text { disponibilização das informações durante o } \\
\text { processo, principalmente as verbais (telefone, } \\
\text { reuniões, etc.). } \\
\text { 2) Mapeamento do fluxo de informações relativo } \\
\text { ao processo de projeto, através do método } \\
\text { proposto por Turban; MacLean; Wetherbe } \\
\text { (2004) denominado Modelo de planejamento } \\
\text { para análise de requisitos da informação } \\
\text { (PDGEP 2): } \\
\text { Em função do mapeamento do processo de } \\
\text { projeto, identificar todas as atividades inerentes } \\
\text { ao processo. } \\
\text { Definir a avaliar a necessidade de informações } \\
\text { em cada uma das etapas. } \\
\text { Classificar as informações a partir da sua } \\
\text { categorização (especialidade, procedência, } \\
\text { relevância, etc.). } \\
\text { A partir desse mapeamento, definir } \\
\text { procedimentos e/ou ferramentas para gestão } \\
\text { das informações (captação, organização e } \\
\text { disponibilização) referentes ao processo de projeto. }\end{array}$ \\
\hline
\end{tabular}

Se comparado às tarefas solicitadas, verifica-se, em alguns casos, diferenças ou complementações de tarefas do PDGEP 1 para o PDGEP 2, a exemplo dos módulos estrutura organizacional e planejamento estratégico, processo de projeto, serviços agregados e sistema de informação.

Partindo dos princípios da pesquisa-ação crítica, citados no Item 1.4 - Metodologia da Pesquisa, tais alterações ocorreram porque constatou-se demasiada dificuldade, por parte das empresas, no desenvolvimento de algumas tarefas durante o PDGEP.

Em contrapartida, também houve situações nas quais as empresas desenvolveram as tarefas com muita facilidade, e em outras situações perceberam-se lacunas na sua proposição, impossibilitando, dessa forma, a plena implementação do módulo de gestão. 
A finalização do trabalho de pesquisa-ação ocorreu através da aplicação de um questionário, cujo objetivo era compreender o comportamento das empresas após o programa, e postura quanto à continuidade do desenvolvimento gerencial.

Das empresas participantes do PDGEP 1, responderam ao questionário as empresas "A", "B", "E", "G" e "l". Quanto ao PDGEP 2, responderam as empresas "J", "K" "M" e "N".

O questionário foi dividido em cinco seções. A primeira referia-se à estrutura atual da empresa e serviços fornecidos. Na segunda seção, as questões enfocavam a impressão das empresas quanto a metodologia de trabalho utilizada nos grupos (aspectos negativos e positivos apontados pelas empresas, divisão do trabalho através de módulos, sequência adotada, intervalo de tempo entre os módulos e estratégia utilizada pela empresa para a implementação do referido modelo).

A terceira seção continha questões cujos objetivos eram: confirmar quais tarefas tinham sido desenvolvidas em cada um dos módulos e entender se, ao aderirem aos programas, as expectativas das empresas tinham sido atendidas ou não.

A quarta seção referia-se à continuidade do desenvolvimento gerencial por parte da empresa de forma individual. Foram questionados aspectos relacionados a continuação de discussões e análises críticas gerenciais, uso e aperfeiçoamento de ferramentas desenvolvidas durante o programa.

Finalizando, a quinta seção referia-se à postura dos titulares frente aos problemas gerenciais e às mudanças percebidas pelas empresas após a participação nos programas.

\subsection{Análise da Aplicação do Modelo de Gestão: Reações das empresas na aplicação do modelo}

A análise referente à reação das empresas na aplicação do modelo objetiva avaliar o comportamento das empresas no grupo, as estratégias adotadas quanto a 
sistematização das ações para implementação do modelo de gestão e dificuldades no desenvolvimento das tarefas.

De acordo com o Item 1.2 - Justificativa, a implementação do modelo através de grupos de trabalho dirigido possibilita a constante troca de experiências, ampla discussão coletiva de problemas comuns e sistematização nas ações de implementação do referido modelo.

Nesse sentido, durante o PDGEP 1, percebeu-se resistência na exposição das experiências por parte de algumas empresas. Essas empresas tinham receio de que, através da exposição, suas boas práticas de gestão, assim como os procedimentos e ferramentas desenvolvidos durante o programa, pudessem ser copiados por outras empresas, principalmente pelos concorrentes diretos, comprometendo, dessa forma, suas vantagens competitivas.

Contudo, a maior parte das empresas apreciou a oportunidade de discutir problemas comuns e, portanto, não teve receio de se expor durante o programa, submetendose às críticas e sugestões por parte dos pesquisadores e das outras empresas.

Com o decorrer do tempo, as empresas que se mostraram reticentes no início, e que continuaram no grupo, perceberam que os objetivos do trabalho de desenvolvimento gerencial extrapolavam a possibilidade de se copiar procedimentos e ferramentas. $O$ trabalho em grupo possibilitava, além do autoconhecimento, a evolução da postura crítica em relação às questões gerenciais, aquisição de conhecimento e amadurecimento empresarial.

Com o objetivo de evitar a resistência inicial sentida no PDGEP 1 , solicitou-se às empresas do PDGEP 2, logo no seu início, a formalização do compromisso de envolvimento com as atividades propostas através de um termo de responsabilidade, cuja finalidade era esclarecer seus objetivos e rotinas de trabalho, incluindo a exposição constante de experiências por parte das empresas.

Este termo também foi fundamental para os esclarecimentos necessários relativos aos objetivos essenciais do grupo, pois, apesar de tratar-se de um trabalho voluntário cujo propósito principal era a pesquisa, algumas empresas entendiam a atuação dos pesquisadores de forma similar à dos consultores. 
Nesse sentido, durante o PDGEP 1, houve situações nas quais algumas empresas tinham a expectativa de que os pesquisadores solucionassem seus problemas gerenciais de forma dirigida, tal como fariam consultores contratados. No entanto, esclareceu-se que a atuação dos pesquisares no contexto do programa estava voltada à proposição de estratégias e atividades para facilitar o desenvolvimento gerencial das empresas, através de discussões, exposições e análises críticas.

O desenvolvimento das tarefas e as formas pelas quais foram desenvolvidas pelas empresas podem ser observados nas Tabelas 3.5 e 3.6. Para a classificação do desenvolvimento das tarefas, foram levados em consideração os seguintes parâmetros: a realização total das tarefas (procedimentos e/ou ferramentas totalmente desenvolvidas e operacionalizadas), tarefas realizadas mas não operacionalizadas e tarefas não cumpridas. 


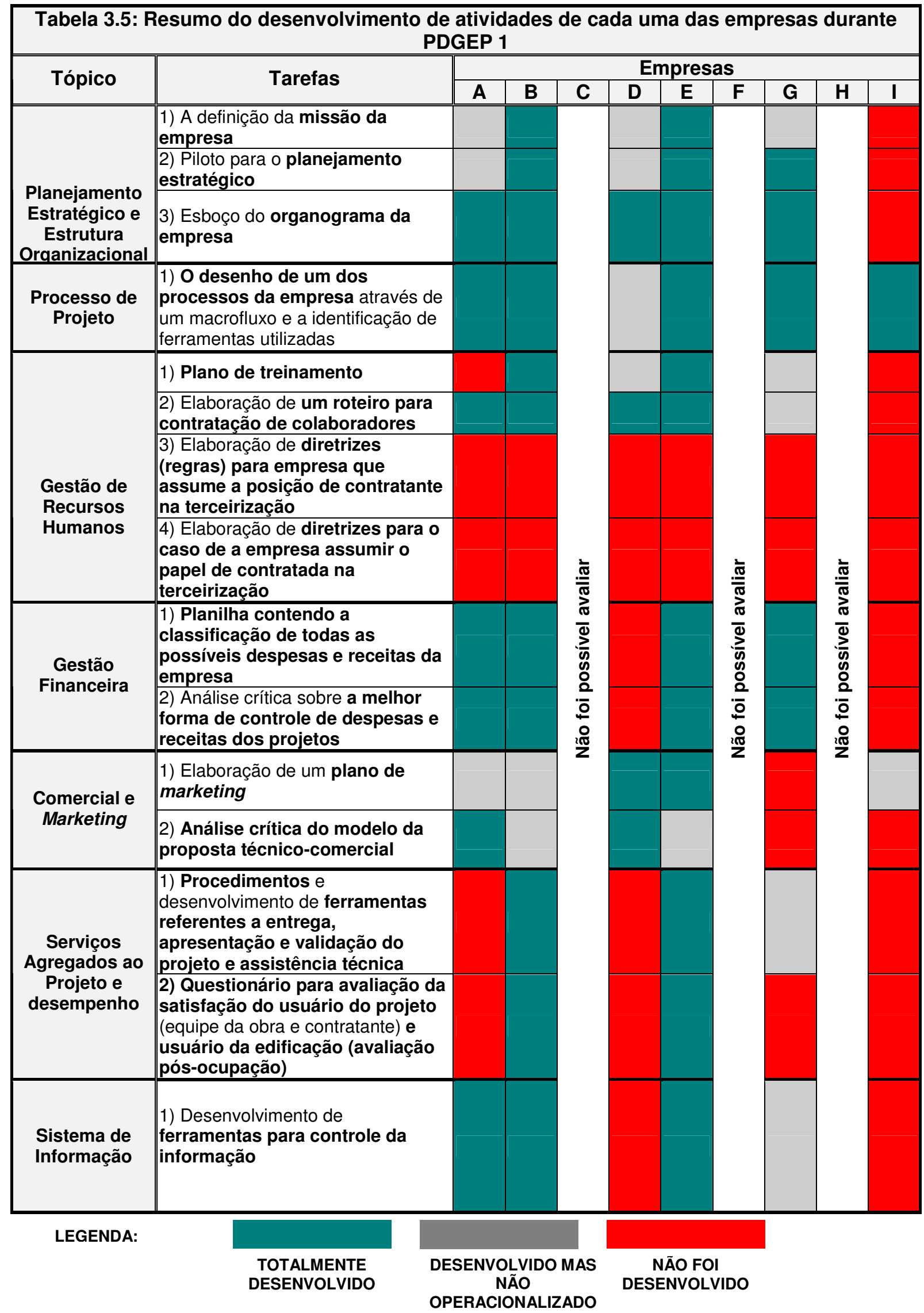


Tabela 3.6: Resumo do desenvolvimento de atividades de cada uma das empresas durante PDGEP 2

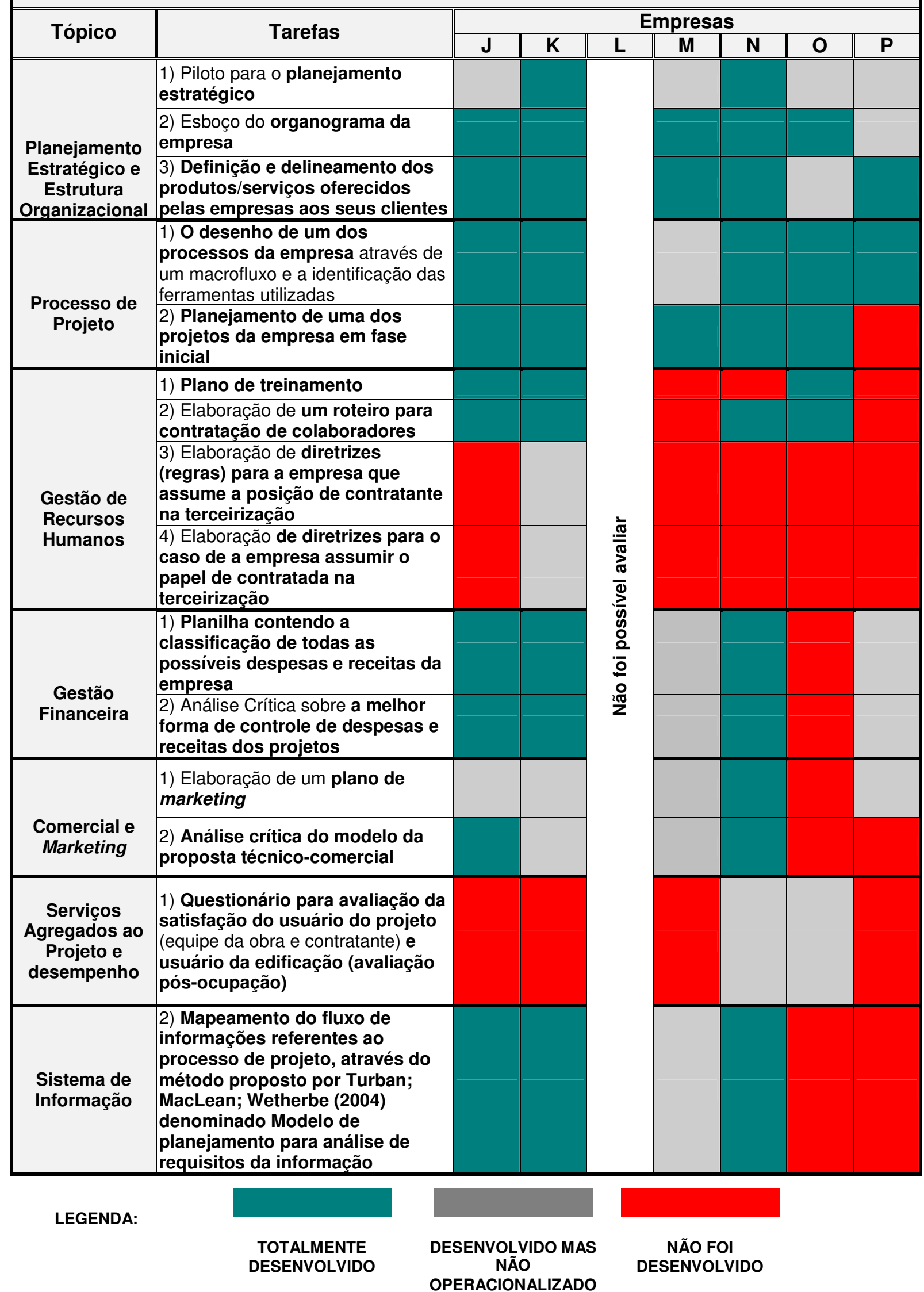


Através da análise das Tabelas 3.5 e 3.6, observa-se o resumo do desenvolvimento das atividades de cada uma das empresas. Percebe-se ainda que o modelo de gestão não foi plenamente implementado por nenhuma das empresas, uma vez que não desenvolveram todas as tarefas solicitadas.

Tanto no Grupo 1 quanto no Grupo 2, as tarefas solicitadas nos módulos iniciais planejamento estratégico e processo de projeto, foram plenamente desenvolvidas e implementadas por praticamente todas as empresas.

Uma vez que a organização do processo de projeto e desenvolvimento de ferramentas para controle era um dos principais anseios das empresas ao aderirem ao programa, percebeu-se que, mesmo após a finalização desse modulo, a maior parte das empresas continuaram trabalhando no desenvolvimento de procedimentos e ferramentas.

Quanto às tarefas relativas à gestão de recursos humanos, verificou-se grande empenho no desenvolvimento de ferramentas voltadas à contratação de pessoal e plano de desenvolvimento profissional. Essa tendência confirmou-se nas discussões dos PDGEP 1 e 2, quando as empresas trouxeram problemas relacionados à alta rotatividade de profissionais técnicos nas empresas de projeto, destacando como principal motivo as contratações equivocadas em função da inexistência de métodos e ferramentas para gestão de pessoas.

Constata-se que, por se tratarem de pequenas empresas, as possibilidades quanto ao desenvolvimento de pessoal são bastante limitadas, pois a formação de equipes competentes e harmoniosas leva anos de investimento no capital humano. Nesse sentido, foi fundamental para as empresas entenderem a complexidade e a importância do assunto e, em função de suas limitações gerais, desenvolverem ferramentas eficazes e adequadas, tais como roteiros simples de contratação e planos de capacitação coerentes com suas demandas e características específicas.

Ao contrário da especial atenção aplicada ao desenvolvimento de ferramentas e métodos para contratação e gestão de pessoas, as tarefas referentes à elaboração de diretrizes voltadas para a terceirização foram negligenciadas pelas empresas de ambos os grupos. 
Nota-se que a terceirização é uma realidade no segmento de projetos. No entanto, para a maior parte das empresas, há resistência em relação ao seu reconhecimento. Segundo testemunhos das empresas participantes do PDGEP 1, essas contratações são realizadas, em sua maior parte, sob sigilo e sem aplicação de controles adequados quanto ao escopo do trabalho e decisões quanto às soluções projetuais, principalmente aquelas relacionadas à definição de tecnologias e comunicação junto ao contratante, entre outros aspectos.

Uma vez que as tarefas relacionadas à terceirização de projetos não foram realizadas por nenhuma das empresas, confirma-se a postura dos profissionais em relação ao reconhecimento da terceirização como uma realidade que, se encarada de forma adequada, pode representar mais um passo no desenvolvimento do segmento de projetos, pois a terceirização em si não compromete o processo de projeto, e sim a falta de transparência nas contratações, acarretando negligências recorrentes no seu controle.

$\mathrm{Na}$ aplicação do questionário final, realizada após a participação nos programas, as perguntas referiam-se à ordem de implementação dos módulos, pertinência e nível de dificuldade das tarefas no sentido de possibilitar a implementação do modelo de gestão proposto e tempo disponibilizado para o seu desenvolvimento.

Quanto à ordem de implementação, a maior parte das empresas sugerem que se inicie pelo processo de projeto, sob o argumento de que esse é o principal processo da empresa de projeto, portanto, todos os outros processos gerenciais das empresas são influenciados diretamente por ele.

Com relação à pertinência das tarefas para a implementação do modelo, as respostas foram positivamente unânimes. No entanto, as empresas destacaram dificuldades no desenvolvimento das tarefas referentes ao módulo planejamento estratégico, tanto no PDGEP 1 quanto no PDGEP 2, assim como no módulo sistema de informação, do PDGEP 2.

O tempo para a implementação foi avaliado como adequado. No entanto, foi unânime a observação quanto à dificuldade em conciliar as atividades cotidianas da empresa com a implementação do modelo. 


\begin{tabular}{|c|c|c|c|}
\hline \multicolumn{4}{|c|}{ Tabela 3.7: Organização adotada pelas empresas durante o PDGEP 1} \\
\hline & Responsável Geral & \multicolumn{2}{|c|}{ Arquiteta Titular e Gerente Administrativo. } \\
\hline & $\begin{array}{l}\text { Participantes das } \\
\text { reuniões mensais }\end{array}$ & \multicolumn{2}{|c|}{ Arquiteta Titular e/ou Gerente Administrativo. } \\
\hline 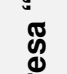 & $\begin{array}{l}\text { Participantes das } \\
\text { reuniões in loco }\end{array}$ & \multicolumn{2}{|c|}{ Arquiteta Titular da empresa e/ou Gerente Administrativo. } \\
\hline 岀 & \multirow{2}{*}{$\begin{array}{l}\text { Estratégia de trabalho } \\
\text { adotada }\end{array}$} & Sistematização & Sistematizado. Através de reuniões periódicas. \\
\hline & & $\begin{array}{l}\text { Envolvimento dos } \\
\text { colaboradores }\end{array}$ & $\begin{array}{l}\text { Nenhum. Todas as tarefas foram desenvolvidas pela } \\
\text { Arquiteta Titular ou Gerente Administrativo. }\end{array}$ \\
\hline \multirow{5}{*}{ 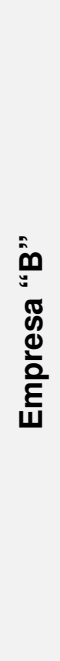 } & Responsável Geral & \multicolumn{2}{|c|}{ Arquiteta Titular da empresa. } \\
\hline & $\begin{array}{l}\text { Participantes das } \\
\text { reuniões mensais }\end{array}$ & \multicolumn{2}{|c|}{ Arquiteta Titular da empresa e todos os arquitetos colaboradores. } \\
\hline & $\begin{array}{l}\text { Participantes das } \\
\text { reuniões in loco }\end{array}$ & \multicolumn{2}{|c|}{ Arquiteta Titular da empresa e todos os arquitetos colaboradores. } \\
\hline & \multirow[t]{2}{*}{$\begin{array}{l}\text { Estratégia de trabalho } \\
\text { adotada }\end{array}$} & Sistematização & $\begin{array}{l}\text { Reuniões semanais. Eram realizadas reuniões } \\
\text { semanais para atribuição de responsabilidades quanto } \\
\text { as tarefas e o seu desenvolvimento, bem como a } \\
\text { verificação e discussão sobre os trabalhos } \\
\text { desenvolvidos na semana anterior. }\end{array}$ \\
\hline & & $\begin{array}{l}\text { Envolvimento dos } \\
\text { colaboradores }\end{array}$ & $\begin{array}{l}\text { Total. O desenvolvimento das tarefas solicitadas e das } \\
\text { ferramentas contava com a participação de todos os } \\
\text { membros da empresa. }\end{array}$ \\
\hline & Responsável Geral & \multicolumn{2}{|l|}{ Arquiteto Titular. } \\
\hline & $\begin{array}{l}\text { Participantes das } \\
\text { reuniões mensais }\end{array}$ & \multicolumn{2}{|c|}{ Arquiteto Titular da empresa. } \\
\hline & $\begin{array}{l}\text { Participantes das } \\
\text { reuniões in loco }\end{array}$ & \multicolumn{2}{|c|}{ Arquiteto Titular da empresa. } \\
\hline & \multirow[t]{3}{*}{$\begin{array}{l}\text { Estratégia de trabalho } \\
\text { adotada }\end{array}$} & Sistematização & $\begin{array}{l}\text { Sem sistematização. As tarefas foram desenvolvidas } \\
\text { na medida em que eram solicitadas. }\end{array}$ \\
\hline 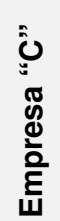 & & $\begin{array}{l}\text { Envolvimento dos } \\
\text { colaboradores }\end{array}$ & $\begin{array}{l}\text { Nenhum. O desenvolvimento das tarefas solicitadas e } \\
\text { das ferramentas era de responsabilidade total do titular } \\
\text { da empresa. Não foi verificado, em nenhum momento } \\
\text { do programa, o envolvimento do outro sócio e } \\
\text { colaboradores. }\end{array}$ \\
\hline & & & Continuação para as demais \\
\hline
\end{tabular}




\begin{tabular}{|c|c|c|c|}
\hline \multirow{5}{*}{ 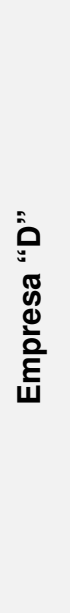 } & Responsável Geral & \multicolumn{2}{|l|}{ Arquiteta Titular. } \\
\hline & $\begin{array}{l}\text { Participantes das } \\
\text { reuniões mensais }\end{array}$ & \multicolumn{2}{|c|}{ Arquiteta Titular da empresa. } \\
\hline & $\begin{array}{l}\text { Participantes das } \\
\text { reuniões in loco }\end{array}$ & \multicolumn{2}{|c|}{ Arquiteta Titular da empresa. } \\
\hline & \multirow[t]{2}{*}{$\begin{array}{l}\text { Método de trabalho } \\
\text { adotado }\end{array}$} & Sistematização & $\begin{array}{l}\text { Sem sistematização. As tarefas foram desenvolvidas } \\
\text { na medida em que eram solicitadas. }\end{array}$ \\
\hline & & $\begin{array}{l}\text { Envolvimento dos } \\
\text { colaboradores }\end{array}$ & $\begin{array}{l}\text { Nenhum. O desenvolvimento das tarefas solicitadas e } \\
\text { das ferramentas era de responsabilidade total da titular } \\
\text { da empresa. Não foi verificado, em nenhum momento } \\
\text { do programa, o envolvimento do colaborador. }\end{array}$ \\
\hline \multirow{5}{*}{ 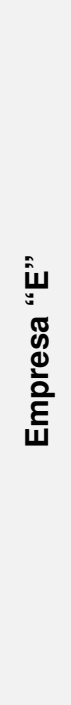 } & Responsável Geral & \multicolumn{2}{|c|}{ Coordenadora de Projetos. } \\
\hline & $\begin{array}{l}\text { Participantes das } \\
\text { reuniões mensais }\end{array}$ & \multicolumn{2}{|c|}{ Titulares da Empresa e dois coordenadores de projeto. } \\
\hline & $\begin{array}{l}\text { Participantes das } \\
\text { reuniões in loco }\end{array}$ & \multicolumn{2}{|c|}{ Um dos Titulares da Empresa e dois coordenadores de projeto. } \\
\hline & \multirow[t]{2}{*}{$\begin{array}{l}\text { Método de trabalho } \\
\text { adotado }\end{array}$} & Sistematização & $\begin{array}{l}\text { Sistematizado. Através da formação de grupos de } \\
\text { trabalho com atividades e agendas pré-estabelecidas. }\end{array}$ \\
\hline & & $\begin{array}{l}\text { Envolvimento dos } \\
\text { colaboradores }\end{array}$ & $\begin{array}{l}\text { Total. O desenvolvimento das tarefas solicitadas e das } \\
\text { ferramentas contava com a participação de todos os } \\
\text { membros da empresa, desde a área administrativa até } \\
\text { a área técnica. As atividades foram desenvolvidas por } \\
\text { grupos de trabalho sob a supervisão de um dos } \\
\text { coordenadores de projeto, que tornou-se, ao longo do } \\
\text { tempo, o responsável interno pelo programa. }\end{array}$ \\
\hline \multirow{6}{*}{ 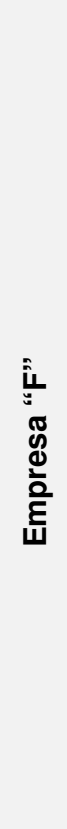 } & Responsável Geral & \multicolumn{2}{|c|}{ Um dos Arquitetos Titulares. } \\
\hline & $\begin{array}{l}\text { Participantes das } \\
\text { reuniões mensais }\end{array}$ & \multicolumn{2}{|c|}{ Arquiteto titular e uma arquiteta colaboradora. } \\
\hline & $\begin{array}{l}\text { Participantes das } \\
\text { reuniões in loco }\end{array}$ & \multicolumn{2}{|c|}{$\begin{array}{l}\text { Arquiteto titular e uma arquiteta colaboradora (ocorreu somente uma reunião } \\
\text { na empresa). }\end{array}$} \\
\hline & \multirow{3}{*}{$\begin{array}{l}\text { Método de trabalho } \\
\text { adotado }\end{array}$} & Sistematização & Não foi possível avaliar. \\
\hline & & $\begin{array}{l}\text { Envolvimento dos } \\
\text { colaboradores }\end{array}$ & Não foi possível avaliar. \\
\hline & & & Conclusão para a ultima \\
\hline
\end{tabular}


Tabela 3.7: Organização adotada pelas empresas durante o PDGEP 1

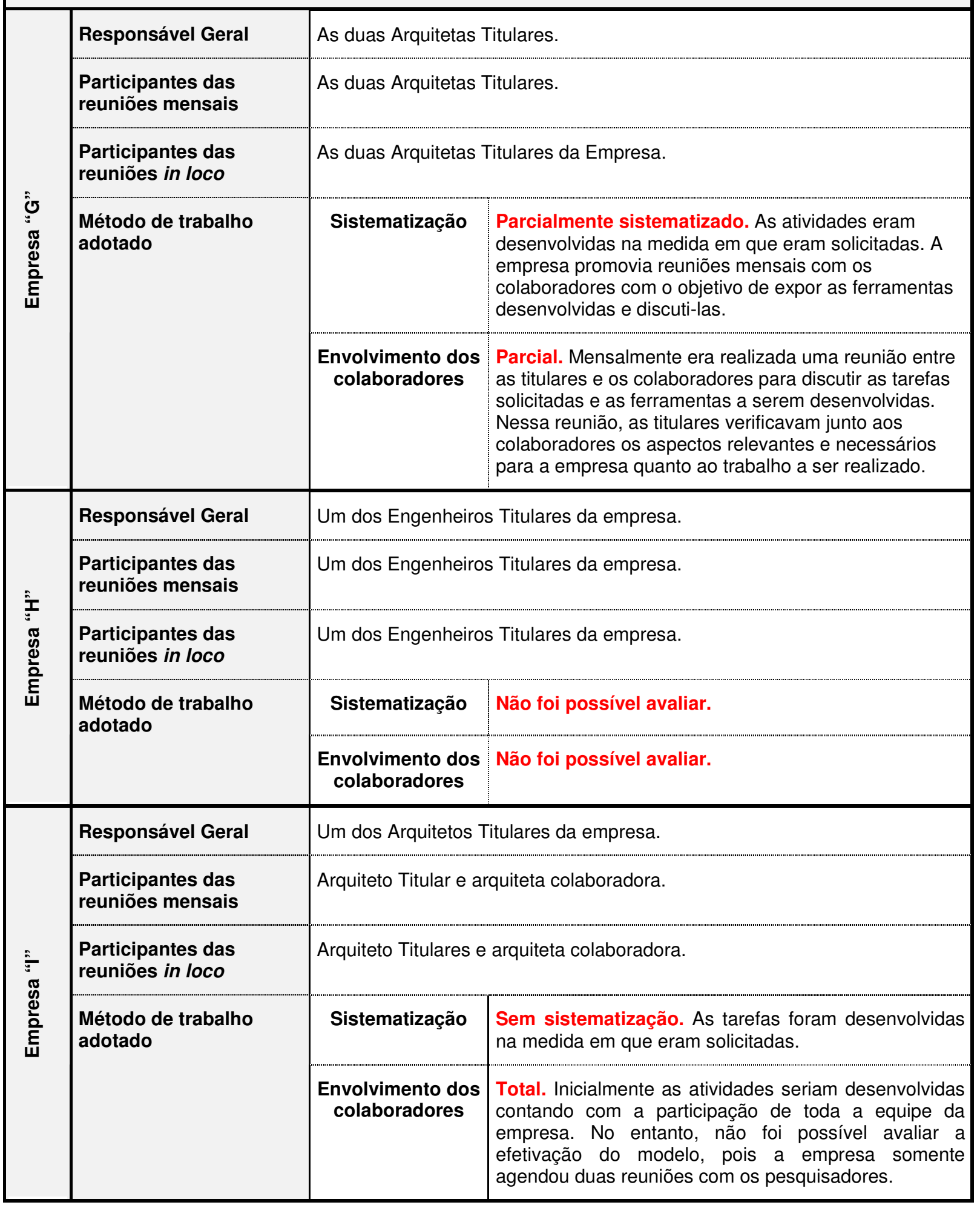




\begin{tabular}{|c|c|c|c|}
\hline \multirow{5}{*}{ 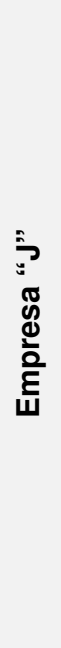 } & Responsável Geral & \multicolumn{2}{|l|}{ Arquiteta Titular. } \\
\hline & $\begin{array}{l}\text { Participantes das } \\
\text { reuniões mensais }\end{array}$ & \multicolumn{2}{|c|}{$\begin{array}{l}\text { Arquiteta Titular, Engenheiro Titular e, eventualmente, a Arquiteta } \\
\text { colaboradora. }\end{array}$} \\
\hline & Participantes das & \multicolumn{2}{|c|}{ Arquiteta Titular e Engenheiro Titular. } \\
\hline & \multirow{2}{*}{$\begin{array}{l}\text { Método de trabalho } \\
\text { adotado }\end{array}$} & Sistematização & Sistematizado. Através de reuniões quinzenais. \\
\hline & & $\begin{array}{l}\text { Envolvimento dos } \\
\text { colaboradores }\end{array}$ & $\begin{array}{l}\text { Parcial. Todas as tarefas e atividades eram } \\
\text { desenvolvidas pela arquiteta e engenheiro titulares. } \\
\text { Não foi verificada a participação dos colaboradores na } \\
\text { implementação do modelo de gestão na empresa. No } \\
\text { entanto, uma das arquitetas colaboradoras participava } \\
\text { das reuniões mensais. }\end{array}$ \\
\hline \multirow{5}{*}{ 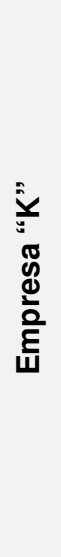 } & Responsável Geral & \multicolumn{2}{|c|}{ Engenheiro Civil Titular. } \\
\hline & $\begin{array}{l}\text { Participantes das } \\
\text { reuniões mensais }\end{array}$ & \multicolumn{2}{|l|}{ Toda a equipe. } \\
\hline & $\begin{array}{l}\text { Participantes das } \\
\text { reuniões in loco }\end{array}$ & \multicolumn{2}{|l|}{ Toda a equipe. } \\
\hline & \multirow[t]{2}{*}{$\begin{array}{l}\text { Método de trabalho } \\
\text { adotado }\end{array}$} & Sistematização & $\begin{array}{l}\text { Sistematizado. Através de reuniões quinzenais com } \\
\text { toda a equipe. }\end{array}$ \\
\hline & & $\begin{array}{l}\text { Envolvimento dos } \\
\text { colaboradores }\end{array}$ & $\begin{array}{l}\text { Total. Todas as tarefas foram desenvolvidas contando } \\
\text { com a participação de toda a equipe, sob a liderança } \\
\text { do Engenheiro Civil Titular. }\end{array}$ \\
\hline \multirow{5}{*}{ 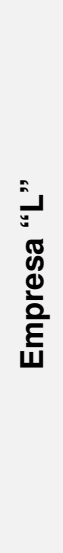 } & Responsável Geral & \multicolumn{2}{|c|}{ Engenheiro Civil Titular. } \\
\hline & $\begin{array}{l}\text { Participantes das } \\
\text { reuniões mensais }\end{array}$ & \multicolumn{2}{|c|}{ Engenheiro Civil Titular. } \\
\hline & $\begin{array}{l}\text { Participantes das } \\
\text { reuniões in loco }\end{array}$ & \multicolumn{2}{|c|}{ Engenheiro Civil Titular. } \\
\hline & \multirow[t]{2}{*}{$\begin{array}{l}\text { Método de trabalho } \\
\text { adotado }\end{array}$} & Sistematização & $\begin{array}{l}\text { Sem sistematização. As tarefas e ferramentas eram } \\
\text { desenvolvidas na medida em que eram solicitadas. }\end{array}$ \\
\hline & & $\begin{array}{l}\text { Envolvimento dos } \\
\text { colaboradores }\end{array}$ & $\begin{array}{l}\text { Nenhum. Até o momento em que participou do } \\
\text { programa, todas as tarefas eram desenvolvidas pelo } \\
\text { Engenheiro Civil Titular. }\end{array}$ \\
\hline \multirow{5}{*}{ 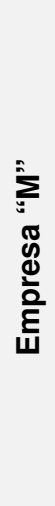 } & Responsável Geral & \multicolumn{2}{|l|}{ Engenheiro Titular. } \\
\hline & $\begin{array}{l}\text { Participantes das } \\
\text { reuniões mensais }\end{array}$ & \multicolumn{2}{|l|}{ Engenheiro Titular. } \\
\hline & $\begin{array}{l}\text { Participantes das } \\
\text { reuniões in loco }\end{array}$ & \multicolumn{2}{|l|}{ Engenheiro Titular. } \\
\hline & \multirow[t]{2}{*}{$\begin{array}{l}\text { Método de trabalho } \\
\text { adotado }\end{array}$} & Sistematização & $\begin{array}{l}\text { Sem sistematização. As tarefas e ferramentas eram } \\
\text { desenvolvidas na medida em que eram solicitadas. }\end{array}$ \\
\hline & & $\begin{array}{l}\text { Envolvimento dos } \\
\text { colaboradores }\end{array}$ & $\begin{array}{l}\text { Nenhum. Todas as tarefas eram desenvolvidas pelo } \\
\text { Engenheiro Titular. }\end{array}$ \\
\hline
\end{tabular}




\begin{tabular}{|c|c|c|c|}
\hline \multicolumn{4}{|c|}{ Tabela 3.8: Sistemática de trabalho adotada pelas empresas durante o PDGEP 2} \\
\hline \multirow{5}{*}{ 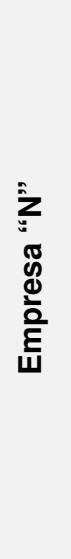 } & Responsável Geral & \multicolumn{2}{|l|}{ Arquitetas titulares. } \\
\hline & $\begin{array}{l}\text { Participantes das } \\
\text { reuniões mensais }\end{array}$ & \multicolumn{2}{|l|}{ Arquitetas titulares. } \\
\hline & $\begin{array}{l}\text { Participantes das } \\
\text { reuniões in loco }\end{array}$ & \multicolumn{2}{|l|}{ Arquitetas titulares. } \\
\hline & \multirow[t]{2}{*}{$\begin{array}{l}\text { Método de trabalho } \\
\text { adotado }\end{array}$} & Sistematização & $\begin{array}{l}\text { Sistematizado. Reuniões quinzenais eram realizadas } \\
\text { com o objetivo de discutir o desenvolvimento gerencial } \\
\text { da empresa e desenvolver ferramentas pertinentes. }\end{array}$ \\
\hline & & $\begin{array}{l}\text { Envolvimento dos } \\
\text { colaboradores }\end{array}$ & $\begin{array}{l}\text { Nenhum. A empresa não contava com colaboradores; } \\
\text { a equipe era formada apenas pelas arquitetas titulares. }\end{array}$ \\
\hline \multirow{5}{*}{ 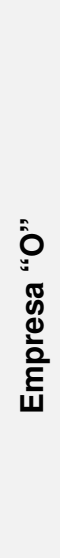 } & Responsável Geral & \multicolumn{2}{|l|}{ Arquitetas titulares. } \\
\hline & $\begin{array}{l}\text { Participantes das } \\
\text { reuniões mensais }\end{array}$ & \multicolumn{2}{|l|}{ Arquitetas titulares. } \\
\hline & $\begin{array}{l}\text { Participantes das } \\
\text { reuniões in loco }\end{array}$ & \multicolumn{2}{|l|}{ Arquitetas titulares. } \\
\hline & \multirow[t]{2}{*}{$\begin{array}{l}\text { Método de trabalho } \\
\text { adotado }\end{array}$} & Sistematização & $\begin{array}{l}\text { Sem sistematização. As tarefas e ferramentas eram } \\
\text { desenvolvidas na medida em que eram solicitadas. }\end{array}$ \\
\hline & & $\begin{array}{l}\text { Envolvimento dos } \\
\text { colaboradores }\end{array}$ & $\begin{array}{l}\text { Nenhum. Todas as tarefas foram desenvolvidas pelas } \\
\text { titulares da empresa, sem a participação da sua única } \\
\text { colaboradora. }\end{array}$ \\
\hline \multirow{5}{*}{ 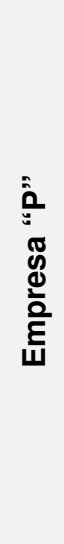 } & Responsável Geral & \multicolumn{2}{|l|}{ Arquiteta titular. } \\
\hline & $\begin{array}{l}\text { Participantes das } \\
\text { reuniões mensais }\end{array}$ & \multicolumn{2}{|l|}{ Arquiteta titular. } \\
\hline & $\begin{array}{l}\text { Participantes das } \\
\text { reuniões in loco }\end{array}$ & \multicolumn{2}{|c|}{ Arquiteta titular e colaboradores. } \\
\hline & $\begin{array}{l}\text { Método de trabalho } \\
\text { adotado }\end{array}$ & Sistematização & $\begin{array}{l}\text { Sem sistematização. As tarefas e ferramentas eram } \\
\text { desenvolvidas na medida em que eram solicitadas. }\end{array}$ \\
\hline & & $\begin{array}{l}\text { Envolvimento dos } \\
\text { colaboradores }\end{array}$ & $\begin{array}{l}\text { Total. Até o momento em que participou do programa, } \\
\text { todas as atividades e tarefas eram realizadas com o } \\
\text { envolvimento dos colaboradores. }\end{array}$ \\
\hline
\end{tabular}

As Tabelas 3.7 e 3.8 ilustram a sistemática de trabalho adotada pelas empresas na implementação do modelo durante os PDGEP 1 e 2, respectivamente. A descrição da organização adotada pelas empresas na implementação do modelo, das tarefas realizadas e das dificuldades na sua realização subsidiam a análise quanto a reação das empresas na aplicação do modelo, e complementam as considerações para proposição de diretrizes, a fim de facilitar a implementação do modelo, objetivo deste trabalho. 
Através das Tabelas 3.7 e 3.8, verifica-se que somente a empresa "E" delegou a responsabilidade sobre a implementação do modelo à coordenadora de projetos. Se analisadas as Tabelas 3.5 e 3.6, a empresa "E" desenvolveu e operacionalizou a maior parte das tarefas solicitadas e ferramentas.

Percebeu-se que as empresas cujo método de trabalho adotado foi sistematizado através de freqüentes reuniões e envolvimento dos colaboradores, foram as que conseguiram ampliar o desempenho no desenvolvimento de ferramentas e operacionalizá-las, à exemplo das empresas "A", "B" e "E" no primeiro grupo, e "J", "K" e "N" no segundo grupo, consoante Tabelas 3.5 e 3.6.

Como já destacado anteriormente, ao aderirem ao programa de desenvolvimento gerencial, as empresas assumiram o compromisso de implementar o modelo de gestão proposto por Oliveira (2005) através do desenvolvimento das tarefas solicitadas pelos pesquisadores ao longo do PDGEP 1 e PDGEP 2.

A primeira reunião de ambos os programas expôs para as empresas que 0 planejamento e organização constantes no desenvolvimento das tarefas são ações necessárias para a eficácia da implementação do modelo, uma vez que somente a realização das tarefas na medida em que são solicitadas, sem reflexão e discussões junto aos colaboradores, não garantem o desenvolvimento gerencial.

Contudo, a maioria das empresas apontou dificuldades ao ser questionada sobre a conciliação da implementação do modelo com as suas atividades cotidianas.

Logo, tanto as empresas do PDGEP 1 quanto PDGEP 2 sugeriram a inserção de um módulo inicial cujo objetivo seria o de trabalhar o desenvolvimento de ferramentas e procedimentos voltados à implementação do modelo de gestão.

Portanto, deve estar claro para as empresas que, ao se decidirem pela implementação do modelo de gestão, devem tratá-lo como um projeto, com consumo de recursos (pessoas, tempo, dinheiro) e, portanto, com a necessidade de ser gerido através de planejamento, acompanhamentos, controles e retroalimentação.

As dificuldades na implementação do modelo foram separadas em duas: dificuldades específicas, mostradas na Tabela 3.9, e dificuldades gerais, detectadas em todos os módulos do programa e que, no seu decorrer e na medida do possível, 
foram solucionadas através de discussões, exposições e dinâmicas de grupo visando a autocrítica e, consequentemente, o autodesenvolvimento.

\begin{tabular}{|c|c|}
\hline \multicolumn{2}{|r|}{$\begin{array}{l}\text { Tabela 3.9: Resumo das dificuldades específicas das empresas no desenvolvimento das } \\
\text { tarefas referentes a cada um dos módulos durante o PDGEP } 1 \text { e PDGEP } 2\end{array}$} \\
\hline Tópico & Dificuldades do desenvolvimento das tarefas \\
\hline 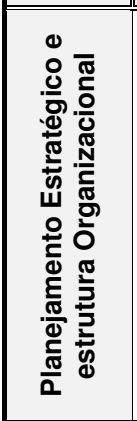 & $\begin{array}{l}\text { - } \quad \text { Dificuldade na sistematização ao planejar tanto estrategicamente quanto operacionalmente. } \\
\text { - } \quad \text { maior parte das empresas não consegue realizar a análise interna, externa e nem mesmo } \\
\text { - } \quad \text { Definição de objetivos, metas e indicadores estratégicos. } \\
\text { - } \quad \text { forma simples e objetiva. } \\
\text { - Não realizam adequadamente o reconhecimento mercadológico, portanto, na definição da missão } \\
\text { - } \text { vifão dessas empresas, detectou-se alto grau de incoerência com a realidade em que atuam. } \\
\text { - Dificuldade em definir as funções e o seu limite de responsabilidade } \\
\text { empresa. }\end{array}$ \\
\hline 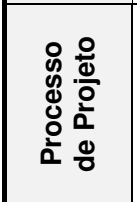 & $\begin{array}{l}\text { - Apesar de muitas vezes possuírem ferramentas e/ou métodos de controle, as empresas não têm } \\
\text { - } \quad \text { Densciência de que os possui e, portanto, não os utilizam de maneira adequada. } \\
\text { empresa desenvolve } \\
\text { - Colocação em prática do uso das ferramentas de controle desenvolvidas. }\end{array}$ \\
\hline 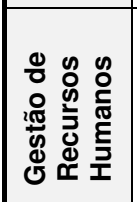 & $\begin{array}{l}\text { - Definição de um plano de treinamento coerente com as necessidades e possibilidades financeiras } \\
\text { da empresa. } \\
\text { - Na definição de diretrizes para a terceirização tanto do ponto de vista do contratante quanto do } \\
\text { contratado. De forma geral, as empresas de projeto têm dificuldade em assumir a terceirização } \\
\text { como uma realidade mercadológica. }\end{array}$ \\
\hline 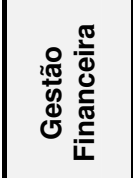 & $\begin{array}{l}\text { - Idéia equivocada de que a organização do processo financeiro é demasiadamente complexa, } \\
\text { levando a conclusões extremas de que esse trabalho deva ser realizado por um especialista. } \\
\text { - Caracterização do fluxo de informações referente ao processo de gestão financeira. } \\
\text { - Uso de aplicativos como Excel no desenvolvimento geral de ferramentas para a gestão financeira. }\end{array}$ \\
\hline 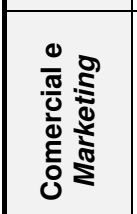 & $\begin{array}{l}\text { - Resistência ao reconhecimento de que as práticas correntes da empresa quanto à gestão } \\
\text { comercial não são as mais adequadas, principalmente aquelas relacionadas à elaboração de } \\
\text { propostas técnicas. } \\
\text { Desconhecimento de técnicas de marketing aplicáveis às empresas de projeto, em função de suas } \\
\text { características particulares e de seus produtos e serviços. }\end{array}$ \\
\hline 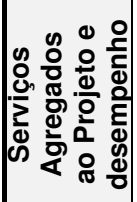 & $\begin{array}{l}\text { - Identificar qual a forma e a ferramenta mais adequadas para a realização de pesquisa de } \\
\text { satisfação de clientes e avaliação pós-ocupação. } \\
\text { Em função dos relacionamentos com clientes, estabelecer como escopo do projeto as visitas } \\
\text { técnicas sistemáticas às obras. }\end{array}$ \\
\hline 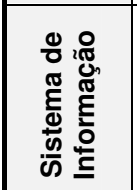 & $\begin{array}{l}\text { - Identificação do fluxo de informações referentes aos diversos processos da empresa (técnicos e } \\
\text { - } \quad \text { Defministrativos). } \\
\text { organizaçãão e disponibilização da informação. }\end{array}$ \\
\hline
\end{tabular}

As dificuldades gerais referem-se principalmente aos seguintes aspectos: 
- Desconhecimento generalizado dos conceitos relacionados à gestão: As empresas apresentam dificuldade na compreensão do vocabulário e dos termos e conceitos relacionados à gestão de empresas.

- Objetivos e metas a serem alcançados em função da participação no programa: De modo geral, as empresas são conscientes de suas limitações e dificuldades gerenciais. No entanto, percebeu-se que, para algumas empresas, não estavam claros os objetivos a serem atingidos através do trabalho de desenvolvimento gerencial, e esse foi um dos principais fatores de desmotivação, pois tinham a expectativa inicial de que o modelo ofereceria soluções prontas ao invés do direcionamento para a discussão e análise individualizada quanto as suas características particulares e deficiências específicas de cada uma das empresas.

- Identificação das interfaces entre os diversos elementos de gestão: Ao desenvolverem as tarefas relativas a cada um dos módulos, as empresas, em principio, não consideraram as interfaces entre os diversos processos de gestão (projeto, recursos humanos, recursos financeiros, informação, comercial, desempenho). Verificou-se durante a pesquisa que a falta de visão sistêmica em relação a gestão levou as empresas ao desenvolvimento de soluções isoladas e, consequentemente, ferramentas gerenciais ineficazes.

- As empresas de projeto não estão acostumadas a planejar cotidianamente: De forma geral, as empresas de projeto não sistematizam a sua rotina diária de trabalho através de planejamento. Por princípio, a implementação do modelo de gestão proposto é um trabalho adicionado à rotina diária da empresa e, portanto, exige, como qualquer outro projeto a ser desenvolvido, investimentos de tempo e dedicação de pessoal. Após análise, percebeu-se que em ambos os grupos, em princípio, as empresas não se deram conta dessa situação e, consequentemente, não se planejaram para tal. Nesse sentido, procurou-se trabalhar continuamente a elaboração de planos de ação para o desenvolvimento dos trabalhos de cada um dos módulos, pois do contrário, esse poderia ser um dos fatores de desmotivação para a continuidade das empresas no programa, como de fato ocorreu para algumas empresas. 
- Desenvolvimento de indicadores e desconhecimento das vantagens das práticas de gestão por desempenho: Percebeu-se, de forma geral, que algumas empresas, ao desenvolverem indicadores e ferramentas relacionadas, o fizeram de forma que sua alimentação fosse altamente complexa, tornando sua utilização inviável para o dia-a-dia da pequena empresa de projeto. Em contrapartida, outras empresas estabeleceram indicadores óbvios demais, cujas informações fornecidas seriam pouco relevantes para a gestão da empresa. Uma vez que, em ambos os grupos, as duas situações foram identificadas, procurouse trabalhar ao longo dos programas o autoconhecimento no sentido de despertar, por parte das empresas, a percepção sobre as suas reais necessidades, limitações e potencialidades.

- Uso e análise crítica das ferramentas desenvolvidas: Ao desenvolverem as ferramentas e procedimentos solicitados durante o programa, percebeu-se grande dificuldade das empresas em colocá-los em prática e, posteriormente, analisar criticamente com objetivo de os aperfeiçoar e tornar coerentes com as suas características específicas e reais necessidades.

- Dificuldade dos titulares em delegar atividades e responsabilidades referentes à implementação do modelo: Como é de conhecimento comum, a concentração de responsabilidades no profissional titular ocorre cotidianamente nas empresas de projeto e, ao longo dos programas, verificou-se a repetição de tal prática em relação à implementação do modelo de gestão. Algumas empresas chegaram ao extremo de não envolver os colaboradores em nenhuma das atividades de desenvolvimento gerencial, dificultando, dessa forma, a obtenção de resultados relacionados à gestão. Por outro lado, a maior parte das empresas cujos colaboradores foram envolvidos em todas as etapas, tinham como líder do processo o profissional titular. Em ambos os grupos, a única empresa que delegou a responsabilidade de condução do programa a um colaborador foi a empresa cuja implementação transcorreu de forma mais organizada e com resultados visíveis, mesmo durante a etapa de implementação.

Uma vez que as dificuldades gerais detectadas durante o PDGEP 1 e o PDGPE 2 assemelham-se às deficiências elencadas na tese de Doutorado de Oliveira (2005), as quais embasaram a elaboração do referido modelo de gestão e foram 
mencionadas no Item 1.1 - Objetivos e Justificativa, percebe-se a confirmação da necessidade de aperfeiçoamento gerencial por parte das empresas de projeto enfatizado pelo autor.

\subsection{Análise da Aplicação do Modelo de Gestão: Resultados alcançados pelas empresas em função da implementação do modelo de gestão}

Os resultados do trabalho desenvolvido durante o PDGEP1 e PDGEP 2 em função da implementação do modelo de gestão proposto por Oliveira (2005) podem ser analisados sob diversos pontos de vista. Um deles enfoca naturalmente as melhorias e evoluções gerenciais alcançadas pelas empresas através do desenvolvimento de ferramentas e procedimentos gerenciais.

No entanto, as mudanças e evoluções percebidas não se referem somente a esses aspectos, uma vez que a análise de resultados restrita ao desenvolvimento de tarefas propostas durante os programas pode levar a considerações simplistas do ponto de vista dos objetivos do trabalho.

Ao longo do programa, verificaram-se, por parte dos titulares e colaboradores, mudanças sutis relacionadas principalmente à postura com relação a organização e à tomada de decisão nas empresas.

A seguir, serão relatadas três experiências vivenciadas por empresas participantes do PDGEP 2, e que têm por objetivo retratar as mudanças de postura citadas e descrever problemas singulares a essas empresas, cujas análises e soluções as remeteram ao desenvolvimento gerencial.

A primeira situação ocorreu na empresa "M", participante do PDGEP 2. A experiência está descrita de forma mais detalhada em Souza et al. (2008) e, em linhas gerais, procura demonstrar a aplicação do modelo de Oliveira (2005) como método para condução das análises referentes à decisão pela aquisição de uma ferramenta de trabalho, no caso, um software para simulação acústica.

Entre outros aspectos relatados, observou-se que o conhecimento das interfaces entre os diversos subsistemas da empresa garante que análises estratégicas sejam 
feitas de forma adequada, permitindo uma avaliação dos impactos e benefícios associados às ações primárias - neste caso, a compra e utilização do software.

A experiência relatada é um exemplo claro da mudança de postura com relação à tomada de decisão na empresa de projeto, além de mostrar que o modelo proposto por Oliveira (2005) não se restringe ao desenvolvimento de procedimentos e normas gerenciais. Nota-se que os conceitos propostos são aplicáveis tanto na reestruturação da empresa de projeto no sentido mais amplo da gestão, quanto em análises rotineiras, como é o caso da aquisição do software de trabalho, que interferirá diretamente no processo de projeto e nos demais processos de gestão.

O segundo caso refere-se a análise gerencial financeira e de recursos humanos, levando-se em consideração as interfaces entre os dois processos na empresa, conforme Souza et al. (2008).

A experiência ocorreu na empresa "J", participante do PDGEP 2, e retrata as melhorias e evoluções gerenciais por ela alcançadas em função da análise realizada sobre os processos relacionados e o posterior desenvolvimento de ferramentas.

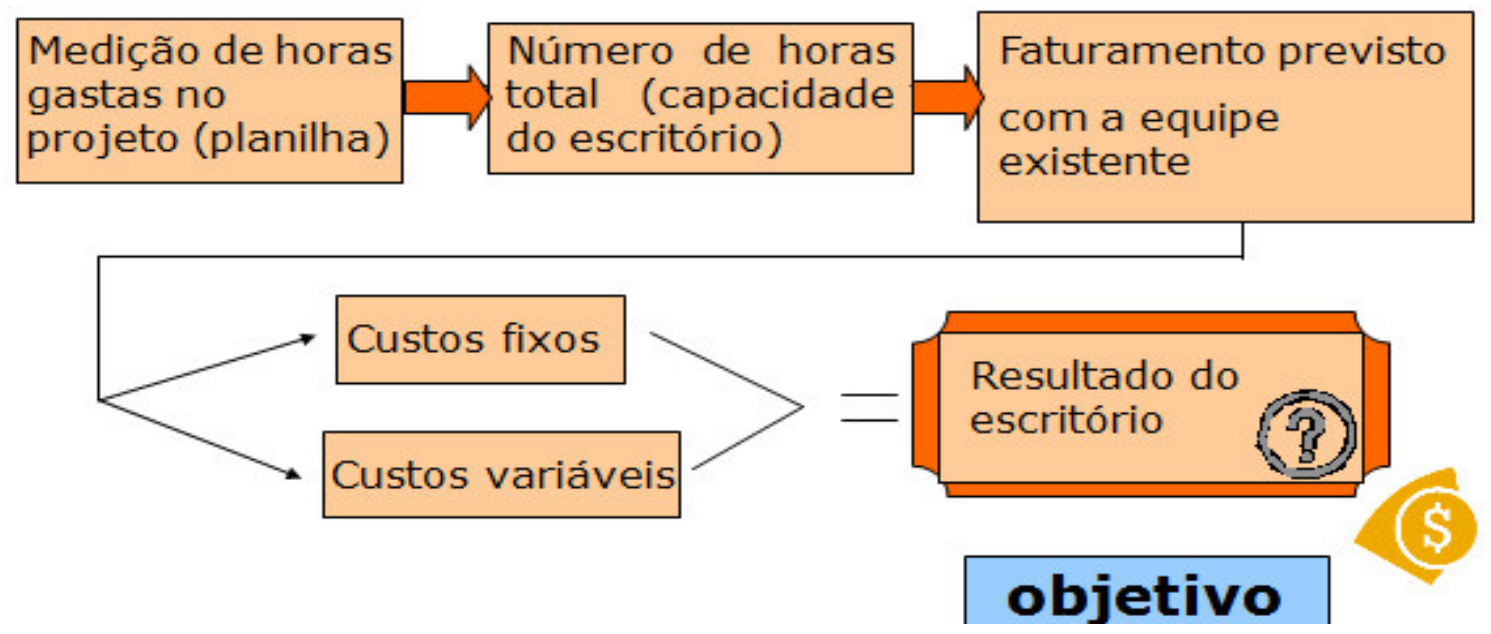

Figura 3.3: Seqüência das etapas de análise pertinentes aos processos de gestão financeira e de recursos humanos

Através das análises pertinentes aos dois processos, conforme mostra a Figura 3.3, a empresa desenvolveu ferramentas para controle e análise financeira, de forma a direcionar contratações, estabelecendo algumas prioridades, tais como: conhecimento de programas, tempo de experiência e nível de escolaridade.

Tal experiência ressalta a importância da visão sistêmica e de interfaces entre os diversos elementos de gestão quando da implementação do modelo, além de demonstrar um exemplo da capacidade das pequenas empresas de projeto em 
desenvolver ferramentas simples e eficazes, de forma a aprimorar habilidades a partir de orientações e esclarecimentos que, uma vez colocados em prática através de atividades gerenciais, agregaram valor ao processo e ao produto final da empresa, viabilizando, dessa forma, sua atividade-fim, qual seja, a atividade projetual.

A terceira experiência descrita trata do desenvolvimento de ferramentas voltadas ao controle do processo de projeto, em função da tarefa solicitada no PDGEP 2 (planejamento de um dos projetos da empresa em fase inicial, abrangendo os seguintes aspectos: emprego dos recursos; comunicação; tratamento das informações; controle da qualidade; controle do planejamento; definição de indicadores de desempenho).

$\mathrm{Na}$ empresa "J", os dois titulares participam de todos os projetos executados e detêm grande parte das decisões, coordenação e supervisão. Essa característica deve-se ao fato da ausência de ferramentas e, consequentemente, da dificuldade de visualizar o quadro geral de pessoas e respectivas responsabilidades, a fim de possibilitar a designação de mais responsabilidades aos colaboradores.

O tempo gasto em cada uma das etapas de projeto não está relacionado ao seu tamanho, e sim à sua complexidade, ou seja, projetos de residências podem apresentar grau de complexidade maior e demandar mais tempo no seu desenvolvimento do que projetos de edifícios multipavimentos.

Além disso, a elaboração do projeto é feita de acordo com a data de entrega e a entrada de dados necessários, e o projeto depende das interfaces com outras especialidades, tais como arquitetura, estrutura em concreto e/ou metálica (ocorrendo em paralelo); porém, tudo é informal. Apesar de não possuírem planejamento do processo de projeto formalizado, a primeira etapa referente ao trabalho de projeto é a análise da arquitetura, cuja finalidade é definir o sistema a ser utilizado para iniciar o detalhamento. Muitas vezes, por falta de informação do projeto de arquitetura, projetos aparentemente simples tornam-se complexos.

A ferramenta produzida pela empresa consiste em uma tabela com as etapas para o planejamento do Processo de Projeto e a alocação da estimativa de tempo e respectivas responsabilidades que, posteriormente, será comparado com o tempo 
real gasto para a realização da tarefa. A tabela também especifica como se dará a comunicação interna e externa do projeto em questão.

\begin{tabular}{|c|c|c|c|c|c|c|}
\hline Etapas & Tempo Previsto & Titular 1 & Titular 2 & Arquiteto & Estagiário & Tempo Real \\
\hline $\begin{array}{l}\text { Recebimento das informações } \\
\text { de arquitetura }\end{array}$ & - & - & - & - & - & \\
\hline $\begin{array}{l}\text { Análise das informações de } \\
\text { arquitetura }\end{array}$ & 24 horas & 8 horas & 8 horas & & 8 horas & \\
\hline $\begin{array}{l}\text { Planilha de tipos e quantidades } \\
\text { dos caixilhos a serem } \\
\text { projetados }\end{array}$ & 16 horas & - & - & 8 horas & 8 horas & \\
\hline Definição dos sistemas & 6 horas & - & 6 horas & - & - & \\
\hline Confecção dos desenhos. & 80 horas & - & 20 horas & 40 horas & 20 horas & \\
\hline \multirow{2}{*}{$\begin{array}{l}\text { Conferência dos desenhos. } \\
\text { Elaboração de memorial } \\
\text { descritivo }\end{array}$} & 8 horas & 4 horas & 4 horas & - & - & \\
\hline & 4 horas & 4 horas & - & - & - & \\
\hline Entrega - Saída & - & - & - & - & - & \\
\hline \multicolumn{7}{|c|}{$\begin{array}{l}\text { Comunicação Externa - Email com cópias internas (armazenados no outlook), ATAS (arquivadas na pasta do projeto) e } \\
\text { telefone. } \\
\text { Comunicação Interna - ATAS (arquivadas na pasta do } \\
\text { projeto) }\end{array}$} \\
\hline
\end{tabular}

Figura 3.4 - Planejamento das etapas de trabalho de um projeto genérico da empresa "J"

A quarta experiência refere-se à Empresa "k", cujo o processo de projeto é condicionado pela alta rotatividade e pelo ciclo de duração reduzido de seus projetos (em torno de uma semana). A coordenação e verificação dos projetos é centralizada em um dos sócios titulares, assim como a maioria dos contatos com os clientes.

A maior dificuldade identificada na etapa de planejamento do processo de projeto foi o planejamento do tempo e a distribuição dos recursos humanos dentro da empresa, prejudicando a dinâmica do ciclo de entrada, o desenvolvimento e a conclusão dos projetos, que dependiam da verificação de um único coordenador em todas as etapas.

Além disso, o monitoramento das atividades no escritório ocorre informalmente, e as ferramentas de controle desenvolvidas (listas de verificação dos itens de documentos a serem enviados, desenvolvidas somente para projetos de combate à incêndio) não eram utilizadas.

A primeira etapa do trabalho consistiu no mapeamento do processo de projeto genérico da empresa através de macrofluxo e foi fundamental, pois segundo um dos sócios, o encaminhamento das atividades era desconhecido por parte dos colaboradores da empresa. 


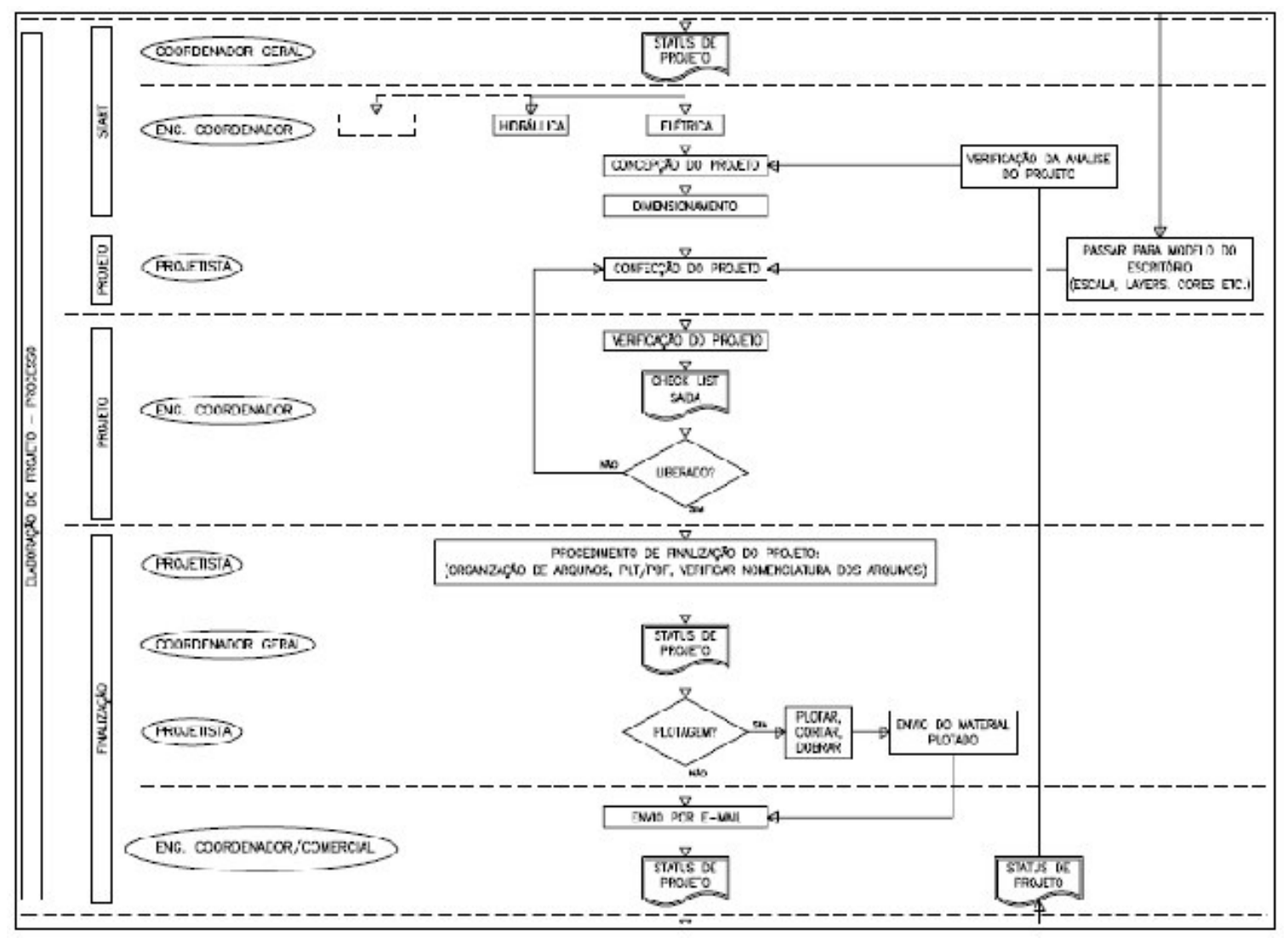

Figura 3.5 - Macro Fluxo Genérico das etapas de trabalho dos Projetos desenvolvidos pela empresa " $K$ "

O trabalho de planejamento do tempo da empresa seguiu uma escala semanal, mais adequada à rotina acelerada dos projetos. Foram desenvolvidas listas de verificação para todas as especialidades de instalações prediais que a empresa desenvolve, e uma planilha de controle de horas que permitisse um melhor monitoramento do tempo gasto por cada funcionário em atividades de produção, correção e revisão. 


\begin{tabular}{|c|c|c|c|c|c|c|c|c|c|c|c|c|c|}
\hline \multirow{3}{*}{ proj. } & \multirow{3}{*}{ rev. } & \multirow{3}{*}{ resp. } & \multirow{3}{*}{ obra } & \multirow{3}{*}{ local } & \multirow{3}{*}{ núm } & \multirow{3}{*}{$\begin{array}{l}\text { data do } \\
\text { fech. }\end{array}$} & \multirow{3}{*}{$\begin{array}{c}\text { receb. do } \\
\text { arq. / dados }\end{array} \mid$} & \multirow{3}{*}{$\begin{array}{l}\text { prev. de } \\
\text { entrega } \\
\text { CONTR. }\end{array}$} & \multirow{3}{*}{$\begin{array}{c}\text { prev. de } \\
\text { entrega } \\
\text { REAL }\end{array}$} & \multirow{3}{*}{$\begin{array}{c}\text { data de } \\
\text { finaliz. do } \\
\text { projeto }\end{array}$} & \multicolumn{3}{|c|}{ envio de arquivos } \\
\hline & & & & & & & & & & & arq. & constr. & propr. \\
\hline & & & & & & & & & & & data & data & data \\
\hline ELE & 00 & ASK & NONONO & CID. JARDIM SHOP. & 75 & 27-jan & 28-jan & 4-fev & 4-fev & 4-fev & 4-fev & 4-fev & $\bar{x}$ \\
\hline ELE & 01 & ASK & NONONO & CID. JARDIM SHOP. & 75 & 27-jan & $10-$ fev & 12-fev & 12-fev & 12 -fev & 13-fev & 13-fev & $x$ \\
\hline SPK & 00 & LHTF & NONONO & CID. JARDIM SHOP. & 75 & 27-jan & 28-jan & 4-fev & 4-fev & 4-fev & 4-fev & 4-fev & $\mathrm{X}$ \\
\hline SPK & 01 & LHTF & NONONO & CID. JARDIM SHOP. & 75 & 27-jan & $10-$ fev & 12-fev & 12-fev & 12-fev & 13-fev & 13-fev & $\mathrm{X}$ \\
\hline SPK & 02 & LHTF & NONONO & CID. JARDIM SHOP. & 75 & 27-jan & 15-fev & 16-fev & 16-fev & 16-fev & 16-fev & 16-fev & $x$ \\
\hline EST & 00 & CBB & NONONO & CID. JARDIM SHOP. & 75 & 27-jan & 28-jan & 4-fev & 2-fev & 2-fev & 2-fev & 2-fev & $\mathrm{X}$ \\
\hline EST & 01 & CBB & NONONO & CID. JARDIM SHOP. & 75 & 27-jan & 5-fev & 6-fev & 6-fev & 6-fev & 6-fev & 6-fev & $\mathrm{x}$ \\
\hline HID & 00 & LP & NONONO & CID. JARDIM SHOP. & 75 & 27-jan & 28-jan & 4-fev & 4-fev & 4-fev & 4-fev & 4-fev & $\mathrm{X}$ \\
\hline ELE & 00 & ASK & NONO & BOURBON SHOP. & $33 / 34-M$ & 20-mai & 25-mai & 1-jun & 1-jun & & & & \\
\hline SPK & 00 & LHTF & NONO & BOURBON SHOP. & 33/34-M & 20-mai & 25-mai & 1-jun & 1-jun & & & & \\
\hline EST & 00 & CBB & NONO & BOURBON SHOP. & $33 / 34-M$ & 20-mai & 25-mai & 1-jun & 30-mai & & & & \\
\hline
\end{tabular}

\begin{tabular}{|c|c|c|c|c|c|}
\hline \multirow[b]{2}{*}{ proj. } & \multirow[t]{2}{*}{ rev. } & \multicolumn{4}{|c|}{ Aprovação de Projetos } \\
\hline & & $\begin{array}{l}\text { data de } \\
\text { entrega }\end{array}$ & status & $\begin{array}{c}\text { dala } \\
\text { previsão/ } \\
\text { análise }\end{array}$ & $o b s$ \\
\hline ELE & 00 & 5-fev & aprov. com ressalvas & 10-fev & Entregue para Souza Lima dar entrada \\
\hline ELE & 01 & 13-fev & APROVADO & $15-\mathrm{fev}$ & confirmado recebimento $\mathrm{c} /$ Vinicius \\
\hline SPK & 00 & 5-fev & REPROVADO & 10-fev & Entregue para Souza Lima dar entrada \\
\hline SPK & 01 & 13-fev & aprov. com ressalvas & 15-fev & confirmado recebimento c/ Vinicius \\
\hline SPK & 02 & 16 -fev & APROVADO & 18-fev & enviado p/ Fábio assinar; confirmado recebimento; ele entregará no shop. \\
\hline EST & 00 & 2-fev & aprov. com ressalvas & 5-fev & Entregue para Souza Lima dar entrada \\
\hline EST & 01 & 6-fev & APROVADO & $10-$ fev & Entregue para Souza Lima dar entrada \\
\hline HID & 00 & 5 -fev & APROVADO & $10-$ fev & Entregue para Souza Lima dar entrada \\
\hline ELE & 00 & & DAR ENTRADA & & \\
\hline SPK & 00 & & DAR ENTRADA & & \\
\hline EST & 00 & & DAR ENTRADA & & \\
\hline
\end{tabular}

Figura 3.6 - Ferramentas desenvolvidas pelas empresa "K" para controle das etapas dos projetos : Agenda Semanal e Status de Projeto

Os casos estão mais bem detalhados em Souza et al. (2008); no entanto, em linhas gerais, procurou-se sintetizar, através do relato das experiências, o resultado das ferramentas desenvolvidas, já que a proposição geral da tarefa não se aplicava à realidade das empresas em questão. Dessa forma, interpretações e análises internas foram realizadas no sentido de desenvolver ferramentas voltadas ao planejamento e ao controle do processo de projeto, compatíveis com as dinâmicas de trabalho das empresas e com as características específicas dos projetos por elas desenvolvidos.

Além disso, os casos mostram como essencial a predisposição das empresas em interpretarem adequadamente as diretrizes genéricas do modelo de gestão, uma vez que 0 adequado desenvolvimento gerencial está diretamente atrelado ao autoconhecimento.

Portanto, a organização das empresas, o desenvolvimento de ferramentas e os procedimentos devem ser conduzidos de acordo com suas limitações e características particulares, pois a aplicação e operacionalização de soluções 
prontas e ferramentas genéricas podem levar as empresas ao risco de desgaste gerencial e, consequentemente, comprometer a sua competitividade.

Outra análise a ser realizada em função dos resultados alcançados pelas empresas refere-se à continuidade do desenvolvimento gerencial após a finalização dos programas, através do uso ininterrupto de ferramentas e procedimentos, bem como seu posterior aperfeiçoamento, conforme ilustrado nas Tabelas 3.10 e 3.11.

As informações relacionadas à continuidade do desenvolvimento gerencial foram obtidas através do questionário final, citado no Item 3.3 - Programa de desenvolvimento gerencial para empresas de projeto: etapa da implementação do modelo de gestão. 


\begin{tabular}{|c|c|c|c|c|c|c|c|c|c|c|}
\hline \multirow{2}{*}{ Tópico } & \multirow{2}{*}{ Aspecto questionado } & \multicolumn{9}{|c|}{ Empresas } \\
\hline & & A & B & C & D & E & $\mathbf{F}$ & G & H & $\mathbf{I}$ \\
\hline \multirow{6}{*}{ 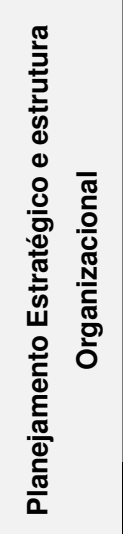 } & Foram mantidas e estão em uso - Nota 7 & & & & & & & 7 & & \\
\hline & Foram mantidas, mas não são utilizadas - Nota 4 & & & & & & & & & \\
\hline & Foram reformuladas e estão em uso - Nota 10 & 10 & 10 & & & 10 & & & & \\
\hline & Foram reformuladas, mas não estão em uso - Nota 5 & & & & & & & & & \\
\hline & $\begin{array}{l}\text { Foram desenvolvidas após a finalização do programa - } \\
\text { Nota } 10\end{array}$ & & & & & & & & & 10 \\
\hline & Nunca foram desenvolvidas - Nota 0 & & & & & & & & & \\
\hline \multirow{6}{*}{ 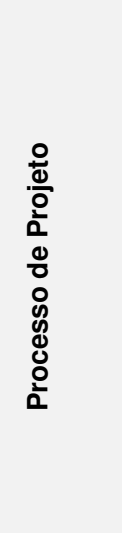 } & Foram mantidas e estão em uso - Nota 7 & & & & & & & 7 & & \\
\hline & Foram mantidas, mas não são utilizadas - Nota 4 & & & & & & & & & \\
\hline & Foram reformuladas e estão em uso - Nota 10 & 10 & 10 & & & 10 & & & & 10 \\
\hline & Foram reformuladas, mas não estão em uso - Nota 5 & & & & & & & & & \\
\hline & $\begin{array}{l}\text { Foram desenvolvidas após a finalização do programa - } \\
\text { Nota } 10\end{array}$ & & & & & & & & & \\
\hline & Nunca foram desenvolvidas - Nota 0 & & & & & & & & & \\
\hline \multirow{6}{*}{ 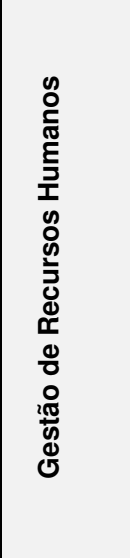 } & Foram mantidas e estão em uso - Nota 7 & & 7 & & & & & & & \\
\hline & Foram mantidas, mas não são utilizadas - Nota 4 & & & & & & & & & \\
\hline & Foram reformuladas e estão em uso - Nota 10 & & & & & 10 & & 10 & & \\
\hline & Foram reformuladas, mas não estão em uso - Nota 5 & & & & & & & & & \\
\hline & $\begin{array}{l}\text { Foram desenvolvidas após a finalização do programa - } \\
\text { Nota } 10\end{array}$ & & & & & & & & & \\
\hline & Nunca foram desenvolvidas - Nota 0 & 0 & & & & & & & & 0 \\
\hline \multirow{4}{*}{ 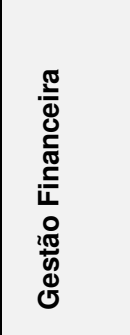 } & Foram mantidas e estão em uso - Nota 7 & & 7 & & & & & 7 & & \\
\hline & Foram mantidas, mas não são utilizadas - Nota 4 & & & & & & & & & \\
\hline & Foram reformuladas e estão em uso - Nota 10 & 10 & & & & 10 & & & & \\
\hline & Foram reformuladas, mas não estão em uso - Nota 5 & & & & & & & & & \\
\hline
\end{tabular}




\begin{tabular}{|c|c|c|c|c|c|c|}
\hline & $\begin{array}{l}\text { Foram desenvolvidas após a finalização do programa } \\
\text { e estão em uso Nota } 10\end{array}$ & & & & & \\
\hline & Nunca foram desenvolvidas - Nota 0 & & & & & 0 \\
\hline \multirow{6}{*}{ 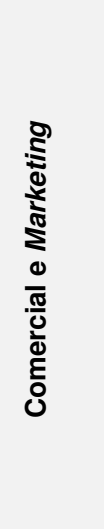 } & Foram mantidas e estão em uso - Nota 7 & & & & 7 & \\
\hline & Foram mantidas, mas não são utilizadas - Nota 4 & & & & & \\
\hline & Foram reformuladas e estão em uso - Nota 10 & & 10 & 10 & & \\
\hline & Foram reformuladas, mas não estão em uso - Nota 5 & 5 & & & & 5 \\
\hline & $\begin{array}{l}\text { Foram desenvolvidas após a finalização do programa } \\
\text { e estão em uso Nota } 10\end{array}$ & & & & & \\
\hline & Nunca foram desenvolvidas - Nota 0 & & & & & \\
\hline \multirow{6}{*}{ 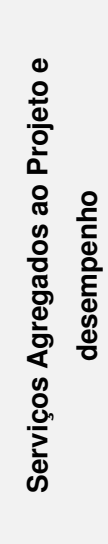 } & Foram mantidas e estão em uso - Nota 7 & & & & & \\
\hline & Foram mantidas, mas não são utilizadas - Nota 4 & & 4 & & 4 & \\
\hline & Foram reformuladas e estão em uso - Nota 10 & & & & & \\
\hline & Foram reformuladas, mas não estão em uso - Nota 5 & & & 5 & & \\
\hline & $\begin{array}{l}\text { Foram desenvolvidas após a finalização do programa } \\
\text { e estão em uso Nota } 10\end{array}$ & 10 & & & & 10 \\
\hline & Nunca foram desenvolvidas - Nota 0 & & & & & \\
\hline \multirow{6}{*}{ 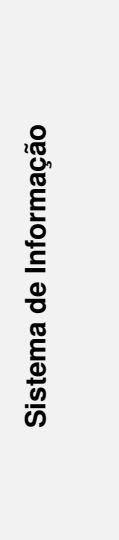 } & Foram mantidas e estão em uso - Nota 7 & & & & 7 & \\
\hline & Foram mantidas, mas não são utilizadas - Nota 4 & & & 4 & & \\
\hline & Foram reformuladas e estão em uso - Nota 10 & 10 & 10 & & & \\
\hline & Foram reformuladas, mas não estão em uso - Nota 5 & & & & & \\
\hline & $\begin{array}{l}\text { Foram desenvolvidas após a finalização do programa } \\
\text { e estão em uso - Nota } 10\end{array}$ & & & & & 10 \\
\hline & Nunca foram desenvolvidas - Nota 0 & & & & & \\
\hline & Notas & 55 & 58 & 59 & 49 & 45 \\
\hline
\end{tabular}

Somatória das Notas de todas as empresas:266 Nota média para o Grupo : 53,20

Escala de desempenho para a continuidade do desenvolvimento gerencial referente a cada um dos elementos de gestão

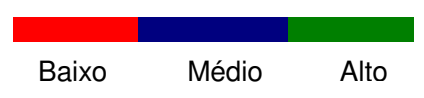




\begin{tabular}{|c|c|c|c|c|c|c|c|}
\hline \multirow{2}{*}{ Tópico } & \multirow{2}{*}{ Aspecto questionado } & \multicolumn{6}{|c|}{ Empresas } \\
\hline & & $\mathbf{J}$ & $\mathbf{K}$ & $\mathbf{L}$ & M & $\mathbf{N}$ & 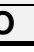 \\
\hline \multirow{6}{*}{ 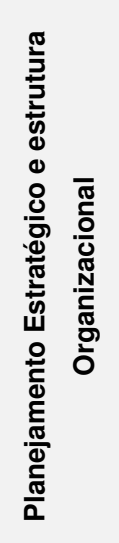 } & Foram mantidas e estão em uso - Nota 7 & & 7 & & & & \\
\hline & Foram mantidas, mas não são utilizadas - Nota 4 & & & & & & \\
\hline & Foram reformuladas e estão em uso - Nota 10 & 10 & & & 10 & 10 & \\
\hline & Foram reformuladas, mas não estão em uso - Nota 5 & & & & & & \\
\hline & $\begin{array}{l}\text { Foram desenvolvidas após a finalização do programa e } \\
\text { estão em uso Nota } 10\end{array}$ & & & & & & \\
\hline & Nunca foram desenvolvidas - Nota 0 & & & & & & \\
\hline \multirow{6}{*}{ 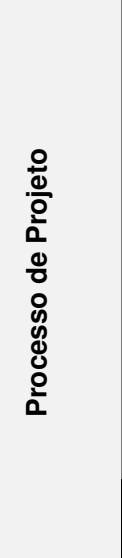 } & Foram mantidas e estão em uso - Nota 7 & & & & & 7 & \\
\hline & Foram mantidas, mas não são utilizadas - Nota 4 & & & & & & \\
\hline & Foram reformuladas e estão em uso - Nota 10 & 10 & 10 & & 10 & & \\
\hline & Foram reformuladas, mas não estão em uso - Nota 5 & & & & & & \\
\hline & $\begin{array}{l}\text { Foram desenvolvidas após a finalização do programa e } \\
\text { estão em uso Nota } 10\end{array}$ & & & & & & \\
\hline & Nunca foram desenvolvidas - Nota 0 & & & & & & \\
\hline \multirow{6}{*}{ 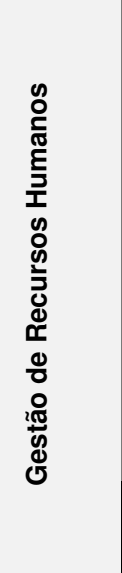 } & Foram mantidas e estão em uso - Nota 7 & & & & & 7 & \\
\hline & Foram mantidas, mas não são utilizadas - Nota 4 & 4 & & & & & \\
\hline & Foram reformuladas e estão em uso - Nota 10 & & 10 & & & & \\
\hline & Foram reformuladas, mas não estão em uso - Nota 5 & & & & & & \\
\hline & $\begin{array}{l}\text { Foram desenvolvidas após a finalização do programa e } \\
\text { estão em uso Nota } 10\end{array}$ & & & & 10 & & \\
\hline & Nunca foram desenvolvidas - Nota 0 & & & & & & \\
\hline \multirow{4}{*}{ 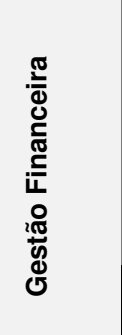 } & Foram mantidas e estão em uso - Nota 7 & 7 & 7 & & 7 & 7 & \\
\hline & Foram mantidas, mas não são utilizadas - Nota 4 & & & & & & \\
\hline & Foram reformuladas e estão em uso - Nota 10 & & & & & & \\
\hline & Foram reformuladas, mas não estão em uso - Nota 5 & & & & & & \\
\hline
\end{tabular}




\begin{tabular}{|c|c|c|c|c|c|}
\hline & $\begin{array}{l}\text { Foram desenvolvidas após a finalização do programa e } \\
\text { estão em uso Nota } 10\end{array}$ & & & & \\
\hline & Nunca foram desenvolvidas - Nota 0 & & & & \\
\hline \multirow{6}{*}{ 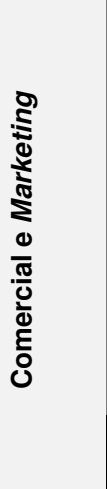 } & Foram mantidas e estão em uso - Nota 7 & 7 & & & 7 \\
\hline & Foram mantidas, mas não são utilizadas - Nota 4 & & & & \\
\hline & Foram reformuladas e estão em uso - Nota 10 & & 10 & 10 & \\
\hline & Foram reformuladas, mas não estão em uso - Nota 5 & & & & \\
\hline & $\begin{array}{l}\text { Foram desenvolvidas após a finalização do programa e } \\
\text { estão em uso Nota } 10\end{array}$ & & & & \\
\hline & Nunca foram desenvolvidas - Nota 0 & & & & \\
\hline \multirow{6}{*}{ 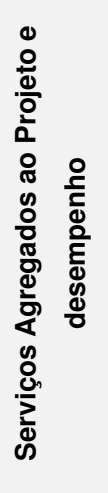 } & Foram mantidas e estão em uso - Nota 7 & & & & \\
\hline & Foram mantidas, mas não são utilizadas - Nota 4 & & & & \\
\hline & Foram reformuladas e estão em uso - Nota 10 & & & & \\
\hline & Foram reformuladas, mas não estão em uso - Nota 5 & & & & \\
\hline & $\begin{array}{l}\text { Foram desenvolvidas após a finalização do programa e } \\
\text { estão em uso Nota } 10\end{array}$ & 10 & 10 & 10 & 10 \\
\hline & Nunca foram desenvolvidas - Nota 0 & & & & \\
\hline \multirow{6}{*}{ 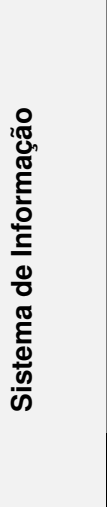 } & Foram mantidas e estão em uso - Nota 7 & & & & 7 \\
\hline & Foram mantidas, mas não são utilizadas - Nota 4 & & & & \\
\hline & Foram reformuladas e estão em uso - Nota 10 & 10 & 10 & 10 & \\
\hline & Foram reformuladas, mas não estão em uso - Nota 5 & & & & \\
\hline & $\begin{array}{l}\text { Foram desenvolvidas após a finalização do programa e } \\
\text { estão em uso - Nota } 10\end{array}$ & & & & \\
\hline & Nunca foram desenvolvidas - Nota 0 & & & & \\
\hline & Notas & 58 & 64 & 67 & 55 \\
\hline
\end{tabular}

Somatória das Notas de todas as empresas:244 Nota média para o Grupo : 61

Escala de desempenho para a continuidade do desenvolvimento gerencial referente a cada um dos elementos de gestão

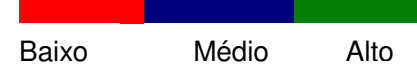


Partindo do princípio de que gestão consiste em um processo contínuo de planejamento, operacionalização, controle e análise crítica, foi atribuída a escala de desempenho referente à continuidade de desenvolvimento gerencial de cada um dos módulos de gestão por parte das empresas.

O alto desempenho, nota 10 , foi atribuído às situações nas quais as ferramentas e procedimentos foram reformuladas ou que foram desenvolvidos mesmo após o término do programa, demonstrando claramente que as etapas de controle e análise crítica do ciclo de gestão foram realizadas.

O médio desempenho, notas 7 e 5, foi atribuído às situações em que as ferramentas e procedimentos desenvolvidos durante o programa foram mantidos, e o baixo desempenho, notas 4 e 0 , foi atribuído às situações nas quais as ferramentas e procedimentos não foram desenvolvidos.

As tabelas possibilitam a análise quanto ao desempenho geral das empresas, e podem indicar possíveis problemas na proposição das tarefas, principalmente quanto a pertinência e a dificuldade.

Quanto ao desempenho geral das empresas: no primeiro grupo, verifica-se melhor desempenho para as empresas "A", "B" e "E", cujas notas somadas foram 55, 58 e 59 respectivamente e desempenho médio para as empresas "G" e "l"; cujas notas somadas foram 49 e 45 respectivamente. Para o segundo grupo, o melhor desempenho destaca-se nas empresas "K" e "M" ", cujas notas somadas foram 64 , e 67 respectivamente, e médio desempenho nas empresas "J" e "N". ", cujas notas somadas foram 58 e 55 respectivamente

O baixo desempenho quanto a realização das tarefas propostas nos módulos serviços agregados e desempenho foi geral tanto no PDGEP 1 quanto no PDGEP 2.

Para os outros módulos, as Tabelas 3.10 e 3.11 ilustram a predominância entre os desempenhos médios e altos, ou seja, as empresas desenvolveram os procedimentos e as ferramentas mesmo após o término dos programas. Tal fato demonstra claramente a pertinência das tarefas propostas.

Quando comparados o PDGEP 1 e 2, verifica-se que a nota média do segundo grupo, 61, é maior do que a do primeiro grupo, 55,20, demostrando sensível evolução do PDGEP 2 em relação ao PDGEP 1. 
Contudo, a não realização das tarefas e, portanto, a não implementação total do modelo, não significam que as empresas não se desenvolveram, pois o desenvolvimento gerencial não é um processo cuja maior parte dos resultados são obtidos imediatamente, e as empresas em geral, mesmo as de pequeno porte, são sistemas complexos e, dessa forma, sua organização - ou até mesmo sua reestruturação, não pode ser avaliada num período de tempo tão curto quanto o utilizado no PDGEP 1 e PDGEP 2.

Quando questionadas sobre os efeitos do programa em suas empresas, estas destacaram a possibilidade de discussão e reflexão sobre problemas comuns e interação como o principal benefício na participação do Programa de Desenvolvimento Gerencial.

Outro benefício ressaltado por grande parte das empresas relaciona-se à organização do processo de projeto, pois trata-se de um aspecto cujos benefícios, em função da intervenção visando a organização e controle, pôde ser sentido imediatamente.

No próximo capítulo são propostas recomendações, cujo objetivo é facilitar a aplicação dos conceitos de gestão referentes aos diversos módulos que compõem o modelo proposto por Oliveira (2005). 


\section{PROPOSIÇÃO DE RECOMENDAÇÕES PARA FACILITAR A APLICAÇÃO DOS CONCEITOS DE GESTÃO ÀS EMPRESAS DE PROJETO}

\subsection{Recomendações para aplicação dos conceitos sobre estrutura organizacional às empresas de projeto de edifícios}

Partindo da abordagem de Mintzberg (2003) sobre os mecanismos de coordenação, verifica-se que nas empresas de projeto ocorre a padronização das habilidades, pois praticamente todo o corpo funcional é formado por arquitetos ou engenheiros especialistas em sua área de atuação. Por outro lado, por mais que as empresas padronizem o processo de projeto com o objetivo de uniformizar a forma de trabalhar e o tratamento das informações, é muito difícil obter um padrão de produto e de processo, já que todos os projetos são diferentes uns dos outros. Por serem de pequeno porte, na maior parte destas empresas ocorre a predominância da comunicação informal e o controle do trabalho, e suas operações são de responsabilidade de quem as realiza.

Analisando-se as partes das empresas de projeto, ainda partindo da abordagem de Mintzberg (2003), observa-se que as empresas nascem do núcleo operacional, no qual se encontram todos os profissionais especialistas que desenvolvem os projetos, e normalmente são estes mesmos profissionais que desenvolvem padrões quanto à realização do processo de projeto.

A cúpula estratégica é ocupada pelo profissional titular da empresa, que detém todas as decisões estratégicas sob seu domínio. A unidade de apoio, na maior parte das empresas desse tipo, é formada por uma secretária (que auxilia o profissional titular na realização das tarefas administrativas e controles financeiros), por um escritório de contabilidade terceirizado (que auxilia a empresa em relação às questões fiscais), e por uma empresa especializada em informática (que auxilia a empresa em questões básicas relacionadas ao seu sistema e equipamentos).

Nessas empresas ocorre a priorização dos processos técnicos, predominando a visão equivocada de que a gestão administrativa, financeira, de pessoas e comercial inviabilizam a operacionalização do processo de projeto. 
Sobre o desenvolvimento da estrutura organizacional, partindo da escolha da forma alinhada com a estratégia de atuação da empresa no sentido de viabilizar o sistema técnico, a estruturação deve levar em consideração os seguintes aspectos:

- As empresas de projeto normalmente trabalham com, pelo menos, dois produtos dentro da especialidade de projetos (consultoria direcionada à aprovação legal de projetos, coordenação ou gerenciamento; desenvolvimento de projetos executivos, aprovação de projetos legais,etc.). A estrutura deve viabilizar o controle e a gestão referentes à alocação dos profissionais e/ou equipes em projetos diversos.

- Os projetos, apesar de possuírem características bastante semelhantes, são únicos, e cada qual necessita de análise técnica e definição de recursos personalizados.

- As empresas desenvolvem simultaneamente vários projetos.

- Os projetos possuem um ciclo de vida definido dentro das empresas; portanto, deve-se ter em mente a flexibilidade proporcionada em cada tipo de estrutura no momento da sua escolha.

- As áreas administrativas (comercial, recursos humanos, financeiro, infraestrutura) desenvolvem atividades que dizem respeito a todos os projetos. Por se tratarem, na maior parte dos casos, de pequenas e médias empresas, não são destacados profissionais dessas áreas para atuarem em projetos específicos.

O trabalho de desenvolvimento da estrutura organizacional contempla, além da escolha da forma, o detalhamento das atribuições de responsabilidades de cada área/função e forma(s) de comunicação. Este é um dos principais problemas desse tipo de empresa, pois predomina a filosofia de que todos são responsáveis por tudo, principalmente o profissional titular. Verifica-se que, nesses casos, durante a operacionalização do trabalho e posterior surgimento de problemas a serem resolvidos, a predominância da desorganização e a isenção de responsabilidades por parte de alguns, gerando a sensação de total desconforto na empresa. 
Antes da definição da estrutura organizacional da empresa de projeto com o objetivo de facilitar a reflexão quanto a escolha da estrutura mais adequada à empresa, recomenda-se a elaboração de uma matriz de responsabilidades.

No eixo vertical da matriz devem ser descritas todas as atividades consideradas relevantes pela empresa, organizadas por áreas (projeto, financeiro, recursos humanos, comercial, etc.), e no eixo horizontal devem constar as áreas ou profissionais responsáveis pela operacionalização das atividades.

A primeira matriz a ser elaborada deve retratar a empresa antes da intervenção da organização. Para tanto, deve fornecer a adequada visualização sobre a abrangência das atividades realizadas, distribuição de autoridade e responsabilidade.

Em função das informações fornecidas pela matriz, a empresa deve refletir sobre a melhor forma de organização - estabelecimento e reorganização de áreas ou não, redistribuição de funções, autoridades e definição de responsabilidades.

A partir de tais definições, uma "matriz ideal" deve ser elaborada com o objetivo de retratar a intervenção de organização. A análise da "matriz ideal" subsidiará a definição da estrutura organizacional mais adequada à empresa.

Um organograma formal isoladamente pode não ser a maneira mais eficaz de retratar a organização e distribuição de responsabilidades e de autoridade na empresa de projeto. Contudo, a utilização de ferramentas simplificadas e mais objetivas, a exemplo da matriz de responsabilidades, pode ser a alternativa mais adequada para auxiliar na organização da pequena empresa de projeto e facilitar a escolha da tipologia de estrutura coerente com as características da empresa.

Neste sentido, torna-se necessária, para as empresas de projeto, a consciência de suas limitações, e submeter-se a um processo de adaptação de suas estruturas e forma de trabalho é imperativo, pois flexibilidade organizacional corresponde à capacidade de reação frente a um mercado extremamente competitivo e com nível de exigência crescente, se comparado às épocas anteriores. 


\subsection{Recomendações para aplicação dos conceitos de gestão de projetos à gestão do processo de projeto de edifícios}

Considerando que o processo de projeto viabiliza a existência de uma empresa de projetos, torna-se fundamental que os seus gestores compreendam a sua complexidade, de forma a planejá-lo e organizá-lo, capacitando a empresa a atender vários clientes simultaneamente e a trabalhar de forma colaborativa com todos os agentes que compõem as diversas equipes multidisciplinares dos projetos de edifícios.

Entende-se que a primeira etapa para a organização do processo produtivo de uma empresa de projeto é a caracterização dos diversos produtos oferecidos aos seus clientes, de forma a identificar as suas peculiaridades e cada uma das suas etapas de trabalho.

À princípio, o produto ou serviço oferecido por essas empresas é, genericamente, denominado de projeto; no entanto, verifica-se uma gama bastante variada de subprodutos. Cada um desses subprodutos apresenta, desde a sua contratação, durante a produção e até posterior entrega, características muito distintas uns dos outros.

Após a identificação e caracterização dos subprodutos e serviços oferecidos, partindo dos princípios de gestão (planejar, realizar, controlar e retroalimentar), recomenda-se aos gestores da empresa estabelecer como ocorrerá a organização dos diversos processos identificados, seja através da definição de macrofluxos, procedimentos operacionais, diretrizes genéricas para a realização dos trabalhos ou até mesmo controle através de ferramentas, tais como listas de verificação.

Os gestores devem estar atentos ao fato de que a organização de cada um dos processos de trabalho não os isenta de repensá-los a cada nova contratação, pois cada projeto ou serviço prestado pelas empresas de projeto de edifícios possui características muito particulares, tornando-os únicos. 
Ao ser contratada para um novo trabalho de projeto, sugere-se que a empresa elabore um plano de atividades a ser utilizado como referência para a gestão das etapas de trabalho.

Baseada nos princípios da gestão de projetos, a Tabela 4.1 sugere um conjunto de atividades para a confecção do plano proposto. Além das análises quanto a complexidade técnica do projeto, da sequência de trabalho do projeto e interfaces com outras disciplinas, devem ser definidos no plano a forma de comunicação, definição de responsabilidades, previsão de recursos (pessoas, tecnologia, financeiros, tempo, etc.) e critérios para controle do processo tanto do ponto de vista operacional quanto da qualidade. 


\begin{tabular}{|c|c|c|}
\hline Topico & Atividade & Plano Gerado \\
\hline Escopo & $\begin{array}{l}\text { - Definição do escopo de projeto a partir das } \\
\text { diretrizes estabelecidas na contratação, } \\
\text { das informações fornecidas pelo cliente } \\
\text { através de folders de vendas, registros } \\
\text { oficiais e da relação de trabalho junto aos } \\
\text { demais participantes da equipe } \\
\text { multidisciplinar. }\end{array}$ & $\begin{array}{ll}\text { Escopo do Projeto } \\
\text { Contratado. }\end{array}$ \\
\hline Equipe & $\begin{array}{l}\text { - Definição da Equipe: coordenador e } \\
\text { colaboradores. } \\
\text { Diagnosticar a necessidade de treinamento } \\
\text { e/ou aperfeiçoamento da formação dos } \\
\text { componentes da equipe de trabalho, em } \\
\text { função das características do projeto. }\end{array}$ & $\begin{array}{l}\text { - Matriz de responsabilidades } \\
\text { iniciais. } \\
\text { - Plano de Treinamento. }\end{array}$ \\
\hline $\begin{array}{l}\text { Estrutura do } \\
\text { Projeto }\end{array}$ & $\begin{array}{l}\text { - Identificação das diversas etapas de } \\
\text { trabalho durante o projeto. }\end{array}$ & $\begin{array}{l}\text { - EAP (estrutura analítica do } \\
\text { projeto). } \\
\text { - Matriz de responsabilidades. }\end{array}$ \\
\hline Tempo & $\begin{array}{l}\text { Em função da equipe, das diversas etapas } \\
\text { de trabalho identificadas na estrutura do } \\
\text { projeto, das necessidades do cliente e interface } \\
\text { com demais disciplinas de projeto, deve ser } \\
\text { previsto o tempo necessário para o } \\
\text { desenvolvimento de cada uma das etapas de } \\
\text { trabalho. }\end{array}$ & - Cronograma do Projeto. \\
\hline $\begin{array}{l}\text { Equipamentos e } \\
\text { Tecnologia }\end{array}$ & $\begin{array}{l}\text { Em função das características do projeto e } \\
\text { das diretrizes de contratação do projeto, deve } \\
\text { ser avaliada, por parte da empresa, a } \\
\text { necessidade ou não de aquisição de } \\
\text { equipamentos e/ou tecnologia. }\end{array}$ & $\begin{array}{l}\text { Diretrizes para aquisição de } \\
\text { equipamentos e/ou } \\
\text { tecnologia (orçamentos, } \\
\text { análise e equalização de } \\
\text { propostas, contratos). }\end{array}$ \\
\hline Comunicação & $\begin{array}{l}\text { Definição da forma de comunicação na } \\
\text { empresa junto ao cliente e demais projetistas } \\
\text { da equipe multidisciplinar de projeto, bem } \\
\text { como diretrizes quanto a transformação da } \\
\text { comunicação em dados de projeto. } \\
\end{array}$ & $\begin{array}{l}\text { - Plano de Comunicação e } \\
\text { Informação: diário de } \\
\text { projeto, histórico de projeto, } \\
\text { procedimento quanto ao } \\
\text { recebimento, }\end{array}$ \\
\hline $\begin{array}{l}\text { Tratamento da } \\
\text { Informação }\end{array}$ & $\begin{array}{l}\text { Em função das diretrizes do cliente e } \\
\text { práticas usuais da empresa, definiçães em } \\
\text { relação à captação, tratamento, organização e } \\
\text { acesso à informação. } \\
\text { Continua na primeira }\end{array}$ & $\begin{array}{l}\text { encaminhamento, } \\
\text { organização e acesso à } \\
\text { informação. } \\
\text { - Matriz de responsabilidades. }\end{array}$ \\
\hline
\end{tabular}


Tabela 4.1: Recomendações para elaboração de uma plano geral para gestão do processo de projeto

\begin{tabular}{|c|c|c|}
\hline Topico & Atividade & Plano Gerado \\
\hline Orçamento & $\begin{array}{l}\text { Em função dos planos propostos quanto ao } \\
\text { escopo, equipe, tempo, aquisições, } \\
\text { comunicação e controle da qualidade, devem } \\
\text { ser previstos os custos de projeto em cada } \\
\text { uma das etapas. }\end{array}$ & Planilha Orçamentária. \\
\hline Qualidade & $\begin{array}{l}\text { Produto Edifício: obtenção dos critérios de } \\
\text { desempenho, construtibilidade, habitabilidade e } \\
\text { qualidade do produto edifício em função do } \\
\text { requisitos declarados e não declarados do } \\
\text { cliente, construtor, usuário e sociedade, bem } \\
\text { como legislações e normas técnicas. Todas } \\
\text { essas informações devem ser transformadas } \\
\text { em especificações a serem desenvolvidas } \\
\text { durante o processo de projeto. } \\
\text { Processo de projeto: definição de critérios } \\
\text { da qualidade para acompanhamento do } \\
\text { processo de projeto (tempo, retrabalho, } \\
\text { soluções projetuais, custo, comunicação e } \\
\text { fluxo de informações). }\end{array}$ & \multirow[t]{3}{*}{$\begin{array}{l}\text { Plano da qualidade do } \\
\text { projeto. }\end{array}$} \\
\hline $\begin{array}{l}\text { Controle e } \\
\text { Desempenho }\end{array}$ & $\begin{array}{l}\text { Definição das ferramentas pertinentes ao } \\
\text { controle da elaboração do processo de projeto, } \\
\text { bem como indicadores de desempenho } \\
\text { necessários ao acompanhamento dos planos } \\
\text { definidos em relação ao tempo, retrabalho, } \\
\text { soluções projetuais, custo, comunicação e } \\
\text { fluxo de informacões. }\end{array}$ & \\
\hline $\begin{array}{c}\text { Retroalimentaçã } \\
0\end{array}$ & $\begin{array}{l}\text { Definição da forma de obtenção de } \\
\text { informações referentes à qualidade das } \\
\text { soluções projetuais, análise dos planos e } \\
\text { controles utilizados durante o processo de } \\
\text { projeto, de forma a transformar as experiências } \\
\text { vividas em conhecimento para a empresa. }\end{array}$ & \\
\hline
\end{tabular}

\subsection{Recomendações para a aplicação dos conceitos sobre planejamento estratégico às empresas de projeto de edifícios}

O desenvolvimento da estratégia de uma empresa deve ser embasado pelo autoconhecimento e pela análise do ambiente no qual está inserido. Para a análise a ser realizada de forma genérica para as empresas de projeto, será utilizado o modelo de cadeia de valores e delineamento do ambiente competitivo proposto por Porter (1989). 
Partindo desse modelo de cadeia de valores aplicado às empresas de projetos, conforme demonstra a Figura 4.1, as atividades primárias são aquelas inerentes ao processo de projeto, ou seja, a atividade comercial na qual se inicia o processo de projeto, a própria atividade de desenvolvimento de projeto e consultorias, e a atividade de assistência técnica. As atividades que subsidiam a execução da tarefa principal, o processo de projeto, são o sistema de informações, gestão de pessoas, gestão de marketing e gestão financeira.

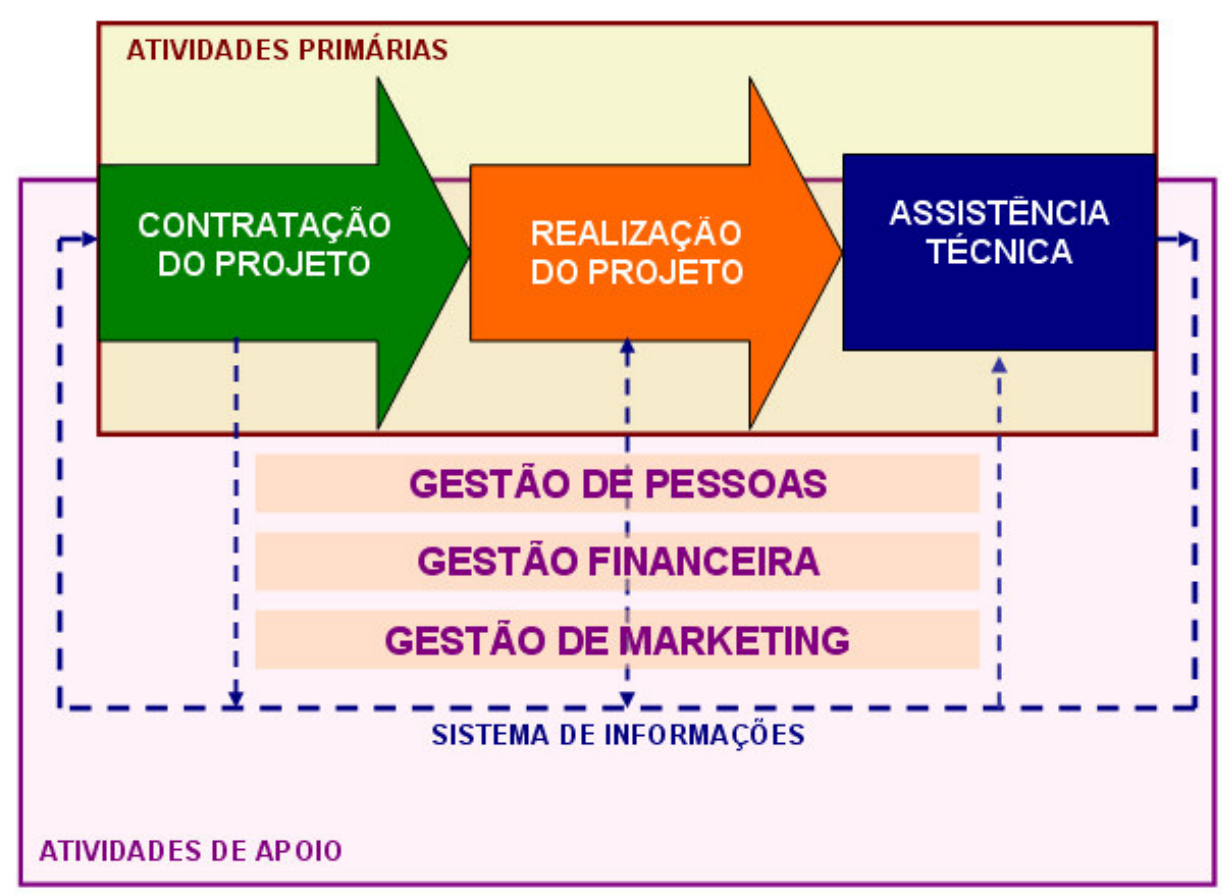

Figura 4.1 - Cadeia de valores genérica para empresas de projeto composta por atividades primárias e atividades de apoio, de acordo com os conceitos estabelecidos por Porter (2004)

O sistema de informações deve ser alimentado através dos indicadores de desempenho e informações relevantes procedentes dos contratantes, usuários de projeto e profissionais envolvidos no seu desenvolvimento. A atividade relacionada à gestão de pessoas é elemento fundamental para a realização da atividade de projeto, já que seu principal insumo é a informação processada através dos profissionais que nela atuam. A gestão de marketing possui como objetivo promover a atratividade do(s) produto(s) oferecidos pela empresa, encontrar nichos de mercado e potenciais clientes, além de delinear novos negócios e produtos para empresa. Finalmente a gestão financeira, responsável pela organização dos 
recursos financeiros da empresa, subsidia o gestor principal com informações para a tomada de decisões estratégicas para a empresa.

Quanto à análise externa, as empresas de projeto atuam num ambiente caracterizado por intensa competição, sensível às oscilações de produção de todos os outros setores industriais do país, dificuldades econômicas, mudanças tecnológicas, incertezas sobre políticas governamentais, fatores estes que podem ameaçar ou exercer influência sobre a sua posição competitiva no mercado.

Isto posto, para que a definição da estratégia aconteça de forma adequada, é fundamental que a empresa conheça o ambiente no qual está inserida e a posição que nele ocupa. A maior parte desses fatores são incontroláveis, mas isso não significa que devam ser negligenciados e utilizados como justificativa para um desempenho abaixo do esperado.

De acordo com Porter (2004), para delineamento do ambiente competitivo devem ser identificados como fornecedores aqueles que podem influenciar a posição competitiva das empresas de projeto, ou seja, as escolas e universidades formadoras dos profissionais que atuarão nas empresas e os fornecedores de tecnologia, pois o principal recurso desta atividade é informação processada através do conhecimento dos Técnicos, Engenheiros e Arquitetos.

Os entrantes potenciais são as novas empresas de projeto que surgem com facilidade, já que as barreiras de entrada são facilmente transpostas no segmento de projeto. Os clientes exercem forte influência na posição competitiva das empresas de projeto, pois são eles os agentes que estabelecem os preços de mercado para os projetos, e algumas contratações são estratégicas do ponto de vista de projeção de marketing das empresas, podendo projetá-las de forma bastante significativa no mercado.

Os possíveis substitutos para a atividade de projeto podem ser os fornecedores que incluem no pacote de fornecimento de seus produtos o serviço de desenvolvimento do projeto, a exemplo dos fornecedores de estruturas metálicas, fornecedores de estruturas pré-fabricadas em concreto armado, empreitadas de vedações verticais, etc., ou novas especialidades que surgem em função da subdivisão da atividade, a exemplo dos projetistas de garagens pois, em princípio, esta responsabilidade da 
atividade de arquitetura e novas especialidade projetuais que surgem em função de inovações tecnológicas ou em função da necessidade de racionalização da produção (exemplos: projetistas de vedações verticais, projetistas de fôrmas, etc).

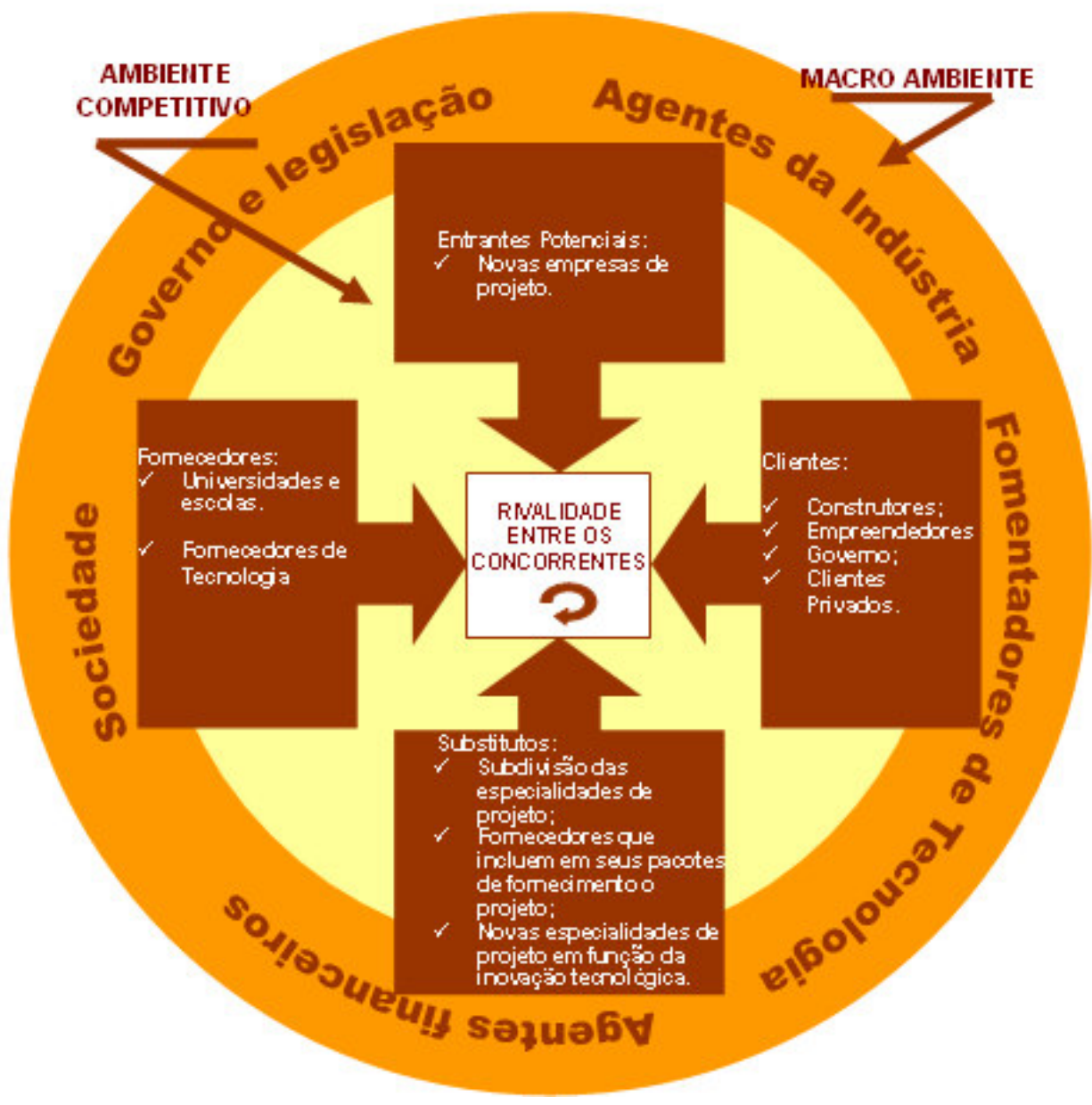

Figura 4.2 - Macroambiente e ambiente competitivo no qual as empresas de projeto estão imersas

Analisando o ambiente competitivo no qual estão inseridas as empresas de projeto (Figura 4.2), percebe-se que elas estão imersas num setor fragmentado. Esta é a denominação estabelecida por Porter (2004) para setores nos quais um alto número de empresas de pequeno e médio porte atuam sem que nenhuma possua parcela de mercado significativa que possa influenciar fortemente o resultado do setor. Este setor pode ser assim caracterizado porque as barreiras de entrada são pouco significativas, as empresas são caracterizadas pela ausência de economia de escala expressiva, existe dificuldade em padronizar ou estabelecer uma rotina de trabalho; se comparados os custos de operação entre empresas, verifica-se que são muito 
parecidos, as flutuações de vendas são irregulares e dependem parcialmente de políticas governamentais de incentivo para a indústria da construção civil.

Em função das empresas de projeto serem em maior parte de pequeno porte, é remota a possibilidade exercerem algum tipo de influência sobre os agentes do seu ambiente (fornecedores, entrantes potenciais, clientes e possíveis substitutos), no entanto, é importante que as empresas de projeto conheçam tais agentes e analisem como cada um deles pode influenciar a sua atuação e competitividade.

De acordo com a revisão bibliográfica realizada, no tocante à operacionalização do processo de planejamento, recomenda-se que os objetivos estratégicos das empresas de projeto sejam estabelecidos em função de análise interna criteriosa e análise do mercado no qual está inserida, compatíveis com a sua realidade e que sejam acompanhados através de uma sistemática de controle e avaliação compatível com suas limitações de recursos humanos e financeiros através de um plano de ação que, por sua vez, deve ser elaborado dentro de um horizonte estratégico adequado também às características da empresa e do setor, salientando-se prazos e responsabilidades.

Quanto à divisão do planejamento proposta pela maioria dos autores - estratégico, tático e operacional, a sua implementação é discutível para o caso das empresas de projeto de edifícios, pois como já colocado, são em maior parte empresas de pequeno porte. O nível tático dessas empresas sobrepõe-se ao nível estratégico e operacional, ou seja, existe uma divisão clara entre a cúpula estratégica e o nível operacional das empresas; no entanto, o mesmo não acontece com o nível tático.

\subsection{Recomendações para aplicação dos conceitos sobre gestão financeira às empresas de projeto de edifícios}

Conforme verificado na revisão bibliográfica, o sistema de gestão financeira da empresa de projeto deve ser estruturado de acordo com seu modelo de práticas de decisões. 
Normalmente a gestão financeira desse tipo de empresa é de responsabilidade do profissional titular, auxiliado externamente por uma empresa de contabilidade, que tem por objetivo de manter atualizados e controlados os pagamentos de impostos e demonstrativos oficiais. Internamente, um assistente ou secretária normalmente auxiliam o titular na alimentação de seus controles.

No entanto, observa-se precariedade em tais controles e demonstrativos na maior parte das empresas de projeto, o que leva, na maior parte dos casos, ao desconhecimento, por parte dos seus gestores, da saúde financeira da empresa, bem como das possibilidades de expansão e investimento.

Um sistema de controle e gestão financeira para uma pequena empresa não é sinônimo de um sistema complexo, sofisticado e automatizado. Mesmo que o seja, para a sua elaboração deve-se partir das reais necessidades de controle da empresa de projeto. Por outro lado, tal sistema também pode ser estruturado a partir de planilhas simples, desde que sejam pensados e analisados previamente os parâmetros de controle necessários.

De acordo com Oliveira (2005), o primeiro passo para estruturação de tal sistema é a organização dos custos e despesas em diretas, indiretas, fixas ou variáveis, através de um plano de contas que servirá como base para os controles propostos posteriormente.

Conforme verificado na revisão bibliográfica, dentro da sistemática de organização é fundamental a definição do sistema de acumulação de custos. Nesse sentido, recomenda-se para as empresas de projeto o sistema por ordem de projeto, que possibilita o acompanhamento do histórico financeiro de cada um dos projetos.

Ainda com enfoque na definição e organização do sistema, recomenda-se à empresa de projeto o estabelecimento de rotinas relacionadas à mensuração dos seus custos operacionais, como por exemplo, as horas despendidas em cada projeto para cada um dos níveis hierárquicos envolvidos.

Tal controle possibilita para a empresa de projeto, além da alimentação do sistema de gestão financeiro, a obtenção de parâmetros para precificação e posterior 
negociação de projetos, e a análise da possibilidade de investimentos em tecnologia e formação, entre outros.

Assim como o controle de horas, a empresa de projeto deve preocupar-se em definir rotinas referentes ao controle de contas à pagar, à receber e folha de pagamento, pois tais registros e controles devem alimentar os demonstrativos contábeis e financeiros.

Com relação aos demonstrativos financeiros: Balanço Patrimonial; Resultado do Exercício e Fluxo de Caixa, é de conhecimento que as empresas, em função dos controles contábeis, são obrigadas a desenvolve-los por força da obrigatoriedade da lei de manter em ordem a documentação dos ativos, dívidas e negociações com terceiros. No entanto, verifica-se uma verdadeira aversão a tais controles por parte de algumas empresas de projeto, provavelmente ocasionada pelo desconhecimento das peculiaridades e finalidades de cada um deles.

Já que as empresas de projeto são obrigadas a desenvolver tais demonstrativos, porque não elaborá-los de forma que possam possibilitar a análise e a tomada de decisão?

Toma-se como exemplo sobre a importância do correto desenvolvimento dos demonstrativos financeiros das empresas de projeto, o registro e controle adequado dos softwares adquiridos para a atividade projetual, nos balanços patrimoniais.

Verifica-se atualmente no segmento de projeto um alto custo para a aquisição das suas licenças, as quais são denominadas, do ponto de vista da contabilidade, de ativos. Portanto, a elaboração adequada do balanço patrimonial da empresa de projeto, contemplando o registro de softwares e equipamentos em geral, torna-se relevante para o caso de dissoluções de sociedades, além de subsidiar a análise referente ao investimento em tecnologia e ferramentas.

Outra vantagem para o desenvolvimento adequado de tal demonstrativo, além de facilitar análises na tomada de decisão, aplica-se aos casos em que potenciais clientes baseiam a decisão de contratação na capacidade de produção e de recursos tecnológicos da empresa. 
Quanto ao demonstrativo contábil denominado Resultado do Exercício, sua análise possibilita o acompanhamento da saúde financeira da empresa e é fundamental para as empresas cujos lucros são divididos com os colaboradores. O Fluxo de Caixa permite a avaliação da empresa ao longo do tempo, a administração do capital de giro da empresa, e subsidia o planejamento estratégico.

Cada um dos controles citados não deve ser analisados isoladamente. Nesse sentido, a empresa de projeto deve estabelecer qual horizonte é mais adequado para a realização de seu planejamento financeiro, de forma a embasar a tomada de decisão na empresa.

\subsection{Recomendações para aplicação dos conceitos abordados em sistemas de informação e comunicação às empresas de projeto de edifícios}

Para Cragg e Zinatelli (1995), o desenvolvimento de modelos de sistemas de informação negligenciam a realidade e as limitações das pequenas e médias empresas, e existem fatores preponderantes que interferem no adequado desenvolvimento e implementação dos sistemas nessas empresas. Em função da falta de conhecimento sobre 0 assunto, os critérios de contratações para desenvolvimento e aquisições de equipamentos e aplicativos nessas empresas são definidos de forma equivocada. Os autores ainda afirmam que a gestão do sistema de informações é negligenciada pela maior parte das empresas, ficando a cargo de um profissional sem formação específica na área.

Verifica-se que, para a definição eficaz do sistema de informações de uma empresa, é necessária a compreensão da importância da informação na sua atividade-fim e nos processos relacionados à sua gestão. Para a realização desta análise nas empresas de projeto e a compreensão da importância da informação nesse contexto, sugere-se a aplicação do método proposto por Turban; MacLean; Wetherbe (2004), denominado de modelo de planejamento para análise de requisitos da informação. A utilização deste modelo objetiva a identificação da arquitetura geral da informação na empresa e suas necessidades atuais e futuras. $O$ modelo contempla as seguintes etapas: 
1. Definir subsistemas organizacionais subjacentes.

2. Definir e avaliar as necessidades de informação para os subsistemas organizacionais

3. Definir as categorias principais de informação.

4. Desenvolver categorias de informação por subsistema.

Uma vez que a aplicação do referido modelo aos diversos processos da empresa de projeto possibilita a visualização do fluxo geral de informação, é possível, a partir de análise, definirem-se as ferramentas adequadas para a sua captação, armazenamento e disponibilização. No artigo "A importância do sistema de informações para a gestão das empresas de projeto", de Souza e Melhado (2008), estão detalhados os diversos processos de gestão de uma empresa de projetos e o seu fluxo de informação.

Quanto à gestão do conhecimento nas empresas de projeto, predominam alguns fatores que facilitam o processo de aprendizado organizacional. Por serem, em sua maioria, empresas de pequeno e médio porte, a propagação do conhecimento é facilitada. Os projetos são únicos e, portanto, faz parte da rotina de trabalho o aprendizado contínuo durante a sua realização. Outra questão facilitadora do processo de aprendizado nessas empresas é o fato dos trabalhos serem realizados por equipes multidisciplinares, e essa é uma outra oportunidade de captação e aperfeiçoamento do conhecimento.

Por outro lado, o desenvolvimento da cultura de planejamento, gestão e avaliação do conhecimento nessas empresas é necessário pois, apesar de serem inúmeras as vias de entrada de conhecimento, caso não ocorra de forma organizada, a disseminação, a acessibilidade e a possibilidade de transformação do conhecimento em vantagem competitiva tornam-se inviáveis.

As empresas de projeto devem manter uma memória organizacional onde deve estar contido, de forma organizada, todo o conhecimento por elas adquirido. Esta memória deve estar em permanente operação na aquisição e no fornecimento de conhecimento. 
As formas de aquisição de conhecimento para a empresa de projeto ocorrem constantemente em função da realização da atividade projetual, mas todo este conhecimento só será bem aproveitado se forem realizados o planejamento das entradas (identificação das fontes), da gestão do processo (organização das informações a serem transformadas em conhecimento) e da retroalimentação do processo (acessibilidade do conhecimento e fomentação).

\subsection{Recomendações para aplicação dos conceitos abordados sobre gestão comercial e marketing às empresas de projeto de edifícios}

Conforme já destacado neste texto, as empresas de projeto e seus produtos possuem características muito específicas, o que limita a aplicação de ferramentas desenvolvidas em diversas áreas de conhecimento da administração de empresas, mais especificamente do assunto marketing, tratado nesse item do trabalho.

No entanto, o que se verifica através da revisão do assunto é que, para que ocorra eficácia na estratégia de marketing estabelecida pela empresa, é de fundamental importância o delineamento adequado dos produtos a partir da necessidade de um determinado mercado. Nesse sentido, a empresa de projeto deve estabelecer ações a fim de conhecer os seus clientes, suas características, suas necessidades e, principalmente, o que valorizam, bem como a sistemática comercial que viabiliza os relacionamentos.

Assim, tanto as pequenas empresa de projeto quanto as pequenas empresas de outros setores, não fazem uso dos conhecimentos e das ferramentas de marketing por acreditarem que suas características particulares limitam a aplicação. Um dos argumentos utilizados por esses empresários é a escassez de recursos financeiros para investimento nas ações e estratégias de marketing. No entanto, se analisadas tais características, verifica-se que as mesmas podem ser utilizadas à favor das empresas nas relações comerciais, ao contrário do que acreditam os microempresários.

Normalmente, existe grande proximidade entre o profissional titular da empresa de projeto e o responsável pela tomada de decisão quanto a contratação ou não do 
serviço de projeto. Tal proximidade permite à empresa de projeto conhecer melhor o seu mercado e as necessidades dos contratantes, bem como identificar e aproveitar as suas oportunidades.

Outra vantagem das empresas de projeto está relacionada ao porte da empresa. Por tratarem-se de pequenas empresas, em sua grande maioria, possuem maior versatilidade para atenderem às solicitações mercadológicas de médio e longo prazo, e flexibilidade para adaptarem-se às necessidades imediatas de seus clientes, prestarem serviços personalizados e cultivarem as relações de confiança junto aos contratantes e demais profissionais envolvidos no projeto.

Conforme citado anteriormente com relação à caracterização da relação comercial entre a empresa de projeto, nota-se que projetos de edifícios não são produtos de massa vendidos em grande escala para uma parcela significativa da sociedade. Pelo contrário, trata-se de um serviço com alto grau de intangibilidade, totalmente personalizado e contratado por uma empresa responsável pela definição do produto edifício, que o disponibiliza para o consumidor final.

Sendo assim, a relação comercial estabelecida entre a empresa projetista e o seu contratante é denominada de compra organizacional. Segundo revisão bibliográfica, assim como no mercado de massa, é importante estabelecer as estratégias de marketing em função do conhecimento das peculiaridades do mercado organizacional para o qual a empresa trabalha.

O entendimento do mercado organizacional passa pelos tipos de relacionamentos na contratação de projeto, profissionais envolvidos no processo, critérios dos tomadores de decisão e profissionais que influenciam no processo, bem como quais são os fatores que podem ascender positiva e negativamente à uma contratação.

Outro aspecto relevante no estabelecimento da adequada estratégia de marketing de uma empresa é relacionada ao perfeito delineamento de produtos. No caso das empresas de projeto de edifícios, verifica-se que esse aspecto é negligenciado, pois a empresa trata de forma generalizada o serviço projeto.

A segmentação dos serviços que uma empresa projetista presta pode influenciar positivamente nos diversos processos administrativos e técnicos da empresa. Por 
exemplo, o controle da influência que cada um dos serviços exerce sobre o faturamento da empresa pode direcionar o planejamento de treinamento $\mathrm{e}$ contratação de pessoas, aquisição de ferramentas e equipamentos, estratégia de abordagem junto aos clientes e identificação de vantagem ou desvantagem competitiva junto aos concorrentes.

As relações comerciais entre as empresas de projeto e seus contratantes ocorrem tradicionalmente através da venda pessoal e do marketing caracterizado como direto. No entanto, como já abordado, para que essa estratégia tenha eficácia, é necessário um mínimo de organização por parte da empresa. Tal organização passa pela formalização de um sistema que forneça com facilidade pelo menos as seguintes informações: cadastro dos clientes e perfis; participação de cada um dos seus serviços no mercado; participação de cada um dos serviços e de cada cliente no faturamento da empresa.

Dessa forma, a empresa terá condições de direcionar as ações e esforços quando do estabelecimento do planejamento de marketing, de forma a utilizar adequadamente as estratégias do marketing direto e das vendas pessoais.

\subsection{Recomendações para aplicação dos conceitos abordados sobre gestão de pessoas às empresas de projeto de edifícios}

O processo de gestão de pessoas numa empresa de projetos de edifícios normalmente é de responsabilidade do profissional titular, e caracteriza-se pela informalidade nos processos de recrutamento e seleção, bem como no acompanhamento do desempenho dos profissionais e critérios para o seu desenvolvimento.

As contratações e critérios relacionados ao desenvolvimento profissional, tais como treinamentos e cursos de educação continuada, não ocorrem em função de um planejamento prévio coerente com a estratégia da empresa, e sim em função de necessidades imediatas. 
Usualmente, essas empresas são caracterizadas pela curta permanência de profissionais, tanto técnicos quanto administrativos, em função da falta de planejamento, de procedimentos e de critérios que levam a contratações equivocadas, tanto do ponto de vista da empresa quanto do ponto de vista do colaborador contratado.

Do ponto de vista da empresa, porque não consegue diagnosticar adequadamente as habilidades, competências e perfis dos candidatos; para o colaborador contratado, porque não consegue entender com clareza os requisitos para o cargo, o trabalho a ser desenvolvido e as perspectivas profissionais que a empresa the oferece.

São raras as empresas de projeto de edifícios que possuem definição de cargos, e competências e habilidades necessárias para o seu exercício. Também não existe critério interno estabelecido com relação à remuneração, que acontece, inicialmente, com base no piso salarial vigente no mercado, e não existe definição prévia de faixas salariais para os cargos em função do tempo de atuação na empresa ou aperfeiçoamento profissional. Portanto, os possíveis aumentos e bonificações não são previamente estabelecidos e ficam a critério do profissional titular.

A adoção de procedimentos simples para a contratação, tais como: apresentação da empresa, roteiros de entrevistas, testes padrão para cada função, descentralização do processo de contração com o envolvimento de, pelo menos, mais um profissional - de preferência e chefe imediato do colaborador a ser contratado, viabilizaria e facilitaria os processos de recrutamento e seleção, diminuindo, dessa forma, a probabilidade de frustração em função de admissões equivocadas tanto para o colaborador, quanto para a empresa.

A elaboração de uma planilha descritiva de cargos, salários e critérios de avaliação, além de promover maior segurança para os colaboradores da empresa, poderia ser utilizada como subsídio para o recrutamento e seleção.

Além da organização formal dos aspectos relacionados à gestão de pessoas, existem outros aspectos que influenciam negativamente a rotatividade de profissionais na empresa de projeto e produtividade. Trata-se da a falta de visão e de entendimento por parte das empresas sobre os fatores que realmente motivam $o$ 
profissional atuante no segmento de projeto e, consequentemente, alimentam a criatividade e constante atualização fundamentais para o exercício profissional nesse segmento.

Verifica-se, através de revisão bibliográfica sobre o assunto, que a rotatividade de profissionais pode estar relacionada à fatores internos (clima organizacional e a oportunidades de crescimento e desenvolvimento) e externos (conjuntura, melhores oportunidades salariais e de desenvolvimento). O que se nota no segmento de projeto é que o fator relacionado à melhor remuneração é pouco impactante no nível de rotatividade das empresas, pois as ofertas salariais variam pouco de uma empresa para outra.

Os profissionais titulares das empresas de projeto normalmente preocupam-se pouquíssimo em delinear o perfil do profissional que atuará na sua empresa, no que diz respeito às questões técnicas e pessoais.

Consequentemente, não existe preocupação em estabelecer estratégias relacionadas à manutenção dos profissionais (nem financeira, nem pessoal/técnica), tais como: reconhecimento na participação de decisões ou soluções relacionadas aos projetos, atuação técnica efetiva junto ao cliente e equipe de projeto, participação em prêmios, ações que contribuam para o desenvolvimento técnico do profissional e, principalmente, retorno quanto ao desempenho do profissional, de forma a sinalizar aspectos que a empresa considera relevantes para sua estratégia de atuação.

A manutenção dos profissionais nas empresas passa pela motivação e, conforme revisão bibliográfica, esse é um aspecto preocupante para as empresas nos setores em geral. Sendo assim, o autoconhecimento por parte da empresa e, consequentemente, a reflexão sobre aspectos relacionados à gestão de pessoas desde a contratação - passando pela manutenção, desenvolvimento e motivação, até o desligamento do profissional, é o caminho mais razoável para a minimização do impacto desse aspecto para a rotina da empresa. 


\subsection{Recomendações para aplicação dos conceitos abordados sobre gestão por desempenho às empresas de projeto de edifícios}

A adequada gestão da empresas de projeto de edifícios é um desafio para os empresários desse segmento, pois, entre outros fatores, são empresas imersas num ambiente altamente competitivo e, consequentemente, hostil. Um dos fatores que levam à essa conclusão é a postura dos contratantes que, em sua maior parte, adotam um comportamento predatório do ponto de vista comercial, e com alto nível de exigência do ponto de vista técnico.

Outro aspecto que confirma a hostilidade do ambiente é o fato de as empresas estarem sujeitas a contratos sob a pressão de períodos cada vez mais curtos e complexidade técnica elevada. Entretanto, verifica-se, na maior parte das empresas de projeto, a inexistência de práticas de gestão como caminho para a eficácia dos seus processos internos e, consequentemente, para o necessário preparo, de forma a situarem-se no seu ambiente com postura proativa e competitiva.

Nesse sentido, Oliveira (2005) propõe um modelo de gestão com objetivo de organizar os processos administrativos básicos da empresa de projeto.

Posterior à organização da empresa através do método proposto por Oliveira, a administração por desempenho como método de gestão, pode levar à integração do universo corporativo, ou seja, interligar os seus diversos processos e indivíduos que atuam na empresa à sua estratégia e visão.

Por serem de pequeno porte a maior parte das empresas de projeto de edifícios, o seu natural dinamismo e flexibilidade são fatores que podem facilitar a aplicação dos conceitos da gestão por desempenho. Por se tratar de um método dinâmico, se sistematizado adequadamente, leva a empresa a constante reflexão e discussão sobre suas limitações, vantagens, desafios e possibilidades de atuação, trazendo, como conseqüência, o amadurecimento e aprendizado contínuo.

Contudo, o método exige por parte da empresa conhecimento e organização prévia de seus processos de gestão essenciais, ou seja, para que seja realmente eficaz, é necessário que a empresa se submeta à um processo de reestruturação gerencial anterior, pois a sua aplicação exige maturidade gerencial. 
Sugere-se para a implementação do método de gestão por desempenho às pequenas empresas de projeto, as etapas contempladas na Tabela 4.2. 
Tabela 4.2: Recomendações para aplicação da gestão por desempenho em empresas de projeto

\begin{tabular}{|c|c|}
\hline ETAPA & DETALHAMENTO \\
\hline 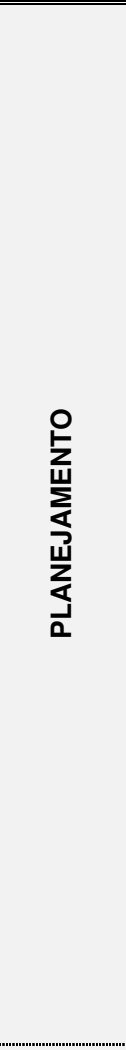 & $\begin{array}{l}\text { Identificação dos processos críticos da empresa quanto a competitividade. } \\
\text { Estabelecimento de indicadores simples, precisos e eficazes voltados para tais } \\
\text { processos, possibilitando o seu acompanhamento de desempenho, de preferência } \\
\text { para um período aproximado de dois meses. } \\
\text { Análise crítica quanto aos resultados obtidos através dos indicadores. } \\
\text { am função do diagnóstico obtido através dos indicadores e reflexões coletivas, } \\
\text { estabelecimento de objetivos estratégicos a serem desdobrados para os diversos } \\
\text { processos da empresa e, se possível, até o nível do profissional técnico. } \\
\text { Estabelecimento de metas a serem atingidas. } \\
\text { Estabelecimento do horizonte estratégico para acompanhamento dos objetivos e } \\
\text { metas fixadas. } \\
\text { Definição de um plano de ação para acompanhamento dos objetivos e metas } \\
\text { estabelecidas, contemplando os responsáveis pelo acompanhamento de cada um dos } \\
\text { objetivos e metas, ações necessárias, previsão de recursos e indicadores para } \\
\text { acompanhamento } \\
\text { **** Cuidados: A empresa deve ter em mente que trata-se de um processo de } \\
\text { aprendizado organizacional, cujo objetivo é levar a empresa à uma posição } \\
\text { competitiva. } \\
\text { A etapa de diagnóstico é fundamental para a eficácia do método. } \\
\text { Por serem, em sua maior parte, pequenas empresas, devem ser eleitos, no } \\
\text { máximo, três processos críticos a serem trabalhados por período; portanto, o } \\
\text { conhecimento dos processos que interferem diretamente na competitividade da } \\
\text { empresas é fundamental. } \\
\text { Estabelecimento de um horizonte estratégico de, no máximo, seis meses. } \\
\text { Os indicadores devem ser simples na sua alimentação e eficazes, de preferência } \\
\text { com alimentação automatizada. }\end{array}$ \\
\hline 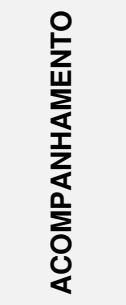 & $\begin{array}{l}\text { Devem ser realizadas reuniões sistemáticas para acompanhamento de metas. Nessas } \\
\text { reuniões, os responsáveis por cada processo devem expor suas dificuldades, os } \\
\text { benefícios ocasionados pelo acompanhamento dos processos, e as ações } \\
\text { desenvolvidas para o seu aperfeiçoamento. } \\
\text { Em função da discussão coletiva, devem ser propostas, se necessário, intervenções } \\
\text { no sentido de aperfeiçoar os processos. }\end{array}$ \\
\hline 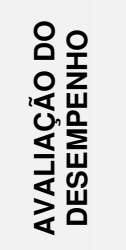 & $\begin{array}{l}\text { Ao final do período de acompanhamento, os objetivos e metas estabelecidos devem } \\
\text { ser avaliados quanto ao desempenho. } \\
\text { Na avaliação de desempenho devem ser levados em consideração os resultados de } \\
\text { atingimento de metas, dos indicadores e impressão dos profissionais que conduziram } \\
\text { o processo de gestão por desempenho. } \\
\text { Ao final desse processo, novos objetivos e metas devem ser estabelecidos. }\end{array}$ \\
\hline
\end{tabular}

\subsection{Recomendações para aplicação da gestão por desempenho ao processo de projeto}

De acordo com Melhado et al. (2005), a partir de meados da década de 90, o processo de projeto tornou-se fortemente multidisciplinar, em decorrência tanto da 
introdução de inovações tecnológicas em produtos, componentes, métodos e sistemas construtivos, quanto da necessidade de coerência entre o projeto e os requisitos técnicos e econômicos envolvidos na produção de um edifício. Nesse sentido, verifica-se um aumento da complexidade na gestão do processo de projeto, pois algumas interfaces entre as diversas disciplinas envolvidas são sutis e difíceis de serem antecipadas, mesmo por coordenadores de projeto experientes. Somamse ainda as novas exigências por parte dos construtores em relação aos projetistas em fornecer projetos cada vez mais especializados, adequados às novas demandas dos edifícios, e desenvolver projetos em prazos menores.

Alinhado à sistemática de avaliação de desempenho do processo de projeto (Tabela 4.3), Melhado et al. (2005) sugerem que, em cada uma das etapas do projeto, sejam realizadas as verificações inerentes a cada uma das disciplinas e, posteriormente, a análise crítica contratada ou desenvolvida pelo contratante. Tanto a verificação quanto a análise crítica são atividades que podem demandar modificações no projeto e, após essas duas etapas, as soluções desenvolvidas devem ser submetidas à validação pelo cliente contratante.

Além das recomendações sugeridas por Melhado et al. (2005) para análise de desempenho do processo de projeto, sugere-se ainda que a empresa estabeleça sistemáticas de controle para cada uma das etapas do processo de projeto através de listas de verificação e acompanhamento dos planos sugeridos no item 4.2 recomendações para aplicação dos conceitos de gestão de projetos à gestão do processo de projeto. 
Tabela 4.3: Recomendações para análises de desempenho durante o Processo de Projeto segundo Melhado et al (2005) na empresa de projeto

\begin{tabular}{|c|c|c|c|}
\hline Controle & Enfoque & Objetivo & Responsável \\
\hline 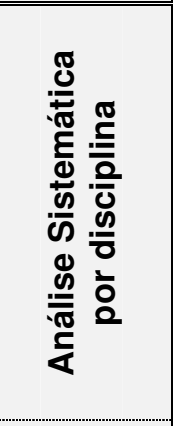 & $\begin{array}{c}\text { Por } \\
\text { disciplina, } \\
\text { durante a } \\
\text { realização } \\
\text { de cada } \\
\text { uma das } \\
\text { etapas de } \\
\text { projeto }\end{array}$ & \begin{tabular}{|l} 
- \\
- Avaliação dos aspectos legais. \\
cliente. \\
- Atendimento do atendimento às restrições colocadas pelo \\
combate à incêndio, saúde pública, etc. \\
- Nível de compatibilização das interfaces entre as \\
disciplinas de projeto. \\
- Detecção de pontos considerados mal resolvidos. \\
- Avaliação quanto aos aspectos relacionados à \\
racionalização e construtibilidade, etc.
\end{tabular} & $\begin{array}{l}\text { Projetista } \\
\text { responsável de } \\
\text { cada uma das } \\
\text { disciplinas }\end{array}$ \\
\hline 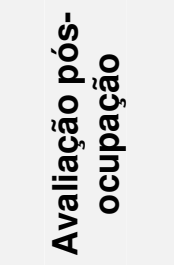 & $\begin{array}{l}\text { Individual } \\
\text { por } \\
\text { disciplina } \\
\text { (projetista) } \\
\text { / Sistêmica } \\
\text { (cliente) }\end{array}$ & $\begin{array}{l}\text { Proporcionar a retroalimentação do processo de projeto a } \\
\text { partir da ótica daqueles que executam o projeto em canteiro } \\
\text { de obras (construtor) e daqueles que utilizam e operam o } \\
\text { edifício. }\end{array}$ & $\begin{array}{l}\text { Projetista e/ou } \\
\text { Cliente }\end{array}$ \\
\hline
\end{tabular}

É importante que a empresa projetista tenha ciência de que estará sujeita à avaliação de desempenho durante todo o processo de projeto, conforme mostra a Tabela 4.4, portanto faz-se necessário preparar-se adequadamente para tais avaliações. Nesse sentido, o adequado uso do ferramental proporcionado pela gestão tornam-se fundamental. 
Tabela 4.4: Avaliação de desempenho durante o Processo de Projeto segundo Melhado et al (2005) as quais a empresas de projeto estarão sujeitas

\begin{tabular}{|c|c|c|c|}
\hline Controle & Enfoque & Objetivo & Responsável \\
\hline 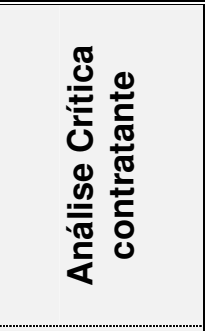 & $\begin{array}{l}\text { Por } \\
\text { disciplina, } \\
\text { durante a } \\
\text { realização } \\
\text { de cada } \\
\text { uma das } \\
\text { etapas de } \\
\text { projeto }\end{array}$ & $\begin{array}{l}\text { Avaliação do projeto ou de suas partes componentes para } \\
\text { propor alterações ou complementações, com o intuito de } \\
\text { atender a uma determinada diretriz ou objetivo: adequar } \\
\text { características do produto, aumentar sua construtibilidade, } \\
\text { reduzir custos ou prazos, otimizar métodos construtivos e } \\
\text { racionalizar a produção ou quaisquer outros que } \\
\text { contribuam para incrementar a qualidade do produto final a } \\
\text { ser entregue, a edificação. }\end{array}$ & $\begin{array}{l}\text { Desenvolvida } \\
\text { ou contratada } \\
\text { pelo cliente }\end{array}$ \\
\hline 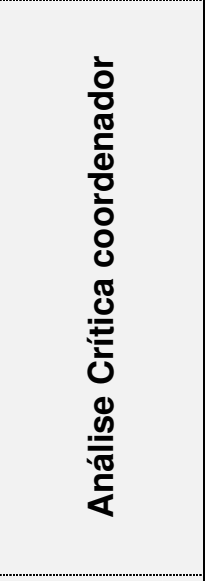 & Sistêmica & $\begin{array}{l}\text { - Identificação e análise crítica das interfaces de projeto } \\
\text { - Validação de produtos de projeto e liberação para } \\
\text { início das etapas subsequentes. } \\
\text { - Aprovação de memoriais descritivos do produto, } \\
\text { maquetes, apartamento modelo, plantas e estande de } \\
\text { vendas. } \\
\text { - Definição de subsistemas e métodos construtivos e } \\
\text { análise de alternativas tecnológicas. } \\
\text { - Análise crítica do detalhamento do projeto. } \\
\text { - Avaliação dos indicadores de projeto (compacidade de } \\
\text { fachadas, densidade de paredes, densidade de } \\
\text { pilares, taxa de armadura, espessura média de lajes, } \\
\text { etc.). }\end{array}$ & $\begin{array}{l}\text { Coordenador } \\
\text { do Projeto }\end{array}$ \\
\hline 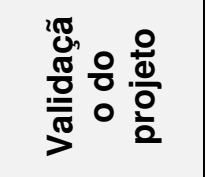 & Sistêmica & $\begin{array}{l}\text { - Aceite do projeto. Analisar se as restrições e } \\
\text { características do produto passadas previamente pelo } \\
\text { cliente-empreendedor são coerentes com as } \\
\text { informações contidas no projeto. }\end{array}$ & $\begin{array}{l}\text { Cliente- } \\
\text { Empreendedor }\end{array}$ \\
\hline 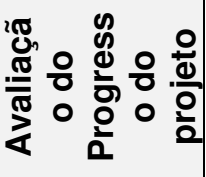 & Sistêmica & $\begin{array}{l}\text { Estabelecer referências para avaliar o progresso do } \\
\text { projeto, conhecer os recursos necessários em cada etapa, } \\
\text { monitorar o cronograma e tomar medidas corretivas em } \\
\text { caso de problemas. }\end{array}$ & $\begin{array}{l}\text { Coordenador } \\
\text { do Projeto }\end{array}$ \\
\hline 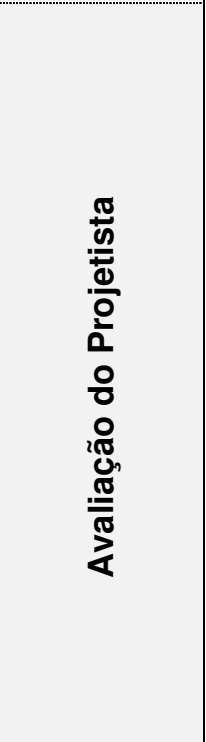 & $\begin{array}{c}\text { Por } \\
\text { disciplina }\end{array}$ & $\begin{array}{l}\text { Estimular o atendimento às necessidades dos clientes e } \\
\text { tornar o mais transparente possível tal tipo de avaliação. } \\
\text { Aspectos gerais a serem avaliados: } \\
\text { - Qualidade (atendimento do escopo, clareza na } \\
\text { apresentação, aderência às diretrizes do contratante, } \\
\text { qualidade das soluções, compatibilidade com as } \\
\text { demais disciplinas). } \\
\text { - Prazos (prazo total da entrega e prazos das entregas } \\
\text { parciais, prazo de entrega das revisões, rapidez no } \\
\text { repasses das informações). } \\
\text { Atendimento (participação em reuniões, } \\
\text { disponibilidade para esclarecimentos, integração com } \\
\text { os demais profissionais da equipe multidisciplinar, } \\
\text { proatividade no relacionamento). } \\
\text { Continua na primeira }\end{array}$ & $\begin{array}{l}\text { Cliente- } \\
\text { Empreendedor } \\
\text { e Coordenador } \\
\text { do Projeto }\end{array}$ \\
\hline
\end{tabular}




\begin{tabular}{|c||l|l|l|}
\hline \multicolumn{2}{|c|}{ Tabela 4.4: Avaliação de desempenho durante o Processo de Projeto segundo Melhado et al } \\
(2005) as quais a empresas de projeto estarão sujeitas
\end{tabular}

De acordo com as Tabelas 4.3 e 4.4, além da análise sistemática de cada uma das disciplinas, análises críticas e validação do projeto, as avaliações referentes ao desempenho devem se estender à gestão dos recursos utilizados no projeto (tempo e pessoas) e à retroalimentação e aperfeiçoamento do processo, através dos retornos dos usuários do projeto (equipe da obra ) e da avaliação pós-ocupação.

\subsection{Recomendações para implementação de Sistema e Gestão da Qualidade na empresa de projeto}

Segundo Maeda (2006), embora o Sistema de Gestão da Qualidade seja o instrumento mais abrangente para operacionalizar o planejamento estratégico (formalizado ou não) e padronizar processos e procedimentos, a certificação por si só não representa eficácia na busca da qualidade dos serviços e projetos desenvolvidos, nem agrega eficiência na gestão da empresa, sendo que é necessário empreender um esforço de engajamento, comprometimento e visão sistêmica muito grande para a obtenção de resultados favoráveis e duradouros.

O movimento pela qualidade no setor da construção civil envolvendo as empresas de projeto pode ser subdivido, basicamente, em três etapas. A primeira aconteceu no final da década de 90 e deu-se principalmente em decorrência do movimento ocorrido junto às empresas construtoras e incorporadoras do setor. Destacam-se como iniciativas desse movimento a formação do grupo piloto integrado por empresas do setor, proposto pelo SindusconSP em parceria com o CTE, cujo 
objetivo era desenvolver processos necessários à implementação de um sistema de gestão da qualidade, à criação dos programas QUALIHAB e à instituição do Programa Brasileiro da Qualidade e Produtividade do Habitat, PBQP-H.

Todo esse movimento influenciou as empresas de projeto, que procuraram, num primeiro momento, assim como seus contratantes, a implementação de sistemas de gestão da qualidade segundo a série de normas NBR ISO 9000.

A segunda etapa ocorreu no início da década atual, quando as empresas de projeto passaram a abandonar a certificação da qualidade sob o argumento de que a operação do sistema de gestão da qualidade não necessariamente justifica-se pela sua certificação. Tal iniciativa pode ser denominada como um movimento, já que diversas empresas do segmento de projetos de todas as especialidades foram influenciadas e aderiram a tal prática, conforme relatado nos trabalhos de Maeda (2006); Baía; Melhado (1999); Grilo et al (2001); Rabelo (2002).

Segundo os autores, as empresas foram motivadas a participar de tal movimento em função de dificuldades ligadas principalmente à operação do sistema, destacando-se entre elas as dificuldades financeiras, já que os custos para implementação, certificação e posterior manutenção é relativamente elevado se comparados ao faturamento mensal das empresas de projeto. Outro aspecto levantado pelos autores relaciona-se à cultura das empresas, pois os projetistas, de forma geral, encaram os sistemas de gestão da qualidade como elemento que burocratiza e influencia negativamente a atividade projetual.

Atualmente vivemos a terceira etapa, que iniciou-se com a proposição, por parte de Melhado e Cambiaghi (2006), do Referencial Normativo para Qualificação de Empresas de Projeto ao PBQP-H, posteriormente adaptado e aprovado em 2008. Espera-se que, com a adoção do modelo de gestão da qualidade para empresas de projeto proposto no referencial normativo, as empresas possam ser atendidas em suas expectativas quanto aos benefícios trazidos pelas sistemáticas da qualidade. De acordo com Maeda (2006); Baía; Melhado (1999); Grilo et al. (2001); Rabelo (2002), tais expectativas referem-se principalmente às relações com os clientes, colaboradores e fornecedores, e a um maior controle sobre retrabalhos, gerando maior facilidade na identificação das suas causas. 
O modelo proposto por Melhado e Cambiaghi (2006) parte do princípio de que as deficiências de gestão da qualidade nas empresas de projeto concentram-se principalmente na gestão dos recursos humanos, no tratamento das relações com o contratante, na documentação em geral e na comunicação interna e externa, dada a informalidade pela qual se processam.

Nesse sentido, o modelo é estruturado a partir dos requisitos do contratante e confiabilidade na prestação do serviço projetual. Tais requisitos passam pela captação e processamento de informações; definição do programa de necessidades; fidelidade às necessidades de execução e construtibilidade; cumprimento dos prazos; qualidade das informações; disponibilidade e capacidade de resposta do projetista quando solicitado. A comunicação, organização da documentação e tratamento dispensado aos clientes devem ser a base para formulação de indicadores eficazes ao sistema de gestão da qualidade proposto.

A proposição de Melhado e Cambiaghi prevê a implementação de oito processos documentados organizados três estágios: processos para preparação; processos essenciais e processos voltados para o aperfeiçoamento. Os objetivos do estágio de preparação são a caracterização da empresa, definição de metas e descrição dos processos.

O estágio essencial é voltado ao processo de projeto e fundamentado nas relações com o contratante, na organização da documentação e comunicação. No estágio de aperfeiçoamento, os processos relacionam-se às competências, ao processo de projeto, à satisfação dos clientes e à avaliação e melhoria.

O modelo prevê ainda um terceiro estágio, cujo objetivo é atender demandas de clientes em particular ou exigências específicas de projetos de grande porte ou empreendimentos com características específicas.

No próximo capítulo são colocadas as considerações finais do trabalho referentes aos seus objetivos e limitações, a pesquisa-ação junto às empresas de projeto, programa de desenvolvimento gerencial, análises da aplicação do modelo e trabalhos futuros. 


\section{CONSIDERAÇÕES FINAIS}

\section{1}

\section{Quanto aos objetivos e limitações do trabalho}

O primeiro objetivo deste trabalho consiste na análise da aplicação do Modelo de Gestão para Pequenas Empresas de Projeto sob os enfoques das reações das empresas na aplicação do modelo e resultados alcançados em função da sua implementação. O segundo objetivo diz respeito à proposição de recomendações para facilitar a aplicação dos conceitos de gestão contidos em cada um dos elementos contemplados no Modelo de Gestão proposto por Oliveira (2005).

A análise quanto às reações das empresas na aplicação do modelo foi desenvolvida no item 3.4, com base nos dados e informações coletados durante a pesquisa-ação, e referem-se ao comportamento das empresas em grupo, estratégias e sistematizações adotadas pelas empresas para a implementação do modelo e dificuldades no desenvolvimento das tarefas.

Quanto ao comportamento das empresas, a análise visou a conduta em grupo (resistências e aproveitamento das oportunidades) e quais os recursos utilizados pelos pesquisadores para gerenciar as situações ocorridas.

Foram analisados os desenvolvimentos das tarefas propostas em ambos os grupos, e como as empresas as conduziram em função de seus anseios e limitações. Também analisou-se como as empresas conduziram o trabalho individualmente, como atribuíram responsabilidades na implementação do modelo, envolvimento dos colaboradores e estratégia de trabalho adotada.

Como fechamento do item, foram analisadas as dificuldades específicas ao desenvolvimento de cada um dos elementos de gestão propostos no modelo, e as dificuldades gerais das empresas apresentadas ao longo dos programas.

A análise relativa aos resultados alcançados pelas empresas em função da implementação do modelo foi apresentada no Item 3.5 , e refere-se ao 
aproveitamento dos conceitos de gestão transmitidos às empresas durante os programas e no desenvolvimento de ferramentas e procedimentos, à mudança de postura e à continuidade do desenvolvimento gerencial nas empresas. Tal análise foi conduzida a partir dos dados e informações coletados durante a pesquisa-ação e do questionário final, aplicado um ano após a finalização do PDGEP 1, e sete meses após a finalização do PDGEP 2.

A proposição de recomendações foi apresentada no Item 4. Essas recomendações foram elaboradas a partir da revisão bibliográfica e experiências durante a pesquisaação, e objetivam facilitar a implementação do referido modelo, alinhadas às diretrizes gerais e específicas propostas por Oliveira (2005) no seu trabalho de Doutoramento.

Com base no exposto, pode-se considerar o objetivo geral desse trabalho atendido, pois foram apresentadas diversas informações teóricas e práticas provenientes da experiência prática durante a pesquisa-ação e da revisão bibliográfica, proporcionando, dessa forma, conhecimentos essenciais às empresas de projeto com foco à implementação do modelo de gestão proposto por Oliveira (2005).

As limitações do trabalho referem-se à revisão bibliográfica, aos resultados alcançados pelas empresas e ao seu contexto setorial.

A principal dificuldade na condução da revisão bibliográfica referiu-se à escassez de publicações voltadas às pequenas empresas da construção civil no Brasil e em outros países. As referências da área de conhecimento de Administração de Empresas, em sua grande maioria, referenciam casos voltados à realidade de grandes empresas cujas atuações não se dão no setor da construção civil.

Outra dificuldade encontrada relaciona-se à abrangência de cada um dos temas pesquisados pois, apesar de serem assuntos inter-relacionados, tratam-se de temas complexos e, portanto, estudados e explorados individualmente em profundidade. Nesse sentido, e estruturação e delimitação da revisão foi um ponto crítico do trabalho, uma vez que existiu o risco de, além de transformá-las na repetição de outras publicações, torná-las demasiadamente extensas, pois todos os temas abordados já foram exaustivamente discutidos e publicados. 
Sobre as análises dos resultados alcançados pelas empresas em função da aplicação do modelo, o trabalho acabou apresentando as seguintes limitações:

- Os resultados analisados foram qualitativos, não sendo contemplados os resultados quantitativos. Uma vez que as empresas apresentaram elevada dificuldade em desenvolver indicadores para processos simples, mostrou-se inviável solicitar-lhes o desenvolvimento de indicadores para medir o seu desempenho global, inviabilizando, dessa forma, a obtenção de dados quantitativos sobre aos resultados alcançados pelas empresas.

- Não foi contemplada a análise dos resultados junto aos clientes das empresas de projeto.

Cabe comentar, ainda, o contexto setorial dos resultados, já que o desenvolvimento gerencial extrapola as fronteiras das empresas, conforme abordado no Item 1.2 Justificativas para o trabalho. Os programas aqui descritos têm a sua importância para o segmento de projetos, uma vez que as empresas que deles participaram decidiram pela adesão em função da inexistência de programas similares nas associações de classe e sindicatos.

Através de discussões realizadas durante o trabalho do PDGEP, conclui-se que a gestão das empresas de projeto é um problema endêmico nesse segmento, ainda não encarado adequadamente pelas associações e sindicatos representantes dos profissionais que nele atuam.

De forma geral, através da pesquisa verificou-se que as empresas, ao associaremse a uma entidade de classe, o fazem na expectativa de que os problemas setoriais que as atingem diretamente sejam seriamente discutidos e tratados. Também constatou-se, através de pesquisa nos diversos websites das associações e sindicatos, que tal expectativa coincide com os objetivos contidos nos seus estatutos, uma vez que, genericamente, visam defender os interesses de seus associados através de iniciativas, pesquisas e ações.

Visando cumprir os objetivos estatutários das associações e contribuir para a solução de problema setorial aqui discutido, qual seja, a gestão das empresas de projeto, recomendam-se às associações e sindicatos ações institucionais no sentido 
de criar oportunidades para o desenvolvimento gerencial dos seus associados, uma vez que ações isoladas, a exemplo do PDGEP 1 e 2, embora sejam de extrema importância, são pouco eficazes para a solução de problemas setoriais.

\subsection{Quanto à pesquisa-ação junto às empresas de projeto}

Durante a pesquisa-ação, o papel da metodologia foi fundamental para o controle das técnicas utilizadas na coleta de dados, resolução de problemas, organização das ações, elaboração de diagnósticos, técnicas na realização de entrevistas e condução de reuniões coletivas.

Através de revisão bibliográfica sobre o método pesquisa-ação, verificou-se que o mesmo deve ocorrer dentro de um processo denominado "Espiral Cíclica", que consiste na integração entre pesquisa, reflexão e ação retomada continuamente dentro do trabalho de pesquisa.

A atuação dos pesquisadores no contexto dos grupos objetivou facilitar o processo de implementação do modelo e levar o grupo à reflexão crítica constante. De acordo com Thiollent (2004), esta estratégia denomina-se pesquisa-ação crítica, cujo objetivo é compreender o contexto da pesquisa e levá-lo a transformação através de negociações coletivas.

Este processo deve levar a um processo de reflexão-ação coletivo, no qual o sujeito (empresas) deve tomar consciência das transformações que ocorrerão em si próprio e no processo. Tal metodologia assume um caráter emancipatório, e a transformação almejada na pesquisa é o uso e a adequação, por parte das empresas, dos princípios propostos no modelo de gestão de Oliveira (2005) e dos métodos utilizados para a sua implementação.

Nesse sentido, durante 0 trabalho dos PDGEP 1 e PDGEP 2, houve diversos momentos de reflexão visando a reformulação das estratégias de atuação e ações dos pesquisados junto aos grupos de empresas, tais como: realização dos diagnósticos, implementação dos módulos, método de condução das reuniões 
coletivas e visitas às empresas, proposições de tarefas e dinâmicas durante as reuniões e reformulação de ferramentas para condução da pesquisa.

Em função do caráter emancipatório do método, é difícil prever a dinâmica da pesquisa nos seus mais diversos momentos. Nesse sentido, torna-se fundamental aos pesquisadores uma postura crítica e de liderança para conduzir tais transformações, com objetivo de não permitir dispersão com relação ao foco principal do trabalho.

Quanto aos recursos utilizados para a condução da pesquisa (questionários, roteiros de visitas e agendas das reuniões coletivas), é fundamental que sejam planejados e analisados periodicamente, pois a indisciplina e a desorganização podem comprometer os objetivos de todo um programa de trabalho.

A eficácia do trabalho realizado em ambos os grupos foi garantida em função das características intrínsecas do método e das suas possibilidades de negociações coletivas, uma vez que é peculiar aos profissionais do segmento de projetos, tanto titulares quanto colaboradores, a postura crítica diante dos mais diversos assuntos, principalmente aqueles que interferem diretamente nas suas empresas. Portanto, a imposição de um método sem a possibilidade de interferência e interação dos participantes seria inviável num trabalho cujo objetivo principal era 0 desenvolvimento gerencial das empresas de projeto.

Quanto às características gerais dos grupos PDGEP 1 e PDGEP 2, optou-se pela formação de grupos heterogêneos, pois, apesar das diferenças entre as empresas em diversos aspectos, seus anseios, suas deficiências e suas dificuldades são semelhantes.

Outro aspecto interessante relacionado à diversidade de ambos os grupos refere-se à postura particular dos profissionais das diferentes especialidades de projeto. A interação proporcionada pelos PDGEP 1 e 2 entre os diferentes perfis de projetistas naturalmente acabou contribuindo para o amadurecimento individual, uma vez que a constante possibilidade de troca de idéias e experiências a partir de diversos pontos de vista sobre o mesmo problema ou assunto proporcionou aos participantes novas visões quanto às possibilidades de soluções gerenciais para suas empresas. 
Infelizmente a interação entre as empresas durante o PDGEP 1 e 2 deu-se apenas durante as reuniões coletivas. No entanto, o método pesquisa-ação possibilita a extrapolação das interações e, portanto, a ampliação da exploração da diversidade dos grupos.

Partindo dessa premissa, sugere-se para grupos futuros, como possibilidade de ampliar tal interação, visitas mútuas, ou seja, ao invés das visitas às empresas serem realizadas somente pelos pesquisadores, passariam a acontecer também com a presença de membros das demais empresas, acompanhados pelos pesquisadores.

Como método, as visitas seriam sistematizadas em relação à periodicidade, foco e organização. A aplicação das visitas mútuas possibilitaria maior exploração da diversidade do grupo através de troca de experiências e cooperação, de forma a potencializar a implementação do modelo, além de conduzi-las à maturidade empresarial.

\subsection{Quanto ao programa de desenvolvimento gerencial para empresas de projeto, análises sobre a aplicação do modelo de gestão e recomendações para facilitar a sua implementação}

O Item 3.3 descreveu como o trabalho de desenvolvimento gerencial foi conduzido. Basicamente, o trabalho foi estruturado em três etapas: diagnóstico, reuniões coletivas e proposições de tarefas.

Os diagnósticos tinham como objetivo entender as práticas de gestão vigentes nas empresas antes da implementação do modelo, além conduzir a estruturação das reuniões e as proposições de tarefas.

As reuniões coletivas focavam a equalização dos conceitos contidos no modelo de Oliveira (2005), além de proporcionar a interação entre as empresas, conforme já colocado.

O acompanhamento da realização das tarefas era realizado através das visitas às empresas e das exposições nas reuniões coletivas. 
A obtenção de informações quanto à continuidade do desenvolvimento gerencial das empresas após a finalização dos programas foi possível através da aplicação de um questionário final.

De forma geral, existe por parte dos gestores das empresas de projeto uma dificuldade em entender as inter-relações entre os diversos processos de suas empresas. Portanto, torna-se fundamental que o desenvolvimento gerencial de tais empresas seja estruturado a partir da visão sistêmica, uma vez que a compartimentação gerencial pode, em princípio, conduzir à eficiência pontual, mas a eficácia não é garantida.

Outro aspecto relevante relacionado ao desenvolvimento gerencial refere-se ao autoconhecimento. $\mathrm{O}$ amadurecimento empresarial deve ser pautado num processo de constante autocrítica, não limitado pela implementação de um modelo de gestão, pois é pouco provável que uma empresa seja adequadamente organizada a partir de avaliações superficiais sobre sua conduta, limitações e possibilidades.

Nesse sentido, mais relevante do que o desenvolvimento de ferramentas e procedimentos, é a transformação da postura do gestor em relação à sua empresa e ao contexto no qual ela está inserida. Tal transformação passa pela ciência da importância do autoconhecimento; logo, o estabelecimento de estratégias visando a competitividade é a conseqüência natural desse processo.

Em função das dificuldades das empresas quanto ao autoconhecimento e visão sistêmica, questiona-se se a divisão em módulos é a alternativa mais adequada para a implementação do modelo de gestão.

Em cada um dos elementos de gestão do referido modelo (planejamento estratégico, estrutura organizacional, gestão de recursos humanos, gestão financeira, gestão comercial e marketing, sistema de informação, serviços agregados e desempenho), estão contidos diversos processos de gestão. Observou-se, durante a pesquisaação, como sendo este o principal indutor à dificuldade de compreensão sistêmica dos gestores. 
Nesse sentido, como alternativa ao método de implementação por módulos, sugerese a implementação do modelo de gestão por grupo de processos a partir das seguintes etapas:

- Etapa 1 (Geral): Uniformização dos conceitos contidos no modelo de Oliveira (2005) através de reuniões coletivas, com proposições de dinâmicas cujo objetivo seria facilitar a compreensão dos conceitos e as possibilidades de aplicá-los às empresas de projeto. Durante a uniformização teórica, uma reunião deveria ser direcionada às práticas de planejamento e ferramentas, visando a preparação das empresas com relação à constante necessidade de ações planejadas para a implementação do modelo.

- Etapa 2 (Geral): Ao invés de trabalhar os módulos de gestão, trabalhar os processos neles contidos. Nessa etapa seriam identificados os diversos processos e a seqüência de trabalho. Através das experiências durante o PDGEP 1 e 2, verificou-se que, se comparados os processos das empresas de projeto, a maior parte deles são comuns (processo de projeto, processo de recrutamento, seleção e contratação de pessoal, processo de controle financeiro de projetos, processo de planejamento estratégico, processo de organização de produtos e serviços oferecidos aos clientes, processo de organização dos clientes, processo de elaboração de propostas e contratos), existindo alguns processos específicos à cada empresa. Nesse sentido, na etapa 2, serão identificados e trabalhados somente os processos comuns.

- Etapa 3 (Por grupo de processos): Planejamento das ações e de recursos para as etapas $4,5,6$ e 7 .

- Etapa 4 (Por grupo de processos): Para cada um dos processos, o primeiro estágio de trabalho compreenderia a análise crítica com relação a esse processo, através da sua descrição, ferramentas relacionadas e inter-relação com outros processos de gestão.

- Etapa 5 (Por grupo de processos): Em função da análise crítica, organização dos processos em pauta através de procedimentos e/ou ferramentas. 
- Etapa 6 (Por grupo de processos): Operacionalização dos processos através dos procedimentos e/ou ferramentas.

- Etapa 7 (Por grupo de processos): Análise crítica e reformulação, se necessário, dos processos reestruturados.

- Etapa 8 (Por grupo de processos): Nessa etapa seriam identificados os processos específicos à cada empresa. Assim como os processos comuns, as empresas individualmente deveriam planejar os recursos e ações para as etapas de análise crítica, organização e reformulação dos processos. Para que o trabalho não perca o caráter coletivo, as empresas exporiam os trabalhos referentes aos processos específicos para as demais empresas com objetivo de submeterem-se à análise do grupo quanto à pertinência e eficácia das soluções propostas.

A escolha pelo método de implementação deve ser uma decisão coletiva, pois a eficácia do método está diretamente relacionada às características das empresas que compõem o grupo e ao tempo total disponibilizado para o programa, pois para os grupos que optarem pelo método "Por Grupos de Processos", o tempo disponibilizado para as etapas 3, 4, 5, 6 e 7 deve representar pelo menos 2/3 do tempo total do programa, uma vez que o método exige, por parte das empresas, a predisposição para revisões constantes de todos os processos de gestão.

Durante o PDGEP 1 e PDGEP 2, constatou-se que os primeiros planos e ferramentas desenvolvidos pelas empresas normalmente eram incoerentes com as suas características e limitações; portanto, de difícil aplicação. Logo, nos trabalhos de desenvolvimento gerencial, as revisões são recorrentes, qualquer que seja o método de trabalho escolhido, pois os equívocos iniciais e posteriores revisões fazem parte do processo. Dessa forma, a predisposição para a constante "açãoreflexão-ação" é fundamental para o amadurecimento empresarial.

As análises sobre a aplicação do modelo estão contempladas nos itens 3.4 e 3.5, e referem-se às reações das empresas na sua aplicação e resultados alcançados.

O primeiro aspecto a ser destacado em função das análises refere-se à implementação do modelo de gestão individualizada ou em grupo. Com relação a 
esse aspecto, fica o questionamento quanto à viabilidade da implementação autônoma, já que a única experiência ocorreu em grupo.

Para as empresas que optarem pela implementação individual, sugere-se atenção especial com relação às dificuldades relacionadas, principalmente as gerais, pois uma vez não diagnosticadas e tratadas adequadamente, poderão levar a empresa a um processo de desgaste e desmotivação, comprometendo, dessa forma, a implementação do referido modelo.

Contudo, a iniciativa sobre a implementação do modelo deve ocorrer a partir da necessidade de controlar gastos, otimizar lucros e aperfeiçoar processos e, nesse contexto, as deficiências e dificuldades não devem ser tratadas como obstáculos, e sim como elementos propulsores do desenvolvimento gerencial, pois a identificação dos problemas faz parte do ciclo de gestão, uma vez que é a partir delas que devem ser planejadas, operacionalizadas e controladas as soluções gerenciais para as empresas de projeto.

Quanto à sistematização das ações, conforme já comentado, através das experiências vividas no PDGEP 1 e 2 , as empresas que envolveram os colaboradores e sistematizaram suas ações foram as que, ao final do programa, puderam visualizar resultados imediatos em função da implementação do modelo.

Uma vez que o desenvolvimento gerencial requer a ciência de que não se trata de um trabalho a ser conduzido nas horas vagas, este deve ser encarado como um projeto de reestruturação e, como tal, incorrerá no consumo de recursos. Logo, a sua eficácia está atrelada à predisposição, por parte da empresa, em planejar, controlar e retroalimentar cada etapa do programa como "sub-projetos".

Isto posto, tanto o planejamento geral do projeto quanto os planos de ação dos "subprojetos", devem ser pautados em objetivos claros a serem alcançados, em previsão das etapas de trabalho, em tempo para sua realização e atribuição de responsabilidades. Também devem ser definidos na etapa de planejamento os métodos de controle sobre a implementação.

À principio, estas parecem ser diretrizes muito rígidas para serem aplicadas às pequenas empresas de projeto. Os gestores das empresas de projeto devem estar 
atentos de que a inexistência de objetivos claros, de determinação e de disciplina nos controles durante a implementação do modelo, são os principais ingredientes da sua ineficácia.

A proposição das recomendações aqui feitas justifica-se pela dificuldade das empresas em compreender os conceitos gerais contidos em cada um dos elementos e a inter-relação que existe entre os mesmos.

O objetivo das recomendações é, a partir da revisão bibliográfica e das experiências adquiridas durante o PDGEP 1 e PDGEP 2, aplicar os conceitos de gestão à realidade e às características gerais das empresas de projeto, além de fornecer parâmetros ou ferramentas para facilitar a operacionalização de tais conceitos à realidade dessas empresas.

Quanto a estrutura organizacional, considera-se que a indicação de uma tipologia específica para as empresas de projeto de edifícios pode levar à organização equivocada ou à falsa sensação de organização, pois mesmo as empresas de projeto para edifícios de mesma especialidade possuem características individuais bastante específicas e divergentes.

Nesse sentido, a escolha da estrutura organizacional da empresa de projeto de edifícios deve ocorrer a partir da reflexão e das análises internas da sua forma de trabalho e preferências organizacionais, que normalmente são divergentes, mesmo em empresas de projeto com especialidade similar.

Como já colocado, tão relevante quanto a escolha de um determinado modelo de estrutura, é a adequada atribuição de responsabilidade e autoridade dentro da empresa de projeto. Para o caso de uma pequena empresa, pode tornar-se complexo e inviável revelar tais aspectos através de um organograma.

Para tanto, sugere-se que, antes da escolha de um modelo que retrate melhor as relações de autoridade e atribuições de responsabilidades internas, ocorra a reflexão sobre qual instrumento utilizar, levando-se em consideração que a estrutura deve ser aderente ao dinamismo que é peculiar às empresas de projeto, proporcionando-lhes, dessa forma, a flexibilidade necessária à sua rotina de trabalho. 
Quanto ao processo de projeto, embora a elaboração do plano proposto na Tabela 4.1 possa parecer complexa e inviável para as pequenas empresas atuantes no segmento de projeto do setor da construção civil, recomenda-se, pelo menos antes do início de cada um dos projetos contratados, a discussão dos tópicos propostos para o plano geral de projetos, no sentido definir diretrizes relacionadas à gestão do tempo, recursos, comunicação, tratamento da informação e desenvolvimento operacional do projeto.

No entanto, para empresas (mesmo que de pequeno porte) que venham a desenvolver projetos envolvendo mais de três colaboradores, cujo tempo de trabalho ultrapasse um mês, recomenda-se a confecção do plano geral de projetos no sentido de viabilizar a sua gestão (planejamento das atividades e de recursos, controle do processo e posterior retroalimentação).

Ante o exposto, a empresa de projeto, seja qual for seu porte, especialidade e tipologia de projeto, deve estar atenta à necessidade de gestão do processo de projeto. Para tanto, esse processo deve ser conduzido a partir da reflexão coletiva e organizada dentro da empresa, de modo a definir e desenvolver ferramentas coerentes com suas características individuais, partindo dos princípios de planejamento, controle e retroalimentação operacionáveis no contexto da empresa.

Quanto ao planejamento estratégico, o "Modelo Produtivo" proposto por Liedtka (2000), que enfatiza o pensamento estratégico coletivo subsidiado pelo diálogo e troca contínua de experiências, baseado no senso de urgência e em propostas organizacionais para toda a empresa, pode ser o mais adequado para a empresa de projeto de edifícios.

Nesse sentido, visando a eficácia do planejamento estratégico das empresas de projeto, a implantação deste modelo deve ser conduzida de forma a envolver o maior número possível de colaboradores, pois os profissionais atuantes nessas empresas são, em sua maioria, especialistas, e possuem visão bastante clara do mercado no qual atua e senso crítico aguçado em relação às posturas empresarias adotadas. Sendo as empresas de pequeno porte, a troca contínua de experiências é facilitada, viabilizando desta forma a prática do modelo. 
Quanto à gestão financeira da empresa de projeto, a falta de controle e organização da sua atividade básica impossibilita a eficácia de qualquer sistema de gestão, por mais sofisticado que o seja. Nesse sentido, não são aplicáveis as recomendações propostas no item 4.1.4 para a empresa de projeto que não possui, pelo menos, o controle da aplicação do principal recurso da sua atividade-fim, ou seja, o número de horas despendidas por cada um dos profissionais nos projetos em que atuam, e que, posteriormente, não analisa tal indicador.

Sobre a gestão da informação, as empresas de projeto, quando analisadas do ponto de vista da necessidade e fluxo de informações, caracterizam-se por sistemas de trabalho colaborativos e com necessidade de comunicação interna e externa constante, pois neste tipo de empresa realiza-se, predominantemente, o trabalho em grupo formado por indivíduos especialistas em diversas áreas e atuantes em diferentes localidades geográficas, mas com um objetivo comum.

Diante de tais características, o sistema de informações, além de fornecer acesso e confiabilidade para a informação, deve dispor de um sistema de comunicação que leve em consideração os seguintes aspectos: os participantes do processo, as fontes e destinos da comunicação e informação, a localização dos remetentes e destinatários, tempo entre o envio e recebimento da informação, acesso e o meio que viabilizará a comunicação e troca de informações.

Quanto à gestão comercial e aplicação das recomendações propostas no item 4.1.6, tão importante quanto o conhecimento das características do mercado consumidor e o adequado delineamento dos serviços de projeto, é estabelecer a estratégia de comunicação e de venda junto ao seu mercado.

Sobre gestão de recursos humanos, considera-se que, por serem em maior parte de pequeno porte, as empresas de projeto possuem uma série de limitações relacionadas a recursos financeiros, portanto, no oferecimento de planos de carreira para os seus colaboradores a longo prazo. No entanto, a definição de procedimentos simples e eficazes demonstraria, por parte da empresa, seriedade na relação para com seus colaboradores, além de proporcionar maior organização e facilitar a sua gestão. 
A aplicação da gestão por desempenho nas empresas de projeto pode se revelar um método eficaz, para o caso da empresa já ter atingido um certo grau de maturidade gerencial através do conhecimento e organização dos seus processos essenciais. $O$ método permite a expressão do planejamento empresarial ao nível de competência de cada indivíduo, como já colocado por Stoffel (1997). Nesse sentido, o método coincide com o fato da eficácia dos processos das empresas de projeto ser altamente influenciado pelos profissionais técnicos que nelas atuam, profissionais esses com senso crítico bastante elevado. Além disso, a sua aplicação possibilita o envolvimento de todos os indivíduos da empresa no processo de gestão.

Sobre a avaliação de desempenho voltado a cada um dos projetos desenvolvidos pelas empresas, sugere-se, através de indicadores de desempenho, especial cuidado na sua elaboração, pois entre os diferentes projetos desenvolvidos pela empresa e até mesmo entre as etapas de trabalho, os critérios de avaliação podem mudar significativamente. Ressalva-se ainda que, em função do seu caráter inconstante, tais controles não podem ser generalizados e devem ser analisados com critério, pois cada um dos projetos ocupam a sua importância no contexto da empresa e, portanto, devem ser analisados quanto ao seu desempenho, mesmo que pontual, quanto aos mais diversos aspectos (tempo, soluções tecnológicas, atendimento dos requisitos do cliente, retrabalhos, etc) 
Como proposta para trabalhos futuros sugere-se:

- Trabalho voltado à organização e acompanhamento do segmento de projetos pois, através de pesquisa, verificou-se a escassez de dados e informações relevantes nesse segmento. $O$ trabalho partiria da organização da empresa de projeto através da implementação do método de gestão por desempenho, de forma a gerar, em função dos indicadores definidos, dados para alimentar indicadores setoriais estabelecidos através de consenso entre as diversas associações representantes dos profissionais de projeto. $O$ objetivos dos indicadores seria, em principio, expressar as características gerais e a evolução do segmento de projetos, de forma a viabilizar o diagnóstico de possíveis problemas e gargalos, passíveis de ações institucionais visando o desenvolvimento setorial.

- Quanto à gestão da empresa, mais especificamente aquela voltada à gestão dos seus processos internos, sugere-se o desenvolvimento de um trabalho direcionado à gestão do processo de projeto a partir dos princípios de "administração de projetos"3. Observou-se durante a pesquisa como sendo esse um dos principiais anseios das empresas de projeto, justificado por ser 0 processo de projeto o principal processo da empresa de projeto, com influência direta sobre os demais processos de gestão da empresa. Por se tratarem de trabalhos com início e término pré-estabelecido, com consumo de recursos e elevado nível de interação com agentes externos, a aplicação dos conceitos de "gestão de projetos" é possível; no entanto, considerações sobre as características particulares do processo de projeto devem ser levadas em consideração. Sendo assim, o objetivo do trabalho seria o de propor diretrizes para a gestão do processo de projeto a partir dos princípios de "gestão de projetos".

\footnotetext{
${ }^{3}$ Os princípios de "admnistração de projetos" citados referem-se à metodologia voltada para o Project Management
} 
- Ainda alinhado à gestão da empresa, sugere-se a elaboração de um trabalho voltado à gestão da informação nas empresas de projeto. Verificou-se durante pesquisa a escassez de ferramentas de tecnologia da informação voltadas à gestão da empresa de projeto. Alinhado a esse fato, as empresas de projeto, de forma geral, desconhecem o fluxo de informações inerente a cada um dos seus processos e, consequentemente, ignoram a arquitetura geral mais adequada ao seu sistema de informação. Através de pesquisa-ação, o objetivo do trabalho seria através da aplicação de um método para mapeamento do fluxo de informações gerenciais da empresa de projeto, identificar os gargalos, a inexistência ou ineficácia de ferramentas para adequada coleta, organização e disponibilização das informações gerenciais, a partir dessa análise, estruturar o sistema de informações da empresa de projeto individualmente. 


\section{REFERÊNCIAS}

ABIKO, A. K. et al.. Setor de Construção Civil: Segmento de Edificações.

Brasília: Senai, (Série Estudos Setoriais do SENAI),2005. 154p.

$A D E Y E Y E, K$ et al.. Using digital information for hybrid project design -CIB WORLD BUILDING CONGRESS PROCEEDINGS, Cape Town, South Africa,2007. pp 1024-1036.

ANDERY,P.R.P. et al.. Certificação de Empresas de Projetos. Um estudo de caso. ANAIS DO II WORKSHOP BRASILEIRO DE GESTÃO DO PROCESSO DE PROJETO NA CONSTRUÇÃO DE EDIFÍCIOS,2002. 6p.

ARANTES, E.M., VIEIRA, M.P., ANDERY,P.R.P.. Impacto do Sistema de garantia da qualidade em empresas de projeto sobre as suas tecnologias da informação ANAIS DO V WORKSHOP BRASILEIRO DE GESTÃO DO PROCESSO DE PROJETO NA CONSTRUÇÃO DE EDIFÍCIOS, 2005. 6p.

ASSOCIAÇÃO BRASILEIRA DE NORMAS TÉCNICAS. Sistemas de Gestão da Qualidade - Requisitos. NBR ISO 9001:2000, Rio de Janeiro,2000.

ATKINSON, A.A.et al.. Advanced management accounting. $2^{\circ}$ Edição. Englewood Cliffs, N.J. : Prentice Hall,1989.817p.

BAÍA, J.L; MELHADO, S.B.. Implantação de um sistema de gestão da qualidade em empresas de arquitetura. Boletim Técnico BT/PCC/221 - Escola Politécnica, Universidade de São Paulo. São Paulo, 1998.25p.

BANAITINE,N., et al... Evaluation the life cycle of a building : A multivariate and multiple criteria approach. Omega. the International Journal of Management Science. Volume 36, pp 429-441.

BATEMAN,T.S.,SNELL,S. A.A .. Administração. Construindo Vantagem Competitiva. $8^{\circ}$ Edição. São Paulo. Editora Atlas, 1998. 539p.

BERNROIDER,E.. Factors in SWOT Analysis Applied to Micro, Small-toMedium, and Large Software Enterprises: An Austrian Study. European Management Journal, Volume 20, N5, pp 562-573,2002.

BODIE,Z.,MERTON,R.C.. Finanças. 1Edição. Porto Alegre Editora Bookman, 2002. 436p.

BRICKLEY,J.A.,SMITH JR.,C.W., ZIMMERMAN,J.L.. Designing Organizations to Create Value. $1^{\circ}$ Edição. New York . Editora McGraw - Hill, 2003.308p.

BURTON, R. M.. Strategic Organizational Diagnosis and Design. Boston. Kluwer Academic Publishers, 1998.512p

CARARO, F.J., WILLE, S.A.C.. Fluxograma de atividades para a formação de preço de venda de projetos e serviços técnicos para escritórios de arquitetura. ANAIS DO VI WORKSHOP BRASILEIRO DE GESTÃO DO PROCESSO DE PROJETO NA CONSTRUÇÃO DE EDIFÍCIOS, 2006. 10p. 
CARARO, F.J., WILLE, S.A.C.. O planejamento e custeio de projetos das edificações e serviços técnicos para formação de preço em escritório de projetos. ANAIS DO VI WORKSHOP BRASILEIRO DE GESTÃO DO PROCESSO DE PROJETO NA CONSTRUÇÃO DE EDIFÍCIOS, 2006. 10p.

CARDON, M. S., STEVENS C.E.. Managing human resources in small organizations: what do we know? Human Resource Management Review, $N^{\circ} 14$, 2004. pp 294-323.

CARVALHO,M.M.,PALADINI,E.P.. Gestão da Qualidade . Teoria e Casos . $1^{\circ}$ Edição São Paulo. Editora Campus, 2006.339p.

CASTELO,A.M., GARCIA,F.. Crescimento movido a crédito Conjuntura da Construção, AnoV, N², 2007. pp 17-19.

CHAPMAN,R.J.. The role of system dynamics in understanding the impact of changes to key project personnel on design production within construction projects. International Journal of Project Management v.16,n.4, p. 235-247 .1998.

CHEN,P, PARTINGTON,D. Three conceptual levels of construction project management work. International Journal of Project Management, Volume 24,2006. pp 412-421.

CHIAVENATO, I.. Administração de Recursos Humanos. $1^{\circ}$ Edição. São Paulo . Editora Atlas,1989. 385p.

CHOMA, A.A.. Terceirização do escritório de projeto e da gestão das aquisições na construção civil. ANAIS DO V WORKSHOP BRASILEIRO DE GESTÃO DO PROCESSO DE PROJETO NA CONSTRUÇÃO DE EDIFÍCIOS, 2005. 7p.

CIB WORLD BUILDING CONGRESS,2007, South Africa,2007. Proceedings..., Cape Town:2007. CD-ROM.

COELHO,S.B.S.,NOVAES,C.C, MATTAR,D.G.. Estudo comparativo dos recursos disponíveis em extranet colaborativa de gestão de projetos, com base em sistemas proprietários ou em software livres. ANAIS DO XI ENCONTRO NACIONAL DE TECNOLOGIAS DO AMBIENTE CONSTRUÍDO. A CONSTRUÇÃO DO FUTURO,2006, Florianópolis, SC.13 p.

COLIN,G., AL BIZRIAI,S., ATIKIN,B.. Web supported process management to achieve consistent international project team integration and performance. CIB WORLD BUILDING CONGRESS PROCEEDINGS ,2007, Cape Town, South Africa,2007.pp 1062-1071.

COMCIC- Comitê da Cadeia Produtiva da Industria da Construção Civil/ FIESP. A construção do desenvolvimento sustentado. A importância da construção na vida econômica e social do país. São Paulo, 2006.44p.

CRAGG,P., ZINATELLY,N.. The evolution of information system in small firms. Information \& Management $\mathrm{N}^{\circ} 29$, 1995. pp 1-8. 
CTE- Centro de Tecnologia de Edificações. Informativo Dezembro/2008. Um momento de oportunidades: as conclusões do II encontro de diretores técnicos e gestores da construção. Disponível em http://www.cte.com.br Acesso em 23, Dez. 2008.

DECONCIC- Departamento da Indústria da Construção/ FIESP. Proposta de política industrial para a construção civil- Edificações. São Paulo, 2008. 170p.

DEMING, W.E.. TURBAN,E.,MCLEAN,E.,WETHERBE,J.. Qualidade: A Revolução da Admnistração. $2^{\circ}$ Edição. Rio de Janeiro. Editora Marques Saraiva,1990.357p.

DENZIN,NORMAN K. \& LINCOLN, YVONA S.. Handbook of Qualitative Research - Printed in United States of America. 2ํㅡㄹ Ediçâ, 2000. Sage Publicatios, Inc.1065p.

DICKSON, P. et al.. Managing Design in smallhigh- growth companies. Journal of product Innovation Mangement. Volume 12. Issue 5. November 1995. pp 406414

DRUCKER, P.. Administrando em tempos de grandes mudanças. São Paulo. Editora Pioneira, 5o edição, 1999. 286p.

DUARTE,T.M.P., SALGADO,M.. Certificação de Empresas de Projeto no Rio de Janeiro : indicativo da situação. ANAIS DO I WORKSHOP NACIONAL DE GESTÃO DO PROCESSO DE PROJETO, 1999. 4p.

E. BROOKFIELD et al.. The Architectural technologist role in linking lean design with lean construction. Proceedings of 12 th Annual Conference on Lean Construction, 2004 - iglc2004.dk. 13p.

EIKELAND, O. Condescending ethic and action research . Action Research, Sage Publicatiosn, London, v.4 (1), pp. 37 - 47 / 2006.

EMMITT, S., SABDER, D. , CHISTOFFERSON, A.K.. The value universe: defining a value based approach to lean construction. Conference of the International Group for Lean Construction Proceedings, 2005 - iglc.net

EMMITT, S., SABDER, D. , CHISTOFFERSON, A.K.. Implementing value through lean design management. ... International Group for Lean Construction (IGLC) Conference-iglc2004.dk

EMMITT, S.. Architectural Managemenet- en evolving field. Engineering.

Construction and Architectural Management, v.6,n.2, p. 188-196 .December/2001.

EMMITT,,S , OTTER,A.. Managing design with the effective use of communication media: the relationship between design dialogues and design team meetings. CIB WORLD BUILDING CONGRESS PROCEEDINGS,2007, Cape Town, South Africa,2007.pp 1072-1079.

EVGENIOU,T., CARTWRIGHT Barriers to Information Management. European Management Journal, Volume 23, N³, 2005. pp 293-299. 
FABRICIO, M.M.; MELHADO, S.B.. A importância do estabelecimento de parcerias construtora-projetistas para a qualidade na construção de edifícios. ANAIS DO VII ENCONTRO NACIONAL DE TECNOLOGIAS DO AMBIENTE CONSTRUÍDO. QUALIDADE NO PROCESSO CONSTRUTIVO,1998, Florianópolis, SC, NPC/ECV/CTC/UFSC, v.2, pp. 453-9.

FABRÍCIO,M.M.,BAÍA,J.,MELHADO,S.B. A brief reflection in the improvement of the design process efficiency in Brazilian building. $7^{\text {th }}$ ANNUAL CONFERENCE GROUP FOR LEAN CONSTRUCTION,1999. University of California, Berkeley,CA, USA. Proceedings IGLC- iglc.net. pp 345-356.

FABRÍCIO,M.M.,BAÍA,J.,MELHADO,S.B.. Estudo do Fluxo de Projetos : Cooperação Sequencial x Colaboração Simultânea. CONGRESSO LATINOAMERICANO DE TECNOLOGIA E GESTÃO DA PRODUÇÃO DE EDIFÍCIOS: Soluções para o terceiro milênio.1998, São Paulo. Escola Politécnica, USP. 10p.

FABRÍCIO,M.M.,BAÍA,J.,MELHADO,S.B.. Formalização e implantação de procedimentos de projeto de gestão da qualidade nos escritórios de arquitetura. ANAIS DO SEMINÁRIO INTERNACIONAL NUTAU, Faculdade de Arquitetura e Urbanismo, USP, 2000.9p.

FABRÍCIO,M.M.,MELHADO,S.B.. Fatores de Competitividade e a Engenharia Simultânea na Construção de Edifícios. IV CONGRESSO BRASILEIRO DE GESTÃO E DESENVOLVIMENTO DE PRODUTOS - Gramado, RS, Brasil, 6 a 8 de outubro de 2003. 9p.

FABRÍCIO,M.M.,SILVA,F.B.,CARDOSO,F.F.. Análise da articulação entre serviços de engenharia e projetos e as estratégias de produção das empresas construtoras de edifícios. CONGRESSO LATINO-AMERICANO DE TECNOLOGIA E GESTÃO DA PRODUÇÃO DE EDIFÍCIOS: soluções para o terceiro milênio.1998, São Paulo. Escola Politécnica, USP.1998,b. v2, p.559-562.

FAISSAL, R. et al.. Atração e Seleção de Pessoas. $8^{\circ}$ Edição. Rio de Janeiro. Editora FGV,2005. 160p.

FERREIRA, V.C.P. et al.. Modelos de Gestão. $1^{\circ}$ Edição. Rio de Janeiro. Editora FGV,2005. 188p.

FISCHER, A..Gestão por Competências. $4^{\circ}$ Edição. São Paulo . Editora Gente, 2001. 130p.

FLEURY, M.T. et al. As pessoas na organização. $1^{\circ}$ Edição. São Paulo . Editora Gente, 2002. 306p.

FOSSATI, M., NAZÁRIO, R.C., ROMAN, H.R.. Uma metodologia para implantação de sistemas de gestão da qualidade em escritórios de projetos. ANAIS DO III WORKSHOP BRASILEIRO DE GESTÃO DO PROCESSO DE PROJETO NA CONSTRUÇÃO DE EDIFÍCIOS, 2003. 5p. 
FRANCO, L.S., AGOPYAN, V.. Implementação da Racionalização Construtiva na fase de projeto. Boletim Técnico da Escola Politécnica da USP - BT/PCC/94, 1993. $23 \mathrm{p}$.

FRANCO, M.A.S.. Pedagogia da Pesquisa- Ação. Educação e pesquisa, São Paulo, v.31,n.3, p. 483 - 502, set./ dez 2005 .

GITMAN,L.J.. Princípios de Administração Financeira $7^{\circ} E$ dição. São Paulo Editora Harbra Ltda.,2002.781p.

GLOBERSON,S.. Impact of various work-breakdowns structures on project conceptualization. International Journal of Project Management, Volume 12, $\mathrm{N}^{\circ} 3$, 1994. pp 165-171.

GREENWOOD, D.,MILLER,B., A re- examination of the relationship between action research and human subjects review process. Action Research, Sage Publicatiosn, London, v.4(1),2006. p. $117-128$.

GRILLO, L.M. et al... Implementação de gestão da qualidade em empresas de projeto ANAIS DO III WORKSHOP BRASILEIRO DE GESTÃO DO PROCESSO DE PROJETO NA CONSTRUÇÃO DE EDIFÍCIOS, 2001. 5p.

GRILO, L.M. et al.. Análise da Implementação de gestão da qualidade em empresas de projeto. SIMPÓSIO BRASILEIRO DE GESTÃO DA QUALIDADE E ORGANIZAÇÂO DO TRABALHO,2001, Fortaleza, UFC - UNIFOR. 14p.

GRUPTA,U. G.., CAPEN, M.. An empirical investigation of the contribution of IS to manufatcturing productivity. Information \& Management $N^{\circ} 31,1996$. pp 227233.

HAX,A,MAJLUF,N.. Corporate Strategic Tasks. European Management Journal, Volume 12, $N^{\circ} 4,1994$. pp 366-381.

HEINECK,L.F.M. Segmentação dos projetos de edificações para o seu planejamento, coordenação e controle. ANAIS DO XI ENCONTRO NACIONAL DE TECNOLOGIAS DO AMBIENTE CONSTRUÍDO. A CONSTRUÇÃO DO FUTURO,2006, Florianópolis, SC. 10 p.

II Workshop Nacional Gestão do Processo de Projeto na Construção de Edifícios, 2., 2002, Porto Alegre. Anais..., Porto Alegre: PUC-RS, 2002. CD-ROM

III Workshop Nacional Gestão do Processo de Projeto na Construção de Edifícios, 3., 2003, Belo Horizonte. Anais..., Belo Horizonte: UFMG, 2003. CD-ROM

IV Workshop Brasileiro de Gestão do Processo de Projeto na Construção de Edifícios, 2004, Rio de Janeiro. Anais... , Rio de Janeiro: UFRJ, 2004. CD-ROM

IX ENCONTRO NACIONAL DE TECNOLOGIA DO AMBIENTE CONSTRUÍDO: Cooperação \& responsabilidade social (ENTAC 2002), 9., 2002, Foz do Iguaçu. Anais... ,Foz do lguaçu:ANTAC , 2002. CD-ROM 
JACK, S., HYMAN, J., OSBORN, F.. Small entrepreneurial ventures culture, change and impact on HRM: A critical review. Human Resource Management Review, N¹6, 2006. pp 456-466.

JACOSKI,C.A.. Peculiaridades do fluxo de informações em pequenos escritórios de projetos de edificações. ANAIS DO V WORKSHOP BRASILEIRO DE GESTÃO DO PROCESSO DE PROJETO NA CONSTRUÇÃO DE EDIFÍCIOS, 2005. 6p.

JOBIM,M.M.. Programas de Gestão da Qualidade em escritórios de projeto : Situação no Estado do Rio Grande do Sul. ANAIS DO I WORKSHOP BRASILEIRO DE GESTÃO DO PROCESSO DE PROJETO NA CONSTRUÇÃO DE EDIFÍCIOS,2001. 4 p.

KERZNER, H.. Gestão de Projetos: as melhores práticas. $2{ }^{\circ}$ Edição. Porto Alegre : Editora Bookman, 2006.821p.

KOTLER,P.. Administração de Marketing. $12^{\circ}$ Edição. São Paulo Pearson Prentice Hall,2006. 750p.

LACOMBE,F.. Recursos Humanos. Princípios e Tendências. $1^{\circ}$ Edição. São Paulo : Editora Saraiva.,2005. 420p.

LAUCHE,K.. Job Design for good design practice. Design Studies Volume 26, N 2, 2005. pp 191-213.

LAVILLE, CHRISTIAN \& DIONNE, J. A.. Construção do Saber. Manual de metodologia da pesquisa em ciências humanas - $1^{\circ}$ edição / Belo Horizonte, 1999. Editora UFMG. 340p.

LEIDTKA,J.. Strategic Planning as a Contributor to Strategic Change: A

Generative Model European Management Journal, Volume 18, N², 2000. pp 195206.

LEVY,M., POWELL,P.. Information system strategy for small and medium sized enterprises : an organisational perspective Journal of Strategic Information System $N^{\circ}$ 9, 2000. pp 63-84.

LIMA, M.I. . Ocupações Emergentes. Setor de Construção Civil. Brasilia: Senai, 2005 (Série Estudos Setoriais do SENAI).

LONGENECKER, J.G.,MOORE,C.W.,PETTY,W.J.. Administração de pequenas Empresas. Ênfase na Gerência Empresarial. $1^{\circ}$ Edição. São Paulo Pearson Education do Brasil Ltda,2004. 868p.

LOPEZ, J.M.A.. Perspespectivas para o mercado imobiliário Conjuntura da Construção, AnoV, N², pp 9-11,2007.

LOVELOCKI, C.H.. Services Marketing. $1^{\circ}$ Edição. São Paulo . Englewood Cliffs : Prentice-Hall,1991. 526p. 
LUCIANO,E.L et al.. Proposta de um conjunto de diretrizes para melhorar a compreensão dos processos de um projeto. ANAIS DO XI ENCONTRO NACIONAL DE TECNOLOGIAS DO AMBIENTE CONSTRUÍDO. A CONSTRUÇÃO DO FUTURO,2006, Florianópolis, SC.

MACÊDO, I.I. et al.. Aspectos Comportamentais da Gestão de Pessoas. $8^{\circ}$ Edição. Rio de Janeiro. Editora FGV,2006. 148p.

MAEDA, E. H. Avaliação da gestão em empresas de projeto arquitetônico no segmento do mercado imobiliário na cidade de São Paulo, 2006. Monografia (MBA) - Escola Politécnica, Universidade de São Paulo. São Paulo, 2006. 145p.

MANUAIS DE ESCOPO DE PROJETO. Manual de Escopo para Coordenação de Projetos, Versão 1.1. . Disponível em: http://www.manuaisdeescopo.com.br . Acesso em 20, Out.2007.

MANUAIS DE ESCOPO DE PROJETO. Manual de Escopo Projetos e Serviços de Ar Condicionado e Ventilação Mecânica, Versão 1.0. Disponível em: http://www.manuaisdeescopo.com.br . Acesso em 20, Out.2007.

MANUAIS DE ESCOPO DE PROJETO. Manual de Escopo Projetos e Serviços Instalações Prediais - Elétrica, Versão 1.0. . Disponível em:

http://www.manuaisdeescopo.com.br . Acesso em 20, Out.2007.

MANUAIS DE ESCOPO DE PROJETO. Manual de Escopo Projetos e Serviços Instalações Prediais - Hidráulica, Versão 1.0. . Disponível em: http://www.manuaisdeescopo.com.br . Acesso em 20, Out.2007.

MANUAIS DE ESCOPO DE PROJETO. Manual de Escopo Projetos e Serviços de Arquitetura, Versão 1.0. . Disponível em: http://www.manuaisdeescopo.com.br . Acesso em 20, Out.2007.

MANUAIS DE ESCOPO DE PROJETO. Manual de Escopo Projetos e Serviços de Automação e Segurança, Versão 1.0. .Disponível em:

http://www.manuaisdeescopo.com.br . Acesso em 20, Out.2007.

MANZIONE,L., MELHADO, SB.. Why is design delivery always behind schadule? A critical review of the design planning techniques adopted for Real Estate projects in São Paulo - Brazil. CIB WORLD BUILDING CONGRESS,2007, Cape Town, South Africa,2007.pp 850-862.

MARLOW, S.. Human resource management in smaller firms: A contradiction in terms? Human Resource Management Review, $N^{\circ} 16$, 2006. pp 467-477.

MAXIMIANO, A.C A.. Administração de Projetos. $2^{\circ}$ Edição. São Paulo. Editora Atlas, 2002.196p.

MAXIMIANO, A.C A.. Introdução à administração. $6^{\circ}$ Edição. São Paulo. Editora Atlas,2004.315p.

MAYSON, S., BARRETT, R.. The "science" and "practice" of HRM in small firms. Human Resource Management Review, N¹6, 2006. pp 447-455. 
MEIRA, L.C.C.. Um estudo exploratório em empresas baianas sobre o relacionamento entre construtoras e projetistas. ANAIS DO IV WORKSHOP BRASILEIRO DE GESTÃO DO PROCESSO DE PROJETO NA CONSTRUÇÃO DE EDIFÍCIOS, 2004. 8p.

MELHADO,S. B.. Gestão, cooperação e integração para um novo modelo voltado à qualidade do processo de projeto na construção de edifícios. 2001. Tese ( Livre - Docência) - Escola Politécnica da Universidade de São Paulo . São Paulo, 2001. 235p.

MELHADO,S. B.. Qualidade do projeto na construção de edifícios: aplicação ao caso das empresas de incorporação e construção. 1994. Tese (Doutorado) Escola Politécnica da Universidade de São Paulo . São Paulo, 1994. .294p.

MELHADO,S.B et al. Coordenação de Projetos de Edificações. $1^{\circ}$ Edição. São Paulo. Editora O Nome da Rosa,2005.

MELHADO,S.B et al. Escopo de Serviços para Coordenação de Projetos. ANAIS DO IV WORKSHOP BRASILEIRO DE GESTÃO DO PROCESSSO DE PROJETO NA CONSTRUÇÃO DE EDIFÍCIOS, 2004. 7p.

MELHADO,S.B. et al.. Coordenação de Projetos de Edificações. $1^{\circ}$ Edição. São Paulo. Editora O Nome da Rosa,2005. 78p.

MELHADO,S.B.. Qualificação das empresas de projeto de arquitetura. ANAIS DO I WORKSHOP BRASILEIRO DE GESTÃO DO PROCESSO DE PROJETO NA CONSTRUÇÃO DE EDIFÍCIOS, 2001. 5p.

MELHADO,S.B.. Uma nova solução para a certificação de sistemas de gestão da qualidade em empresas de projeto ANAIS DO III WORKSHOP BRASILEIRO DE GESTÃO DO PROCESSO DE PROJETO NA CONSTRUÇÃO DE EDIFÍCIOS, 2003. $5 p$.

MENEZES, A.A.C., LOPES, R.A., AMORIM, S.R.L.. Melhoria do processo de projeto de escritório de arquitetura - estudo de caso com ênfase na gestão de recursos humanos. ANAIS DO III WORKSHOP BRASILEIRO DE GESTÃO DO PROCESSO DE PROJETO NA CONSTRUÇÃO DE EDIFÍCIOS, 2003. 7p.

MEREDITH,J.R., MANTEL JR., S.J.. Administração de Projetos. Uma abordagem Gerencial. $4{ }^{\circ}$ Edição. Rio de Janeiro. LTC - Livros Técnicos e Científicos Editora S.A., 2003. 425p.

MILLER,B., GREENWOOD, D., EIKELAND, O.. Strategies for addressing ethical concerns in action research . Action Research, Sage Publicatiosn, London, v.4 (1), 2006 . pp. $129-131$.

MINTZBERG,H.. Criando Organizações Eficazes. Estruturas em cinco configurações. $2^{\circ}$ Edição. São Paulo. Editora Atlas,2003. 304p.

NOBRE,J.A.P.,BARROS NETO,J.P.. Proposição de melhorias no processo de desenvolvimento de produto da construção habitacional mediante à captação das informações de clientes. ANAIS DO XI ENCONTRO NACIONAL DE 
TECNOLOGIAS DO AMBIENTE CONSTRUÍDO. A CONSTRUÇÃO DO FUTURO,2006, Florianópolis, SC. 8p.

NOBRE,J.P., BARROS NETO, J.P.. Análise da situação das empresas de projeto do estado do Ceará quanto à implantação de sistemas da qualidade ANAIS DO I WORKSHOP BRASILEIRO DE GESTÃO DO PROCESSO DE PROJETO NA CONSTRUÇÃO DE EDIFÍCIOS, 2001.5p.

NOGUEIRA,F.P.S, LEUSIN, S.R., HIPPERT,C.A. Gestão do processo de projeto: contribuições para a pequena empresa de projeto. ANAIS DO XI ENCONTRO NACIONAL DE TECNOLOGIAS DO AMBIENTE CONSTRUÍDO. A CONSTRUÇÃO DO FUTURO,2006, Florianópolis, SC.7p.

OGULAMA,S.,LIM,J.SAEED,K.. A dynamic model for managing civil engineering design projects. Computers and Structures, v.67,n.5, p. 401-419 .June/1995.

OLIVEIRA, D. P.R.. Estratégia Empresarial.2Edição. São Paulo. Editora Atlas,1991.392p.

OLIVEIRA, D. P.R. Estrutura Organizacional. Uma abordagem para resultados e competitividade. $1^{\circ}$ Edição. São Paulo. Editora Atlas,2006. 322p.

OLIVEIRA, D. P.R.. Planejamento Estratégico. Conceitos, Metodologias, Práticas. $13^{\circ}$ Edição. São Paulo. Editora Atlas, 1999. 298p.

OLIVEIRA, D. P.R.. Sistemas de informações gerenciais. $5^{\circ}$ Edição. São Paulo. Editora Atlas, 1998. 305p.

OLIVEIRA, D. P.R.. Sistemas, Organização \& Métodos. Uma abordagem Gerencial. $3^{\circ}$ Edição. São Paulo. Editora Atlas, 1990.487p.

OLIVEIRA, O.J.. Gestão do Processo Comercial em empresas de projeto. ANAIS DO III WORKSHOP BRASILEIRO DE GESTÃO DO PROCESSO DE PROJETO NA CONSTRUÇÃO DE EDIFÍCIOS, 2003. 7p.

OLIVEIRA,O.J.. Modelo de Gestão para pequenas empresas de projeto de edifícios. 2005-. Tese (Doutorado) - Escola Politécnica da Universidade de São Paulo . São Paulo.256p.

OLIVEIRA,O.J., MELHADO, S.B.. Sistema de avaliação de desempenho para projetos e empresas de projeto. ANAIS DO V WORKSHOP BRASILEIRO DE GESTÃO DO PROCESSO DE PROJETO NA CONSTRUÇÃO DE EDIFÍCIOS, 2005. $6 p$.

PADILHA, E.. Marketing para Engenharia, Arquitetura e Agronomia . $6^{\circ}$ Edição. Balneario Camburiu. Santa Catarina. 2006.170 p.

PALADINI, E.P. et al.. Gestão da Qualidade. Teoria e Casos. $1^{\circ}$ Edição. Rio de Janeiro. Editora Elsevier,2005.355p.

PINTO, E.P. Gestão Empresarial. Casos e Conceitos da Evolução

Organizacional $1^{\circ}$ Edição. São Paulo Editora Saraiva.,2007.256p. 
PORTER,M.E. Estratégia Competitiva. Técnicas para Análise de indústrias e da concorrência. $16^{\circ}$ Edição.Rio de Janeiro. Editora Campus,2004.362p.

PORTER,M.E. Vantagem Competitiva. Criando e sustentando um desempenho superior. $28^{\circ}$ Edição.Rio de Janeiro. Editora Campus,1989. 512p.

PRESIDÊNCIA DA REPÚBLICA . CASA CIVIL. SUBCHEFIA PARA ASSUNTOS JURÍDICOS. Lei 6.404, de 15 de dezembro de 1976. Brasília, DF . Disponível em: http://www.cnb.org.br/CNBV/leis/lei6404_consolidada.htm. Acesso em 10, Out.2007.

Produto Interno Bruto do Brasil e da Construção Civil ,: http://ww.ibge.gov.br. Acesso em 03 abril 2008.

PUBLICAÇÃO DA BOVESPA. Mercado de Capitais. Introdução. Disponível em: http://www.bovespa.com.br . Acesso em 10, Out.2007.

QUINTÃO, F.B.M.. A gestão de pessoas e a gestão do conhecimento adquirindo pepel fundamental no processo de gestão de projetos. ANAIS DO III WORKSHOP BRASILEIRO DE GESTÂO DO PROCESSO DE PROJETO NA CONSTRUÇÃO DE EDIFÍCIOS, 2003. 5p.

REA, M.B., WILSON,H. Networks, Learning and the Lifecycle. Model European Management Journal, Volume 21, $N^{\circ} 5$, 2003. pp 588-597.

RIBEIRO, J.L.S., COSTA, M.L.S.. Implantação de Sistema de Gestão da qualidade em empresas de elaboração de projetos. ANAIS DO III WORKSHOP BRASILEIRO DE GESTÃO DO PROCESSO DE PROJETO NA CONSTRUÇÃO DE EDIFÍCIOS, 2003. 5p.

ROBSON,M.A.,SARROW,P.R.S,CLEGG,C. Design engineering competencies: future requirements and predicted changes in the forthcoming decade Design Studies Volume 27, N¹, 2006. pp 99-122.

ROUNCE,G. Quality, waste and cost considerations in architectural building design management. International Journal of Project Management v.16,n.2, 1998. p. 123-127.

RYD.,N. The design brief as carrier of client information during the construction process. Design Studies, Volume 25. Issue 3. May 2004. Pages 231249

SACOMANO NETO,M., ESCRIVÃO FILHO,E., Estrutura Organizacional e equipes de trabalho: estudo da mudança organizacional em quatro grandes empresas industriais. Gestão \& Produção, Volume 7, N²,2000. pp 136-145.

SARQUIS, A.B.. Marketing para pequenas empresas : a indústria da confecção. $1^{\circ}$ Edição. São Paulo .Editora Senac,2003. 224p.

SARROS, J.C. et al.. Work Alienation and Organizational Leadership. British Journal of Management, Volume 13, 2002. pp 285-384. 
SAUER, C., WILLCOCKS,L... Establishing the business of the future The Role of Organization Architecture and Information Technologies. European Management Journal, Volume 21, $N^{\circ} 4$, 2003. pp 497-508.

SEGNINI,F.. Considerações sobre a prática profissional do arquiteto. ANAIS DO IV WORKSHOP BRASILEIRO DE GESTÃO DO PROCESSO DE PROJETO NA CONSTRUÇÃO DE EDIFÍCIOS, 2004. 6p.

SINDUSCON-SP. O emprego na construção civil cresce $15,49 \%$ até setembro. Construmail 1403. Nov. 26, 2007. Disponível em http://www.sindusconsp.com.br. Acesso em 26, Nov.2007.

SOUZA, A. L. R. ; MELHADO, S.B. . Preparação da Execução de Obras. 1. ed. SÃO PAULO: O NOME DA ROSA, 2003. v. 1. 144 p.

SOUZA, F.R. et al.. Análise da interdependência entre as ações rotineiras em uma empresa de projeto e a sua gestão: aquisição de uma ferramenta de trabalho. ANAIS DO VIII WORKSHOP BRASILEIRO DE GESTÃO DO PROCESSO DE PROJETO NA CONSTRUÇÃO DE EDIFÍCIOS, 2008. 6p.

SOUZA, F.R. et al.. Implementação do modelo de gestão para pequenas empresas de projeto. Análise da etapa de gestão financeira e gestão de recursos humanos em uma empresa de esquadrias. ANAIS DO VIII WORKSHOP BRASILEIRO DE GESTÃO DO PROCESSO DE PROJETO NA CONSTRUÇÃO DE EDIFÍCIOS, 2008. 6p

SOUZA, F.R., MELHADO, S.B.. A importância do sistema de informação para a gestão da empresa de projeto. Gestão \& Tecnologia de Projetos. V.3, № 1, 2008. PP 121-139.

SOUZA, V.L. et al.. Gestão de Desempenho. $1^{\circ}$ Edição. Rio de Janeiro. Editora FGV,2005. 152p.

SOUZA,F.R., MELHADO, S.B.. The design process research in Brazil from 1995 to 2007. CIB CONGRESS - Design Management in the architectural Engineering and Construction Sector Proceedings, São Paulo, Brasil,2008.pp 295-306.

STEINER,G.A. Strategic Planning. What every manager must know. $12^{\circ}$ Edição. Mcmillan Publishing Co,1979. 383p.

STOFFEL, I. Administração do Desempenho: metodologia gerencial de desempenho. $1^{\circ}$ Edição. Florianópolis . Editora Perspectiva, 1997. 107p.

SYCODÉS,2007. Les indicateurs d'evolution de la qualité des constrution, .Disponível em: http//www.qualiteconstrucyin.com . Acesso em 18, Nov. 2007.

TAM,C.M. Use of the internet to enhance construction: total information transfer system.. International Journal of Project Management, Volume 17, $\mathrm{N}^{\circ} 2$, 1999. pp 107-111.

THIOLLENT, M. Metodologia da Pesquisa - Ação. $13^{\circ}$ edição / São Paulo, 2004. Cortez Editora. 108 p. 
THOMPSON,A. A JR.,STRICKLAND,A J.. Strategic Management. Concept and Cases. $12^{\circ}$ Edição. New York. McGraw - Hill,2001.

TINER,W.D. Subdivision of work on construction projects. International Journal of Project Management, Volume 3, $\mathrm{N}^{\circ}$ 1,1985. pp 13-18.

TRIPP,D. Pesquisa- Ação : Uma introdução metodológica. Educação e pesquisa, São Paulo, v.31,n.3, 2005. pp. $443-466$.

TURBAN,E.,MCLEAN,E.,WETHERBE,J. Tecnologia da informação para gestão. Transformado os negócios da economia digital. $3^{\circ}$ Edição. Porto Alegre. Editora Bookman,2004.598p.

Um guia do Conjunto de Conhecimentos em gerenciamento de Projetos (Guia GUIA PMBOK (2004). Project Mangement Institute, Inc,2004

V Workshop Brasileiro de Gestão do Processo de Projeto na Construção de Edifícios, 2005, Florianópolis. Anais...,Florianópolis.: UFSC, 2005. CD-ROM.

VASCONCELLOS,E., HEMSLEY,J.R. Estrutura das Organizações. $1^{\circ}$ Edição. São Paulo : Editora da Universidade de São Paulo,1986. 208p.

VASCONCELOS, R.F.M., AMORIM, S.R.L., ARANTES, A.J.F. A gestão de escritórios de projetos de arquitetura na região do Rio de Janeiro. ANAIS DO V WORKSHOP BRASILEIRO DE GESTÃO DO PROCESSO DE PROJETO NA CONSTRUÇÃO DE EDIFÍCIOS, 2005. 6p.

VERGARA, S.C.. Gestão de pessoas. $2^{\circ}$ Edição. São Paulo : Editora Atlas S.A.,2000. 171p.

VI ENCONTRO NACIONAL DE TECNOLOGIA DO AMBIENTE CONSTRUÍDO: Qualidade e Tecnologia na Habitação (ENTAC 95), 6., 1995, Rio de Janeiro. Anais... ,Rio de Janeiro: UFRJ/ANTAC, 1995. CD-ROM

VI Workshop Brasileiro de Gestão do Processo de Projeto na Construção de Edifícios, 2006, São Paulo. Anais...,São Paulo: FAU-USP, 2006. CD-ROM.

VII ENCONTRO NACIONAL DE TECNOLOGIA DO AMBIENTE CONSTRUÍDO: Qualidade no Processo Construtivo (ENTAC 98), 7., 1998, Florianópolis. Anais... ,Florianópolis: UFSC/ANTAC, Florianópolis, 1998. CD-ROM

VII Workshop Brasileiro de Gestão do Processo de Projeto na Construção de Edifícios, 2007, Curitiba. Anais... ,Curitiba: 2007. CD-ROM.

VIII ENCONTRO NACIONAL DE TECNOLOGIA DO AMBIENTE CONSTRUÍDO: Modernidade e Sustentabilidade (ENTAC 2000), 8., 2000, Salvador. Anais... ,Salvador.: UFBA/UNEB/UEFS/ANTAC, 2000. CD-ROM

WALKER, P.A.,KAMARA,J.M. The capture and reuse of design cost information in architecture. CIB WORLD BUILDING CONGRESS PROCEEDINGS, Cape Town, South Africa,2007, pp 1037-1048. 
Workshop Nacional Gestão do Processo de Projeto na Construção de Edifícios, 1., 2001, São Carlos. Anais..., São Carlos: EESC/USP 2001. CD-ROM

X ENCONTRO NACIONAL DE TECNOLOGIA DO AMBIENTE CONSTRUÍDO:

Construção Sustentável (ENTAC 2004), 10., 2004, São Paulo. Anais... ,São Paulo: ANTAC/EPUSP, 2004. CD-ROM

XI Encontro Nacional de Tecnologia do Ambiente Construído: A construção do futuro (ENTAC 2006), 11., 2006, Florianópolis. Anais... ,Florianópolis.: ANTAC, 2006. CDROM 